
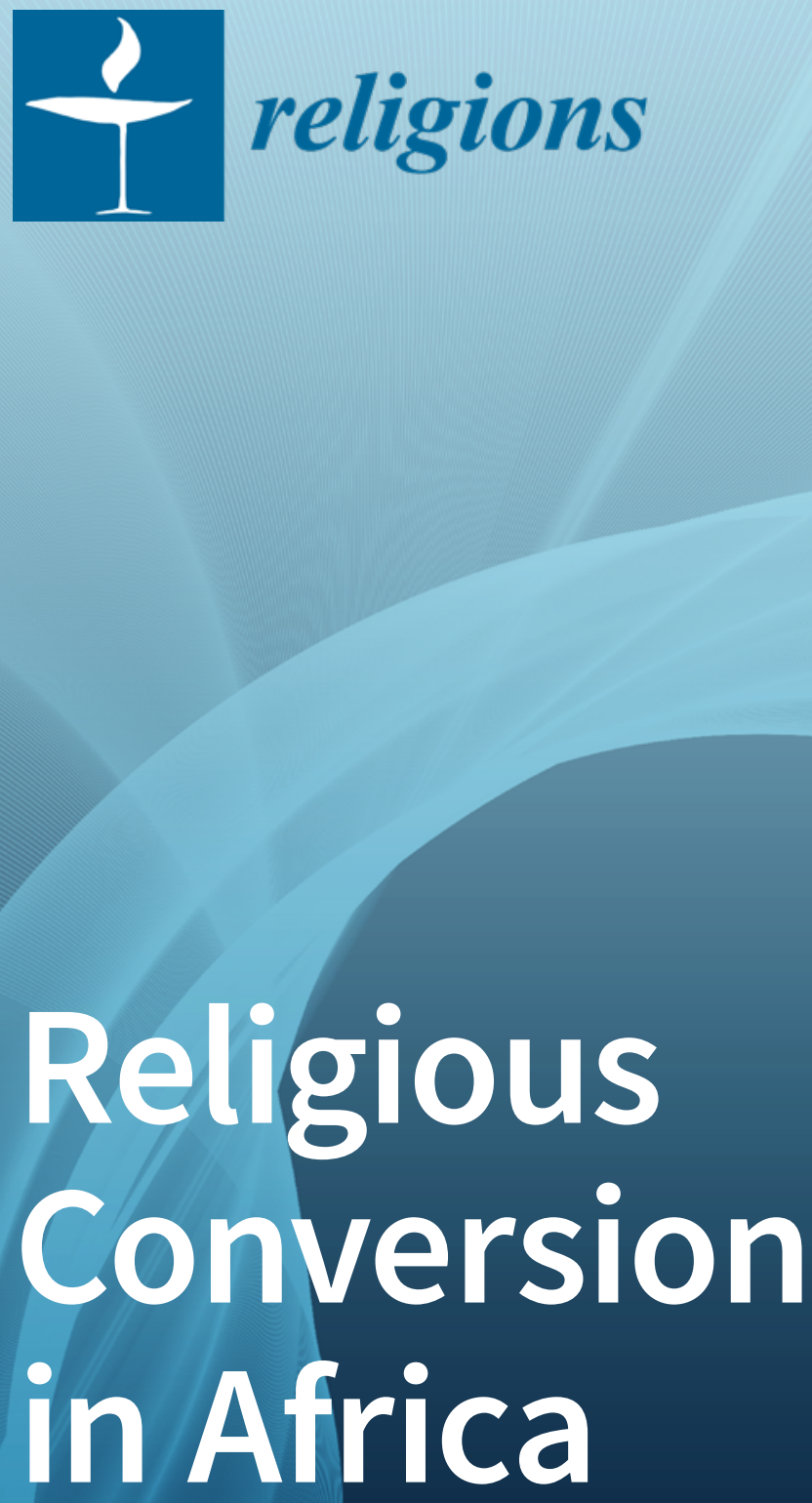

Edited by Jason Bruner and David Dmitri Hurlbut Printed Edition of the Special Issue Published in Religions 
Religious Conversion in Africa 



\section{Religious Conversion in Africa}

Editors

Jason Bruner

David Dmitri Hurlbut

MDPI $\bullet$ Basel $\bullet$ Beijing $\bullet$ Wuhan $\bullet$ Barcelona $\bullet$ Belgrade $\bullet$ Manchester $\bullet$ Tokyo $\bullet$ Cluj $\bullet$ Tianjin 
Editors

Jason Bruner

Arizona State University

USA
David Dmitri Hurlbut

Boston University

USA

Editorial Office

MDPI

St. Alban-Anlage 66

4052 Basel, Switzerland

This is a reprint of articles from the Special Issue published online in the open access journal Religions (ISSN 2077-1444) (available at: https://www.mdpi.com/journal/religions/special_issues/religious_ conversion).

For citation purposes, cite each article independently as indicated on the article page online and as indicated below:

LastName, A.A.; LastName, B.B.; LastName, C.C. Article Title. Journal Name Year, Article Number, Page Range.

ISBN 978-3-03943-034-5 (Hbk)

ISBN 978-3-03943-035-2 (PDF)

(C) 2020 by the authors. Articles in this book are Open Access and distributed under the Creative Commons Attribution (CC BY) license, which allows users to download, copy and build upon published articles, as long as the author and publisher are properly credited, which ensures maximum dissemination and a wider impact of our publications.

The book as a whole is distributed by MDPI under the terms and conditions of the Creative Commons license CC BY-NC-ND. 


\section{Contents}

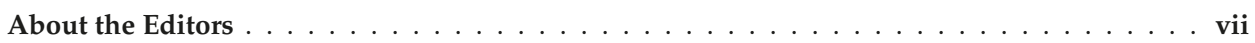

\section{Jason Bruner and David Dmitri Hurlbut}

Moving beyond Discontinuity in Religious Conversion in Africa: A Preface to the Special Issue

Reprinted from: Religions 2020, 11, 395, doi:10.3390/rel11080395 . . . . . . . . . . . . . 1

\section{Jason Bruner and David Dmitri Hurlbut}

New Approaches to 'Converts' and 'Conversion' in Africa: An Introduction to the Special Issue

Reprinted from: Religions 2020, 11, 389, doi:10.3390/rel11080389 _ . . . . . . . . . . . 5

Kimberly Marshall and Andreana Prichard

Spiritual Warfare in Circulation

Reprinted from: Religions 2020, 11, 327, doi:10.3390/rel11070327 . . . . . . . . . . . . 15

\section{Devaka Premawardhana}

Reconversion and Retrieval: Nonlinear Change in African Catholic Practice

Reprinted from: Religions 2020, 11, 353, doi:10.3390/rel11070353 . . . . . . . . . . . . . 33

\section{Shamara Wyllie Alhassan}

"We Stand for Black Livity!": Trodding the Path of Rastafari in Ghana

Reprinted from: Religions 2020, 11, 374, doi:10.3390/rel11070374 . . . . . . . . . . . . . . 47

\section{Dmitri M. Bondarenko and Andrey V. Tutorskiy}

Conversion to Orthodox Christianity in Uganda: A Hundred Years of Spiritual Encounter with Modernity, 1919-2019

Reprinted from: Religions 2020, 11, 223, doi:10.3390/rel11050223 . . . . . . . . . . . . . . 57

\section{Anna Redhair Wells}

Hagiography as Source: Gender and Conversion Narratives in The Book of the Saints of the Ethiopian Church

Reprinted from: Religions 2020, 11, 307, doi:10.3390/rel11060307 . . . . . . . . . . . . . .

\section{David Dmitri Hurlbut}

The "Conversion" of Anthony Obinna to Mormonism: Elective Affinities, Socio-Economic Factors, and Religious Change in Postcolonial Southeastern Nigeria

Reprinted from: Religions 2020, 11, 358, doi:10.3390/rel11070358

\section{Katrin Langewiesche}

Conversion as Negotiation. Converts as Actors of Civil Society

Reprinted from: Religions 2020, 11, 322, doi:10.3390/rel11070322 



\section{About the Editors}

Jason Bruner is an associate professor of Global Christianity in the School of Historical, Philosophical, and Religious Studies at Arizona State University. He is the author of Living Salvation in the East African Revival in Uganda (2017), and his articles have appeared in journals such as Material Religion, the Journal of Religion in Africa, Studies in World Christianity, and the Journal of Ecclesiastical History.

David Dmitri Hurlbut earned both his $\mathrm{PhD}$ and his MA in history from Boston University, where he was a Title VI Foreign Language and Area Studies (FLAS) fellow in Igbo. He received his BA from Lewis and Clark College in Portland, Oregon. He currently serves as the managing editor of the African Conflict and Peacebuilding Review and as a book review editor for H-Africa. He was the 2018-2019 Graduate Research Fellow in Mormon Studies at the Tanner Humanities Center, University of Utah. His scholarship has appeared in the International Journal of African Historical Studies and the Journal of Mormon History. 

Editorial

\title{
Moving beyond Discontinuity in Religious Conversion in Africa: A Preface to the Special Issue
}

\author{
Jason Bruner ${ }^{1, *}$ and David Dmitri Hurlbut ${ }^{2, *}$ \\ 1 School of Historical, Philosophical, and Religious Studies, Arizona State University, Tempe, AZ 85281, USA \\ 2 Department of History, Boston University, Boston, MA 02215, USA \\ * Correspondence: Jason.Bruner.1@asu.edu (J.B.); dhurlbut@bu.edu (D.D.H.)
}

Received: 24 July 2020; Accepted: 30 July 2020; Published: 31 July 2020

This Special Issue emerged through a conversation about how to foster new lines of analysis with respect to religious, cultural, and social change on the African continent. More to the point, we recognized that priming discontinuity in studies of "conversion" captures important dynamics with respect to certain types of Christian churches-namely, Pentecostal and charismatic ones. But what other processes of religious change have been occluded by the predominance of this line of (Christian) analysis in the literature on "conversion" in Africa?

Attending to this question is not merely theoretical but also epistemological and methodological. Whose categories, experiences, and mentalities are privileged to be deemed analytically important when it comes to shifts in religious adherence, belief, identity, tradition, and community? Furthermore, scholarly examinations of religious change are often caught in a challenging methodological bind. On the one hand, they can purport to be about an experience of inner transformation. On the other, the historian or even ethnographer often only has access to these interior states through extant written documents or the language that the person uses to convey the change or transformation. These inclinations have made studies of this phenomenon quite dependent upon the category of belief, locating "conversion" in the process of changing a person's belief, or with respect to communities defined primarily by religious belief or doctrine.

Scholars who study African Christian communities that value discontinuity in "conversion" focus on why converts seek rupture in their religious lives—a stark contrast between their past and present selves. Many studies have answered that question by pointing to the dysfunctions of postcolonial governance in Sub-Saharan Africa, combined with the challenges of "millennial capitalism". That is, there have been clear, socio-political reasons that account for why many African Christians want to make a break with the past. Though these studies have addressed what had been a lacuna in studies of African Christianity, there is much that the present interest with this form of "conversion" omits from analytical view.

This approach is deeply tied to not only Christian, but specifically Pentecostal, categories and theologies. It is often quite dependent upon verbal testimony as its foundation. It likewise tends to portray a linear development and trajectory (away from a past and towards a future), which does not always reflect the complex ways in which adherents engage with those churches. It has difficulty capturing the sensibilities of Christian traditions and communities other than charismatic and Pentecostal ones, to say nothing of communities that are not Christian, and it cannot easily account for processes by which the past is seen as a desirable resource in the present. "Conversion" in pre-colonial Africa is likewise largely out of its purview. As a result, we wanted to convene a wide range of scholars, including historians of pre-colonial, colonial, and contemporary Africa, along with anthropologists, who would be able to offer fresh arguments and reassessments of religious change pertaining to Africa. The result is comprised of fascinating analyses and interventions that offer critical, creative, and constructive analyses of religious change on the African continent from the medieval period to the present. 
We open the issue with a critical introduction to the topic of religious "conversion" in Africa. This article summarizes the concept's indebtedness to Christian categories and assumptions, and addresses the limitations of this approach with respect to religious change, belief, and practice, particularly in Sub-Saharan Africa. While acknowledging the term's biases and limitations, we also note the fact that some Africans have used (and continue to use) the term to describe their own transformations, meaning that "conversion" exists in the scholarship as both an etic and emic category.

While Andreana Pritchard and Kimberly Marshall examine charismatic Christianity in Sub-Saharan Africa, they do so with transatlantic sensibilities. They utilize two case studies to good effect in order to show unexpected religious and theological exchanges among North American (a Navajo evangelist and an Oklahoman short-term missionary, respectively) and Sub-Saharan African charismatic Christians. They muddy the issue of continuity in "conversion" by considering the realities that African charismatic ideas, beliefs, and practices have likewise come to shape American Christians' lives and spiritualities. Their work shows how being overly concerned with continuity or discontinuity in conversionary narratives can draw attention away from the ways in which these communities have created new networks of exchange.

Devaka Premawardhana offers a historiographical overview of the literature on discontinuity and Christian "conversion" before pivoting to ask a different set of questions regarding inculturation and Roman Catholicism in Sub-Saharan Africa. By contrasting a case study of an Italian Roman Catholic missionary in Mozambique with the Pentecostal theologies and communities also present in that region, Premawardhana is able to perspicaciously illumine differences in theological inclinations and processes of "inculturation" among Christian traditions. He then raises comparative questions regarding continuity and exchange among different Christian traditions in Mozambique. Through this analysis, Premawardhana demonstrates the importance of considering style with respect to religious change in a particular context.

Matters of style are central to Shamara Wyllie Alhassan's article on Rastafari women in Ghana. By "style", here, we mean two things. First, Wyllie Alhassan provides a fascinating look at what "trodding the path" means in the lives of Ghanaian women, with attention given to the importance of hair and clothing in signifying their Rastafari identity and commitments. These elements are essential to Rastafari ways of being, becoming, and "overstanding" — standing for Black livity and decolonizing one's self. In this sense, style is also about a style of scholarship and epistemology, and the inseparability of one from the other. For these reasons, Wyllie Alhassan finds the term "conversion" itself inappropriate for analyzing change among Rastafarians.

Dmitri M. Bondarenko and Andrey V. Tutorskiy's study of "conversion" among Ugandan Orthodox Christians fills in two historical lacunae at once. Orthodox Christians in Uganda have largely been overlooked in favor of Anglicans, Pentecostals, and Roman Catholics, and relatively few studies of "conversion" to Orthodoxy in Africa have been done. Their research illuminates the importance of ritual, as well as of the realities of tradition and orthopraxy being important sources of power, authority, and truth for converts. Perhaps most provocatively, Bondarenko and Tutorskiy use the concept of multiple modernities to locate the appeal of tradition as a way of being modern in contemporary East Africa.

Anna Redhair Wells' fascinating article uses a hagiographical text to examine gender and agents of religious change in medieval Ethiopia. Her analysis shows the importance of gender and family connections in patterns of conversion among Ethiopian saints, ultimately using the text to argue for an agentive space for women in medieval Ethiopian Christianity. Wells' creative re-reading of extant textual sources provides a model for thinking about processes of "conversion" in Africa prior to the colonial and modern periods.

David Dmitri Hurlbut's article on "conversion" to Mormonism in postcolonial southeastern Nigeria explores the issues surrounding the reliability of sources produced post-conversion and the value of contextualizing such testimony. While discussions about cultural continuity in processes of religious change have fallen largely out of fashion, Hurlbut shows that cultural endurance continues 
to shape processes of religious change outside of a Pentecostal context. His article locates important sources of continuity with respect to practice, rituals, and community.

Katrin Langewiesche's study of Ahmadi "conversion" in West Africa and France highlights the importance of transnational relationships and networks of migration and belonging in relation to changes in religious identity and adherence. Langweische's article shows that "conversion" is a social process, sustained by practices whereby an individual comes to be seen and understood as a "convert".

The contributors to this Special Issue on "Religious Conversion in Africa" do not make an argument for a singular new method. The interventions we make are not specific to a discipline. Rather, our hope is that these articles collectively indicate the pluriform ways in which Africans have engaged with religious and social change across time and geography, encouraging others to attend to these contexts with fresh insight and care.

(C) 2020 by the authors. Licensee MDPI, Basel, Switzerland. This article is an open access article distributed under the terms and conditions of the Creative Commons Attribution (CC BY) license (http://creativecommons.org/licenses/by/4.0/). 

Article

\title{
New Approaches to 'Converts' and 'Conversion' in Africa: An Introduction to the Special Issue
}

\author{
Jason Bruner ${ }^{1, *}$ and David Dmitri Hurlbut ${ }^{2, *}$ \\ 1 School of Historical, Philosophical, and Religious Studies, Arizona State University, Tempe, AZ 85281, USA \\ 2 Department of History, Boston University, Boston, MA 02215, USA \\ * Correspondence: Jason.Bruner.1@asu.edu (J.B.); dhurlbut@bu.edu (D.D.H.)
}

Received: 26 June 2020; Accepted: 27 July 2020; Published: 29 July 2020

\begin{abstract}
It is our goal in this special issue on "Religious Conversion in Africa" to examine the limitations of a long-standing bias toward Christianity with respect to the study of "conversion." Furthermore, we want to use this issue to prime other scholarly approaches to cultural change on the continent, beginning as early as the medieval period, including the colonial and early postcolonial eras, and extending to the contemporary. There are several reasons for making these interventions. One is the emergence of the anthropology of Christianity as a scholarly literature and sub-discipline. This literature has often focused on issues of religious change in relation to its own predilection for charismatic and Pentecostal expressions of Christianity and the distinct characteristics of cultural discontinuity within those communities. Another reason for this special issue on religious "conversion" in Africa is the relative lack of studies that engage with religious change beyond Pentecostal, charismatic, and evangelical Protestant contexts. As such, studies on the "conversion" of Ahmadi in West Africa, medieval Ethiopian women, Mormons in twentieth-century southeastern Nigeria, and Orthodox Christians in Uganda are included, as is a fascinating case of what it means to "trod the path" of Rastafari in Ghana. Taken together, these contributions suggest new and important paths forward with respect to "conversion," including critiquing and perhaps even discarding the term in certain contexts. Ultimately, we want these articles to illuminate the many ways that Africans across the continent have engaged (and continue to engage) with beliefs, practices, ideas, and communities-including the changes they make in their own lives and in the lives of those communities.
\end{abstract}

Keywords: conversion; Africa; anthropology of Christianity; history; Africana religions; historiography

\section{Introduction}

Scholarly examinations of religious "conversion" have long held a bias toward Christianity. The historian A.D. Nock even posited that it was early Christians who invented the concept, which he defined as "the reorientation of the soul of an individual, his deliberate turning from indifference or from an earlier form of piety to another, a turning which implies consciousness that a great change is involved, that the old was wrong and the new is right" (Nock 1933, p. 7). Likewise, William James (1985, p. 157) was fascinated by the ways in which evangelical "conversions" allowed "a self hitherto divided, and consciously wrong, inferior and unhappy, [to become] unified and consciously right, superior and happy." With these approaches to the subject setting the terms, "conversion" entered scholarly discourse while also carrying with it Christian—and especially evangelical Protestant-assumptions about what mattered most: the transformation of the soul brought on by a changed set of interior dispositions and beliefs.

It is our goal in this special issue on "Religious Conversion in Africa" to examine the limitations of this long-standing assumption with respect to "conversion." Furthermore, we want to use this issue 
to prime other scholarly approaches to cultural change on the continent, beginning as early as the medieval period, including the colonial and early postcolonial eras, and extending to the contemporary. There are several reasons for making these interventions. One is the emergence of the anthropology of Christianity as a scholarly literature and sub-discipline. This literature has often focused on issues of religious change in relation to its own predilection for charismatic and Pentecostal expressions of Christianity and the distinct characteristics of cultural discontinuity within those communities. Kimberly Marshall, Andreana Prichard, and Devaka Premawardhana even suggest in this special issue that the theme of cultural rupture in studies of "conversion" has become the heart of that literature. Another reason for this special issue on religious "conversion" in Africa is the relative lack of studies that engage with religious change beyond Pentecostal, charismatic, and evangelical Protestant contexts. As such, studies on the "conversion" of Ahmadi in West Africa, medieval Ethiopian women, Mormons in twentieth-century southeastern Nigeria, and Orthodox Christians in Uganda are included, as is a fascinating case of what it means to "trod the path" of Rastafari in Ghana.

Taken together, we think these contributions suggest new and important paths forward with respect to "conversion," including critiquing and perhaps even discarding the term in certain contexts. Since many of the articles in this special issue raise questions about the concept of conversion and its use in history, we have chosen in this introduction to put the term in quotation marks. In doing so, we want to draw attention to the ways that the term is contextually relevant and useful, including how it has been employed by scholars as well as the communities examined in this special issue's articles. Ultimately, we want these articles to illuminate the many ways that Africans across the continent have engaged (and continue to engage) with beliefs, practices, ideas, and communities-including the changes they make in their own lives and in the lives of those communities. The directions of their engagements cannot be summarized simply. While there are African Christians who would testify to the fact that they have "made a break with the past," there are many other Africans whose lives do not fit that analytic. What they have made of their lives, communities, and religious traditions is likewise fully worthy of scholarly attention. In short, the contributions to this special issue underscore that "religious change" cannot frequently be defined as a shift from one frame of mind to another. Depending on where and when historians and anthropologists are looking, the process of religious change could involve the adoption of a new religious moniker, the embrace of new rituals, the abandonment of certain social customs, or the formation of new relationships and interpersonal bonds, or some combination of visible cultural and/or social transformations. By thinking critically about the definition of "religious change" in future research, we can loosen the stranglehold that Protestant missionaries and their ideas have had on the literature on religious conversion in Africa.

\section{Continuity and Discontinuity in Religious "Conversion"}

The question of "conversion," and especially of "conversion" to Christianity, has been dominated in recent years by a preoccupation with the problem of continuity and discontinuity. This problem is often defined in relationship to individuals: What elements of an adherent's life and identity are taken to be evidence of a "break with the past," or of continuity with it?

With respect to Christianity and the African continent, the issue of continuity first emerged from questions among colonial-era missionaries about the sincerity of Africans' intentions to become Christians. Missionaries from all denominational backgrounds shared concerns about "mixing" indigenous cultural practices with Christianity. However, Protestant missionaries in particular needed to determine that "converts" had made a sufficient break with "paganism" or "heathenism" so that they truly had become "new creatures in Christ Jesus" (Keane 2007). Additionally, missionaries could be suspicious of adherents' use of the new tools and technologies that missionaries supplied-medicine, literacy, trans-regional economics-in order to make what they felt like were illegitimate hybrid forms of the faith, thereby becoming "nominal" Christians. Some missionaries also embraced these "new" elements as beneficial to their ultimate goal of drawing Africans in the Christian fold, an inclination 
especially seen in missionary support of the development of industrial education in the 1920s and 1930s across Sub-Saharan Africa (Barnes 2017; Peterson 2011).

Even from the early twentieth century, many missionaries had to come to terms with the fact that "conversion" often looked less than ideal. Africans did things with their new faith, the Bible, and religious practices that went beyond what missionaries had intended. Bengt Sundkler, for instance, observed that "in these [African indigenous] churches, one could be able to see what the African Christian, when left to himself, regarded as important and relevant in Christian faith and in the Christian church" (Sundkler 1948, p. 17). Colonialists often combined their concerns regarding the supposed purity of adherents' faith with an interest in the maintenance of colonial order. The potential violence to European settlers posed by indigenous movements, such as Maji Maji in German East Africa or Mau Mau in Kenya, illuminate the perennial threat posed by what was perceived as a primitivist spiritually inflected paganism (Anderson 2005; Lemarchand 2013; Mahone 2006). Colonial officials across the continent policed Christian movements for worrisome signs that they might foment rebellion. The suppression of the Harrist movement in Congo is one example, and the British suspicion of the East African Revival and the Spirit Movement in southeastern Nigeria are others. Colonial officials and missionaries thereby sought out methods to determine whether popular movements were sufficiently "Christian" - that is, that such movements severed "paganism" from "modernity" and "politics" from "religion" (Bruner 2019; Ranger 1986). If one were concerned about discontinuity in these instances, the "past" could be as capacious or selective as the one doing the defining of what needed to be left behind.

Historians and anthropologists explored these issues by focusing upon the unique contextualization or indigenization of the faith that grew out of missionary encounters in the colonial era (Barrett 1968; Walls 1996). While most scholars of these "new" expressions or forms of Christianity understood them to be in continuity with Christianity's (European) forms and institutions, they also frequently highlighted the agency of Africans and their propensity to translate things anew, creating new debates and insights in their novel configurations of ancient teachings and institutions. The attention given to prophetic healing movements and African Indigenous Churches in the mid-late twentieth century is clear evidence of this approach. Many of these scholars, such as Bengt Sundkler or Harold Turner whose scholarship was informed by their faith commitments, as Adrian Hastings has pointed out, approached their research with the desire to "make amends for the past failings in mission relationships with independent churches" (Hastings 2000, p. 33). For this reason, they located a great degree of continuity not only with historical Christianity but also with African cultures and beliefs, or what became glossed as "African Traditional Religion" (Peterson and Walhof 2002). In this sense, Christianity was often described as a vehicle of survivals, enabling some practices, structures, and beliefs to endure amidst the disintegrative onslaught of Euro-Western colonialism and postcolonialism (Daneel 1970; Dube 1999; Kibira 1974, chp. 1).

Sociological models for religious change were similarly premised upon some kind of continuity in "conversion," while likewise reifying the religious as the site of personal transformation or change of identity, affiliation, or adherence. Writing in the mid-twentieth century, Robin Horton maintained that "conversion" to monotheistic "world religions" such as Islam and Christianity would result from Africans' recognition of the insufficiency of their localized practices and spirits in accounting for larger geo-political realities produced by trade, travel, technological innovation, and literacy. In seeking to account for the broader realities of this larger world, he argued, they would rationally move their religious conceptions from a local microcosm to a transnational macrocosm, with a supreme, monotheistic deity overseeing a more expansive world. "Conversion," in Horton's radically functional analysis, is rational, explanatory, and, in a sense, inevitable, with any distinction between Islam and Christianity ultimately mattering little (Horton 1975a, 1975b).

Stage models of "conversion" implied a kind of continuity, seeing changes occur in typical steps, allowing for a comparative accounting of religious change across and within cultures. By their nature, these models applied etic categories to the lives of those changing their religious adherence, belief, 
and practice. Even if adherents understood these changes as sudden, mysteriously providential, or even as a radical break with their previous life, this scholarship emphasized progression, gradual movement, and predictability (Rambo and Farhadian 1999, pp. 23-34). In doing so, it borrows from the deeply seated assumptions about culture and time that are imbedded within the disciplines of sociology and anthropology themselves—the sense that, in Joel Robbins' words, "culture comes from yesterday, is reproduced today, and shapes tomorrow" (Robbins 2007, p. 10). Yet many of these same converts might describe their Christian faith as having "made a complete break with the past" (Meyer 1998). In short, where anthropologists, social scientists, and historians might see continuity, converts themselves describe an undeniable discontinuity.

The matter has taken on new importance in light of the attention given to charismatic and Pentecostal expressions of Christianity within the interrelated sub-disciplines of World Christianity, the anthropology of Christianity, and of religion in Africa more generally. Led by scholars such as Joel Robbins (2007), Matthew Engelke (2007), and Birgit Meyer (1998), many have argued that earlier social scientific preoccupations with tracing elements of continuity blinded scholars to the fundamentally important ways in which adherents understand themselves and positioned themselves with a different understanding of time. The matter, of course, is not simply about self-understanding, but also in the ways that converts go about organizing their lives, homes, and communities in light of that shift in their beliefs, practices, and self-understanding (Haynes 2015; Marshall 2009). In these areas, historians and anthropologists would do well to consider Robbins' observation that "Christianity represents time as a dimension in which radical change is possible," looking both back towards its "break" with Judaism in the early centuries, as well as eschatological break in the anticipated millennium (Robbins 2007, p. 10). Such attention to contrasts in time, discourse, and beliefs of Christians has allowed these scholars to distinguish themselves within their own disciplinary traditions-to make their own break with their discipline's past, emphasizing rupture as a characteristic of this Christian conception of time and culture.

These foundational concerns within the anthropology of Christianity have shaped studies of religious change in an outsized way. Scholars have focused upon a certain style of Pentecostalism, particularly the kind that is transnationally connected, with huge congregations that continue to grow (e.g., Van de Kamp 2016). These churches likewise seem to support the earlier predictions from scholars writing within the discipline of World Christianity, that Christianity is young, dynamic, charismatic, and expanding. Here Pentecostalism becomes a synecdoche for all of Christianity's supposedly global, almost inevitable, growth that scholars of world Christianity have been projecting (Robert 2000). Largely excluded from this narrative are non-Pentecostals and even, as Devaka Premawardhana's article shows in this special issue, Pentecostalism in those places where it has not thrived in the ways it has in Seoul, Lagos, or Rio de Janeiro (Cabrita and Maxwell 2017). Additionally, not every Christian tradition or denomination is predicated upon the radicality of the break with one's past. Furthermore, instances of cultural continuity inevitably exist side by side with instances of cultural rupture, a phenomenon observed by David Dmitri Hurlbut in his article here, as well as by Charlotte Walker-Said (2018, p. 24) in her study of Catholicism in colonial French Cameroon. The continuity/discontinuity paradigm is a false choice that oversimplifies a complex cultural reality.

More to the point, the emphasis upon discontinuity in matters of "conversion" can also mean that non-Christian people, communities, and traditions have a difficult time fitting into the Christianized discourse. Novelty, innovation, and a search for a sense of authenticity-or even an alternate path of continuity - can all occasion change that results in conversion or changing one's religious identity or adherence. Still, Pentecostalism has become so predominant in some parts of Africa that other Christian denominations (such as Methodists, Presbyterians, and Catholics) are becoming "Pentecostalized" in response, incorporating healing and all-night prayer services; but so too have other religious communities and traditions used Pentecostalism's methods for their own ends (Adogame 2011). Muslim and Hindu proselytization in West Africa, for example, often takes on characteristics borrowed from the earlier, successful outreach of Pentecostals (Peel 2016, chp. 10). They do not, however, 
seem to have taken the idea that "conversion" necessitates a stark break with one's past. For some Hindu communities in Ghana outreach looks Pentecostal, but the message is one of deep continuity, as preachers argue that India is the prehistoric cradle of African civilization. In this sense, the style is one response to a Pentecostal demonization of the African past (Wuaku 2013). As Shamara Wyllie-Alhassan's article in this issue demonstrates, the term "conversion" does not necessarily capture the dynamics of change in religious communities that are not Christian. In these examples, one could say that religious change that results in not simply a turn or break towards the new, but a return to a sense of the old remains relevant to the lives of many people outside of the Pentecostal and evangelical context. The article from Dmitri M. Bondarkeno and Andrey V. Tutorskiy in this special issue indicates that this is the case for "converts" to Orthodoxy in Uganda, suggesting that ancient tradition, ritual, and orthopraxy can be compelling reasons for people to change their religious adherence.

While our analytical framework is influenced by our shared engagement with Christianity in Africa, the literature on Islam in Africa also problematizes the Protestant idea that conversion constitutes a shift from frame of mind to another, or of one strictly bound "religion" to another. As Adeline Masquelier summarizes in her perceptive study of Muslim women in Niger:

[By] embracing Islam, people did not abandon previous beliefs so much as they adopted new practices that visibly marked them as Muslim. Conversion to Islam is too often assumed to be a total and uncompromising process, a sweeping rejection of the "old." The equation of "belief" with homogenous, systemized, and neatly bounded cosmology led scholars to neglect the conversation between Islam and what is conventionally categorized as "traditional" religion. (Masquelier 2009, p. 61)

As Barbara Cooper's study of Hausa Muslims and evangelical Christians in Maradi, Niger demonstrates, the process of religious change primarily involved changes to daily behaviors, such as the choice to cease "praying with other Muslims," to stop brewing "beer in order to call a gayya (a party called to work together in the host's fields in exchange for beer), or even "to reject the offer of a titled office that would have entailed making sacrifices" (Cooper 2006, pp. 289-390). In addition, evangelical Christians made Christianity "legible to Muslims" by embracing "Allah" as the moniker for God in their scriptural translations and by baptizing polygynous men into the church (Cooper 2006, pp. 125, 391). Similarly, Janet McIntosh's study of Giriama and Swahili culture in Kenya show that linguistic choices, which can be made to reify religious and ethnic identity, can also indicate a spiritually and religiously pluralistic context, suggesting that essentialisms that have to come shape life since the colonial era are "hardly secure, given the constant flow of languages and religions between peoples" (McIntosh 2005, p. 168). In these studies of Islam in Niger and Kenya, the colonial era is seen to be contextually paramount in creating the conditions in which essentialized discourses of religion and ethnicity took hold (McIntosh 2004). In short, the literature on Islam in Africa further highlights the need to rethink how historians and anthropologists engage with religious conversion.

\section{Problematizing "Conversion" in African History}

The spread of Christianity on the African continent-in antiquity for northern and eastern Africa, and in the colonial era for much of Sub-Saharan Africa-meant not only the expansion of Christian texts, practices, beliefs, and communities, but also of Christianized understandings of change. It was the introduction of Christianity in many parts of the African continent that spread the notion of conversion - that is, as an individual's consent to change or adopt their affiliation with a community based upon its doctrines, rituals, and moral teachings. These assumptions, however, could also (even unintentionally) foster the expansion of more rigid understandings and expressions of Islam (Masquelier 2009). However, it also provided assumptions about the possibility and desirability of progress and the need for individual transformation. The notion of "conversion" - particularly in the modern period - most often implied the movement of an individual from one bounded religion with a set of doctrines and practices, to another, as seen in Nock's formulation. In the case of much of Sub-Saharan 
Africa, however, this precondition can be very difficult to establish. In short, one is often hard-pressed to say that there was a "religion" from which new African Christians "converted." Many Sub-Saharan African languages did not seem to have a vernacular term that readily correlated to "religion" in the sense it had developed over the late nineteenth century in Europe and North America. In East Africa, for example, the Swahili term dini predated the arrival of Christian missionaries, and came closest to how European missionaries used "religion." In Buganda (now south-central Uganda), dini was used to translate what the new European missionaries brought, but even this was not a vernacular Luganda term. As Paul Landau has convincingly argued, the concept of indigenous "religion" is "an artefact of the Christian encounter with non-Christians" (Landau 1999, p. 11). One might even go so far as to say that the very concept of "African Traditional Religion" was developed in part to facilitate this conceptual distinction between what needed to be converted "from" and what needed to be converted "to" (Peterson 2002).

English-speaking evangelical missionaries often brought literature that they used to help them determine whether they were witnessing "genuine conversions". In this sense, texts like the American evangelist Charles Finney's Revivals of Religion have had global histories and legacies. This dynamic illuminates the challenge that the concept of "conversion," including especially that form of "conversion" prized among evangelical Christians, was not simply an invention. Rather, the concept had historical consequences, as new Christian adherents needed to learn how to be seen as "converts"—often on missionaries' terms-if they were to endure in the new world of the colonial mission station. This distinction is relevant beyond colonial Christian missions. As Katrin Langewiesche shows so clearly with respect to Ahmadi in West Africa and France in this special issue, conversion is "a matter of social issues not personal belief."

Missionaries, both Catholic and Protestant, recognized that there were other contextual factors at play in facilitating religious change. Schools and clinics, along with new foods and agricultural techniques carried different kinds of appeal to potential converts, and missions frequently drew initially from marginal and disaffected populations, those in search of protection, and those on the political fringes and looking for new sources of authority. However, the social patterns of adherence to Christianity in the colonial period in Sub-Saharan Africa defy simplistic narratives. In some places, the movement might be said to be from the "bottom" up, if one is examining social class. In others, such as Benin, Buganda, Warri, and Kongo, Christian missionaries first attracted (or tried to attract) elites in the royal court (Thornton 1984; Ryder 1960, 1961; Hansen 1984).

What is undeniably clear, particularly after Jean and John Comaroff's monumental work (Comaroff and Comaroff 1991) on Nonconformist Christianity's encounter with the Tswana, is that "Christianity" — as a reified category — could not exist outside of the orbit of social, political, and material change in colonial sub-Saharan Africa. Such assemblages had been observed earlier by both scholars and missionaries. Robin Horton (1975a, 1975b), for example, explained conversion to so-called "world religions" like Islam and Christianity by developing a model whereby Africans would seek new explanations for the expanding socio-economic world in which they found themselves living as a result of colonial encounters with Europeans. If Horton's model seems inclined toward the elite, one must be careful to not too quickly assume that common folk had no interest in accounting for the changes-sometimes violent and profoundly disruptive changes-that were occurring in their lives (Feierman 1990; White 2000). This is equally true for the colonial and postcolonial periods, for, as Uchenna Okeja observes, "the subalterns, who are mostly at the center of postcolonial discourses, indeed can and do speak!" (Okeja 2013, p. 109). Horton's analysis has gained a kind of traction in the way scholars have often described the appeal of Pentecostalism. It is true that, generally speaking, Sub-Saharan Africa has seen the rapid growth of charismatic and Pentecostal churches since the 1970s. The apparent appeal of Pentecostal, or neo-Pentecostal churches and their narratives of conversionary discontinuity has often been read against the backdrop not of "African culture" or "African tradition" tout court, but rather against the more immediate backdrop of violent, destructive, and dysfunctional postcolonial histories. 
For many Africans, Christianity (or, at least Christian communities, beliefs, and practices) was a means to move forward, and the forward-looking modernity that accompanied the expansion of millennial capitalism seemed to fit with the broader ethos of change that was inculcated within these Christian communities. As Dmitri M. Bondarenko and Andrey V. Tutorskiy's article on Ugandan Orthodoxy shows, however, the Christian past can also be viewed as a repository of ritual resources that need not be understood as antithetical to a modern present. Similarly, as Shamara Wyllie Alhassan explains in this issue, Christianity can also be understood to be part of the social, metaphysical, and structural problems from which Africans want respite. In these senses, there could be said to be multiple modernities with which Africans are engaging. This multiplicity is itself a critique of Horton's model, which seemed to not care to differentiate between Christianity and Islam, let alone contrasting expressions of those traditions. Yet, the diverse communities within these traditions help constitute, produce, and reproduce African modernities in a plurality of ways.

This multiplicity matters to the analyses included in this special issue. The challenges here are both conceptual and historiographical. Scholars should not assume that those who did undergo catechesis or baptism did so only out of material or political calculation since, in many cases, one either has insufficient or non-existent sources to investigate these issues. Additionally, even when one has access to these sources, they are frequently later historical sources that were composed after "conversion," as David Dmitri Hurlbut's article in this special issue demonstrates. These sources frame the adherents' "conversion" experience through the lens of their new religious identity, thereby compromising the reliability of the narrative from a historical perspective. Furthermore, "conversion" was frequently a matter of interpersonal relationships. As Anna Wells' contribution shows, familial bonds, especially the bond between mother and daughter, were a defining factor in the "conversion" of women in The Book of the Saints of the Ethiopian Church. While Well's article focuses its conclusions on the premodern period, Andreana Prichard (2017) has confirmed the continuing importance of affect in religious "conversion" in the colonial and postcolonial periods. In her article with Kimberly Marshall in this issue, Pritchard also highlights the transnational ties among Pentecostal Christians between the United States of America and West and East Africa as a way of illuminating the exchanges that have helped to constitute global Pentecostal belonging and beliefs. We also should pay closer attention to the ways that people narrate their lives with respect to religious and observable processes of cultural change. Shamara Wyllie Alhassan, for instance, demonstrates in her special issue contribution that the Rastafari themselves do not speak of "conversion." Alhassan joins many of the contributors in this issue in challenging the idea that religious change is about belief, or about leaving and joining communities that are clearly bounded by doctrine.

Ultimately, it may never be possible to abandon the terms "conversion" and "convert" entirely since adherents themselves embrace the terms, which are then unavoidable when studying religious change from an emic perspective. Nevertheless, historians and anthropologists need to think more critically about how we are deploying these terms. The importance of the subjective, interior dimensions of religious experience and conversion will endure for religious adherents and missionaries, but the notion of replacing an old set of "pagan" beliefs with a new set of Christian or Islamic beliefs is often tendentious from a scholarly perspective, especially when complicated by scant or incomplete historical records. As the contributors to this special collectively show, religious "conversion" is a process that frequently has more to do with interpersonal and familial bonds, ritual, elective affinities, and socio-economic factors than it does with belief. The term conversion without any scare quotes does not reflect this complex reality.

Author Contributions: Conceptualization, J.B. and D.D.H.; formal Analysis, J.B. and D.D.H.; writing-original Draft Preparation, J.B. and D.D.H.; writing - review \& editing, J.B. and D.D.H. Both authors have read and agreed to the published version of the manuscript.

Funding: This research received no external funding.

Conflicts of Interest: The authors declare no conflicts of interest. 


\section{References}

Adogame, Afeosemime U., ed. 2011. Who Is Afraid of the Holy Ghost? Pentecostalism and Globalization in Africa and Beyond. Trenton: Africa World Press.

Anderson, David. 2005. Histories of the Hanged: The Dirty War in Kenya and the End of Empire. New York: W.W. Norton \& Company.

Barnes, Andrew. 2017. Global Christianity and the Black Atlantic: Tuskegee, Colonialism, and the Shaping of African Industrial Education. Waco: Baylor University Press.

Barrett, David. 1968. Schism and Renewal in Africa: An Analysis of Six Thousand Contemporary Religious Movements. Oxford: Oxford University Press.

Bruner, Jason. 2019. Religion and Politics in the East African Revival. International Bulletin of Mission Research 43: 311-19. [CrossRef]

Cabrita, Joel, and David Maxwell. 2017. Relocating World Christianity. In Relocating World Christianity: Interdisciplinary Studies in Universal and Local Expressions of the Christian Faith. Edited by Joel Cabrita, David Maxwell and Emma Wild-Wood. Leiden: Brill, pp. 1-44.

Comaroff, Jean, and John Comaroff. 1991. Of Revelation and Revolution: Christianity, Colonialism, and Consciousness in South Africa. Chicago: Chicago University Press.

Cooper, Barbara M. 2006. Evangelical Christians in the Muslim Sahel. Bloomington: Indiana University Press.

Daneel, Marthinus. 1970. Zionism and Faith-Healing in Rhodesia: Aspects of African Independent Churches. The Hague: Mouton.

Dube, Musa. 1999. Consuming a Colonial Cultural Bomb: Translating Badimo into 'Demons' in the Setswana Bible (Matthew 8.28-34;15.22; 10.8). Journal for the Study of the New Testament 21: 33-58. [CrossRef]

Engelke, Matthew. 2007. A Problem of Presence: Beyond Scripture in an African Church. Berkeley: University of California Press.

Feierman, Steven. 1990. Peasant Intellectuals: Anthropology and History in Tanzania. Madison: University of Wisconsin Press.

Hansen, Holger Bernt. 1984. Mission, Church and State in a Colonial Setting: Uganda 1890-1925. London: Heinemann.

Hastings, Adrian. 2000. African Christian Studies, 1967-1999: Reflections of an Editor. Journal of Religion in Africa 30: 30-44. [CrossRef]

Haynes, Naomi. 2015. 'Zambia Shall be Saved!' Prosperity Politics in a Self-Proclaimed Christian Nation. Nova Religio 19: 5-24. [CrossRef]

Horton, Robin. 1975a. On the Rationality of Conversion: Part 1. Africa 45: 219-35. [CrossRef]

Horton, Robin. 1975b. On the Rationality of Conversion: Part 2. Africa 45: 373-99. [CrossRef]

James, Williams. 1985. The Varieties of Religious Experience. Cambridge: Harvard University Press.

Keane, Webb. 2007. Christian Moderns: Freedom and Fetish in the Mission Encounter. Berkeley: University of California Press.

Kibira, Josiah. 1974. Church, Clan, and the World. Uppsala: Gleerup.

Landau, Paul. 1999. "Religion" and Crhsitian Conversion in Arican History: A New Model. Journal of Religious History 23: 8-30. [CrossRef]

Lemarchand, René. 2013. Forgotten Genocides: Oblivion, Denial, and Memory. Philadelphia: University of Pennsylvania Press.

Mahone, Sloane. 2006. The Psychology of Rebellion: Colonial Medical Responses to Dissent in British East Africa. Journal of African History 47: 241-58. [CrossRef]

Marshall, Ruth. 2009. Political Spiritualities: The Pentecostal Revolution in Nigeria. Chicago: University of Chicago Press.

Masquelier, Adeline. 2009. Women and Islamic Revival in a West African Town. Bloomington: Indiana University Press.

McIntosh, Janet. 2004. Reluctant Muslims: Embodied Hegemony and Moral Resistance in a Giriama Spirit Possession Complex. Journal of the Royal Anthropological Institute 10: 91-112. [CrossRef]

McIntosh, Janet. 2005. Baptismal Essentialisms: Giriama Code Choice and the Reification of Ethnoreligious Boundaries. Journal of Linguistic Anthropology 15: 151-71. [CrossRef]

Meyer, Birgit. 1998. "Make a Complete Break with the Past." Memory and Post-Colonial Modernity in Ghanaian Pentecostalist Discourse. Journal of Religion in Africa 28: 316-49. 
Nock, Arthur D. 1933. Conversion: The Old and the New in Religion from Alexander the Great to Augustine of Hippo. Oxford: Clarendon Press.

Okeja, Uchenna. 2013. Postcolonial Discourses and the Equivocation of Expertise. Philosophia Africana 15: 107-16. [CrossRef]

Peel, John David Yeadon. 2016. Christianity, Islam, and Orisa Religion: Three Traditions in Comparison and Interaction. Oakland: University of California Press.

Peterson, Derek R. 2002. Gambing with God: Rethinking Religion in Colonial Central Kenya. In The Invention of Religion: Rethinking Belief in Politics and History. Edited by Derek R. Peterson and Darren Walhof. New Brunswick: Rutgers University Press, pp. 37-58.

Peterson, Derek. 2011. Conversion and the Alignments of Colonial Culture. Social Sciences and Missions 24: 207-32. [CrossRef]

Peterson, Derek, and Darren R. Walhof, eds. 2002. The Invention of Religion: Rethinking Belief in Politics and History. New Brunswick: Rutgers University Press.

Prichard, Andreana C. 2017. Sisters in Spirit: Christianity, Affect, and Community Building in East Africa, 1860-1970. East Lansing: Michigan State University Press.

Rambo, Lewis R., and Charles. E. Farhadian. 1999. Converting: Stages of Religious Change. In Religious Conversion: Contemporary Practices and Controversies. Edited by Lamb Christopher and M. Darroll Bryant. London: Cassell, pp. 23-34.

Ranger, Terence O. 1986. Religious Movements and Politics in Sub-Saharan Africa. African Studies Review 29: 1-69. [CrossRef]

Robbins, Joel. 2007. Continuity Thinking and the Problem of Christian Culture: Belief, Time and the Anthropology of Chrisitanity. Current Anthropology 48: 5-38. [CrossRef]

Robert, Dana. 2000. Shifting Southward: Global Christianity since 1945. International Bulletin of Missionary Research 24: 50-58. [CrossRef]

Ryder, Alan F. C. 1960. Missionary Activity in the Kingdom of Warri to the Early Nineteenth Century. Journal of the Historical Society of Nigeria 2: 1-26.

Ryder, Alan F. C. 1961. The Benin Missions. Journal of the Historical Society of Nigeria 2: 231-59.

Sundkler, Bengt. 1948. Bantu Prophets in South Africa. London: Lutterworth Press.

Thornton, John. 1984. The Development of an African Catholic Church in the Kingdom of Kongo. Journal of African History 25: 147-67. [CrossRef]

Van de Kamp, Linda. 2016. Violent Conversion: Brazilian Pentecostalism and Urban Women in Mozambique. Woodbridge: James Currey.

Walker-Said, Charlotte. 2018. Faith, Power, and Family: Christianity and Social Change in French Cameroon. Woodbridge: James Currey.

Walls, Andrew. 1996. The Missionary Movement in Christian History: Studies in the Transmission of Faith. Maryknoll: Orbis Books.

White, Luise. 2000. Speaking with Vampires: Rumor and History in Colonial Africa. Berkeley: University of California Press.

Wuaku, Albert Kafui. 2013. Hindu Gods in West Africa: Ghanaian Devotees of Shiva and Krishna. Leiden: Brill.

(C) 2020 by the authors. Licensee MDPI, Basel, Switzerland. This article is an open access article distributed under the terms and conditions of the Creative Commons Attribution (CC BY) license (http://creativecommons.org/licenses/by/4.0/). 

Article

\title{
Spiritual Warfare in Circulation
}

\author{
Kimberly Marshall ${ }^{1}$ and Andreana Prichard ${ }^{2, *}$ \\ 1 Department of Anthropology, University of Oklahoma, 455 W. Lindsey St., Norman, OK 73069, USA; \\ kjm@ou.edu \\ 2 Honors College, University of Oklahoma, 1300 Asp Ave., Norman, OK 73019, USA \\ * Correspondence: aprichard@ou.edu
}

Received: 29 May 2020; Accepted: 18 June 2020; Published: 2 July 2020

\begin{abstract}
Without a doubt, an overenthusiastic focus on rupture, as a way of coping with neoliberal trauma, has shaped the conversation about recent religious change in Africa. Yet, rupture remains at the heart of what African charismatics understand themselves to be doing. In this paper, we attempt to nuance this conversation about rupture in religious change in Africa by discussing that various ontologies of spiritual warfare are encountered, made legible, reframed, and redeployed, through direct interactions between Africans and Americans in the context of missionization. We illustrate the patterns of these reciprocal flows through two case studies drawn from our larger research projects. One study illustrates the case of Matthew Durham, a young American missionary who, when accused of sexually assaulting children at an orphanage in Kenya, adopted the spiritual counsel of a Kenyan missionary that the reason he had no memory of the attacks was because of his possession by a demon. Another study discusses the example of a Navajo pastor who applied charismatic techniques of spiritual warfare when under metaphysical threat during a mission trip to Benin, but simultaneously focused on building ontologically protective social networks with Africans. Americans and Africans involved in the flows of global Pentecostalism are equally sympathetic to charismatic renewal. However, the reality of threats presented by malicious spiritual forces are echoed and amplified through concrete missionary networks that belie traditional North-South flows.
\end{abstract}

Keywords: Pentecostal/charismatic missionization; spiritual warfare; networks

\section{Introduction}

The threat of "Voodoo Spirits" is often deployed within American popular culture as a stereotype of African religions, reflecting both a deep misunderstanding of actual African religious worlds and a chasm of disconnection between African and Judeo-Christian ontologies that has allowed these stereotypes to spiral out of control. Yet, Christianity is changing, both in America and in Africa, with the meteoric rise of Pentecostal/charismatic Christianity. The contemporary structures of interaction have brought together ontologies of the beings who inhabit the invisible world around us and have "translated" (Meyer 1999) threatening non-human actors in their wake. Spiritual "warfare" has become the common vocabulary through which Pentecostal/charismatic Christian actors across both continents have begun to reorganize the vast differences between traditional ontologies of threats posed by non-human actors into a common vocabulary of threat and battle. Despite this, how this ontological circulation across continents happens on the ground is still somewhat opaque.

For instance, the argument that his accusers had practiced "some sort of pseudo-tribal psychological voodoo" on him was part of the defense counsel's arguments in the 2014 case of the United States of America vs. Matthew Lane Durham. Durham, a young American missionary from Edmond, Oklahoma, was on trial for suspicion of sexually assaulting children at an orphanage in Kenya. Durham claimed that he was possessed by a demon who made him variously commit or forget he had committed sexual assault against the children. Government prosecutors saw this claim as evidence of "irrational 
behavior" (Western District, Document 26, p. 9) ${ }^{1}$, arguing that he therefore was not competent to stand trial. The defense counsel, on the other hand, refused to rule out the possibility that demon actors may have affected Durham, implicitly arguing that (in Oklahoma, at least) an ontological view that admits the real threat of demons is not tantamount to insanity. What both sides missed is the way in which Durham's demon-filled ontologies were developed in his direct interactions with African charismatic Christianity (Doc 26, p. 5).

Voodoo was also on the lips of Wallace Begay, an independent Navajo pastor who is part of the Pentecostal/charismatic Oodlání (believers) movement among Native Americans in Southwestern USA. Through his networks of reciprocal contacts with other independent charismatic pastors (both Native and non-Native), Begay traveled to Benin, West Africa, for a short-term mission trip during February 2008. Through the meticulous recording of his thoughts in a daily audio journal, Begay reveals that his assumptions about the ontological threats posed by "voodoo priests" holding "voodoo fetishes" were paired with his equally strong assumptions about the prophylactic power of reciprocal relationships. With a detailed catalog of the bolo ties and other gifts that he bestows upon various "kings", Begay demonstrates a deeply Native American practice of establishing reciprocal relationships through material goods, reinforcing the networked nature of the Pentecostal/charismatic movement that has fueled its spread across both Africa and Native North America. The building of reciprocal relationships in Africa is ontologically significant because it also reveals a deeply Navajo strategy of promoting positive relationships in a chain that bridges human and non-human worlds, in order to protect against a supernatural threat.

In this article, we push the boundaries of analysis by focusing on ontologies of spiritual warfare as they are circulated within the network-based nature of contemporary global Pentecostalism. Through these two case studies-the Durham case and the case of a Navajo missionary pastor traveling in Benin-we explore several concrete instances of contact. Our analysis traces how these ontologies came into contact with one another and how they came to circulate in broader global flows. This approach to the study of spiritual warfare does several things: first, it situates spiritual warfare not just within local and localized contexts, but within the context of conversations between localities. Second, this approach allows us to see how mutually constitutive and reinforcing the local ontologies of spiritual warfare actually are, and to highlight the ways in which they are made legible in the context of global flows and networks. Third, this approach sidesteps the debate about rupture and continuity in the Pentecostal/charismatic literature, within which the prominence of demons and other malicious non-human actors is used by both sides: both as evidence of Christianity's localization and as evidence of Christianity's assimilative properties-depending on the theoretical preference of the author. Our approach privileges instead the value of interconnected networks as a motivating factor in peoples' decision to engage with spiritual warfare and in shaping how they understand it. Ultimately, we argue that this flow of spiritual warfare ideas and practice across linked networks has the potential to seriously challenge our long-held assumptions about the Christian mission, from North to South or from core to periphery.

\section{Spiritual Warfare}

Spiritual warfare is a collection of rituals, practices and discourses that aim to do battle with (typically) invisible supernatural threats. It is undergirded by an ontological orientation that sees nefarious non-human actors as able to "intervene" in the affairs of humans, and in spiritual warfare as the "Christian version" of taking a stand against those forces. ${ }^{2}$ According to the volume Pentecostalism and Witchcraft: Spiritual Warfare in Africa and Melanesia, while Pentecostal/charismatic Christianity has been

1 United States of America, Plaintiff, v. Matthew Lane Durham, Defendant. Case No. M-14-271-STE, United States District Court for the Western District of Oklahoma. Hereafter (Western District ... ).

2 For more details on the development and spread of spiritual warfare theologies and approaches to missionization since the 1970s, see Ruth Marshall (2016, pp. 98-100). 
adopted in a vast range of cultures around the globe, the handling of witchcraft and demons through processes of spiritual warfare may well be the "crux of Pentecostal universalism" (Rio et al. 2017, p. 8). In the contexts of recent Pentecostal/charismatic spread, spiritual warfare describes the ways in which converts combat the ontological threats posed by traditionally understood non-human actors (spirits/ancestors/witches), translating them into a generic category of "demonic" (Meyer 1999). ${ }^{3}$ Furthermore, participants in global Pentecostal/charismatic Christianity have circulated a common set of beliefs and practices for combating these demonic forces: a weaponized form of Christianity, typically a kind of focused and long-duration prayer (R. Marshall 2016).

As a conventional practice of engaging with the non-human realm, spiritual warfare can be deployed by Pentecostal/charismatic Christians in many contexts. According to ethnographers working within the anthropology of Christianity, spiritual warfare is deployed against the ills of modernity, such as when Guatemalan Pentecostals pray against drug trafficking ( $\mathrm{O}^{\prime} \mathrm{Neill}$ 2015), or by Ghanaian Pentecostal immigrants against the territorial spirits of an amoral secular Europe (Krause 2015), or against the demonic potential of modern technologies like cell phones and the Internet (Pype 2017). However, this warfare can also be deployed against traditionally understood threats, such as witches, territorial spirits, and ancestral spirits. For example, Daswani describes a visiting Nigerian pastor who led a group of Pentecostal Ghanaians in prayer over handfuls of sand in order to "sever ties to their ancestral homelands" and defeat the "witchcraft spirits" of that land (Daswani 2013, p. 467). Aboriginal converts in Australia have adopted spiritual warfare techniques, in order to protect them from sacred landscapes which can no longer be harnessed for beneficent magic because of knowledge lost to settler colonialism, and have now become ontologically threatening (Ono 2012). Moreover, among Navajo Pentecostal converts in the US Southwest, spiritual warfare in the form of "shooting" invisible arrows is used to protect converts from traditional non-human threats like shape-changing witches called skinwalkers (Marshall 2016).

Understanding how spiritual warfare operates on the ground is important, we argue, because it remains primarily motivating for converts. The drive to protect the self and loved ones from unseen threats has been, and remains, one of the major motivations driving religious conversion and fueling the Pentecostal/charismatic movement over other (less spiritually-warfare inclined) forms of Christianity. Furthermore, when tactics of spiritual warfare are deployed against the non-human actors of traditional ontologies, the practice itself becomes relevant to discussions about the continued relevance of rupture as an analytical category for understanding the spread of global Pentecostalism.

\subsection{Spiritual Warfare in Continuity and Rupture}

Some of the literature on spiritual warfare has focused on the way in which spiritual warfare has been localized by Pentecostal/charismatic converts, arguing that even religious change as dramatic as that represented by Pentecostal/charismatic Christianity is fundamentally localized in practice (Amster 2009; Chua 2012). Some have emphasized the ease with which Pentecostal/charismatic Christianity becomes incorporated into the traditional threatening ontologies of the new contexts where it is adopted (Bastian 1993; Manning 1980). Therefore, they maintain, spiritual warfare represents,

3 Historians of missionization in Africa have been critical of the terms "conversion" and "converts", arguing that issues such as translation, local epistemologies, and inherited beliefs about another world at the time of Africans' first encounters with Christian missionaries and ideologies mediated between missionary intention and African interpretation. Africans did not always (could not always) see Christianity as a discrete category of human activity and could therefore not "convert" to it, leaving something else behind. Instead, they drew on both Christian values and preexisting ideas without distinguishing between them and with no sense of contradiction (Landau 1999, 2000; Larson 1997; Comaroff and Comaroff 1991, 1997). The terms "convert" and "conversion" thus often appear in scare quotes to signal this ideological critique. Scare quotes have not been employed here because the actors below practiced Christianity before they employed tools of P/c Christianity or came to identify as Pentecostal/charismatic Christians and are assumed to have generally understood Christianity and/or religion as a discrete sphere of human activity that one could convert to or from in the conventional sense. The contemporary missions with which this article is concerned don't generally see themselves as converting the "heathen" or "untouched" to Christianity, but with converting already-practicing Christians to a new form of practice. 
at its core, a type of continuity. This line of argument has been taken up by respected historians of Pentecostalism, especially in regard to Africa, arguing that many of the worship styles of Pentecostalism have African roots (Hollenweger 1997), with others taking a troubling stance that Pentecostalism better connects to a kind of "primal spirituality" that is apparent in less-modern cultures (Cox 1995).

Although distancing themselves from the colonialist implications of these lines of argument about why Pentecostal/charismatic Christianity has localized so easily in the global south, anthropologists have remained fond of continuity as a framework for explaining the movement's global spread. As scholars who tend to focus on the staying power of culture as a fundamental interpretive framework, not unimportantly because it foregrounds the agency of converts, the overlay of local meanings about spiritual warfare seems a particularly appealing way to explain what diverse cultures have "done with" Christianity. Insightful in-depth studies of local contexts of conversion have focused on explaining the ways that globally circulating discourses of spiritual warfare are localized and contextualized within culturally specific frameworks. Chua, for example, analyzes the continuity of adat gawai rituals in Malaysia (Chua 2012, p. 521). Stritecky (2001) focuses on the way spiritual warfare is localized in the Solomon Islands, and Jorgensen (2014) argues that spiritual warfare is practiced in Papua New Guinea, as a way of claiming enfranchisement into uranium gas development. Kiernan (1992) argued that Zulu Zionist churches in South Africa are largely adopting the practices and authority of non-Christian Zulu diviners, and Laugrand and Oosten (2010) have argued a similar continuity between Inuit Shamans and Pentecostal Inuit preachers. Authors in this vein argue that spiritual warfare is a Pentecostal/charismatic practice so malleable that it can be localized within drastically different cultural contexts.

The analysis of the localization of spiritual warfare, however, can also overstate the case for continuity. As José Casanova pointed out nearly two decades ago, Pentecostal/charismatic Christianity is "an uprooted local culture engaged in spiritual warfare with its own roots ... " (Casanova 2001, pp. 437-38), and that our focus on the localization of spiritual warfare may take our focus away from the projects of change that converts intend. As a leading anthropologist of Christianity, Joel Robbins has stated that these "perils" of "continuity thinking" may conflict with the reality of communities who openly declare their intention to participate in projects of change (Robbins 2003).

Part of understanding the argument for the discontinuity of spiritual warfare is in recognizing the fundamental translations of demonic power that are taking place in Pentecostal/charismatic contexts. These communities aren't just waging spiritual warfare against Christian demons, they are morally reframing the entire unseen universe (traditional and new, secular and sacred, physical and invisible) into blanket ontologies of good and evil. ${ }^{4}$ Post-colonial church missions became much more interested in incorporating existing religious ontologies in order to bring "the occult and evil within reach of church practices" (Rio et al. 2017, p. 13; See also R. Marshall 2016; Macdonald 2015). So, while Pentecostal/charismatic Christians may continue to recognize that traditional healers have power, they do not attempt to forge continuity with them (Casanova 2001). In fact, their dichotomized ontologies often group practices and non-human actors previously understood as positive (such as healers or ancestors) into the category of demonically powered. In Tanzania, for example, Lindhardt reports that the born-again population sees themselves as engaged in constant spiritual warfare against the forces of the devil, and "the players on the Devil's team include humans and spiritual beings associated with 'African tradition' such as witches, traditional healers ... and ancestral spirits as well as spirits associated with Islam” (Lindhardt 2015, p. 148). A similar eliding of traditionally understood non-human actors happens throughout the global Pentecostal world, including in the highlands of

4 Some scholars, such as Peter Geschiere, have introduced the idea that the categories of non-human actors involved in spiritual warfare are themselves worthy of study, since many of them (including the concept of witchcraft and sorcery) are always translations of local notions, yet have often become appropriated by the local populations and translated into local terms (Geschiere 2017, p. 286). Marshall (2015) attempts something of this kind of translation exercise with Navajo non-human actors, as translated through Pentecostal Navajo discourse. 
Bolivia (Harris 2006, p. 54) and among Navajos in Native North America (Marshall 2016). According to these authors, while a cosmological universe containing many kinds of enlivened non-human actors may remain stable through Pentecostal/charismatic transformation, the practices of interacting with them (such as spiritual warfare) certainly represent rupture.

So vexed has this debate between continuity and rupture become that it comprises what several scholars have called the central theme of the anthropology of Christianity (Lampe 2010; Coleman and Hackett 2015, pp. 14-16), and discussing the nuances of the completeness of the "break with the past" (Meyer 1999) has become key to leading contemporary studies within the anthropology of Christianity (Engelke 2010). In trying to understand how the practice of spiritual warfare itself shapes the cosmological imaginary of the contemporary Pentecostal/charismatic movement, some scholars have discussed the ethical frameworks involved (Daswani 2013) or the time/space assumptions implicit (R. Marshall 2009). Others have discussed the way that a focus on language and expressive culture can mediate these inherent contradictions (Meyer 2004; Engelke 2010; Marshall 2016). In this article, we attempt to write our way out of this debate between continuity and rupture, by focusing on the networked circulation of spiritual warfare.

\subsection{Spiritual Warfare in Circulation}

Scholars have long recognized the egalitarian structure of Pentecostal/charismatic networks. Largely, this analysis has been focused on the utility of the network structure for evangelization. Within Pentecostal/charismatic Christianity, the fact that recent converts are quickly transformed into evangelists themselves has been widely cited as one major factor explaining the movement's rapid spread (Annis 1987; Blumhofer 1993; Bowen 1996; Chesnut 1997; Kamsteeg 1998; Lehmann 2001; Synan 1997; Stoll 1990; Martin 1990). Incorporated into this analysis has been a focus on media and the ways in which media production and circulation is used to unify Pentecostal/charismatic believers across the globe. Coleman (2000) and Hackett (1998), in particular, have conducted in-depth studies of the media products and language ideologies in circulation along Pentecostal/charismatic networks. The way that the interconnected media networks affect the musical landscapes of global Pentecostalism has been another focus for many scholars (Ingalls and Yong 2015; Butler 2019). Some have studied the political implications of these interconnected networks for statehood, in places like Nigeria (R. Marshall 2009; Obadare 2018), Brazil (Helgen 2020) and Guatemala (Garrard-Burnett 1998). A close attention to Pentecostal/charismatic networks, and the people that move along them, is fundamental to understanding the contemporary global Pentecostal/charismatic movement. From a theological perspective, the relationality of the Pentecostal/charismatic movement can be overlooked, because scholars and theologians understand it as continuing along the fundamental individually-centered Protestant salvationist theological logics of rational Protestantism. ${ }^{5}$ Yet, as Robbins summarizes, "P/c Christians are a far-flung network of people held together by their publications and other media productions, conferences, revival meetings, and constant travel" (Robbins 2004, p. 125). ${ }^{6}$ We maintain that the role of these interconnected networks in circulating ontologies like spiritual warfare has been largely overlooked.?

5 A noted exception is Omri Elisha's work on the importance of relationality in Evangelical bible study groups in Tennessee (Elisha 2015).

6 In this, networks of $\mathrm{P} / \mathrm{c}$ Christians resemble pre- and early-colonial religious, spiritual, and clan-based networks spanning the African continent and, later, the diaspora. Drawing on Neil Kodesh's work about "therapeutic networks" between discontiguous clan lands, Prichard makes a similar case for the networks of affective spirituality that knit together a religious community in eastern Africa in the latter half of the nineteenth century (Kodesh 2008; Prichard 2017).

7 Ruth Marshall (2016) has gestured toward the importance of the circulation of these ontologies. She says, "The complex processes of globalization at work in the elaboration and circulation of this fairly heterodox interpretation of apostolic spiritual warfare provides a fascinating insight into the dynamic and almost haphazard way in which charismatic Christianity grows and spread. Rather than a specific doctrine or doctrines, one finds a bricolage, a living, moving corpus of ideas, scriptural interpretations, images, discourses and techniques developed and circulating across a range of personal, institutional 
In this article, we push the boundaries of analysis by interpreting Pentecostal/charismatic spiritual warfare practices through the network-based nature of contemporary global Pentecostalism. We explore specific instances of culture contact between various iterations of spiritual warfare discourses. The first is a case which links Kenya and Oklahoma in 2014; the second case links Benin and the Navajo Nation in 2008. These examples illustrate that, while ontologies of spiritual warfare produce rupture at the local level, these discourses can only truly be understood when contextualized as global flows along Pentecostal/charismatic networks. And, to be sure, these examples can also be seen as in the tradition of much longer-standing networks, those of trans-Atlantic creativity, exchange, change, improvisation, and violence that date back to the early days of the slave trade (Thornton 1998; Matory 2005; Miller 2012; Sweet 2011). Yet, they are also equally part of new global flows, those of Pentecostal/charismatic Christianity that connect South America, Africa, and Oceania in unique ways.

\section{Matthew Durham's Demon}

On 13 June 2014, Kenyan staff at the Upendo Children's Home in peri-urban Nairobi accused one of the American missionaries serving at the center of sexually assaulting children under his care. Matthew Lane Durham, then nineteen years of age, was, at the time of the accusations, on his fourth short-term mission trip with the faith-based NGO Upendo Kids International. The NGO is based in the Oklahoma City commuter suburb of Edmond, but serves orphans and other vulnerable children in the founder's hometown of Juja, Kenya. Initially, Durham strenuously denied all charges of wrongdoing. He protested that he could not recall even a single incident that might possibly have been construed as inappropriate, much less as sexual molestation. Trying to sort through the morass, Eunice Menja, the mission's founder, made a suggestion: while Menja did not believe Durham himself "would have ever been capable of hurting the children", she did think that he might "have been possessed by an evil spirit or demon" that caused him to molest them. Possession, she told Durham, would explain why he could not "remember his acts" (Western District, Document 71; Western District, Document 63, p. 7).

In the hours and days after staffers made the first round of accusations against Durham, the young man himself adopted Menja's explanation of the events: that he had been possessed by a demon who had made him commit illicit sexual acts against children, and then forget them. While still in Kenya, Durham began to seek out ways to have the demon exorcised. Namely, he reached out to his friend and fellow missionary, Hannah Nichols. Durham once described Nichols, who had previously spent time at Upendo but who was not on this particular trip, as "very spiritual"; she "believed in demons, speaking in tongues, prophesying" (Western District, Document 473-73, p. 151). He believed that he would find in Nichols a sympathetic ear and sent her a text message explaining his predicament. He wrote (with an informality not uncommon in a text exchange): "please the moment I get back take me to your pastor in Norman ... I do have a demon", he said, "I'm beyond miserable. I've never been so close to losing my mind. ... Can your pastor help me?" Hannah responded: " ... you should talk to him about it and he'll have insight for you for sure!" When pressed as to whether Chris Bennett, the pastor at Antioch Community Church in Norman, OK, could "get rid of" the demon, Nichols responded: "idk Matt he doesn't tell us about the demons that he gets rid of every week ... but I want you to come and see anyway. Even if you just get prayer there's no harm in that" (Western District, Document 70-79, pp. 5-6). ${ }^{8}$

and virtual networks and engendering an elastic, undisciplined and pragmatic process of inspired creations, borrowings, combinations and adaptations" (R. Marshall 2016, p. 97).

8 Antioch Community Church is an independent, non-denominational evangelical church in Norman, Oklahoma. (Norman is another Oklahoma City suburb located about thirty miles south of Edmond.) Missionaries from the Antioch International Movement of Churches (AIM) and Antioch Ministries International, based in Waco, TX, planted Antioch Norman in 2009. AIM and the Antioch movement are classified as "Baptist-Charismatics". While not all southern Baptists accept the role of charismata in everyday life, there are an increasing number who do. For example, after a decade-long resistance, the Southern Baptist Convention relented, and in May 2015 they agreed to admit missionary candidates who speak in 
The urge by Durham and his Kenyan and American colleagues to turn toward spiritual warfare as a way to understand and adjudicate accusations of sexual assault is a fascinating episode in its own right. Indeed, media in Oklahoma and in Kenya, and the attorneys on the case were captivated, making much of the episode as an "illogical" sideshow, a distraction, to an otherwise serious matter. As a scholar of missionization and Africans' adoption and adaptation of Christianity in East Africa, Prichard had been working on these networks for a related scholarly project. Thus, she saw the actors' engagement with ontologies of spiritual warfare as something more than "evidence of [Durham's] irrational behavior" or as "some sort of pseudo-tribal psychological voodoo" (Doc 26, p. 5). ${ }^{9}$ Rather, Prichard noted that the discourse of spiritual warfare at play in the Durham case did not move North-South or South-North exclusively. The missionaries' understandings and invocations of spiritual warfare circulated on a complex playing field, building on and reinforcing one another as they moved along interconnected social networks. Indeed, Durham and his fellow missionaries' engagement with spiritual warfare-precisely, with a demon named "Luke" — provides clear data on the way that spiritual warfare circulates through concrete interactions within global and transnational Pentecostal/charismatic networks. Specifically, it illustrates the role that individual interactions play in shaping and reinforcing the ontologies of spiritual warfare that circulate in particular networks.

It did not take long after Menja suggested that Durham might be possessed that he fully committed to the idea of a demon controlling his actions in Kenya. ${ }^{10}$ He named his inner demon "Luke", and read Luke's control over him back onto the days and nights before the alleged assaults occurred. Durham confessed in a separate text exchange that he "cannot control himself" against Luke's wishes and that he is "powerless against his urges" (Western District, Document 15). Luke, he wrote (again with characteristic informality), "takes me at night and i am powerless over what luke wants. Yes i named him I know how crazy that is. He whispers in my ear all day and hes so hard to resist. ... Literally he takes me at night and there is nothing I can do to stop him. Im asleep, what can i do?" Durham concluded by admitting, "You honestly have no idea ... i've prayed so much, but every night luke gets what luke wants" (Western District, Document 15).

Durham's defense counsel used a series of legal filings in an attempt to explain away Luke's presence in Durham's life. In a motion to suppress essentially all verbal, written, and electronic exchanges that Durham made while in Kenya, his attorney Stephen Jones argued that "as a result of Mr. Durham's confinement, illness, and dehydration, as well as the psychological manipulation, lies by Ms. Menja, and isolation from other volunteers", Durham "became convinced" that he had a demon within him. He was "faced with a persuaded "truth" that he committed the acts as alleged", yet he argued, Durham had no recollection of committing those acts. "Taken in conjunction with his religious beliefs, relative isolation, foreign environment, and an accusatory environment ranging from aggressive to confessional in nature", Durham "internalized and accepted the explanation of his captor" (Western District, Document 63).

Durham's attorney described his client's invocation of a demon as a consequence of him being an impressionable young man coerced by a trusted elder into believing that he had a demon. His belief in Luke was, in this reading, an illogical response to stress and to Menja's power of suggestion. Indeed, Jones argued in another motion that Durham's statements were illogical and constituted "evidence of irrational behavior" (Doc 26, p. 9). Government prosecutors, for their part, argued similarly that they

tongues. This move by the Convention was part of a trend of normalizing members who embrace the "gifts" of the holy spirit. (Religion News Service)

9 In a formal statement to media, Defense counsel Stephen Jones argued that "The events that occurred in Kenya the last maybe five six days that Matt was there frankly reveal some sort of pseudo-tribal psychological voodoo practiced on him". The Oklahoman, 22 July 2014, Matt Dinger "Edmond man faces charges of sex acts with Kenyan children", accessed 3 March 2020.

10 On 13 June 2014, Eunice Menja suggested to Durham that he might have been possessed by a demon. On 15 June $2014-$ less than two full days later-Durham seems to have adopted this explanation and began to act upon it (Western District, Document 15). 
believed Durham's "sincerely believed delusions" were indicative of a mental health issue and that he was therefore incompetent to stand trial (Doc 26, p. 5).

Although Jones granted Durham's "religious beliefs" some explanatory power in the role Luke played in Durham's alleged transgressions, the unique internal logic of the international networks in which Durham and his fellow missionaries were embedded was nearly completely lost on Jones and his colleagues on the prosecution team. Indeed, there are several factors that made an attack by a non-human actor appear as a viable possibility in the minds of Durham and the rest of the Upendo contingent. The first is the relationship that Durham and his fellow American missionaries had with Eunice Menja, the founder of Upendo. Menja, a Kenyan by birth, founded Upendo in Edmond, Oklahoma, where she and her husband had been living and working for over a decade. Beloved by many, Menja loomed large in the lives and spiritual imaginations of many of Upendo's high-school aged American missionary volunteers. Durham and Menja were particularly close; she often referred to him as her son and he "trusted her to near devotion" (Western District, Document 63, p. 8). Menja has bachelor's and master's degrees in Human Development and Family Science from Oklahoma State University, and has worked as an adjunct professor of psychology at two universities in the state. Furthermore, she was a deeply religious woman; witnesses testified that Menja "openly believes in evil spirits" and that she "openly encourages certain Upendo volunteers to speak in tongues" (Western District, Document 63, p. 7). Given these credentials, her near-celebrity status in the small evangelical community of Edmond, and her close relationship with Durham, the young man had a habit of turning to her for "psychological expertise, personal confidence, and spiritual guidance" (Western District, Document 63, p. 21). It is no wonder, then, that Menja's suggestion that Durham was possessed resonated with him.

\section{Non-Denominational Networks of Possession}

There is a second, and more significant, factor that made an attack by a non-human actor (such as the demon Durham named "Luke") a viable possibility to Menja, Durham, and their American colleagues. They, as well as many Kenyan Upendo staffers, are all involved in the same reciprocal networks along which these ontologies circulate. In Juja, the Menjas and Upendo are affiliated with the Presbyterian Church of East Africa (PCEA). While one might not regularly see charismatic expressions in the United States, Presbyterians and others within mainline Protestant churches in Kenya are widely accepting of spirit Christianity. This, historians of religion in Africa make clear, is not the same sort of spirit Christianity often associated with the "traditional spirit world of Africa", but it is something new, coming in part from missionary Christianity and in part from the more recent Pentecostal/charismatic renewal of Christianity on the continent (Gifford 2009, pp. 202-3). As Paul Gifford and others argue, the idea of a spiritual cause of evil has come to characterize the PCEA as an institution: "The PCEA is currently promoting a spirit Christianity which takes it far from Presbyterianism in the West", toward "'a general Pentecostalism' that is as North American as it is African" (Gifford 2009, p. 249). Among Kenyans sympathetic to a spirit-filled Christianity, there is widespread acceptance of the link between possession by demons or other evil spirits and "antisocial activities", including homosexuality and child abuse. Moreover, as we have seen, Durham and other among Upendo's American volunteers embraced strands within contemporary Bible Belt non-denominational Christianity, that understood non-human actors to act in the realm of the real-ideas at the root of Durham's text request for an exorcism at Antioch Norman.

What is significant here is that Durham's attack by a non-human actor was not something that the Upendo staffers or American volunteers believed they could remedy within the formal networks in which they operated-either judicial or denominational. Indeed, due to the fact that Durham's alleged transgressions were considered to be the fault of a non-human actor, redress in the courts-either Kenyan or American-was not a possibility. Indeed, Upendo staffers avoided reporting the abuse to authorities in Thika for six days after the allegations were first launched. Durham might have escaped prosecution entirely if it were not for a single missionary who brought the allegations to the attention 
of the United States authorities, who eventually charged him under a 2003 federal law known as the Prosecutorial Remedies and Other Tools to end the Exploitation of Children Today (PROTECT) Act.

What is perhaps more significant than the lack of judicial remedies is that Durham, Menja, and others privy to this non-human attack against Durham at Upendo implicitly agreed that they could not tap into their extant denominational networks to find advice or a remedy for the young man's alleged abuse. Durham, for example, did not seek advice from his pastor at the non-denominational, evangelical Edmond Church of Christ. Nor, for that matter, did he willingly consult the "religious counselor" from whom his father insisted he seek therapy. ${ }^{11}$ Eunice Menja did not call on her pastors at the First Presbyterian Church in Edmond (FPCE). ${ }^{12}$ None of the actors sought counsel from pastors at the PCEA in Juja Township, working instead to hide the allegations from its membership for fear of vigilante justice or other physical retribution (Western District, Document 19, p. 33). No one sought to forge continuities with traditional healers or ancestors, either (Casanova 2001). Rather, they avoided resources with official claims to religious authority in the denominational networks in which they operated, and opted instead for an exorcism at an unaffiliated, non-denominational church in Norman, Oklahoma.

This fragmentation of the denominational networks highlights a significant common ground among people involved in a very localized experience of international missionization-that is, the resonance of spiritual warfare outside of denominationally-controlled channels. As we have seen above with historical cases on the continent, this "far-flung network of people" played a vital role in circulating the ontologies of spiritual warfare (Robbins 2004, p. 125). Indeed, in the days and weeks that followed Josephine Wambugu's first round of allegations against Matthew Durham, the rhetoric of spiritual warfare moved in ways generally overlooked in the scholarly literature. It flowed not North-South, or even South-North, but along pathways that were circular in nature and mutually reinforcing in practice. Ideas that were presented to Durham by an expatriate Kenyan, living in Oklahoma but working periodically in Kenya, were recirculated in Oklahoma when Durham called on Nichols to help him access an exorcism. They gained even more traction when deployed in the United States federal court, by attorneys who may have doubted their veracity but who counted on them to resonate with jurors hearing the case. Moreover, resonate they did: the case was eventually decided against Durham. Having been found guilty on four counts under the PROTECT Act, Matthew Durham is currently serving a forty-year sentence in the United States Penitentiary in Marion, IL. In 2020, he will be twenty-five. He will never be eligible for parole.

\section{Pastor Begay's Bolo Ties}

And one of the beaded bolo ties that I had, and I presented it to the king of the South. And ... he had a very, very good spirit too. That king. He was very gentle, very nice, very friendly. And, uh, so ... I gave him a bolo tie and he said that he would make an announcement in front of everybody that he would receive that on behalf of all the Southern kings. (Begay Journal $2 / 24 / 2008)$

11 Biblical counseling, or 'nouthetics', is a reformed/fundamentalist movement, a form of Christian therapy which rejects conventional approaches to mental health care in favor of the Bible as sufficient, superior, and more authoritative than psychological science, theory, or technique (Weaver 2011). Biblical, pastoral, Christian, and faith-based counselors seek to reclaim the role of counseling within the church itself (McMinn et al. 2010). Psychological conditions or distress is best treated, many Evangelical Christians believe, with prayer, confession, and repentance rather than the "permissive and guilt-absolving premises of psychology" (Joyce 2017). "Nouthetic" or "biblical counseling" is seen by many Neo-Evangelicals, fundamentalists, and Reformed Protestants as a preferred alternative to deliverance from sin through exorcism (Weaver 2011).

12 FPCE is not a mainline Presbyterian church, but is a partner congregation in a new Presbyterian denomination, ECO. The acronym refers to the denomination's three-fold commitment to: evangelism (make disciples of Jesus Christ); covenant (connecting leaders through accountable biblical relationships founded in God's grace); and order (a commitment to a shared way of life together) (FPCEdmond.org, 2019). Churches within the ECO denomination tend to be more conservative than other Presbyterian denominations (such as the Presbyterian Church USA), and in fact, the denomination splintered from the PC(USA) in 2012, when the PC(USA) General Assembly voted to ordain partnered LGBT clergy. 
On 23 February 2008, Pastor Wallace Begay (Navajo) found himself in the middle of a "King's Peace Meal" in the interior town of Save in Benin, West Africa. Born and raised on the rural Navajo Reservation in the Southwestern United States, prior to this trip, Begay's only experiences away from home had been revival meetings on other Native American reservations in Montana and Arizona. ${ }^{13}$ None of that had prepared him in the least for the sights, smells, and extreme disorientation he experienced in his quick one-week mission trip to West Africa. Moreover, yet, despite his major cultural disorientation, Begay's ontological compass remained steady, as his frameworks for encountering the non-human world circulated across the same networks that brought him to Africa in the first place.

Pastor Begay is the Navajo pastor of a small, independent Pentecostal church located near the reservation town of Shiprock, New Mexico. His church is part of the widespread Oodlání (believers) movement, active across the Navajo Nation, with strong connections to Pentecostal/charismatic Christianity, as practiced across Native North America and globally (Marshall 2016). Pentecostal/charismatic Christianity among Navajos has grown in appeal by empowering Navajo-led ministers like Pastor Begay, who preach, sing, and practice faith healing in the Navajo language, but without compromising the bedrock neo-Pentecostal principle of the demonic nature of Traditional Navajo religion (Marshall 2015).

Marshall became familiar with Begay during extended fieldwork for her book Upward, Not Sunwise (2016) and he became one of her main consultants for that book. While conducting fieldwork for that book, Marshall was contacted one day by Pastor Begay. He had been invited, through his networks of Native North American evangelists, to accompany a mission trip to Benin. If he could get himself to New York City, they would take him the rest of the way. Pastor Wallace put Marshall to work, researching information about Benin for him, so that he could visit family, friends, and other churches on the Navajo Nation, in order to raise funds to get to New York. Marshall also assisted Begay in getting his passport, researching the necessary travel vaccinations and where to acquire them, and booking a plane ticket to and from New York City. In exchange, Pastor Begay agreed to take a mini cassette recorder with him, in order to keep a daily journal on his activities. Marshall attached a list of questions to the recorder for Begay to consider in his journal, including practical questions like "Where did you go today? What did you do? Who did you talk to? What did you eat?" as well as more reflective questions like, "What did you think about today's events? What surprised you today? What seemed normal today?" Pastor Begay was compensated for his journaling as a research assistant and received a copy of the transcribed journal.

As a first-person depiction of a Navajo man first encountering Africa, Pastor Begay's field journal is an interesting ethnographic artifact in its own right. However, for the purposes of this paper, it provides crucial information on the praxis of spiritual warfare circulation through Pentecostal/charismatic networks. In the first place, it is hard to overstate the degree of culture shock Pastor Begay was experiencing during his short trip to Benin. Without even mentioning his first experience with jet lag or malaria medication, the journal transcript reveals just how disoriented Begay was, and how aware he was of that disorientation. In one passage, he describes a trip to the marketplace (with a guide):

Well we went to the marketplace and it reminded me of Shiprock Fair with all the people. The dust. Traffic. The trash ... but this was like ... [laughs] a hundred times worse. And the smell and the dust. ... it was terrible. Really. There was just heaps and heaps of trash. It was like people trying to sell this and that. Anything, I guess, to make some money ... it was quite a shock. (Begay Journal 2/20/2008)

Begay was also horrified by the poverty he observed, saying, "The livin' conditions here and it seems like throughout the whole of Africa it's just very poor. Moreover, people are very, very poor". Cultural differences also upset him. He was disturbed by street food, commenting, "They were selling

13 He had also once traveled to a Bible conference in Missouri. 
some kind of ... I don't know if it's a rat, whatever, on a stick ... they fan it out- arms and legs stretched out and hanging on a long pole an then they wave it alongside the road for people to buy ... roasted boa constrictor [makes grossed out noise]" (Begay Journal 2/24/2008). He was also unsettled by other aspects of everyday life in Benin, including the driving etiquette and by the generators constantly flickering the electricity. He was particularly disturbed by the smells he encountered. He says:

Oh my God. The smell is just horrific. I mean, you would not believe the smell. You know, I mean it's just ... whew! And people don't ... you know, have a public bathroom or a public restroom. It's like they just pee wherever .... And it's not against the law or anything. It's just, you know, you gotta go, you just stand there and just ... let it go! [laughs]. (Begay Journal 2/24/2008)

Moreover, in his record of what he was eating, he seems to have survived on French fries for the entire week of his visit (despite his repeated declarations that he was willing to try frog legs). "It's just", he says, "I didn't trust their chicken" (Begay Journal 2/24/2008).

The journals also reflect Begay's own awareness of his disorientation. On the first full day in Ouidah (a coastal town in Benin), Begay accompanied the mission team on a visit to a local "King". His reflection on his own culture shock is astute, even naming it as such. He said:

Well ... today we went over to one of the King's ... uh, palace. And we were greeted. Um, we were welcomed to the palace. We were greeted by drums and singing ... beautiful voices. We went inside ... it was scary at first. I was knock[ing] ... my knees were knocking. [Laughs]. I was scared, like. I didn't know what to expect. Like, you know, they didn't tell me what to expect, or not to be afraid, whatever. But ... to me it was sort of scary. Culture shock, is what it is, I guess. (Begay Journal 2/22/2008)

Without a doubt, Pastor Wallace Begay encountered Benin through a lens of shock.

Yet, in spite of his admitted culture shock, Begay easily assimilated ontological threats into a familiar worldview and dealt with them in recognizably Pentecostal/charismatic ways. The second "king" they visited in Ouidah was more "traditional". While Begay had been able to get over the shock of the African drumming that greeted them at the first king's palace (even eventually joining in the dancing), he interpreted the drumming at the palace of the second king as significantly more threatening. Begay notes that this king was holding "voodoo fetishes" and was accompanied by "voodoo priests". As they entered, they "went in with a lot of drumming, lot of singing, the same way. But the atmosphere in that place was different. Uh, [it] had a different atmosphere. Had a lot of spiritual warfare on our part, uh when we went into that place, in his palace" (Begay Journal 2/24/2008). In this passage, Begay is recognizing traditional symbols of spiritual power, transliterating them as demonic, and describing concrete actions he took in order to protect himself from ontological threat. These are the same concrete actions he had used in the past to protect himself and his mother from the supernatural attacks of Navajo skinwalkers (Marshall 2016).

In another part of the journal, he describes coming under supernatural attack early in the morning of 23 February. That day, the party had traveled from the coastal town of Ouidah to the interior town of Save. The motel in which they lodged that night was significantly sparser than their lodgings in Ouidah, so it is entirely likely that Begay (still only in his third day in the country) was feeling unsettled to begin with. In any case, in the journal, Begay reports that he woke up around midnight. He heard what sounded like pebbles being thrown at his door. He interpreted this sound as an agentive action-as either a human or non-human actor deliberately attacking the party. "Someone was throwing pebbles at our door", he says. His response is to engage in the attack, supernaturally. He says:

And so, I went and I got my prayer shawl out, and I just wrapped it around myself. I just got up and ... got up and started to pray. The power of prayer ... I tell you ... you know. 
It shields you. I just prayed the blood [of Jesus] ${ }^{14} \ldots$ I prayed for like three hours. And uh, didn't go to sleep until about 3 o'clock. (Begay Journal 2/24/2008)

Because of this active shielding through prayer, he reports that, unlike the rest of the party, he did not have any nightmares or stomach problems. In the journal, he directly attributes this outcome to his three hours of shielding prayer. Interestingly, however, even though prayer was shielding him, his watch stopped. Begay commented, "But they said that that's what happens when they get into voodoo ... witchcraft places, you know. That watches will stop working and all this crazy phenomenon will start happening" (Begay Journal 2/24/2008). So, even though Begay dismissed this inconvenience as a trivial matter, he still understood it to be supernaturally predicated.

There is nothing distinctively African or Navajo about the kind of spiritual warfare being waged here against the stopping of watches. Begay is clearly deploying spiritual warfare techniques (intensive long-duration prayer, using the "blood of Jesus" as a spiritually protective shield) that are widely disseminated across global Pentecostal/charismatic networks. There is nothing really that moves beyond even stereotypes of Africa in his description of the "voodoo priests" or witchcraft, since his interactions with actual Africans remained fairly superficial. While the guide offered to take them to "services" that were happening "all the way up and down the road" between Ouidah and Save, the exhausted party declined, missing the opportunity to learn about Benin Pentecostal/charismatic Christianity localization. However, what the Pastor Begay journal does contribute to our understanding of the actualization of spiritual warfare ontologies in circulation is the ontological value of those very circulations themselves. In encountering ontological threats in Africa, Pastor Begay not only engaged globalized rituals of spiritual warfare, he also attempted to neutralize ontological threats in a distinctively Navajo way: by building reciprocal relationships with powerful actors. He did this through bolo ties.

\section{Networks of Reciprocity}

One of the notable features of Pastor Begay's journals is the careful inventories he kept of what gifts he distributed, and to whom. For instance, in the visit to the "first king" in Ouidah, Pastor Begay recounts:

... When we were leaving, after I danced, gave his pastor a beautiful necklace, my turquoise choker. I wrapped it around her neck, and she also sang another song ... . It was a really good spirit that was there. And I know that the Lord's gonna bless the first king, Amen. And $u h . .$. we left there, and he wants to come to America. He wants to come to one of our revivals. (Begay Journal 2/24/2008)

In this passage, the giving of gifts is directly linked in Pastor Begay's stream of consciousness audio journaling, with reciprocal visiting. As discussed below, for him, the giving of gifts actualizes the building of relationships.

A few days later, the mission party was in the interior town of Save, attending a "King's Peace Meal" for local dignitaries. Begay's journal recounts in detail what was given and to whom, as in this passage: "I also gave two necklaces, a choker necklace to the king and I also gave a necklace to his wife" (Begay Journal 2/24/2008). Furthermore, included is his record of the gifts he received in exchange. "In return he gave us like strips of green and red ... um ... cloths. I guess you would call it. He gave those to us" (Begay Journal 2/24/2008). The most interesting gifting passage is the narrative of one bolo tie. During the ceremony, Pastor Begay reads a "good spirit" on one of the visiting kings in attendance.

14 This phrase, "Pray the Blood of Jesus", is a partial reference to a larger theological ideology in Pentecostal/charismatic circles that one can pray (or "plead") the blood of Jesus for protection. In this ideology, the "blood" is conceptualized as an invisible barrier that (because it is ontologically powered by the sacrifice of Jesus on the cross) is a strong shield against attack by demonic forces. In this transcript, note that Pastor Begay does not even finish the phrase. Within his circles, the same concept is signaled by the phrase "prayed the blood". 
Aware that gifting out of turn may cause jealousy and disruption, Begay asks the guide (Henry) if it would be permissible to give that king a bolo tie. After a bit of hesitation, Begay "got permission" to do so. He recounts that this king (whom he calls "the king of the South") has a large kingdom in the south and was so pleased with the gift of the bolo tie that others on the mission team noticed that he continued to wear it the next morning, even after he had removed all his other necklaces. As with before, the giving of this gift (recounted in detail in the journal) is paired with an invitation for further reciprocal relationships with the Southern King. "We talked with him and he gave us his cards. And he wants to invite us to come to his kingdom. Sometime ... But he wants to gather at least 25,000 people and he wants us to come and bring the peace meal to his kingdom also" (Begay Journal 2/24/2008).

Begay's gifting fits long-established techniques of fostering reciprocal relationships through the exchange of material goods, within both Native American and African communities. This reliance on fostering networked ties fits well within the decentralized structure of Pentecostal/charismatic Christianity. Moreover, as the literature above suggests, the network structure is very much part of how this movement has spread across the globe so quickly. However, from a Navajo perspective, facilitating reciprocal relationships through material goods is about more than fostering positive human relationships; it also has prophylactic ontological power. Networked social relations offer protection based on three axioms. First, from a traditional Navajo perspective, reciprocal relationships can be made with any actor, whether human or non-human. As Charlotte Frisbie explains, "The Navajo ceremonial system ... [is] based on a chain of reciprocity which stretches between the sacred and profane worlds and that includes everyone, from the Holy People and singers to the one-sung-over and students", Frisbie (1987, p. 89). ${ }^{15}$ Moreover, while recent Navajo (Diné) Studies scholars have emphasized the centrality of kinship ties $\left(k^{\prime} e^{\prime}\right)$ as the fundamental building block of Navajo social life, ${ }^{16}$ these ties extend into the non-human world as well. For instance, a traditional Navajo prayer may address the Holy People using the terminology for grandparent, placing the supplicant in the position of the grandchild. Because of the strong ethical obligation to care for weaker relatives, this phrasing of prayers is a way of influencing the actions of powerful non-human actors by invoking reciprocal kin obligations (Gill 1987, p. 118). So, reciprocal kinship ( $\left.k^{\prime} e ́\right)$ ties can link both human and non-human actors, and Pastor Begay was operating in a perfectly consistent manner with his Navajo upbringing in trying to build reciprocal ties with actors in Benin.

The second axiom that explains the protecting character of reciprocal networks is that material goods can cement and influence these reciprocal social ties. Again, according to Frisbie, in the Navajo ceremonial system, "one is required to make gifts or 'offerings' (yeel) to those whose services and assistance are desired. Once such gifts are accepted, the receiver is compelled to respond; the gifts simultaneously compel and insure the efficacy of the performance" Frisbie (1987, p. 89). Scholars have long noted that this use of material goods exchange to cement reciprocal ties between human actors is the same principle used to cement reciprocal ties across the human/non-human divide. As Reichard noted in 1949, offerings are made "in the spirit of barter", in order to establish reciprocal relations with deities and achieve a desired end (Reichard 1949, p. 68). As an example of this bartering attitude, Reichard provides a line from a traditional Navajo prayer: "I have made your offering to you/My mind restore for me" (Reichard 1949, p. 68). So, in carefully cataloguing his exchange with various actors in Benin, Pastor Begay wasn't just expressing his desire to make friends, he was also ontologically activating an alignment with what he likely saw as a cascading network of his interlocutor's social networks, both human and non-human. ${ }^{17}$

15 In Navajo Ceremonials, the "singer" is the healer (sometimes called the "medicine man"), and the "one-sung-over" is the patient. This is a direct translation of the Navajo word.

16 See, for instance, Lee (2014).

17 Begay's African interlocutors might also have been thinking about these as reciprocal exchanges capable of cementing and influencing social ties within the human, and across the human/non-human divide. Indeed, Africans across the continent have long imbued gifting and exchange with power beyond the economic, granting it moral, aesthetic, political, and symbolic power as well (Shipton 2007). Because of the value that unique individuals held in societies throughout precolonial Africa 
The importance of these materially activated social networks for our conversation about spiritual warfare is in the third axiom: that these networks can be ontologically shielding. In presenting the "King of the South" with a bolo tie, Pastor Wallace was both aligning himself with the spiritual family of the Southern King, and fundamentally obligating (though material exchange) their protection against "bad spirits" as well. In this way, he was using long-held Navajo techniques for controlling powerful (and therefore potentially dangerous) non-human interlocutors (Garrity 2000, p. 534).

In traditional Navajo ontological frameworks, the exchange of goods has the potential to bridge the human/non-human divide, and it is therefore one of the primary ways in which traditional Navajo ceremonialism aims to provide protection against ontological threats. More broadly, the entire traditional Navajo cosmological framework is about perpetuating harmonious relationships with kin $\left(k^{\prime} e\right)$, both human and non-human, as a way of protecting an individual against ontological threats (like witches and skinwalkers). So, in building positive human relationships with those "kings" in Benin whom he felt had "a good spirit", Pastor Begay was actively neutralizing ontological threats through the time-worn Navajo technique of making kin. In this way, ontological threats he felt while in Benin filtered through interactions that were informed by his Navajo perspective, but mixed with and refracted through specific interactions with West Africans.

\section{Conclusions}

This paper has explored two concrete instances of spiritual warfare in contact, illustrating, in detail, how missionaries negotiate conversations between localities. Actors from Juja, Edmond, Save, and Shiprock made legible various ontologies of spiritual warfare that they brought with them and that they encountered, reframing them in the Pentecostal/charismatic missionary networks in which they were embedded and redeploying them to protect themselves and their loved ones. Begay's focus on reciprocal networks among missionaries promoted the continuous circulation and adaptation of ontologies about spiritual warfare and the shape it takes in particular locales. The fragmentation of the denominational networks in Durham's case illustrates that spiritual warfare resonates outside of denominationally controlled channels in similar ways for international missionaries. What becomes clear in all of this is the power of interconnected networks as a motivating factor in Pentecostal/charismatic engagement with spiritual warfare.

The way in which Begay and Durham engaged with ontologies of spiritual warfare through these networks also offers a path out of the debate between continuity and rupture. Here, we see clearly that individuals (and their communities) are not just waging spiritual warfare against Christian demons, or assigning unseen forces to the "traditional" realm, but they are reframing the unseen universe into blanket ontologies of good and evil. Matthew Durham and Eunice Menja did this when they invoked possession as a way to absolve Durham from the agency and guilt associated with alleged child molestation, reframing Durham and his embodied innocence as good, and "Luke" and his actions as evil. What resulted was an enlivened universe not strictly Kenyan or Oklahoman, yet also not exactly the product of either Bible-Belt non-denominational Christianity or PCEA theological mission.

Begay also read past local (and localized) nuances of threat and protection, assuming a universal demonic power associated with his overall unease, as well as a universal technique of recruiting good allies when waging spiritual war. His careful attention to cementing these alliances through material

(but perhaps particularly in Equatorial societies), the payment of bridewealth, for example, was a vital tool in composing and cementing social networks (Guyer and Belinga 1995). Relatedly, long-standing cultural practices throughout the continent treat exchange and affect as mutually constitutive. In some cases, gifting and reciprocal exchange can be understood not only to solidify, but to create, relationships de novo. In Madagascar, for example, young women claimed that "there was no such thing as fitiavina [love] without money", suggesting money was a central driver in relationships of emotional attachment and physical desire (Cole in Thomas and Cole 2009; see also Hunter 2010). The same can be seen in relations among the living and their ancestors; reciprocity is often a central tenet underpinning the relationship between ancestors and descendants. Among the Luo in Kenya, for example, the virtue of "entrustment" guides how they conceive of relations between the living and their spirits and divinity (Shipton 2007). 
goods calls our attention to their importance, as well as the way in which our attention to "ontologies" (in debates about continuity versus rupture) may not be as important as attention to "strategies". Crucially, both of these case studies emphasize how fluid and malleable ideas about good and evil become as they circulate through known networks.

Finally, it becomes clear through these case studies that focusing on localized instances of contact can completely upend our assumptions about the flows of Christian missionary ideas and ontologies from North to South or core to periphery. As studies cited above have shown for earlier historical periods, there is no standard path of movement in these two cases, no set directionality of intellectual flow. Rather, there is a circulation and a mutual reinforcement of ideas as they move around the globe through networks of people. These on-going conversations between localities, permissible because of technology, constant travel, affective ties, and intellectual engagement, reframe our understanding of conversion and of the power (and future) of missionization.

Author Contributions: Conceptualization, A.P. and K.M.; Formal analysis, A.P. and K.M.; Investigation, A.P. and K.M.; Writing - original draft, A.P. and K.M.; Writing-review \& editing, A.P. and K.M. All authors have read and agreed to the published version of the manuscript.

Funding: Prichard's research was funded by the University of Oklahoma Foundation and an Arts and Humanities Faculty Fellowship from the Research Council at the University of Oklahoma. Marshall's research was funded by the Dolores Zohrab Liebmann Fund and a University of Oklahoma Junior Faculty Fellowship.

Acknowledgments: Andreana Prichard would like to acknowledge the numerous anonymous members of the evangelical community based in Oklahoma City and Edmond, Oklahoma, conversations with whom contributed to her understanding of the networks in which Durham, Menja, and their co-missionaries traveled. Conversations with several students and missionaries also contributed to this understanding. Theo Schlecht's impending arrival and early weeks of life spurred the completion of this article. Kim Marshall would like to acknowledge the support of Pastor Wallace Begay, his family, and his church community in facilitating this research. Marshall research was carried out under Navajo Nation Office of Historic Preservation permit \#C0614-E, Indiana University Human Subjects Research Review Board protocols \#06-11039 and \#07-12188, and the University of Oklahoma Institutional Review Board protocol \#0560.

Conflicts of Interest: The authors declare no conflict of interest.

\section{References}

Amster, Matthew H. 2009. Portable Potency: Christianity, Mobility and Spiritual Landscapes among the Kelabit. Anthropological Forum 19: 307-22. [CrossRef]

Annis, Sheldon. 1987. God and Production in a Guatemalan Town. Austin: University of Texas Press.

Bastian, Jean Pierre. 1993. The Metamorphosis of Latin American Protestant Groups: A Sociohistorical Perspective. Latin American Research Review 28: 33-61.

Blumhofer, Edith. 1993. Aimee Semple McPherson: Everybody's Sister. Grand Rapids: Eardmans.

Bowen, Kurt Derek. 1996. Evangelism and Apostasy: The Evolution and Impact of Evangelicals in Modern Mexico. In McGill-Queen's Studies in the History of Religion, 23. Montréal and Buffalo: McGill-Queen's University Press.

Butler, Melvin. 2019. Island Gospel: Pentecostal Music and Identity in Jamaica and the United States. Champaign: University of Illinois Press.

Casanova, José. 2001. Religion, The New Millennium, and Globalization. Sociology of Religion 62: 415-41. [CrossRef]

Chesnut, R. Andrew. 1997. Born Again in Brazil: The Pentecostal Boom and the Pathogens of Poverty. New Brunswick: Rutgers University Press.

Chua, Liana. 2012. Conversion, Continuity, and Moral Dilemmas among Christian Bidayuhs in Malaysian Borneo. American Ethnologist 39: 511-26. [CrossRef]

Cole, Jennifer. 2009. Love, Money, and Economies of Intimacy in Tamatave, Madagascar. In Love in Africa. Edited by Jennifer Cole and Lynn M. Thomas. Chicago: University of Chicago Press, pp. 109-34.

Coleman, Simon. 2000. The Globalisation of Charismatic Christianity: Spreading the Gospel of Prosperity. Cambridge: Cambridge University Press.

Coleman, Simon, and Rosalind I. J. Hackett. 2015. Introduction: A New Field? In The Anthropology of Global Pentecostalism and Evangelicalism. Edited by Simon Coleman and Rosalind I. J. Hackett. New York: New York University Press, pp. 1-40. 
Comaroff, Jean, and John Comaroff. 1991. Of Revelation and Revolution, Volume 1: Christianity, Colonialism, and Consciousness in South Africa. Chicago: University of Chicago Press.

Comaroff, Jean, and John Comaroff. 1997. Of Revelation and Revolution, Volume 2: The Dialectics of Modernity on a South African Frontier. Chicago: University of Chicago Press.

Cox, Harvey. 1995. Fire from Heaven: The Rise of Pentecostal Spirituality and the Reshaping of Religion in the Twenty-First Century. Reading: Addison-Wesley.

Daswani, Girish. 2013. On Christianity and Ethics: Rupture as Ethical Practice in Ghanaian Pentecostalism. American Ethnologist 40: 467-79. [CrossRef]

Elisha, Omri. 2015. Personhood: Sin, Sociality, and the Unbuffered Self in US Evangelicalism. In The Anthropology of Global Pentecostalism and Evangelicalism. Edited by Simon Coleman and Rosalind I. J. Hackett. New York: New York University Press, pp. 41-56.

Engelke, Matthew. 2010. Past Pentecostalism: Notes on Rupture, Realignment, and Everyday Life in Pentecostal and African Independent Churches. Africa 80: 177-99. [CrossRef]

Frisbie, Charlotte J. 1987. Introduction: A Special Symposium Issue on Navajo Mortuary Practices and Beliefs. American Indian Quarterly 4: 303-8.

Garrard-Burnett, Virginia. 1998. Protestantism in Guatemala: Living in the New Jerusalem. Austin: University of Texas Press.

Garrity, John F. 2000. Jesus, Peyote, and the Holy People: Alcohol Abuse and the Ethos of Power in Navajo Healing. Medical Anthropology Quarterly 14: 521-42. [CrossRef]

Geschiere, Peter. 2017. Afterword: Academics, Pentecostals, and Witches: The Struggle for Clarity and the Power of the Murky. In Pentecostalism and Witchcraft: Spiritual Warfare in Africa and Melanesia. Edited by Knut Rio, Michelle MacCarthy and Ruy Blanes. London: Palgrave Macmillan, pp. 281-90.

Gifford, Paul. 2009. Christianity, Politics, and Public Life in Kenya. Oxford: Oxford University Press.

Gill, Sam D. 1987. Native American Religious Action: A Performance Approach to Religion. Columbia: University of South Carolina Press.

Guyer, Jane, and Samuel Belinga. 1995. Wealth in People as Wealth in Knowledge: Accumulation and Composition in Equatorial Africa. Journal of African History 36: 91-120. [CrossRef]

Hackett, Rosalind I. J. 1998. Charismatic/Pentecostal Appropriation of Media Technologies in Nigeria and Ghana. Journal of Religion in Africa 28: 258-77. [CrossRef]

Harris, Olivia. 2006. The Eternal Return of Conversion: Christianity as Contested Domain in Highland Bolivia. In The Anthropology of Christianity. Edited by Fenella Cannell. Durham: Duke University Press, pp. 51-76.

Helgen, Erika. 2020. Religious Conflict in Brazil: Protestants, Catholics, and the Rise of Religious Pluralism in the Early Twentieth Century. New Haven: Yale University Press.

Hollenweger, Walter J. 1997. Pentecostalism: Origins and Development Worldwide. Peabody: Hendrickson.

Hunter, Mark. 2010. Love in the Time of AIDS: Inequality, Gender, and Rights in South Africa. Bloomington: Indiana University Press.

Ingalls, Monique, and Amos Yong, eds. 2015. The Spirit of Praise: Music and Worship in Global Pentecostal-Charismatic Christianity. University Park: Penn State University Press.

Jorgensen, Dan. 2014. Mining Narratives and Multiple Geographies in Papua New Guinea: OK Tedi, the Emerald Cave, and Lost Tribes. Journal de la Société des Océanistes 138: 23-36. [CrossRef]

Joyce, Kathryn. 2017. The Rise of Biblical Counseling. Pacific Standard, June 14.

Kamsteeg, Frans. 1998. Prophetic Pentecostalism in Chile: A Case Study on Religion and Development Policy. Lanham: Scarecrow.

Kiernan, Jim. 1992. The Herder and the Rustler: Deciphering the Affinity between Zulu Diviner and Zionist Prophet. African Studies 51: 231-42. [CrossRef]

Kodesh, Neil. 2008. Networks of Knowledge: Clanship and Collective Well-Being in Buganda. Journal of African History 49: 197-216. [CrossRef]

Krause, Kristine. 2015. Orientations: Moral Geographies in Transnational Ghanaian Pentecostal Networks. In The Anthropology of Global Pentecostalism and Evangelicalism. Edited by Simon Coleman and Rosalind I. J. Hackett. New York: New York University Press, pp. 75-94.

Lampe, Frederick P. 2010. The Anthropology of Christianity: Context, Contestation, Rupture, and Continuity. Reviews in Anthropology 39: 66-88. [CrossRef] 
Landau, Paul. 1999. 'Religion' and Christian Conversion in African History: A New Model. Journal of Religious History 23: 8-30. [CrossRef]

Landau, Paul. 2000. Hegemony and History in Jean and John L. Comaroff's 'Of Revelation and Revolution.' Africa 70: 501-19.

Larson, Pier M. 1997. 'Capacities and Modes of Thinking': Intellectual Engagements and Subaltern Hegemony in the Early History of Malagasy Christianity. American Historical Review 102: 136-38. [CrossRef]

Laugrand, Frédéric B., and Jarich G. Oosten. 2010. Inuit Shamanism and Christianity: Transitions and Transformations in the Twentieth Century. Montreal: McGill-Queen's University Press.

Lee, Lloyd. 2014. Introduction. In Diné Perspectives: Revitalizing and Reclaiming Navajo Thought. Edited by Lloyd L. Lee. Tucson: University of Arizona Press, pp. 3-13.

Lehmann, David. 2001. Charisma and Possession in Africa and Brazil. Theory, Culture E Society 18: 45-74.

Lindhardt, Martin. 2015. Mediating Money: Materiality and Spiritual Warfare in Tanzanian Charismatic Christianity. In The Anthropology of Global Pentecostalism and Evangelicalism. Edited by Simon Coleman and Rosalind I. J. Hackett. New York: New York University Press, pp. 147-60.

Macdonald, Fraser. 2015. Lucifer is Behind Me: The Diabolisation of Oksapmin Witchcraft as Negative Cosmological Integration. Asia Pacific Journal of Anthropology 16: 464-80. [CrossRef]

Manning, Frank E. 1980. Pentecostalism: Christianity and Reputation. In Perspectives on Pentecostalism: Case Studies from the Caribbean and Latin America. Edited by Stephen D. Glazier. Lanham: University Press of America, pp. 177-87.

Marshall, Kimberly Jenkins. 2015. Non-Human Agency and Experiential Faith among Diné Oodlání, "Navajo Believers". Anthropologica 57: 397-409.

Marshall, Kimberly Jenkins. 2016. Upward, Not Sunwise: Resonant Rupture in Navajo Neo-Pentecostalism. Lincoln: University of Nebraska Press.

Marshall, Ruth. 2009. Political Spiritualities: The Pentecostal Revolution in Nigeria. Chicago: University of Chicago Press.

Marshall, Ruth. 2016. Destroying Arguments and Captivating Thoughts: Spiritual Warfare Prayer as Global Praxis. Journal of Religious and Political Practice 2: 92-113. [CrossRef]

Martin, David. 1990. Tongues of Fire: The Explosion of Protestantism in Latin America. Cambridge: Blackwell Press.

Matory, J. Lorand. 2005. Black Atlantic Religion. Princeton: Princeton University Press.

McMinn, Mark R., Ryan C. Staley, Kurt C. Webb, and Winston Seegobin. 2010. Just What is Christian Counseling Anyway? Professional Psychology: Research and Practice 41: 391-97. [CrossRef]

Meyer, Birgit. 1999. Translating the Devil: Religion and Modernity Among the Ewe in Ghana. Edinburgh: Edinburgh University Press for the International African Institute.

Meyer, Birgit. 2004. 'Praise the Lord': Popular Cinema and Pentecostalite Style in Ghana's New Public Sphere. American Ethnologist 31: 92-110. [CrossRef]

Miller, Ivor. 2012. Voice of the Leopard: African Secret Societies and Cuba. Oxford: University of Mississippi Press.

O'Neill, Kevin. 2015. Politics of Prayer: Christianity and the Decriminalization of Cocaine in Guatemala. In The Anthropology of Global Pentecostalism and Evangelicalism. Edited by Simon Coleman and Rosalind I. J. Hackett. New York: New York University Press, pp. 214-27.

Obadare, Ebenezer. 2018. Pentecostal Republic: Religion and the Struggle for State Power in Nigeria. Chicago: University of Chicago Press.

Ono, Akiko. 2012. You Gotta Throw Away Culture Once You Become Christian: How 'Culture' is Redefined among Aboriginal Pentecostal Christians in Rural New South Wales. Oceania 82: 74-85. [CrossRef]

Prichard, Andreana. 2017. Sisters in Spirit: Christianity, Affect, and Community Building in East Africa, 1860-1970. East Lansing: Michigan State University Press.

Pype, Katrien. 2017. Branhamist Kindoki: Ethnographic Notes on Connectivity, Technology, and Urban Witchcraft in Contemporary Kinshasa. In Pentecostalism and Witchcraft: Spiritual Warfare in Africa and Melanesia. Edited by Kunt Rio, Michaelle MacCarthy and Ruy Blanes. London: Palgrave MacMillan, pp. 115-44.

Reichard, Gladys. 1949. The Navaho and Christianity. American Anthropologist 51: 66-71. [CrossRef]

Rio, Knut, Michelle MacCarthy, and Ruy Blanes. 2017. Introduction to Pentecostal Witchcraft and Spiritual Politics in Africa and Melanesia. In Pentecostalism and Witchcraft: Spiritual Warfare in Africa and Melanesia. Edited by Knut Rio, Michelle MacCarthy and Ruy Blanes. London: Palgrave Macmillan, pp. 1-36. 
Robbins, Joel. 2003. On the Paradoxes of Global Pentecostalism and the Perils of Continuity Thinking. Religion 33: 221-31. [CrossRef]

Robbins, Joel. 2004. The Globalization of Pentecostal and Charismatic Christianity. Annual Review of Anthropology 33: 117-43. [CrossRef]

Shipton, Parker. 2007. The Nature of Entrustment: Intimacy, Exchange, and the Sacred in Africa. New Haven: Yale University Press.

Stoll, David. 1990. Is Latin America Turning Protestant?: The Politics of Evangelical Growth. Berkeley: University of California Press.

Stritecky, Jolene M. 2001. Israel, America, and the Ancestors: Narratives of Spiritual Warfare in a Pentecostal Denomination in Soloman Islands. Journal of Ritual Studies 15: 62-78.

Sweet, James. 2011. Domingos Alvares, African Healing, and the Intellectual History of the Atlantic World. Chapel Hill: University of North Carolina Press.

Synan, Vinson. 1997. The Holiness-Pentecostal Tradition: Charismatic Movements in the Twentieth Century. Grand Rapids: Eardmans.

Thornton, John K. 1998. The Kongolese Saint Anthony Dona Beatriz Kimpa Vita and the Antonian Movement, 1684-1706. Cambridge: Cambridge University Press.

Weaver, John. 2011. Unpardonable Sins: The Mentally Ill and Evangelicalism in America. The Journal of Religion and Popular Culture 23: 65-81. [CrossRef]

(C) 2020 by the authors. Licensee MDPI, Basel, Switzerland. This article is an open access article distributed under the terms and conditions of the Creative Commons Attribution (CC BY) license (http://creativecommons.org/licenses/by/4.0/). 
Article

\title{
Reconversion and Retrieval: Nonlinear Change in African Catholic Practice
}

\author{
Devaka Premawardhana \\ Department of Religion, Emory University, 201 Dowman Drive, 30322 Atlanta, GA, USA; dpremaw@emory.edu
}

Received: 2 June 2020; Accepted: 10 July 2020; Published: 13 July 2020

\begin{abstract}
Against models of conversion that presume a trajectory or a progression from one religion to another, this article proposes a less linear, more complex, and ultimately more empirical understanding of religious change in Africa. It does so by foregrounding the particularities of Roman Catholicism-its privileging of materiality and practice, and of community and tradition. In the course of so doing, this article explores the overlaps between modernist thinking, Protestant ideals, and teleological trajectories; the factors behind reconversion and religious oscillation in sub-Saharan African contexts; inculturation and other continuity paradigms in Catholicism; the significance of the Renaissance for early modern Catholic missions; and the ministry of a contemporary Italian Catholic missionary serving in northern Mozambique. This article proposes that Catholic history and Catholic assumptions offer valuable resources for thinking beyond and thinking against linear models of religious conversion.
\end{abstract}

Keywords: Roman Catholicism; conversion; reconversion; modernity; linearity; missionaries; Mozambique

\section{Introduction}

This is a story of crucifixes and converts, of the transmission and reception of religious images, ideas, and institutions in an African missionary encounter that transformed everything and everyone involved. When Italian-born Roman Catholic missionaries arrived among the Makhuwa of northern Mozambique in the early twentieth century, they came bearing the standard European crucifix. The image of the crucified Christ was the familiar one in Catholic iconography-the savior laid bare on a cross, nailed to two straight bars meeting at a perfect right angle. Before long, though, things took new shape-sometimes the body of Christ (made to display a subtly more feminine shape), but mostly the cross on which he lay. Its right angle was softened and its rectilinear bars curved, allowed to undulate and twist as wood in the natural world often does. When Catholic missionaries initially arrived among the Makhuwa, they came insisting that converts leave much behind: their past, their traditions, their ancestors. But later leaders came to soften their rigidity, and with it their most sacred symbol.

My first book on Makhuwa religion chronicled the ambivalence with which another form of Christianity—Pentecostalism—has been received in northern Mozambique (Premawardhana 2018). Unlike everywhere else in sub-Saharan Africa (or so it seems), here Pentecostal churches have failed to flourish. I argued that this owes largely to the reluctance of the Makhuwa, until recently a semi-nomadic hunting people, to affix to one place or one institution. While I emphasized the Makhuwa disposition toward mobility and malleability, Pentecostal pastors themselves pin blame on the local Catholic priests and catechists, on the manner in which they permit people to be Christian while still propitiating their ancestors and performing traditional ceremonies. Catholicism in this way has come to resonate, in a way Pentecostalism does not, with the Makhuwa predilection for mobility and plurality, for flexibility and accommodation. This goes far toward explaining Catholicism's successful spread in the region-claiming approximately $50 \%$ of the district population after a century 
of presence-and, for the same reason, Pentecostalism's failure. Basing this article partially on my Mozambican fieldwork and partially on existing scholarship that I review and synthesize, I elaborate here (more than I could in my first book) on the Catholic dimension of the story. I explore aspects of the Catholic tradition (in this article, I mean by this specifically the Roman Catholic tradition) that have lent it a capacity to embrace the "old" even while introducing the "new", to bend without breaking-not unlike the Makhuwa people, not unlike the Makhuwa crucifix.

The subject of this article is religious conversion in Roman Catholic perspective and in the context of sub-Saharan Africa, particularly as the topic has been addressed in anthropological literature. The classic statement on religious conversion in sub-Saharan Africa belongs to Robin Horton. In a series of articles in the 1970s, Horton argued that conversion to Islam and Christianity corresponds with larger political and economic shifts Africans underwent during the colonial period: from relatively bounded microcosms (e.g., the stereotypical African village) to relatively open macrocosms (e.g., the globalized nation-state). Noteworthy in Horton's model is his recognition of the capacity of traditional religions to manage this change, insofar as African cosmologies also (typically) have a Supreme Being that governs at a universal scale well beyond that of the lower or lesser spirits. In the sociological shift from the micro scale to the macro scale, that Supreme Being is activated, but so too is the appeal of the monotheistic God of Islam and Christianity. Thus, the "world religions" really only catalyze or stimulate cosmological changes already transpiring from the bottom-up, changes "that were 'in the air' anyway" (Horton 1971, p. 104). While commendable for privileging African agency in the conversion process, more problematically Horton operates with what is, in Western thought, a mostly taken-for-granted teleology - wherein progress, evolution, and change in general are assumed to be unidirectional and irreversible. This is the operative trajectory in most accounts (not just Horton's) of religious conversion-from one religion to another religion.

This has not gone uncontested, though, even within the social sciences. Take, for example, an article by Mario Aguilar, the title of which-"African Conversion from a World Religion"—-reveals an alternative, one involving fluidity and "reconversion" insofar as the Waso Boorana of East Africa stress traditional practices even while keeping Muslim public rituals (Aguilar 1995). Consider too an article by Robert Baum, who also describes as "reconversion" the manner in which the Diola of West Africa reject, in this case, Christianity after first embracing it (Baum 1990). Both scholars follow Horton in emphasizing local African dynamics-herd diversification strategies in the case of Aguilar, indigenous spiritual needs in the case of Baum. But both authors deploy these local dynamics against the other element of Horton's theory of conversion: its assumption of linearity. This article echoes Aguilar's and Baum's earlier challenges to Horton's teleology by highlighting the phenomenon of "reconversion"- by which I mean nonlinear religious change often entailing a return to that from which one earlier moved away-in cases, such as those of the Makhuwa, where becoming Catholic has not meant renouncing indigenous cultural or religious traditions. This article differs from those mentioned, however, by shifting registers from the local to the translocal, indeed to arguably the most global of all institutions. It highlights the capacity of one macrocosmic factor to help condition the possibility of bi-directionality in Catholic conversion: the factor of Catholicism itself. I argue that the particularities of Roman Catholicism-its privileging of materiality and practice, of community and tradition, and of continuities across epochs and cultures-open analytic space for a less linear, more complex, and ultimately more empirical understanding of religious conversion in sub-Saharan Africa.

\section{Teleology of Modernity}

There is a connection-an analogy at least-between linear models of religious change and what James Ferguson calls the "teleological evolutionary narratives" operative in the natural sciences and social sciences alike, narratives assuming linear movement from one discrete stage to another (Ferguson 1999, pp. 42-43). Anthropologists of religious change have not easily escaped the pull of modernist thinking (Gooren 2014, pp. 103-4), though scholars have noted the affinity. Birgit Meyer, for example, has commented on the consonance between conversion, conceptualized as rupture 
with the past, and "modernity's self-definition in terms of progress and continuous renewal" (Meyer 1998, p. 317). If linear conversions are linked to modernization narratives, then it is also worth noting that Western modernity is predicated, at least in part, on the Protestant Reformation. ${ }^{1}$ As Protestantism came to be distinguished from Catholicism, Catholicism came to be regarded as outside modernity-pre-modern or even anti-modern. In what Robert Orsi calls "the normative teleology of modernity", the premodern must yield to the modern in all areas of life (Orsi 2005, p. 156). Such a periodization itself, though, is reliant upon a non-repeating model of time. But this is a particularly modern model (Eliade 1954). As Jason Bruner puts it in his study of the persistence of non-Christian spiritual agents among Christian converts, such scenarios "require the historian not to assume a clear trajectory of progress, which is endemic to a modern, Western conceptualization of history itself" (Bruner 2019, p. 320). The idea of a trajectory from pre-modern to modern, from Catholic to Protestant, has come also to mean a trajectory from the nonlinear to the linear-a trajectory toward thinking of history as a trajectory.

One factor among others making it hard to acknowledge the nonlinearity of religious change, the oscillations and equivocation that frequently characterize conversion, is the scholarly bias toward Protestant (deemed modern) forms of religion. As Fenella Cannell argues, this normative Protestantism is rooted in Weberian assumptions about Protestantism displacing Catholicism and paving the path to secularism and capitalism (Cannell 2005, p. 341). The consonance of modern scholarship and modern religion may be in part why Pentecostalism-often classified as a form of Protestantism, but committed even more than mainline Protestant churches to the modernist ideal of breaking with the past-has attracted so much scholarly attention. ${ }^{2}$ Studies of Pentecostalism have exploded (no less than Pentecostal churches are said to), leading increasing numbers of Africanists to worry about the relative absence of attention to mainline Protestantism, African Initiated Churches, and Catholicism. ${ }^{3}$

Of course, in Africa and elsewhere, Catholic leaders have a long history of negating and denigrating local cultures, of demanding conversion in much the same terms that Pentecostal leaders do today. Yet there are significant strands of Catholic history to be explored in this paper that indicate or at least permit a more fluid and complex model of religious change. If Robert Strayer is right that "[t]here can be no linear description of modern African religious history which points to the steady erosion of traditional systems in favour of Christianity" (Strayer 1976, p. 10), we could better appreciate this complexity by looking "past Pentecostalism" (Engelke 2010) and indeed past Protestantism. It is especially the pronounced materialist and embodied strands of the Catholic tradition-the emphasis given to objects and practices-together with Catholicism's overall embeddedness in a deep historical past, that help to open analytical space for a less linear understanding of religious conversion in Africa.

What Orsi calls "the normative teleology of modernity" consists of numerous interconnected shifts. Each has been gradual, but also inexorable and by now definitive of what is taken to be the modern condition. Each also has deep roots in the Protestant Reformation. First is the shift of agency from things to people. Calvinist polemics against Catholicism entailed the denial of divine presence in material objects. The widespread dissemination of this view, beyond Protestantism and into secular modernity, informs contemporary judgments about proper, mature, or civilized religion. Such judgments take Catholic spirituality— "that array of practices, objects, liquids, images, ceremonies, and gestures by which Catholics had engaged the presence of God, the Mother of God, and the saints" (Orsi 2005, p. 154) — to be infantile, unhealthy, and backward. Modern religion involves immaterial meanings, propositional beliefs, and explanatory discourse. It involves a shift from bodily practices

1 As Fenella Cannell has written, "Insofar as [modernity] implies an irreversible break with the past, after which the world is utterly transformed in mysterious ways, it is itself modeled on the Christian idea of conversion" (Cannell 2006, p. 29).

2 Matthew Engelke has noted, "against the negative stereotypes of African culture and the African past, Pentecostals often define themselves as modern-as looking forward, not back, and as thus free from the chains of tradition" (Engelke 2010, p. 177).

3 See, for example, (Engelke 2010; Maxwell 2006, p. 392; Soares 2014, p. 28). 
and material mediations to the more intellectual, cognitive, or propositional properties of faith-"a shift form an ethos of presence and sacred intimacy toward a culture bounded by, and even obsessed with, words" (Orsi 2005, p. 157). Thus arises what anthropologist Talal Asad describes as the peculiarly "modern idea that a practitioner cannot know how to live religiously without being able to articulate that knowledge" (Asad 1993, p. 36), a world in which the cognitive and rational take precedence over the pragmatic and performative.

This shift away from a pre-modern understanding of a comingling of materiality and agency, of objects and subjects, accompanied a parallel shift away from a collectivist understanding of the self toward an individualist one. Here also the Protestant influence is clear. Agency among moderns rests properly in individual human subjects, not in objects and rituals, but also not in clerical or other social structures. As Webb Keane puts it, "At the heart of this version of the modern subject is the conjunction of personal and historical self-transformation with a vision of a self that must be abstracted from material and social entanglements" (Keane 2007, p. 55). There has been not only a conversion to modernity (van der Veer 1996) — that is, a cultural shift giving unprecedented primacy to individual agency-but also a modernizing of conversion. The early modern period witnessed an emerging sense that individual self-creation matters more than emplacing oneself within a social context or a historical tradition. There was, thus, a "devaluation of tradition in the name of historical progress" (Keane 2007, p. 201). With that devaluation, questions hitherto inconceivable came into being, questions such as "should I convert to another religion/no religion?" (Taylor 2009, p. 149). To convert in this sense from one religion to another is itself only possible with modernity. It is a possibility predicated on the severing of the self from material and social entanglements, the privileging of autonomous individuality over embedded sociality, and the concomitant devaluation of ties to deep pasts and historical traditions.

\section{Narratives of Reconversion}

In linear accounts of African conversion to Christianity and Islam, modernist assumptions are often presupposed-not just in the domain of political economy (as in Horton's theory that religious conversion and political modernization coincide), but also in terms of more fundamental shifts regarding religion and personhood: from a materialist to an intellectualist orientation and from a collectivist to an individualist one. Horton's theory of conversion, for example, is known as an intellectualist one which emphasizes religion as a tool for explanation, prediction, and control. Likewise, in her account of conversion to Seventh Day Adventism in Madagascar, Eva Keller reports among her informants a strong embrace of meaning-centered approaches to religion (Keller 2005). Importantly, both Horton and Keller describe conversion not only in intellectualist but also in linear, unidirectional terms.

By contrast, in many nonlinear accounts of conversion, "pre-modern" orientations—toward materiality and social connections, practice and pragmatism-predominate. It thus becomes noteworthy that, in Africa, stories of re-conversion-of gradual, fluid, and even oscillatory religious shiftsproliferate particularly in contexts where the self is understood to be embedded and entangled in material and social relations. Such embeddedness holds true of African societies generally, with their largely relational understanding of personhood, but even more so when the religions to (or from) which one is converting are themselves steeped in material, corporeal, and ritual dimensions.

Thus, many accounts of nonlinear conversion have to do with Islam and Catholic (more than Protestant) Christianity. Islam is focal in Aguilar's study of reconversion in Kenya (Aguilar 1995), in Michael Lambek's work out of Mayotte problematizing the category of conversion "insofar as it implies converting 'from' as well as 'to'" (Lambek 2000, p. 65), and Brian Peterson's preference for "drifting" over "opting" to emphasize the piecemeal nature of religious change in rural French Sudan (Peterson 2011). Catholicism is the relevant religion in Baum's study of "reconversion" in West Africa and in Paul Kollman's study of religious history in east Africa. In the latter, Kollman writes, "Religious identities can change, but conversion, with its emphasis on interior beliefs, misrepresents 
what usually happens, which is best understood at the level of practices" (Kollman 2005, p. 17). Switching from a paradigmatically Protestant preoccupation with beliefs to a more Catholic concern with practices brings complex patterns of entrance and exit into view-such as in Kollman's description of converts' pragmatic motivations, often having to do with labor conditions, for joining only to later flee Catholic mission stations. In his article on "Non-linear Conversion in a Gambia Borderland", Steven Thomson develops the critique of linear conversion models in slightly different ways, involving three traditions and transits between them (Thomson 2012). Yet here, also, it is telling that the religions under discussion are Islam and specifically Catholic Christianity, an indication again of the elective affinity between these two forms of religion and the materialist and socially/historically embedded orientation that demands a more dialectical model of religious change.

One must not be overly determinative, however, in associating Protestantism with singular allegiance and unidirectional conversion while associating Islam and Catholicism with fluidity and oscillation. Clearly, exclusive religious identities have been part of the story of African Catholicism (as I will touch on below) and African Islam (Fisher 1985, p. 165). Regarding Islam, Janet McIntosh, in her study based in Kenya, differentiates between Swahili versions of Islam and more porous versions prevalent among the ethnic Giriama. She describes the former along the lines I have been describing Protestantism: in terms of individual choice, intellectual beliefs, and inflexible religious affiliations. By contrast, Giriama traditionalists "often attempt to draw pragmatically upon the potency of more than one religious locus at a time, a pluralistic practice that dramatically violates the Swahili expectation that only one religion can have a monopoly on Truth" (McIntosh 2009, p. 20). What this shows is that the varieties of Islam in Africa are at least as great as the varieties of Christianity.

Moreover, numerous studies of Protestantism in Africa also describe conversion as a cyclical process rather than a linear progress. Perhaps the most well-known account of give-and-take between Protestant missionaries and indigenous Africans is Jean and John Comaroff's study of the "long conversations" (as opposed to sudden conversions) that transpired in southern Africa. The problem the Comaroffs raise with conversion as an analytical category is that it reifies "beliefs" and "belief systems", whereas those with whom the Comaroffs worked expressed a more fluid and relativist religious disposition, "not constrained ... by the notion that adherence to one religion excluded involvement in all others" (Comaroff and Comaroff 1991, p. 250). An objectification of such differences gradually emerged, with a more rationalist, intellectualist orientation supplanting this earlier pluralism, thus illustrating the power of Protestant missionaries to transmit a modern worldview to converts and non-converts alike. Yet, significant about the Comaroffs' study is the way that Protestantism did not immediately or automatically preclude non-Protestant-meaning nonlinear-ways of dealing with Protestantism.

In a similar vein, Birgit Meyer's study of Ghanaian (Ewe) converts to Protestantism demonstrates a link between materiality and porosity. Protestant missionaries' concern with an individual's state of mind was not shared by Ewe converts because of a fundamental difference in their conception of religion: "for the Ewe, religion could not be reduced to a state of mind, but was closely connected with everyday life. To them, it was not just a matter of belief but a praxis linking the ideal and the practical" (Meyer 1999, pp. 12-13). This practical orientation facilitated the same kind of dialectic observed by the Comaroffs in southern Africa. People returned to traditional priests when sick and unable to recover through Christian means (Meyer 1999, p. 104), a facility of reconversion owing to the fact that the Ewe did not conceive of religions as discrete systems of "belief". ${ }^{4}$ In all these accounts, what are emphasized are not the frameworks to which people convert, but the indigenous understandings that, along the lines in which Catholicism is often dismissively described, prioritize material entanglements, practical imperatives, and social embeddedness.

4 On the relationship between the reification of belief and the reality of religious pluralism, see also (Kirsch 2004). 
In his critique of continuity thinking in studies of religious change, Robbins accuses anthropologists of paying insufficient attention to the particularities of Christian models of time adopted by those who convert to Christianity (Robbins 2007). But by Christian models of time, Robbins means specifically Pentecostal or, more generally, Protestant models of time. If one starts with different models and emphasizes social and material concerns rather than narrowly intellectualist ones, the story may look quite different. My argument is that the qualities of religiosity especially associated with Catholicism and Islam differentiate both from Protestantism and provide conditions for the possibility of nonlinear conversions.

I do not mean to suggest too close an association, however. As with the Comaroffs' account of Protestantism, and as with McIntosh's account of Islam, the spur to a more circular pattern of conversion may be not the "world religions" to which but the indigenous baseline from which one converts. It cannot be said, therefore, that Islam and Catholicism are sufficient explanatory factors behind fluid religious identities. It is, however, noteworthy that when "re-conversions" occur, they are almost always for pragmatic and materialist rather than intellectualist reasons-and therefore, according to the typology presented above, for more "Catholic" than "Protestant" reasons. How precisely African Catholicism provides conditions for the possibility of such reconversions is the question to which I now turn.

\section{Retrieval and Renaissance in Catholic Thought and History}

Joel Robbins' analytic of rupture has been field-defining for the anthropology of Christianity, so influential that when David Maxwell questions, as have I, Robbins' "extreme emphasis on evangelical Protestantism", he does so on the grounds that African Catholics also instantiate radical disjuncture (Maxwell 2007, p. 26). Be that as it may, what of the possibility that Catholic perspectives open up a different analytic altogether (Hann 2017)?

In The Anthropology of Catholicism, editors Kristin Norget, Valentina Napolitano, and Maya Mayblin raise precisely this possibility — of a theoretical shift (beyond rupture) to accompany the empirical shift (beyond Pentecostalism). When it comes to Catholicism, they note, "continuity emerges time and again as an ethnographic concept in its own terms in the guise of 'tradition' - a value that derives partly from the theological principle of apostolic succession" (Mayblin et al. 2017, p. 5). Catholicism distinguishes itself from Protestantism through its strong sense of historical continuity. It is not so much about breaking with the past as it is about retrieving and reestablishing ties to Catholicism as an institution and to Catholicism as a historical tradition. Yet there is nothing dulling or deadening about such retrieval; it is not an act of passive reproduction (Bandak 2017). Rather, it entails an ongoing process of what Matt Tomlinson calls "transformative reengagement" (Tomlinson 2014, p. 166), a fittingly paradoxical expression that reveals continuity to be a labor-intensive project consisting of repetition and differentiation, preservation and change.

Throughout the world, Catholicism has exhibited this characteristic continuity not only with respect to its centralized institutional past, but also with respect to its diverse cultural contexts (see, e.g., (Orta 2004)). As a global religion, Catholicism makes claims to universality, and yet despite-or perhaps because of-doing so, it is able to accommodate competing ideas and brook compromises with local cultures (Hoenes del Pinal 2017, p. 171). Compromise became official policy during the Second Vatican Council (1962-1965), a moment of radical self-critique, of questioning earlier domineering attitudes toward non-Western cultures and non-Christian religions. Vatican II formalized mission principles such as "accommodation" or "adaptation", and through such documents as Lumen Gentium, Nostra Aetate, and Ad Gentes revolutionized modern mission theology. Although African religions went unmentioned in these documents (Isichei 1995, p. 327), the post-conciliar mood of liberalism, ecumenism, and pluralism led African bishops and theologians-albeit not without opposition, even from other African Church leaders- to make their contribution by theorizing and operationalizing "inculturation" and "incarnation" as conceptual alternatives to "adaptation" and its connotation of theological unity. Inculturation signals respect for customs and teachings 
considered to be aspects of Eternal Truth, even if foreign to the Christian tradition; incarnation signals the Church's willingness to immerse itself in African cultures, taking upon itself idioms, symbols, concepts, and other elements previously deemed foreign if not heathen. This shift in missionary approaches coincided with decolonization and cultural renaissance movements in most African countries (Hastings 1989, pp. 27-29). Out of that climate emerged a significant concern with searching out "authentic" African expressions of Christianity, with "Africanizing" the church. Although the top-down nature of Africanization efforts and the artifice of authenticity have been rightly problematized (Meyer 2004, pp. 454-55; Lado 2017), the significance of these efforts to establish cultural continuities with local contexts should not be minimized. They illustrate a capacity within Catholicism to connect with languages, cultures, and even religions at the grassroots. William Burrows writes that what he calls the "Catholic inculturation paradigm" is marked by "a radical vision of what is entailed in interfaith and cross-cultural dialogue that leads to the contextualization and inculturation of Christianity" (Burrows 1997, p. 131). According to this paradigm, not rupture but continuity is privileged-in this case, not (or not just) across time but also across cultures, and even across religions.

Of course, the Catholic Church was not always so accommodating of local cultural contexts; that it was often belligerent and hostile toward them is what made the Second Vatican Council so revolutionary. A tension has long existed in Catholic mission history between the impulse to assimilate and the impulse to adapt (Kollman 2005, p. 104). During the medieval and early modern periods, most dominant was what William Burrows follows missions historian David Bosch in calling the "missionary war" motif, the goal of which was "to lead non-believers to surrender to Christ and to create civilizations dominated by Christian values" (Burrows 1997, p. 124). This notion of missions-as-conquest manifested in hostilities toward Islam, most manifest during the Crusades, and antipathy toward indigenous cultures and other religions, most manifest during colonial expansion. At the level of culture and everyday life, it required a tabula rasa outlook, the notions "that there is nothing valuable in non-Western cultures upon which the missionary can build" and that missionary efforts must be as much to convey Christianity as to eradicate local religions, cultures, and ways of life (Sindima 1994, p. 62). The goal was not to transform non-European cultures and non-Christian religions, but to vanquish them, and then to introduce in their wake Western Christian values, norms, and habits.

In the realm of education, a prime site for the confluence of Christianizing and "civilizing" missions during the colonial period, students on the receiving end of missionary outreach were trained not only to speak like missionaries, to dress and pray like them, and to adopt names like theirs. More fundamentally, they were taught to rethink the nature of time and to know their place in the progression of human history. In his analysis of Catholic hymns introduced to the Dinka of Sudan in the late colonial period, Francis Deng notes schoolchildren began expressing, through song, contempt for "pagan priests", and the novel idea that they should "be ashamed of where they stood in the newly postulated scale of progress" (Deng 1988, p. 162). Yet, as shame-inducing as Catholic teachings were, the ideology of progress and development were far more intense in their secular forms. It is especially the postcolonial nation-state's teleology of development, Deng notes, that infringed on Dinka pride and sense of independence (Deng 1988, p. 169). As Godfrey Lienhardt, also working among the Dinka, argues, "the acceptance of the Church came through foreign secular ideas of progress and development for the most part material, which had little to do with the main evangelical purposes or teaching of the missions" ((Lienhardt 1982, p. 89); emphasis mine). By contrast, Lienhardt notes "a liberal tradition of Catholic thought which must recommend itself to those who find no authority in Christian teaching for condemnation of indigenous dancing and drinking, for example" (Lienhardt 1982, p. 86). ${ }^{5}$

5 In a similar vein, Brendan Carmody notes in Vatican II's shift away from the imperative to convert all non-Catholics to the Church an opportunity for Catholic education in Africa to return to its more holistic approach. However, it would be a return with a difference: not to be primarily an instrument of conversion, as before, but rather to be inclusive of the variety of students' religious affiliations and lived experiences (Carmody 2001). 
This more liberal Catholic tradition "presupposes a comprehension of "pagan philosophies'" (Lienhardt 1982, p. 86), connecting to classical antiquity in ways that again illustrate the themes of retrieval and continuity with the past that, as I have been arguing, also helped shape Catholic attitudes of respect for and continuity with "pagan" cultures of the present. The similarity becomes again apparent when one looks to early modern antecedents to Vatican II policies of accommodation and inculturation. Before the suppression of the Society of Jesus in the eighteenth century, many Jesuits in particular practiced an accommodational approach to missions. Matteo Ricci is perhaps the best-known example-a sixteenth century Jesuit who evangelized in China by first patiently and painstakingly studying its languages, philosophies, and religions in order to communicate Christianity through them, rather than impose it from above.

Here, also, openness to cultural continuity is tied to a deep sense of historical continuity. The exceptional nature of the Society of Jesus surely goes a long way toward explaining the accommodating spirit of early modern Jesuit missionaries. But also relevant may be the mostly Italian origins of those exemplifying what Alessandro Valignano, one such early modern Italian Jesuit, termed il modo soave - itself an Italian expression that elevated as missionary virtues sweetness and gentleness over hostility and aggression (Bevans and Schroeder 2004, p. 202). Besides Ricci and Valignano, one thinks also of Roberto de Nobili. Of course, one should not draw too direct a link between national origin and missionary attitudes. There were non-Italian Catholic missionaries, such as the Spanish Dominican Bartolomé de Las Casas, who campaigned for the rights of indigenous peoples of the Americas; other Iberian missionaries established reducciones in part to protect native Americans from slavers and conquistadores. Further, the founding Jesuit Francis Xavier (from Spain) and the missionary Alexander de Rhodes (from France) are often grouped with Ricci, Valignano, and de Nobili in recognition of their accommodational approach to missions. It is worth noting, however, that as inclusive and respectful as these latter were, there were also limitations not so apparent among Italians. Xavier "still basically followed the tabula rasa perspective-having contempt for Hinduism, Islam and traditional religion", at least initially (Bevans and Schroeder 2004, p. 185). For his part, when it came to Confucianism and ancestor veneration, de Rhodes "had a less appreciative attitude than Ricci and his fellow Jesuits in China" (Bevans and Schroeder 2004, p. 191).

This point about Italian provenance is relevant, given that in the early modern period, Italy (different from Portugal and Spain) was not engaged in overseas empire-building. Rather, the relevant context for early modern Italian missionaries is their upbringing in the incubator of the Renaissance, an intellectual and artistic movement that immediately preceded the onset of global Catholic missions. The Renaissance was about many things, but one of its central aims was to reconfigure the relationship between Christianity and pagan antiquity. It proposed a new appreciation for the Greco-Roman world, portraying it as a foundation for, rather than nemesis of, Christianity. It is thus relevant that Ricci and other Jesuit missionary pioneers "were greatly influenced by Italian humanism rather than by the Spanish conquistador environment", and considered the Asian civilizations to which they traveled to be analogs of the ancient Greco-Roman world ((Bevans and Schroeder 2004, pp. 194-95); see also (Ross 1994)). The Renaissance emphasis on historical retrieval shows, as does Vatican II's own revival of the methods of early modern Jesuits, how closely Catholicism's ability to establish continuities across cultures is tied to its sense of continuities across time.

\section{Reverse Missions in Mozambique}

In exploring what I argue is a proclivity for continuity in the Catholic tradition, I have dwelt as much as I have on the particularly Italian heritage of early modern Jesuit missions to set the stage for what I address in this article's final main section: the ministry of Giuseppe Frizzi, an Italian priest who has been working in Mozambique since 1987. Padre (Father) Frizzi belongs to an Italian Catholic missionary order called the Istituto Missioni della Consolata (Consolata Missionary Institute). It was founded in 1901 by Giuseppe Allamano of Turin, who is said to have taken inspiration for his missionary society from the example of Matteo Ricci. Born in Bergamo in the Lombard region 
of Italy, Padre Frizzi undertook seminary training in Rome around the time of the Second Vatican Council—the right place at the right time to launch him into the kind of ministry he would eventually undertake. His style of evangelization reflects well the new dispensation. Now in his seventies and still active in day-to-day ministerial responsibilities in Maúa district, he has indigenized the Catholic liturgy - conducting masses only in the local Makhuwa language. He has compiled both a Makhuwa-Portuguese dictionary and a Makhuwa ethnographic encyclopedia. He oversaw the revival of initiation rites after a period of state-ordered suppression, as well as the cultivation of Makhuwa art and artifacts (including the redesigned Catholic crucifix, described in this paper's introduction). He exudes an exceptionally sensitive, respectful, and deferential posture toward Makhuwa indigenous traditions-the languages, the culture, the religion. He is so widely respected that even members of the local Muslim population refer to him as "bambo ahu" (our priest, in the Makhuwa language).

Padre Frizzi's approach could be described as one of inculturation if not for the fact that he himself rejects the term. It does not go far enough, he has told me, as it is still top-down, premised on a hierarchical relationship. His interest is not only in introducing Christian truths in Makhuwa idioms, but also in rethinking Christian truths through the equally compelling truths of Makhuwa religion. Rather than inculturation, he speaks of "interculturation". ${ }^{6}$ He is interested in allowing his encounter with Makhuwa concepts, thoughts, and stories to awaken him to aspects of the Christian tradition that have been occluded, denied, or even absent over the course of its history. He is able to recover and revivify his own tradition by allowing himself to be witnessed to by those he came to witness to. In this sense, he is a kind of "reverse missionary", not in the conventional sense that scholars have come to use that term-for a person of the global South who spreads the gospel to Europe and North America. Rather, he is a reverse missionary in the sense of a foreign missionary willing to be learn from those he ostensibly came only to teach. ${ }^{7}$ This idea resonates with Padre Frizzi: in his scholarship in the area of Biblical studies, particularly regarding his specialty in the texts of Luke, Padre Frizzi writes explicitly of "the come-back mission" and "returned missionaries" (Frizzi 2010, p. 44), describing the missionary as one who operates retrospectively and "advances backpedaling" (Frizzi 2010, p. 38). Over the span of the nearly four decades that he has worked among the Makhuwa, Padre Frizzi has derived from their indigenous worldview nothing less than a revised understanding of God. ${ }^{8}$ As the Makhuwa, a matrilineal and matricentric people, refer to their supreme being (Muluku) as feminine and associate her with such ideals as companionship, cohabitation, and communion, so too Padre Frizzi has come to critique the traditionally Christian notion of God as autonomous and self-sufficient-and male. Those ideals are symbolized by the sun, as opposed to the moon. During the day, the moon and stars recede from view, which is why God-as Padre Frizzi claims to have learned from the Makhuwa-is more lunar than solar, more nocturnal than diurnal, more feminine than masculine (Frizzi 2010, pp. 26-27).

I suggest there are two salient points for understanding the dialogical nature of Padre Frizzi's missionary work. First is his Italian-nurtured appreciation for history, including classical antiquity - which Italians of his generation, particularly those training for ministry, were all deeply taught. Modernity in this context meant not a rupture from the past but a revivification of the present through the resources of the past. This legacy of the Italian Renaissance disabled a tabula rasa approach to "pagan" philosophies and cultures, and prepared Padre Frizzi to see value and virtue in cultures

6 For elaborations of the term interculturation, see (Shorter 1988, pp. 13-16); from the perspective of Consolata missionaries, including Padre Frizzi, see (Consolata Missionary Institute 2010).

7 For a critical overview of the discourse of "reverse mission", including an early definition having to do with learning from indigenous people and their leaders in the mission field and then advocating for their causes back in the missionary's home, see (Morier-Genoud 2018).

8 In this sense, Padre Frizzi can also be considered a comparative theologian (though he himself does not use this term) in the sense developed by Francis Clooney. Comparative theologians embrace vulnerability and risk by crossing over from their home tradition into another, later to return home with new and potentially destabilizing theological insights (see Clooney 2010). 
and traditions that are frequently, from Eurocentric and colonizing perspectives, despised. It prepared him to be a devotee and lifelong student of the linguistic and cultural wealth of the Makhuwa people.

The second point is Padre Frizzi's approach to multiculturalism and multilingualism. Here also there is a link to his Italian origins. Pride in the local appears to be common in Italy; it was, after all, relatively late in European history that it underwent political unification. But local pride especially characterizes Padre Frizzi's hometown of Bergamo. As David Gilmour notes in his survey of Italy's diverse regions, "many people in the Lombard town of Bergamo still refuse to speak anything other than bergamasco" (Gilmour 2011, p. 36). It is likely that Padre Frizzi's decision to devote himself to the study not only of Makhuwa but of specific Makhuwa dialects reflects Italians' own historical resistance to centralization. As Ian Linden notes in neighboring Malawi, most Catholic priests came from European peasant societies and were more devoted to the recreation of local communities than to modernist projects of unification and centralized control (Linden 1974). Padre Frizzi certainly fits that pattern, insofar as he himself hails from a small-town, dialect-speaking background, from which he gained a profound appreciation for the rural, the local, and the particular.

These are just two factors that shed some light on Padre Frizzi's unique style of evangelizing: his embrace of opportunities to be reconverted and reawakened by his engagement with the religious ideas and practices of the Makhuwa. I do not mean to imply that Padre Frizzi's approach to missions can be exhaustively explained by these factors, and it is of course the case that not all missionaries with such a background minister the way Padre Frizzi does; meanwhile, Catholic priests with other cultural backgrounds and orientations showed themselves also willing to rethink fundamental truths of the Christian tradition on the basis of their encounter with African practices and ideas. ${ }^{9}$ The point of laying out these issues is to provide context for understanding Padre Frizzi's ministry, not to provide an airtight explanation of it. I acknowledge also that it is possible to read Padre Frizzi's deep study of the Makhuwa language and his meticulous documentation of Makhuwa proverbs and practices as a ploy in service to his real objective: that of delivering converts to the one and only truth found in the Catholic Church and the Christian tradition. But this would be to miss that his very understanding of truth is itself informed by Makhuwa sensibilities that he described once, in conversation with me, in terms of their:

dynamism, movement, acceptance of alterity, more so even because of their oral culture that does not accept having everything fixed in place. Since childhood, the Makhuwa live this dynamism of speech, of dialogue, of not fixing things in place, of not reducing the truth to a written, linear dimension. The truth is always dynamic, always dialogic, with all the richness that writing lacks.

Here, incidentally, one also sees the importance of material and oral culture, Padre Frizzi's Makhuwa-inspired aversion to dominant cognitive and propositional approaches to faith-and, thus, in ways described earlier in this article, his aversion to Protestant-inflected modernity. This is the perspective that informed Padre Frizzi's sanctioning of the curvilinear crucifix and his valorizing of nonlinear ways of being and knowing in general. The nonlinearity with which Padre Frizzi describes Makhuwa epistemology befits, in turn, the nonlinearity of his own spiritual journey-his willingness to convert, in a sense, to Makhuwa wisdom traditions as a way of reconverting to his Christian faith.

To be sure, there are limits to Padre Frizzi's approach. One might fault him for reifying and essentializing a notion of "Makhuwa tradition" that, as he himself would recognize, does not lend itself to being codified in dictionaries and encyclopedias. However, it is precisely the epistemological construct of two disparate and relatively stable traditions-Makhuwa and Christian-that allows Padre Frizzi to move one step further than those who champion "inculturation", which, as the insertion of the Christian faith into a local culture, is ultimately a synthesizing and unifying move. As mentioned,

9 Some of the better-known examples among Catholic missionary priests in Africa include Placide Tempels (see Diagne 2016, pp. 25-27) and Charles de Foucauld (see Shapiro 1981). 
Padre Frizzi's preferred term is "interculturation" in recognition of the integrity of both sides in the exchange, and of both sides' (including Catholicism's) non-absolute status. He describes learning theological truths, even about Catholicism, from the Makhuwa as an achievement of "[c]ontinuity in discontinuity and otherness, empathic dialogue in giving and receiving that ends up in an exchange of gifts" (Frizzi 2010, p. 30). Missionary workfor Padre Frizzi is just such a process of going and returning, giving and receiving, with the missionary best described as one who "advances backpedaling". Conversion, thus, is ongoing. It is as nonstop and nonlinear as truth itself.

\section{Conclusions}

The aim of this article has been to think through a particularly significant aspect of the place where I conduct fieldwork - the local priest's openness to reconversion and a kind of reverse missionary project-by situating his work against the backdrop of Catholic understandings of continuity in Africa and elsewhere. To be sure, it is empirically dubious to bifurcate Catholicism and Protestantism into two essentially different spheres_one marked by materiality and continuity, the other marked by ideation and rupture. Ample counter-examples can be found on both sides (Brown and Feener 2017, p. 4). Nevertheless, I point in this paper to the importance of balancing anthropological studies of Christianity as a religion of rupture and discontinuity with lesser-known accounts of conversion that foreground such themes as retrieval and reconversion. The argument of this paper is that the study of Catholicism can be profitably marshalled to aid in this recalibration. As Robert Orsi writes with respect to the study of Catholic enchantment in a disenchanted academy, so too would I argue with respect to the study of Catholic nonlinearity in a linear academy: Catholicism invites us "to ask questions at odds with the assumptions and expectations of the intellectual disciplines of the modern world" (Orsi 2007, p. 40).

This article has emphasized the values of material and historical embeddedness in Catholic thinking and practice. I close by echoing what numerous scholars writing anthropologically about Catholicism have recently emphasized: the tradition's fundamental elasticity. Maya Mayblin has richly developed this idea, arguing in an article titled "The Ultimate Return" for an analytical distinction between "dissenting" and "being with dissent". She finds in Catholic practice a capacity for registering dissent without the need for the kinds of schism one finds throughout the history of Protestantism. Mayblin criticizes the degree to which a Protestant perspective has influenced Catholic historiography, leading to the privileging of institutional differentiation over dissent from within. This requires a more Catholic sensibility since, as Mayblin puts it, Catholicism seems to have "peculiarly elastic capacities when it comes to containing difference" (Mayblin 2019, p. 145). ${ }^{10}$

By virtue of its elasticity, Catholicism makes a particularly relevant topic of study for anthropologists insofar as Catholicism upholds, without too quickly dissolving, such tensions as that between the many and the one, the local and the global. Inculturation as a concept has been rightly criticized for its elitism and its tendency toward essentialism. Yet, in the long-term "interculturated" ministry of missionary priests like Padre Frizzi, one sees something slightly different: a more grounded, dialogical, and receptive approach that opens space for local perspectives and agency to be recognized and accepted. Though it is often said that Catholic attitudes toward local cultural traditions resulted from doctrinal policies designed at the Second Vatican Council, one might also consider the possibility that those policy shifts actually did not start in Rome and then radiate out to Africa and elsewhere.

10 Of course, Catholic history has not always lived up to this ideal, as the Church's efforts to suppress dissent, through inquisitions and investigations, amply attest. Yet this is what makes the Second Vatican Council so significant. As Adrian Hastings writes regarding Vatican II: "The Council's underlying emphases had been upon a greater freedom in the church, an admitted pluralism, a turning away from the uniformity not only of the Latin language but also of the very monolithic conception of 'the Latin Church', dominant in Pius XII's reign, to the fostering of a 'communion of churches' in which the particular characteristics of a 'local church', relating to a local culture, were to be encouraged rather than eliminated. All of this was as far away from the ultramontane presuppositions of many missionaries as it was from that of most of Rome's curial officials" (Hastings 1979, pp. 234-35). 
Rather than the center unilaterally shaping the margins, it may have been the margins also (perhaps primarily) shaping the center. The Makhuwa did not just convert to Catholicism. They converted Catholicism to themselves.

Funding: This research was funded by the Global Religion Research Initiative of the University of Notre Dame, grant number 262164EU.

Conflicts of Interest: The author declares no conflict of interest

\section{References}

Aguilar, Mario. 1995. African Conversion from a World Religion: Religious Diversification by the Waso Boorana in Kenya. Africa 65: 525-43. [CrossRef]

Asad, Talal. 1993. Genealogies of Religion: Discipline and Reasons of Power in Christianity and Islam. Baltimore: Johns Hopkins University Press.

Bandak, Andreas. 2017. Repeated Prayers: Saying the Rosary in Contemporary Syria. Religion 47: 92-110. [CrossRef]

Baum, Robert. 1990. The Emergence of a Diola Christianity. Africa 60: 370-98. [CrossRef]

Bevans, Stephen, and Roger Schroeder. 2004. Constants in Context: A Theology of Mission for Today. Maryknoll: Orbis Books.

Brown, Bernardo, and R. Michael Feener. 2017. Configuring Catholicism in the Anthropology of Christianity. The Australian Journal of Anthropology 28: 139-51. [CrossRef]

Bruner, Jason. 2019. Conversion and the Problem of Discontinuity in the East African Revival. The Journal of Ecclesiastical History 70: 304-21. [CrossRef]

Burrows, William R. 1997. A Seventh Paradigm? Catholics and Radical Inculturation. In Mission and Bold Humility: David Bosch's Work Reconsidered. Edited by Willem Saayman and Klippes Kritzinger. Maryknoll: Orbis Books, pp. 121-38.

Cannell, Fenella. 2005. The Christianity of Anthropology. Journal of the Royal Anthropological Institute 11: 335-56. [CrossRef]

Cannell, Fenella. 2006. The Anthropology of Christianity. In The Anthropology of Christianity. Edited by Fenella Cannell. Durham: Duke University Press, pp. 1-50.

Carmody, Brendan. 2001. Catholic Conversion and School in Africa Today. In Religious Conversion: An African Perspective. Edited by Brendan Carmody. Lusaka: Gadsden Publishers, pp. 159-78.

Clooney, Francis X. 2010. Comparative Theology: Deep Learning across Religious. Malden: Wiley-Blackwell.

Comaroff, Jean, and John L. Comaroff. 1991. Of Revelation and Revolution. Vol.1, Christianity, Colonialism, and Consciousness in South Africa. Chicago: University of Chicago Press.

Consolata Missionary Institute. 2010. Interculturality: New Paradigm of the Mission. Rome: Consolata Missions Edition.

Deng, Francis M. 1988. Dinka Response to Christianity: The Pursuit of Well-Being in a Developing Society. In Vernacular Christianity: Essays in the Social Anthropology of Religion Presented to Godfrey Lienhardt. Edited by Wendy James and Douglas Johnson. New York: Lilian Barber, pp. 157-69.

Diagne, Souleymane Bachir. 2016. The Ink of the Scholars: Reflections on Philosophy in Africa. Dakar: Council for the Development of Social Science Research in Africa.

Eliade, Mircea. 1954. The Myth of the Eternal Return, or Cosmos and History. Princeton: Princeton University Press.

Engelke, Matthew. 2010. Past Pentecostalism: Notes on Rupture, Realignment, and Everyday Life in Pentecostal and African Independent Churches. Africa 80: 177-99. [CrossRef]

Ferguson, James. 1999. Expectations of Modernity: Myths and Meanings of Urban Life on the Zambian Copperbelt. Berkeley: University of California Press.

Fisher, Humphrey J. 1985. The Juggernaut's Apologia: Conversion to Islam in Black Africa. Africa 55: 153-73. [CrossRef]

Frizzi, Giuseppe. 2010. Faith and Interculturality: Theology and Cultures. In Interculturality: New Paradigm of Mission. Edited by Consolata Missionary Institute. Rome: Consolata Missions Editions, pp. 23-44.

Gilmour, David. 2011. The Pursuit of Italy: A History of a Land, Its Regions, and Their Peoples. New York: Farrar, Straus, and Giroux. 
Gooren, Henri. 2014. Anthropology of Religious Conversion. In The Oxford Handbook of Religious Conversion. Edited by Lewis R. Rambo and Charles E. Farhadian. New York: Oxford University Press, pp. 84-116.

Hann, Chris. 2017. Reflections on an Anglophone Academic Sect. The Australian Journal of Anthropology 28: $242-47$. [CrossRef]

Hastings, Adrian. 1979. A History of African Christianity, 1950-1975. Cambridge: Cambridge University Press. Hastings, Adrian. 1989. African Catholicism: Essays in Discovery. London: SCM Press.

Hoenes del Pinal, Eric. 2017. The Paradox of Charismatic Catholicism: Rupture and Continuity in a Q'eqchi'-Maya Parish. In The Anthropology of Catholicism: A Reader. Edited by Kristin Norget, Valentina Napolitano and Maya Mayblin. Oakland: University of California Press, pp. 170-83.

Horton, Robin. 1971. African Conversion. Africa 41: 85-108. [CrossRef]

Isichei, Elizabeth. 1995. A History of Christianity in Africa: From Antiquity to the Present. Grand Rapids: W.B. Eerdmans.

Keane, Webb. 2007. Christian Moderns: Freedom and Fetish in the Mission Encounter. Berkeley: University of California Press.

Keller, Eva. 2005. The Road to Clarity: Seventh-Day Adventism in Madagascar. New York: Palgrave Macmillan.

Kirsch, Thomas G. 2004. Restaging the Will to Believe: Religious Pluralism, Anti-syncretism, and the Problem of Belief. American Anthropologist 106: 699-709. [CrossRef]

Kollman, Paul. 2005. The Evangelization of Slaves and Catholic Origins in Eastern Africa. Maryknoll: Orbis Books.

Lado, Ludovic. 2017. Experiments of Inculturation in a Catholic Charismatic Movement in Cameroon. In The Anthropology of Catholicism: A Reader. Edited by Kristin Norget, Valentina Napolitano and Maya Mayblin. Oakland: University of California Press, pp. 227-42.

Lambek, Michael. 2000. Localising Islamic Performances in Mayotte. In Islamic Prayer across the Indian Ocean: Inside and Outside the Mosque. Edited by David Parkin and Stephen C. Headley. Richmond: Curzon Press, pp. 63-98.

Lienhardt, Godfrey. 1982. The Dinka and Catholicism. In Religious Organization and Religious Experience. Edited by J. Davis. New York: Academic Press, pp. 81-95.

Linden, Ian. 1974. Catholics, Peasants and Chewa Resistance in Nyasaland, 1889-1939. London: Heinemann Educational. Maxwell, David. 2006. Writing the History of African Christianity. Journal of Religion in Africa 36: 379-99. [CrossRef] Maxwell, David. 2007. Commentary on Joel Robbins' ‘Continuity Thinking and the Problem of Christian Culture'. Current Anthropology 48: 25-26.

Mayblin, Maya, Kristin Norget, and Valentina Napolitano. 2017. Introduction: The Anthropology of Catholicism. In The Anthropology of Catholicism: A Reader. Edited by Kristin Norget, Valentina Napolitano and Maya Mayblin. Oakland: University of California Press, pp. 1-29.

Mayblin, Maya. 2019. The Ultimate Return: Dissent, Apostolic Succession, and the Renewed Ministry of Roman Catholic Women Priests. History and Anthropology 30: 133-48. [CrossRef]

McIntosh, Janet. 2009. The Edge of Islam: Power, Personhood, and Ethnoreligious Boundaries on the Kenya Coast. Durham: Duke University Press.

Meyer, Birgit. 1998. 'Make a Complete Break with the Past': Memory and Post-colonial Modernity in Ghanaian Pentecostalist Discourse. Journal of Religion in Africa 28: 316-49.

Meyer, Birgit. 1999. Translating the Devil: Religion and Modernity among the Ewe in Ghana. Edinburgh: Edinburgh University Press.

Meyer, Birgit. 2004. Christianity in Africa: From African Independent to Pentecostal-Charismatic Churches. Annual Review of Anthropology 33: 447-74. [CrossRef]

Morier-Genoud, Éric. 2018. 'Reverse Mission': A Critical Approach for a Problematic Subject. In Bringing Back the Social into the Sociology of Religion: Critical Approaches. Edited by Veronique Altglas and Matthew Wood. Leiden: Brill, pp. 169-88.

Orsi, Robert. 2005. Between Heaven and Earth: The Religious Worlds People Make and the Scholars Who Study Them. Princeton: Princeton University Press.

Orsi, Robert. 2007. When $2+2=5$. American Scholar 76: 34-43.

Orta, Andrew. 2004. Catechizing Culture: Missionaries, Aymara, and the "New Evangelization". New York: Columbia University Press.

Peterson, Brian J. 2011. Islamization from Below: The Making of Muslim Communities in Rural French Sudan, 1880-1960. New Haven: Yale University Press. 
Premawardhana, Devaka. 2018. Faith in Flux: Pentecostalism and Mobility in Rural Mozambique. Philadelphia: University of Pennsylvania Press.

Robbins, Joel. 2007. Continuity Thinking and the Problem of Christian Culture: Belief, Time, and the Anthropology of Christianity. Current Anthropology 48: 5-38. [CrossRef]

Ross, Andrew. 1994. A Vision Betrayed: The Jesuits in Japan and China, 1542-1742. Edinburgh: Edinburgh University Press.

Shapiro, Judith. 1981. Ideologies of Catholic Missionary Practice in a Postcolonial Era. Comparative Studies in Society and History 23: 130-49. [CrossRef]

Shorter, Aylward. 1988. Toward a Theology of Inculturation. Maryknoll: Orbis Books.

Sindima, Harvey. 1994. Drums of Redemption: An Introduction to African Christianity. Westport: Greenwood Press.

Soares, Benjamin. 2014. The Historiography of Islam in West Africa: An Anthropologist's View. The Journal of African History 55: 27-36. [CrossRef]

Strayer, Robert. 1976. Mission History in Africa: New Perspectives on an Encounter. In Religious Conversion: An African Perspective. Edited by Brendan Carmody. Lusaka: Gadsden Publishers, pp. 5-26.

Taylor, Charles. 2009. A Secular Age. Cambridge: Belknap Press of Harvard University Press.

Thomson, Steven. 2012. Christianity, Islam, and 'The Religion of Pouring': Non-linear Conversion in a Gambia/Casamance Borderland. Journal of Religion in Africa 42: 240-76. [CrossRef]

Tomlinson, Matt. 2014. Bringing Kierkegaard into Anthropology: Repetition, Absurdity, and Curses in Fiji. American Ethnologist 41: 163-75. [CrossRef]

van der Veer, Peter. 1996. Introduction. In Conversion to Modernities: The Globalization of Christianity. Edited by Peter van der Veer. New York: Routledge, pp. 1-21.

(C) 2020 by the author. Licensee MDPI, Basel, Switzerland. This article is an open access article distributed under the terms and conditions of the Creative Commons Attribution (CC BY) license (http://creativecommons.org/licenses/by/4.0/). 


\title{
Article \\ “We Stand for Black Livity!": Trodding the Path of Rastafari in Ghana
}

\author{
Shamara Wyllie Alhassan \\ School of Historical, Philosophical and Religious Studies at Arizona State University, Tempe, AZ 85281, USA; \\ shamara.wyllie.alhassan@asu.edu
}

Received: 1 June 2020; Accepted: 8 July 2020; Published: 21 July 2020

\begin{abstract}
Rastafari is a Pan-African socio-spiritual movement and way of life that was created by indigent Black people in the grip of British colonialism in 1930s Jamaica. Although Rastafari is often studied as a Jamaican phenomenon, I center the ways the movement has articulated itself in the Ghanaian polity. Ghana has become the epicenter of the movement on the continent through its representatives' leadership in the Rastafari Continental Council. Based on fourteen years of ethnography with Rastafari in Ghana and with special emphasis on an interview with one Ghanaian Rastafari woman, this paper analyzes some of the reasons Ghanaians choose to "trod the path" of Rastafari and the long-term consequences of their choices. While some scholars use the term "conversion" to refer to the ways people become Rastafari, I choose to use "trodding the path" to center the ways Rastafari theorize their own understanding of becoming. In the context of this essay, trodding the path of Rastafari denotes the orientations and world-sensorial life ways that Rastafari provides for communal and self-making practices. I argue that Ghanaians trod the path of Rastafari to affirm their African identity and participate in Pan-African anti-colonial politics despite adverse social consequences.
\end{abstract}

Keywords: Rastafari; Ghana; Jamaica; Pan-African; trodding the path; livity

\section{Introduction}

I thought my parents were crazy for most of my life. I am a Black Rastafari woman and I grew up in a small, predominantly white, rural town on California's Lost Coast. I could not understand why my parents wore African clothes, their hair in dreadlocks or why they believed so vehemently in the positive valuation of Blackness ${ }^{1}$ in an anti-Black space. To understand my parents, I would need to overstand ${ }^{2}$ the spiritual communities they came from. For the past fourteen years, I have interviewed at least two hundred Rastafari in Jamaica, Ghana, and Ethiopia. The work that I present in this article is a small articulation of a broader project on the intersections of Rastafari, nation, gender, and Pan-African politics in Africa and the Caribbean. Here, my concern is to discuss the reasons people become Rastafari in Ghana and how this decision affects their social, political, and economic outlook. I use a portion of my interview with one Ghanaian woman to illustrate the ways Rastafari engages her in the broader struggle for social justice. I argue that Ghanaians trod the path of Rastafari to affirm their African identity and participate in Pan-African anti-colonial politics, despite adverse social consequences.

1 I have chosen to capitalize Black, Blackness, and Black African to empower these identities in my work and lowercase white to disempower white identity and white supremacy.

2 Overstand is a Rastafari word that transforms the English term "understanding" so that the sound of the word matches the meaning. Under-standing, sounds like one is under the message being communicated and Rastafari believes that if one is under something, the message cannot be properly received, but if one overstands something, then they are able to receive the message and extend the meaning with their own thoughts or opinions. 
Rastafari is a Black Pan-African socio-spiritual movement, religion, and way of life ${ }^{1}$ that was created by Black working poor under British colonialism in 1930s Jamaica. Since at least the 1950s, Diasporan Rastafari have traveled to Ghana and other countries on the continent, and since the 1970s, Ghanaians began to trod the path of Rastafari. ${ }^{3}$ Informed by Ethiopianism, Pan-Africanism, Garveyism, Prophetism, and Back to Africa movements, Rastafari has burgeoned into a globalized way of life. ${ }^{4}$ Rastafari lifeways center Africa and decenter Europe as an epistemic frame of reference, propagate I-and-I consciousness (which is the notion that all human beings are connected through individual and collective divinity), and work toward the radical dismantling of all structures of "Babylon." 5 Rastafari's fundamental contributions in the twenty-first century continue to center Africa, create a new Black beauty aesthetic, form anticolonial lived realities, offer a gender critique that advances the balance of male and female energies, ${ }^{6}$ and radically assert humanity for all Black people by making Emperor Haile Selassie I and Empress Mennen of Ethiopia divine. ${ }^{7}$

Exploring the ways travel and spirituality shape political solidarities amongst Diasporan and Ghanaian Rastafari enables theorizations about the ways people create anti-oppressive communities in the spirit of African Unity. The ability of Rastafari to build community across race, culture, language, gender, and nation has recently become a node of exploration for Rastafari Studies in continental Africa. ${ }^{8}$ Horace Campbell ${ }^{9}$ called for a shift away from simply studying the theology and symbols of the Rastafari movement in Jamaica or the Caribbean and instead argued for an explicit focus upon the ways Rastafari articulates itself in social, cultural, and political spheres. ${ }^{10}$ Monique Bedasse has called for scholars to engage with Rastafari travelers as central to the global reach of the movement and not just cultural iconography or reggae music. Continental Africa is a fruitful terrain for thinking about the social and political experiences of Rastafari. With the 2018 formation of the Rastafari Continental Council there is an urgency within the movement to enact and operationalize the Africa-centered cosmogony that galvanized the movement from the 1930s.

With special emphasis on the ethnography of one Ghanaian Rastafari woman, this paper analyzes some of the reasons Ghanaians choose to "trod the path" of Rastafari and the long-term consequences of their choices. While some scholars use the term "conversion" to refer to the ways people become Rastafari, ${ }^{11}$ I choose to use the notion of "trodding the path" to center the ways Rastafari theorize their own understanding of becoming. The concept of conversion is deeply embedded in the histories of Christian and Islamic domination in Africa and elsewhere. ${ }^{12}$ Even when the concept is not explicitly tied to these histories, it commonly denotes a Euro-centered and scripto-centric understanding of religion. While I appreciate the innovative notions of conversion that discuss the concept as a form of self-transformation, ${ }^{13}$ I do not think the conceptual category of conversion is adequate to account for

(Middleton 2006; White 2007, 2010; Bonacci 2015; Augier and Salter 2010).

(Edmonds 2012; Bonacci 2015)

"Global capitalism, which extracts resources from less developed countries, exploits the labor of the working class, and disproportionality enriches those individuals and countries that control capital, constitutes a contemporary manifestation of Babylon" (Edmonds 2012), pp. 39-40. Babylon can also denote policing, incarceration, the media, or any other tool used for the purpose of domination. Please see Horace Campbell, Rasta as Resistance, pp. 211-16.

6 This is true when we consider Rastafari women's thoughts specifically.

7 Emperor Haile Selassie was the last Emperor of Ethiopia, he was the first African leader to speak before the League of Nations in 1936.

8 Homiak (2013) argues that Carole Yawney theorized Rastafari as a "traveling culture," because of the movement's unique ability to maintain its heterogeneity and to translate to multiple spaces. The notion of traveling cultures borrows from James Clifford's theorizations.

9 (Campbell 1987, 1988).

10 Ibid.

11 (Chevannes 1994; Price 2009).

12 Please see (Olupona 2013).

13 Please see (Price 2009). 
the religious and spiritual experiences of Rastafari, because this is not the language they would use to overstand themselves. ${ }^{14}$

Most scholars of Africana religions use the terms initiation or homecoming to signal the ways Africana religious practices help them reveal more of their authentic selves and find spiritual community. Epistemic racism ${ }^{15}$ has denied scholars the ability to always foreground the language, categories, and theorizations of Black people. I explicitly choose to use the language, categories, and theorizations of Rastafari people to understand their spiritual and religious lives. Rastafari use the terms trodding the path, inborn concept, visions, and light to discuss the ways they became Rastafari. In the context of this essay, trodding the path of Rastafari is not a euphemism for conversion. Instead, it centers the epistemic categories and theorizations Rastafari use to understand themselves. Trodding the path denotes the orientations and world-sensorial ${ }^{16}$ life ways that Rastafari provides for communal and self-making practices.

\section{A Personal Perspective of Trodding the Path in Takoradi, Ghana}

Driving through the balmy Cape Coast heat to Takoradi in the Western Region of Ghana during the summer of 2017 was like a homecoming. We passed plantain trees and rich vegetation on the sides of the winding road. My husband, 6-month old son, and I were going to visit Sista Pama. Sista Pama was initially introduced to me as one of the only Rastafari women in Takoradi by a mutual friend. However, that was nine years ago, and I was excited to learn how things might have changed since I last saw her in person. We met at Montego Bay, her vegan restaurant and juice bar. She named it after the city in Jamaica where her mother lived for about sixteen years. The connections between Jamaica and Ghana have been long established through diplomatic and cultural relationships and the recent alleviation of visa requirements for both Jamaican and Ghanaian nationals. ${ }^{17}$ Rastafari has engendered these African and Caribbean cross-cultural connections through travel, music, and Pan-African politics. ${ }^{18}$

As we drove up to Montego Bay, we saw Sista Pama standing on the patio that served as an entrance to the restaurant. Her locks were longer than I remembered, and we alighted from the car and hugged her. Like most of the Rastafari women I interviewed, she took my son from me and sat down to play with him while we set her up with a microphone for our interview. Sista Pama is a strikingly beautiful golden-brown Ghanaian woman who was a TV personality when we first met in 2008. While she no longer had her TV talk show in 2017, her radio show and restaurant were going strong. When I asked her how she began to trod the path of Rastafari, she said, "Well, I actually started trodding the path of Rastafari at a radio station. I got this job and they told me they wanted to play reggae."19 She began to listen to the music lyrics and read more about the movement that produced the music. ${ }^{20}$ As she learned more about Rastafari, she was drawn to the positive Black African consciousness of the movement. She learned mostly on her own because there was not a big community in Takoradi. When she began to trod the path of Rastafari, her family was fine with her choice, but her community began to say things like, "'You are going mad.' 'You are now smoking weed.' 'Maybe you found yourself a Rasta boyfriend.'"21 She did not pay attention to those disparaging remarks because she was so focused on her own self-making journey. Other Ghanaian Rastafari women

14 During fourteen years of ethnography, I have yet to meet Rastafari that would describe the way they became Rastafari using the term 'conversion' or 'convert.' This is not to say they do not exist, but it is to say I have no empirical data to support the widespread use of the term.

15 Please see (Diakité and Hucks 2013, pp. 28-77).

16 (Oyěwùmí 1997).

17 Ghana, Jamaica Waive Entry Visa Requirements for Citizens BY: graphic.com.gh: https://www.graphic.com.gh/news/generalnews/ghana-news-ghana-jamaica-waive-entry-visa-requirements-for-citizens.html.

18 (Bedasse 2017).

19 Sista Pama, in discussion with the author (in Takoradi, Ghana), July 2017.

20 Most Ghanaians learn about Rastafari through reggae music. Please see (Middleton 2006; White 2007, 2010).

21 Sista Pama, in discussion with the author (in Takoradi, Ghana), July 2017. 
had similar experiences of discrimination. In an interview, Sista Agnes, discussed the way people thought she was insane and endangered her children because she locked their hair and raised them Rastafari. Mama Zion recounts the way people put their hands in her dreadlocks to see if her hair was real and assumed she was a foreigner even though she was born in Ghana. In fact, most Ghanaian Rastafari share that Diasporan Rastafari are more accepted than they are because it is assumed that Rastafari is a tradition for Diasporans and not Africans. One of the ways Ghanaian Rastafari are accepted in mainstream society is through the entertainment industry or if they go abroad and then come back to Ghana. These very narrow modes of social mobility prevent some people from growing dreadlocks or outwardly proclaiming their Rastafari identity. For example, Sista Agnes's husband decided not to grow dreadlocks so he could keep his job, but he still identifies as Rastafari.

One of the most important reasons people choose to become Rastafari is the movement's valuation of Black Africanness and its Pan-African anti-colonial politics. ${ }^{22}$ While there is a perception of Rastafari as foreign in terms of mainstream Ghanaian society, Ghanaian Rastafari think of the movement as African. African identity has been central to Rastafari belief systems, even in Jamaica. Most Jamaican Rastafari identify as African. Due to pervasive anti-Black racism and global white supremacy, the foundational Rastafari valuation of Black African identity and their continued fight for Black liberation and against all forms of oppression have galvanized aggrieved populations globally. Like Jamaica, Ghana was colonized by the British and this colonial process came with adverse psychological, cultural, religious, political, and economic impositions, which transformed the ways race, color, and indigenous African cultural practices were valued. ${ }^{23}$ Ghanaian political leaders and scholars like Osageyfo Dr. Kwame Nkrumah, ${ }^{24}$ Ayi Kwei Armah, ${ }^{25}$ Ama Ata Aidoo, ${ }^{26}$ and others have fought against neocolonialism and white supremacy and for the valuation of Black African knowledge systems. This Pan-African anti-colonial stance is amplified by the Rastafari movement because it captures the imagination of some segments of the Ghanaian population that desire a way of life that reflects their love of Black aesthetics, their fight for African unity, and their desire to affirm their precolonial African traditions and divinities. Although Rastafari has augmented Pan-African praxis in Ghana, the movement is stigmatized locally and internationally as mad or insane.

While the choice to become Rastafari leads to personal affirmation and access to an international community, it does not always translate into greater social and economic mobility in the broader societal context of Ghana due to stigma associated with the Rastafari movement. ${ }^{27}$ Historically, Rastafari purposefully embraced non-normative lifestyles and many took a militant or adversarial stance toward broader social structures upholding neo-colonialism and white supremacy, therefore Rastafari are prepared for adversity when they choose to trod the path. Ghanaian Rastafari overstand the risk associated with their choice to become Rastafari, but their commitment to joining an international community fighting for Black liberation and African unity outweighs the personal risk of losing friends, family, and economic viability. Sista Pama's ability to gain employment in radio and television was possibly due to more opportunities in the entertainment industry. Rastafari have often been able to gain employment as entertainers or in the tourist industry, but beyond these places of employment, many find significant obstacles. While much of the stigma associated with Rastafari has changed over time, brethren and sistren continue to experience challenges to social, political, and economic integration. Some of the Rastafari that I have worked with have been ostracized from their communities, plagued by chronic unemployment, forcibly committed to mental asylums, or unable to have a family because

\footnotetext{
(Price 2009).

(Pierre 2013).

24 Kwame Nkrumah was the first Prime Minister and President of Ghana. His revolutionary activism helped found the Organization of African Unity, which led to the creation of the contemporary African Union. One of the many groundbreaking books he wrote was: (Nkrumah 1965).

25 (Armah 2002).

26 (Aidoo 1977).

27 (Dovlo 2002).
} 
they are deemed undesirable partners. Despite adverse social consequences, becoming Rastafari is one avenue for Ghanaians to embrace decolonial Pan-African politics.

Sista Pama found positive affirmations of herself as an African woman through studying Garveyite philosophy and the Pan-African work of Emperor Haile Selassie and Empress Menen of Ethiopia. This positive valuation of Africanness allowed her to assert her decolonial practice with righteous conviction rooted in Black livity. Livity is a Rastafari concept that means lived philosophy. Livity guides the daily practice of decolonization that Rastafari undertake to free themselves from colonial and white supremacist anti-Black racism and center Pan-African liberation. When a person chooses to trod the path of Rastafari, she takes a non-normative path, particularly in environments where neocolonialism and white supremacist indebtedness to Eurocentrism are still the dominant purview. Sista Pama defies expectations by wearing African clothing and her natural hair and decentering Europe as a primary frame of reference. Although aware of the adverse social consequences, when we went to see Sista Pama, she spoke at length about how she has benefited from her choice to trod the path of Rastafari.

You know when you start to study the philosophies of Marcus Garvey and you learn about Emperor Haile Selassie and Empress Menen, you get a deeper understanding and a deeper knowledge of what you are doing. We are still learning, but now we are deep rooted and grounded and so we can stand firm and speak our minds freely. And tell them "A, this is it! We stand for truth and right! We stand for righteousness! We stand for Black livity! And we are very spiritual." 28

In this quote, Sista Pama reveals an important aspect of Rastafari livity: studying. Reading the philosophies of different Pan-African figures fortified and deepened her knowledge of Rastafari and allowed her to speak confidently about her Black spiritual politics. Her feeling of confidence allowed her to proudly proclaim, "we stand for Black livity," which became the title for this article. Ultimately, the more she read about African history and positive valuations of Blackness, the more empowered she became in who she was as a Black African woman. Therefore, Rastafari helps her to decolonize white supremacist anti-Blackness, reveal her authentic self, and be confident in her African consciousness. Despite social ostracism, the deep reading and knowledge seeking Rastafari engage in fortifies their embrace of Pan-African Rastafari philosophy and allows them to remain stalwart in their convictions. Charles Price ${ }^{29}$ has written extensively about the stigma people in Jamaica experience when they choose to become Rastafari and the ways this stigma helps affirm their choice rather than function as a deterrent. Ghanaian Rastafari are often discriminated against both in their homes and in their communities, because they eschew dominant interpretations of Christianity, which is the majority religious practice in Ghana. ${ }^{30}$ While there is a long way to go before there can be complete acceptance of Rastafari, the movement has become part of the fabric of Ghanaian history in terms of Rastafari activism in mainstream political, environmental, and social spheres in Ghana.

Ultimately, Sista Pama's choice to trod the path of Rastafari and endure the stigma associated with her choice is due to her commitment to the valuation of Africanness. Although the Rastafari movement began in Jamaica, she identifies it as an African way of life. She sees Africa as a Pan-African geography that is not only tied to land, but also tied to Black identity.

[Rastafari is] an African way of life. It will never be Jamaican because even in Jamaica, Jamaica is still Africa. Black people are living there. And wherever Black people are, it's Africa. You can be overseas, wherever you find yourself, but if your skin is black, you are an

28 Sista Pama (Rastafari woman in Takoradi, Ghana), in discussion with the author, July 2017

29 (Price 2009).

30 While Christianity is introduced to Ghana through slavery and colonialism, there have been many movements such as the African Independent Church movement to indigenize Christianity. Thus, Rastafari is not the only mode through which people reclaim their African heritage. 
African. It's an African livity. You live it. It is not something that you can just do anyhow. It's an everyday thing like you wake up in the morning and you know you are supposed to brush your teeth. It's a livity, you live it, that's it.

For Sista Pama, being Black becomes central to overstanding her African identity. Nationality notwithstanding, Blackness shapes and articulates the decolonial politics that are expressed through livity. In addition to deep reading and seeking knowledge, the other important aspect of Rastafari livity is choosing to embrace a positive Black African identity every day. There are constant reminders of anti-Blackness that are pervasive in Ghana, whether it be the Spanish or East Indian TV soap operas that reinforce white beauty standards, bleaching creams that are sold openly in the market, or the social emphasis on learning more about Europe and the United States than other countries in continental Africa, these are just some of the few ways anti-Blackness can permeate a majority Black country. Choosing to embrace Blackness and read more about Black history allows Rastafari to consciously dismantle anti-Blackness. Sista Pama emphasizes that choosing to affirm Blackness must be conscious and happen daily. Her constant choice recognizes both the urgency and long-term political commitment that fighting for Black liberation and the valuation of Africanness entails. Her entrepreneurial endeavors align with her Rastafari consciousness. There are not many vegan restaurants in Ghana and many non-Rastafari Ghanaians view meat as an important staple of a meal. By opening Montego Bay, she introduces Takoradi to diverse food options which actively support the Rastafari notion of decolonizing the body through consuming healthy vegan plant-based food and drink. On her radio show, she plays reggae music and Ghanaian reggae artists in order to support local artists and the Pan-African lyrical content. In her personal life, she is mindful of the types of images of Africa her daughter consumes and actively teaches her daughter Black history and many of the Pan-Africanist figures in Africa and in the African Diaspora. Through her business, radio, and mothering, Sista Pama creates a space in Takoradi for the elevation of Black consciousness, Black liberation and Rastafari livity. When she first began to trod the path of Rastafari, people were weary of her because they did not understand what she was doing; now people gravitate towards her and actively want to know more about why she lives the ways she does. Ultimately, Rastafari has helped her become part of a broader international Black community that has fortified her even during the most difficult times.

While Sista Pama is not part of a particular mansion ${ }^{31}$ in Rastafari, her comments index the broader cultural and intellectual impacts Rastafari has had in Ghana through organizations like the Rastafari Council of Ghana, which is the umbrella organization that represents individual Rastafari mansions ${ }^{32}$ and organizations in the country. Ghana has become an epicenter of the movement on the continent through the creation of the Rastafari Council of Ghana, the launching of the Black Star Line Cooperative Credit Union in 2009,33 (which is one of the only Rastafari owned banking systems in the world), and the 2018 Rastafari Continental Council (RCC) election of Ghanaian Ahuma Bosco Ocansey (Daddy Bosco) as president. The RCC is the governing arm of the movement on the continent. Through national conferences, symposia, news articles, as well as other venues, these organizations advance their Pan-African agenda, which not only includes affirming African identity, but advocating for economic justice, environmental sustainability, and political enfranchisement. In 2014, the Rastafari Council of Ghana organized, alongside Food Sovereignty Ghana and other environmental groups, to place an embargo on the importation of GMOs; in 2015, they implored the Ghanaian government to

31 Mansions or houses are the Rastafari terms for organizations within the movement. These organizations differ ideologically and in practice. The three central organizations within Rastafari are the Nyahbingi, Twelve Tribes of Israel, and the Ethiopia-Africa Black International Congress.

32 Please see footnote 22 on why I use the term mansions.

33 The Black Starline Cooperative Credit Union was named after the Black Star Line, a shipping company that Marcus Garvey and the United Negro Improvement Association (UNIA), created in 1919 to transfer goods and repatriate people back to Africa and assist in attaining economic justice for Black people globally. Marcus Garvey's legacy and the notion of the Black star is also a prominent symbol of Pan-Africanism in Ghana with the Black star featured prominently in the Ghanaian flag and Kwame Nkrumah's admiration of Garvey. 
issue a solidarity statement in support of Palestinian sovereignty; in 2020 Rastafari spearheaded the movement to decriminalize cannabis, which won a small victory this year but remains a contentious issue. By engaging national discourses, the Rastafari Council positions itself as a major actor in the Ghanaian polity and extends itself beyond stigmatized particularity. The thwart refusal of Rastafari to be dismissed from the public sphere is part of their radical reclamation of space to advance their Pan-African agendas. The gains the Rastafari community in Ghana has made in recent years can only be understood in the larger frameworks of the Ghanaian polity, ideas of Pan-Africanism, and the heterogeneous cross-cultural development of Rastafari philosophy itself.

\section{Trodding the Path of Rastafari in Ghana's Religious Publics}

Although many scholars emphasize the Judeo-Christian basis for Rastafari philosophy, some have argued there is an over emphasis on Western notions of Christianity and not enough research concerning the ways traditional African spiritualities provide core foundations for Rastafari. ${ }^{34}$ Everything from the notion of a Black God, ${ }^{35}$ marijuana as holy sacrament, and dreadlocks to reggae music, Pan-Africanism, and aspects of the Hebrew bible have roots in African cultural, spiritual, and political practices. ${ }^{36}$ Maureen Warner-Lewis ${ }^{37}$ details the continuities between Akan traditional spirituality in Ghana and Rastafari. In her essay, "African Continuities in the Rastafari Belief System," Warner-Lewis writes that a belief in human beings as divine is fairly common throughout West African societies and that Kings and Queens normally represent this divinity. Thus, Emperor Haile Selassie's divinity can be rationalized not only through biblical lineage, but also through West African cosmologies. The Rastafari notion of the self as a spirit being that lives eternally, is also a common notion in West Africa. ${ }^{38}$ The self in the spiritual dimension of life is underscored by the Rastafari concept of eternal life. Rastafari practitioners proclaim, "Rasta cannot die." ${ }^{39}$ Beyond a purely biological conception of being human, there is an eternal living state of being that exists in the spiritual dimension. This concept of the human as spiritual and connected to a universal metaphysical force that incorporates the ancestors and all living things is a basic conception in Rastafari. ${ }^{40}$

Finding connections between Rastafari and African continuities of thought in the Caribbean is significant because Rastafari not only imagines Africa and views Africa as coeval politically, but spiritually retains world-senses that are direct continuities of sacred African knowledge systems. However, as Elom Dovlo ${ }^{41}$ points out, African traditional religion is constantly changing and sometimes when Rastafari seek “... spiritual and cultural roots in African Traditional Religions, often, they discover that the traditional spirituality they seek, though available, is not always openly accepted by westernized and Christianized Africans they come into contact with." 42 The tension between Ghanaian religiosity and societal stigma is disconcerting to Diasporan Rastafari who journey to Ghana and Ghanaian Rastafari who begin to trod the path in search of ancestral and spiritual renewal. In

34 (Savishinsky 1998, pp. 140-41).

35 It is important to note that the concept of a Black God comes from a variety of Africana Religions and is not just a province of Rastafari or continental Africa. Notably, the African American Christian Religious tradition from Albert Cleage Jr. to James Cone has cast God as Black and Christ as Black. This notion of Black divinity ultimately supports the notion that Black people are human beings.

36 Savishinsky uses compelling anthropological data from a variety of African ethnic groups, mostly from central Africa, as evidence for his arguments.

37 (Warner-Lewis 1993, pp. 108-23).

38 Divinity is therefore conceptualized as self-created and self-perpetuated, outside of Man, but on another level. It is also conceptualized as incorporating culture-heroes together with the accumulated spirit-force of human ancestors ... Given the innate godliness of Man-Man cannot die ... Life is thus conceived not only as a biological state. It has a spiritual dimension as well. Hence the paradoxical belief that spirit being the full realization of human potential and is a more powerful state than temporal existence (Warner-Lewis 1993, pp. 112-13).

39 (Chevannes 1994).

40 (Owens 1976; Salter 2008)

41 (Dovlo 2002).

42 Ibid. 
fact, the stigmatization of African traditional religious practices and Rastafari is similarly articulated due to the comparable aesthetic appearances of Rastafari and African Traditional priests. ${ }^{43}$ Darren Middleton writes, "It seems highly likely that some of these early Rastas noted the similarity between the appearance of Rasta celebrities like Bob Marley, with his long matted hair, and traditional African fetish priests and, therefore, perceived Rastafarianism as an authentically African way of life ... More than a few non-Rastafarian Ghanaians remarked to me that with the emergence of Rastafarianism among Ghanaian youth in the mid-to-late 1970s, fetish priests found a wider audience for their words and deeds." 44 The renowned fetish priest, Okomfo Anokye, who many say brought the golden stool from the sky that has become the life force of the Asantehene, ${ }^{45}$ has a statue in Kumasi that depicts his cowrie shell studded dreadlocks. The relationship between Rastafari and African traditional spirituality creates new spaces for sharing and exchange in the spiritual publics of Ghana, but it has also meant shared stereotypes and stigma.

Ghana remains a predominantly Christian country, with a strong Muslim community and a smaller community that practices African indigenous religion. Some Muslims in Ghana also practice Rastafari and call themselves Rasmuslims. While Rasmuslims are not necessarily changing the practice of Islam, they use the Quran to rationalize Rastafari beliefs and aesthetics. Rastafari evolves through a Black circuit of ideas and thus the heterogeneity of spiritual beliefs and practices comprising Rastafari in West Africa are constantly changing according to the needs, contexts, and histories of the people. ${ }^{46}$ Africana religions are utilitarian in that people draw from the spiritual and religious traditions and healing methods that they need in order to achieve their goals. Within Rastafari, the fight for Black liberation is central to overstanding its overall spiritual cosmogony and appeals to Ghanaians who achieved the political kingdom in 1957 through independence from Britain but are still fighting to decolonize religiously, psychologically, and economically. Through livity, or daily acts of decolonization of food, language, dress, and reasonings or extended spiritual conversations around race, politics, and building a new egalitarian world, Rastafari opens up epistemic and spiritual spaces for diverse groups to build anti-oppressive societies and fight for Black liberation. ${ }^{47}$

Dovlo ${ }^{48}$ argues that neo-religious, political, and cultural movements come to Ghana seeking a route home, and this route is augmented by Sankofa movements that seek to spiritually and politically return Africans to the source of their own human dignity. He writes, "Ghanaians can identify with the call to return to culture. This has been part of the cultural policy of governments since independence. It is currently espoused and popularized in the concept of 'Sankofa.' Apart from its artistic manifestation such as in clothes, theatre, music etc., there is a deep longing for the traditional sense of community as pertained in the past." ${ }^{49}$ Movements like Rastafari inspire some Ghanaians on their own anti-colonial journeys. However, while many youth or people already outside social norms may join these movements, they are still subject to increased social precarity.

\section{The Rastafari Trod Is a Constant Choice: Considerations for Future Scholarship}

We left Sista Pama's Montego Bay vegan restaurant and juice bar enriched and thankful for the time she shared with us. The landscape in Ghana has transformed in the nine years that I have known her. She remarked that now many Ghanaian women and girls admire her dreadlocks and want to learn more about Rastafari. When I first met her in 2008, dreadlocks were still definitively connected to African traditional priests and were heavily stigmatized. While in Ghana in 2017, I noticed an

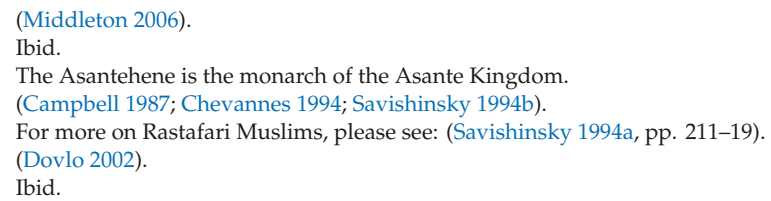


increase in hair salons catering to natural Black hair and natural hair expos where dreadlocks were a featured hairstyle. The former First Lady of Ghana, Lordina Mahama and the current Minister of Communication and Technology, Hon. Ursula Owusu-Ekuful wear their hair in dreadlocks and employers, beyond the entertainment industry, have begun to accept employees with the hairstyle. Many of the people wearing dreadlocks are not necessarily Rastafari, but their embrace of the hairstyle represents the broad-based cultural influence of both African traditional spirituality and Rastafari. These promising transformations signal that the movement's development over time will be important to watch in terms of the ways Rastafari is able to influence the religious and Pan-African publics of Ghana.

The choice to trod the path of Rastafari is complex both for the individual and for the community as a whole. By centering the language of trodding the path, this article centered the categories that Rastafari people have used to think about their lives and their practices. Epistemic racism still shapes the reasons some scholars continue to employ Eurocentric conceptual categories and frameworks to overstand the experiences of Africana people. Through individual narratives, such as Sista Pama's, or the work of the Rastafari organizations, the movement on the continent is producing important and innovative ways of thinking about contemporary Pan-African consciousness. Considering Rastafari in Ghana opens a space for questioning the way religion is understood in West Africa, the disciplinary divisions between Africa and the African Diaspora, and the way nation, imperialism, and neo-colonialism still work to construct impediments in the lives of brethren and sistren. The personal self-making practices engendered by Rastafari, provide new avenues for considering how people employ Rastafari as a framework for asserting human dignity and advancing the cause for African Unity. These self-making and community building practices fashion new realities for people choosing to trod the path of Rastafari in the Ghanaian polity.

Funding: This research received no external funding.

Conflicts of Interest: The authors declare no conflict of interest.

\section{References}

Aidoo, Ama Ata. 1977. Our Sister Killjoy or Reflections from a Black-eyed Squint. London: Longman.

Armah, Ayi Kwei. 2002. KMT In the House of Life. Popenguine: Per Ankh Pub.

Augier, Roy, and Veronica Salter. 2010. Rastafari: The Reports. Kingston: Caribbean Quarterly, Cultural Studies Initiative, UWI.

Bedasse, Monique A. 2017. Jah Kingdom: Rastafarians, Tanzania and Pan-Africanism in the Age of Decolonization. Chapel Hill: The University of North Carolina Press.

Bonacci, Giulia. 2015. Exodus! Heirs and Pioneers, Rastafari Return to Ethiopia. Kingston: The University of the West Indies Press.

Campbell, Horace. 1987. Rasta as Resistance: From Marcus Garvey to Walter Rodney. Trenton: Africa World Press.

Campbell, Horace. 1988. Rastafari as Pan-Africanism in the Caribbean. African Journal of Political Economy 2: 75-88.

Chevannes, Barry. 1994. Rastafari Roots and Ideology. Syracuse, New York: Syracuse University Press.

Diakité, Dianne M. Stewart, and Tracey E. Hucks. 2013. Africana Religious Studies: Toward a Transdisciplinary Agenda in an Emerging Field. Journal of Africana Religions 1: 28-77. [CrossRef]

Dovlo, Elom. 2002. Rastafari, African Hebrews \& Black Muslims: Return 'Home' Movements in Ghana. In Exchange 31. No. 1. The Netherlands: Brill.

Edmonds, Ennis. 2012. Rastafari: A Very Short Introduction. Oxford, England: Oxford University Press.

Middleton, Darren J. N. 2006. As It Is In Zion: Seeking The Rastafari in Ghana, West Africa. London: Equinox Publishing Ltd.

Homiak, John. 2013. When Goldilocks Met the Dreadlocks: Reflections on the Contributions of Carole D. Yawney to Rastafari Studies. In Let Us Start With Africa: Foundations of Rastafari Scholarship. Edited by Jahlani Niaah and Erin MacLeod. Jamaica: The University of the West Indies Press, Institute of Caribbean Studies, pp. 56-116.

Nkrumah, Kwame. 1965. Neocolonialism: The Last Stage of Imperialism. London: Thomas Nelsons \& Sons. 
Olupona, Jacob. 2013. African Religions: A Very Short Introduction. Oxford, England: Oxford University Press.

Owens, Joseph. 1976. Dread: The Rastafarians. London: Heinemann.

Oyěwùmí, Oyèrónké. 1997. The Invention of Women: Making An African Sense of Western Gender Discourses. Minneapolis: University of Minnesota Press.

Pierre, Jemima. 2013. The Predicament of Blackness: Postcolonial Ghana and the Politics of Race. Chicago: The University of Chicago Press.

Price, Charles. 2009. Becoming Rasta: Origins of Rastafari Identity in Jamaica. New York and London: New York University Press.

Salter, Richard. 2008. Rastafari in a Global Context: Affinities of 'Orthognosy' and 'Oneness' in the Expanding World. In IDEAZ: The Globalization of Rastafari. Edited by Ian Boxill. Kingston: Arawak Publications, vol. 7, pp. 10-27.

Savishinsky, Neil J. 1994a. Baye Faal of Senegambia: Muslim Rastas in the Promised Land? Africa: Journal of the International African Institute 64: 211-19. [CrossRef]

Savishinsky, Neil J. 1994b. Rastafari in the Promised Land: The Spread of a Jamaican Movement among the Youth of West Africa. African Studies Review 37: 19-50. [CrossRef]

Savishinsky, Neil J. 1998. African Dimensions of the Jamaican Rastafarian Movement. In Chanting Down Babylon: The Rastafari Reader. Philadelphia: Temple University Press.

Warner-Lewis, Maureen. 1993. African Continuities in the Rastafari Belief System. Caribbean Quarterly 39: 108-23. [CrossRef]

White, Carmen M. 2007. Living in Zion: Rastafarian Repatriates in Ghana, West Africa. Journal of Black Studies 37: 677-709. [CrossRef]

White, Carmen M. 2010. Rastafarian Repatriates and the Negotiation of Place in Ghana. University of Pittsburgh of the Commonwealth System of Higher Education. Ethnology 49: 303-20.

(C) 2020 by the author. Licensee MDPI, Basel, Switzerland. This article is an open access article distributed under the terms and conditions of the Creative Commons Attribution (CC BY) license (http://creativecommons.org/licenses/by/4.0/). 
Article

\title{
Conversion to Orthodox Christianity in Uganda: A Hundred Years of Spiritual Encounter with Modernity, 1919-2019
}

\author{
Dmitri M. Bondarenko ${ }^{1,2, *}$ and Andrey V. Tutorskiy ${ }^{3}$ \\ 1 Institute for African Studies, Russian Academy of Sciences, 123001 Moscow, Russia \\ 2 International Center of Anthropology, School of History, Faculty of Humanities, National Research \\ University Higher School of Economics, 105066 Moscow, Russia \\ 3 Department of Ethnology, Faculty of History, Lomonosov Moscow State University, 119991 Moscow, Russia; \\ tutorski@hist.msu.ru \\ * Correspondence: dbondarenko@hse.ru
}

Received: 26 March 2020; Accepted: 29 April 2020; Published: 1 May 2020

\begin{abstract}
In 1919, three Ugandan Anglicans converted to Orthodox Christianity, as they became sure that this was Christianity's original and only true form. In 1946, Ugandan Orthodox Christians aligned with the Eastern Orthodox Church of Alexandria. Since the 1990s, new trends in conversion to Orthodox Christianity in Uganda can be observed: one is some growth in the number of new converts to the canonical Orthodox Church, while another is the appearance of new Orthodox Churches, including parishes of the Russian Orthodox Church Outside of Russia and the Russian Orthodox Old-Rite Church. The questions we raise in this article are: Why did some Ugandans switch from other religions to Orthodox Christianity in the first half of the 20th century and in more recent years? Were there common reasons for these two developments? We argue that both processes should be understood as attempts by some Ugandans to find their own way in the modern world. Trying to escape spiritually from the impact of colonialism, post-coloniality, and globalization, they viewed Catholicism, Anglicanism, and Islam as part of the legacy they rejected. These people did not turn to African traditional beliefs either. They already firmly saw their own tradition as Christian, but were (and are) seeking its "true", "original" form. We emphasize that by rejecting post-colonial globalist modernity and embracing Orthodox Christianity as the basis of their own "alternative" modernity, these Ugandans themselves turn out to be modern products, and this speaks volumes about the nature of conversion in contemporary Africa. The article is based on field evidence collected in 2017-2019 as well as on print sources.
\end{abstract}

Keywords: Orthodox Christianity; conversion; ritualism; religiosity; Uganda; modernity; post-coloniality; globalism; anti-globalism

\section{Introduction}

This article focuses on encounters between Ugandan Orthodox Christian communities and processes of globalization and modernization in the 20th-21st centuries. We perceive these processes through the lens of conversion to different Orthodox Christian denominations. At first glance, it seems that the very act of becoming a Christian is a sign of globalization on the African continent and that Christianity itself is a part of the global culture. However, for Ugandans several consequential conversions from one Christian denomination to another are acts of the free will that put them on their own path in the global world. They perceive different Christian denominations as either more Western or more African. Thus, the act of choosing the "right" denomination means finding a more appropriate way for Africans to assert their cultural independence. For Africans, conversion to a specific Christian 
denomination may paradoxically mean returning to their roots and rejecting global culture. By trying to escape the modernity associated with colonialism, post-coloniality and globalization, Africans are seeking to construct their own "alternative" modernity.

The field evidence for this article was collected in 2017-2019 by the present authors and their associates among Orthodox Christians of two Churches- the Eastern Orthodox Church of Alexandria and the Russian Orthodox Old-Rite Church. The work was done in different parts of the country: in the capital city of Kampala, in towns and villages in the central, eastern, and western parts of the country, predominantly populated by different ethnic groups—the Ganda, Soga, Nyankole, and others. The fieldwork was conducted partly in English and partly in Luganda with the help of translators, all Orthodox Christians themselves. The methods used were questionnaires, interviews (structured, semi-structured, and non-structured), and intensive observation (participant when possible). Among Christians of the Eastern Orthodox Church of Alexandria, 40 questionnaires were filled out by, and 19 interviews done with men and women of different age groups in three parishes in the vicinities of the town of Fort Portal in the west of the state. As for adherents of the Russian Orthodox Old-Rite Church, 125 questionnaires were received in all the four settlements in which they are present. This means that the questionnaires were filled out by about five-sixths of Ugandan Old Believers' total number. A total of 60 interviews with men and women aged 19 to 90 years were recorded. More than 1500 original photos and about 20 video records documented the variety of events in the religious life of Ugandan Orthodox Christians (services, the rite of baptism, classes in Sunday school, a wedding ceremony, etc.), as well as in their daily life at homes and working places. Fieldwork was complemented by examining Ugandan museum collections, memorials, and "memory spaces" related to religious history of the country, studying written sources on it, visiting many non-Orthodox religious communities and their places of worship, as well as social institutions like schools and universities in different parts of Uganda, in order to better understand the country's landscape-religious and socio-cultural in general. We believe that the evidence at our disposal allows us to effectively approach the research problems we raise in this article.

\section{The Facets of Modernity}

It is necessary to clarify some aspects of "modernity", a term which is central to this article. The term emerged in the middle of the 19th century, when Karl Marx and Auguste Compte were elaborating their understanding of changes in culture and society, especially the decline of feudal society and the awakening of revolutionary tendencies (Larrain 2000, p. 13). Max Weber offered a sociological treatment of modernity in The Protestant Ethic and the Spirit of Capitalism. Weber designated rationality and a special "modern economic order" as the main traits of modernity, which he contrasted to the "old order" and tradition (Weber 1953, p. 181). Since then, modernity has generally been associated with "Western societies" as opposed to "non-Western societies". Furthermore, the notions of modernity and modernization have become crucial for understanding changes in the 20th century, especially in colonial and post-colonial countries.

A reexamination of the notion of modernity began at the turn of the 20th century (see, e.g., Appadurai 1996; Gaonkar 2001; Wagner 2001, 2008; Therborn 2003). For the purposes of this article, we found its reinterpretation by the sociologist Shmuel Eisenstadt most appropriate. Importantly for the discussion that follows, Eisenstadt noted that modernity was not a set of once and forever fixed patterns of structural changes. Even Weber and Marx implicitly spoke about different ways of accessing the "new order". Eisenstadt granted the status of modernity not only to European (Western) Modernity, which he called "original", but also to "later modernities"—Eastern European, Japanese, Chinese, and others (Eisenstadt 2000, 2002, 2003; see also Ben-Rafael and Sternberg 2005; Preyer and Sussmann 2015). Advocating for "multiple modernities", Shmuel Eisenstadt rightly pointed out that "the best way to understand the contemporary world-indeed to explain the history of modernity-is to see it as a story of continual constitution and reconstitution of a multiplicity of cultural programs" (Eisenstadt 2000, p. 2). We fully agree with this argument and believe as firmly as Eisenstadt did that 
"modernity and Westernization are not identical" (Eisenstadt 2000, p. 2). Yet, we also agree with him that "Western patterns of modernity ... enjoy historical precedence and continue to be a basic reference point for others" (Eisenstadt 2000, pp. 2-3). The introduction of this view led to a reevaluation of relations between the Western and (post)colonial cultures.

In particular, it inspired Joel Robbins $(1998,2001)$ to introduce the concept of "Melanesian Christianity" as a manifestation of "local modernity". Departing from the notion of "cargo-cult", he argued that Melanesian Christianity was something more than that. It was not a false or distorted expression of European religion, but rather a Melanesian form deeply rooted in the Melanesian peoples' pre-Christian beliefs. For Robbins, to be modern means to be able to create new assumptions about human beings, their rights and agency, and in this sense "local moderns" are not "alternative" or "vernacular" moderns, but literally "local moderns", equal to "Western" moderns.

The idea that everyone can be modern in their own way has begun to spread in academic texts. In 2006, Volker Schmidt published an article in which he came to the same conclusions as Robbins. He criticized Eisenstadt's ideas for being empirically dubious. Schmidt wrote that within the concept of "multiple modernities" Eisenstadt actually considered the societies he ascribed the status of "modern" as higher than those that were not offspring of the Axial Age civilizations. However, all societies in the contemporary world tend to be modern in this or that way and thus it would be better to talk about different "varieties-of-modernity" (Schmidt 2006, p. 88).

An important recent contribution to the discussion of modernity and its regional dimensions has been made by Nikolai Ssorin-Chaikov (2016). Analyzing the practices of building modernity in the small Siberian town of Katonga, Ssorin-Chaikov argues that modernity is comprised of many parts or "projects" that sometimes destroy some of the previous projects. From this perspective, there is no homogeneous "Russian modernity". In every region, modernity is a specific set of projects, such as buildings, infrastructure, values, and senses. All these components are aimed at forming a more rational way of living, based on human rights and individualism, which may always remain unfinished.

In African studies, on the one hand, there are recent publications in which African realities are approached as a clash of "the tradition" and "the modernity" —authentically African and Western, respectively (e.g., Mami 2011; Caldeira 2016; Bitrus 2017). However, the look at colonial and postcolonial Africa as a specifically modern part of the world rather than an arena of "struggle" between the tradition and the only possible Western modernity has quite a long history by now, too. Probably, the Comaroffs were the first Africanists to declare: "There are, in short, many modernities" (Comaroff and Comaroff 1993, p. xi). This line of reasoning was continued in their own and others' publications, including those in which colonial and post-colonial Africa (in general or at the level of individual states) is discussed directly in the context of the "multiple modernities" conception (e.g., Comaroff and Comaroff 1997; Ferguson 1999; Deutsch et al. 2002; Nkwi 2015; Wagner 2015; Palmer 2018a, 2018b; Imafidon 2020). Importantly for our discussion in this article, the multiple modernities conception is very well compatible with the theories that consider colonial and post-colonial societies as specific socio-cultural forms whose uniqueness is predetermined historically, by the unprecedented way of their appearance (e.g., Wallerstein 1966; Balandier 1970; Mbembe 2005; Bhambra 2007; Osterhammel 2010; Mamdani 2018).

According to Robbins, Ssorin-Chaikov, and the Comaroffs, among other abovementioned authors, "modernity" in Melanesia, Siberia, or Africa is not about being modern in the "Western sense" but about the creation of new elements of everyday life and ways of its organizing based on individualism, self-sufficiency, human rights. We showcase that in Uganda, conversion to Orthodox Christianity is a spiritual pathway to a socially acceptable and psychologically comfortable position in contemporary African socio-cultural milieu and the wider globalized world. So, we believe that the frame of modernity allows to understand the phenomenon of conversion to Orthodox Christianity in present-day Uganda.

A significant contribution to the study of encounters with modernity in Uganda was made by Mikael Karlström (2004). He approached the Ganda (the most numerous ethnic group in Uganda that inhabits the Kingdom of Buganda-the core of the British protectorate and then independent republic 
of Uganda) as a kind of "moral community" reproducing itself in the situation of African modernity, characterized by a moral crisis that has been lasting since colonial times. Karlström showed that the Ganda sustain an aspirational engagement with their changing world against considerable odds by recourse to kingship and rituals of social reproduction. He emphasized that the Ganda's sense of "a collective future" was modern yet distinctly Ganda, as it was rooted in their belief in indestructible power of the Kabaka (the King of Buganda) and inextricable mystical connection between him and his people (see also Karlström 1999). Our own fieldwork gives all grounds to argue that these trends have become even stronger since the time of their study by Karlström. In many Ganda Orthodox with whom we communicated, the belief in God coexisted with what can be called "Ganda nationalism" (or "Ganda ethnic patriotism", as Derek Peterson (2012) would prefer to call it) and even with the idea of Ganda exceptionalism manifested, particularly in veneration of the Kabaka and based on the assumption of the Buganda Kingdom's political and cultural domination in the region in the past.

However, Ugandan Orthodox communities are not limited to the Ganda to no lesser degree than Uganda herself (Bondarenko 2019, p. 133), while Ugandans' encounters with modernity are far from being inspired exclusively by "ethnic patriotism". Religion is another powerful inspiration for them, with its own attractors, and their religious communities as specific parishes, "moral communities" (Babst 2011) or "invented communities" (Anderson 2006), are multi-ethnic. The intricate interplay of the ethnic, religious, and political is what was studied so deeply by Peterson by the evidence on late colonial and early post-colonial Uganda (Peterson 2012, pp. 50-104, 249-80). Our aim in this article is different. We do not intend to describe what being modern might mean in Uganda objectively, in reality, or rather, in fact, from our, academics and outsiders', point of view. Instead, we are going to look at how Ugandan Orthodox communities are trying to cope spiritually with contemporary socio-cultural reality. We treat these attempts as a specific modernity project, or cultural program, as Eisenstadt would have said. These people may not talk about modernity in the categories scholars do, but they understand very clearly that what motivates them for spiritual community building is the desire to find a place in the modern world, or rather to create their own "small world" within it. Orthodox Ugandans are trying to construct their own traditionalist modernity-strictly Christian but not post-colonial and globalistic. We suggest that, for Ugandans, being Orthodox means not only being "like Europeans" but also keeping their own traditions, and even improving them in some senses. The act of conversion in this sequence of encounters with modernity constitutes the application of Ugandan agency and thus the re-actualization of themselves as "modern".

\section{A Brief History of the Orthodox Communities in Uganda}

The history of Orthodox Church in Uganda begins in 1919 when Islam, Anglicanism, and Catholicism had already firmly established themselves in the country. According to a contemporary account, that year three Anglican priests-Obadiah Basajjakitalo, Rebuen Mukasa Sebbanja, and Arthur Gatuna-bothered by conflicts and rivalry between Catholics and Anglicans, tried to find out the "truth and reality". In the English lexicon they found the word "Orthodoxy" and formed the "Anoonya group" ("Eureka group"—D.B., A.T.). This group started to write letters to different Orthodox institutions. At first "the Greeks [Greek priests from Alexandria Patriarchy-D.B., A.T.] doubted if the native Ugandans would be able to preserve and conserve the Orthodox Faith according to renowned strict tradition and ethos of the Eastern Orthodox Church" (Kato 2014, p. i). The "Patriarch" of the American Orthodox Church, George Alexander McGuire, provided the priests with basic information about the Orthodox tradition. The American Orthodox Church was an offspring of the Pan-African movement. McGuire was an advocate of the idea of a single Black Church. He was ordained a bishop by Rene Joseph Vilatte, whose episcopal orders were declared null and void soon after that (Hayes 1996).

Importantly for the discussion presented below, from the very beginning, Orthodox Christianity was perceived by its adepts in not only purely spiritual but also socio-political context: like many other African Christian ideologists of the late 19th-mid-20th century, the founding fathers of Orthodox Christianity in Uganda 
were attracted to Christianity but felt that the colonial authorities, in cooperation with missionaries, were using religion as a means to control "native" populations. Breaking away from these restraints, these African Christians sought a form of Christianity that was true to what the Bible revealed about the early church but which was free from colonial manipulation. (Lee and Seifemichael 2017, p. 273)

This means that, despite the non-African origin of Christianity, they deeply felt it as their religion, their, Africans', spiritual tradition but at the same time, did not want to belong to its part associated with colonial exploitation. As it will become clear from the subsequent analysis of the evidence in this article, this tension between intrinsic relation of Christianity in Africa to the European cultural and political strengthening on the continent on one hand, and perception of Christianity as their, Africans', religion on the other, remains a fundamental moving force of conversion to Orthodox Christianity in Uganda up to now.

In the early 1930s, Daniel Alexander, a priest of African Orthodox Church from South Africa, came to East Africa. He put a lot of effort into organizing churches in both Kenya and Uganda. In 1932, he ordained Reuben Mukasa as Father Spartas. Since then, the church has officially been named "Orthodox". However, that was just the first act of conversion. It is important to stress that in the beginning the African Orthodox Church in Uganda bore no relationship to mainstream Orthodoxy, apart from sharing the same name.

"Suspicious of these initial schismatic associations, the Patriarchate of Alexandria did not accept the Ugandan and Kenyan churches as fully Orthodox until after World War II" (Lee and Seifemichael 2017, p. 275). Nevertheless, in 1946, the second act of conversion took place, but the chain of events that led to it began in 1933 following the visit of Daniel Alexander. According to an account, that year a Greek came to the Orthodox people of Uganda to baptize a child and told Father Spartas that the ritual they had performed was not Orthodox. After that, the Ugandan Orthodox priests eventually began to turn to the genuine Orthodox Church.

In 1933, the Anoonya group also approached archimandrite Nicodemus Sarikas, who was traveling through Africa to serve the spiritual needs of Greeks. They gave archimandrite Sarikas a letter for the Greek Orthodox Patriarchate in Alexandria. Patriarch Nikolas V proved to be very cautious. It was not until 1939, however, that his successor Christopheros II called for two Ugandan youths, Ermolaos Seddimbu and Irineos Magimbi, who were in Arusha, Tanganyika, to go to Alexandria to learn Greek and Orthodoxy (Kato 2014, p. ii).

In 1945, four young men from Kampala were sent to Egypt to learn the Greek language and the foundations of Orthodox belief. Their names were Theodoros Nankyama, Dimitrios Mumbale, George Lubulwa, and Elias Katumba. After studying in Greek high schools in Egypt, they studied theology at the University of Athens. In 1946, "Rev. Father Reuben Spartas was invited by the Greek Patriarchate of Alexandria to visit Egypt. The African Orthodox Church was officially recognized by the Patriarchate of Alexandria under the name 'African Greek Orthodox Church'"' (Kato 2014, p. ii).

Since that time, the Ugandan Orthodox Church has been a part of Alexandria Patriarchate-the Eastern Orthodox Church of Alexandria. This church was not linked to colonial powers and has never been associated with racism, colonialism, or religious imperialism. However, the Alexandria Patriarchate focused first of all on the needs of the Greek Orthodox community. That is why the center of the new African Metropolis was fixed in Dar es Salaam (Irrinoupolis in Greek) in Tanganyika, where more Greeks lived. However, in 1995, the Holy Metropolis of Irinoupolis was divided into three metropoles, of Irinoupolis, All Kenya, and Kampala and All Uganda.

Since 1997, the Metropolitan of Kampala and All Uganda is Jonah (Lwanga), a grandson of Obadiah Basajjakitalo, one of the three first Ugandan Orthodox Christians. His residence is in Namungoona, a suburb of Kampala, the headquarters and spiritual center of Ugandan Orthodox Christians, as their Cathedral is situated there, too. According to the National Census 2014, Orthodox Christians count for 48,421 persons or $0.1 \%$ of the country's population; $3 / 4$ of them reside in rural areas and $1 / 4$ are city-dwellers (Uganda Bureau of Statistics 2016, pp. 19,73). The website of Uganda Orthodox 
Church (2019) reports that "[t]he clergy consists of a team of 76 priests and 5 deacons. There are over 100 communities, 41 brick and mortars churches, 17 medical clinics and one Holy Cross Orthodox Hospital."

It is worth noting that the Eastern Orthodox Church of Alexandria was on good terms with the Ugandan state throughout its whole history. In particular, when in 1977 the dictator Idi Amin banned 27 religious organizations, the Orthodox Church was granted freedom of worship alongside only Muslims, the Anglican, and Roman Catholic Churches (Anonymous 1977; Kivengere 1977, p. 28). Today, Uganda Orthodox Church (the Eastern Orthodox Church of Alexandria) is a member of the state-established Inter-Religious Council of Uganda. Membership in this body gives a religious organization a kind of state protection, serves as a sign of its recognition by the state. It is not by chance that since 2016, when the government announced its intention to enact a policy about regulating religions and faith-based organizations, the Inter-Religious Council member religious organizations, including the Eastern Orthodox Church of Alexandria, have supported the state's proposal, while non-member religious organizations have not (Alava and Ssentongo 2016; Isiko 2019). Among many photos on the walls of the office of the Metropolitan of Kampala and All Uganda Jonah, the photo of the President Yoweri Kaguta Museveni occupies an especially prominent place (while the Metropolitan considers himself a devoted subject of the Kabaka of Buganda Ronald Edward Frederick Kimera Muwenda Mutebi II, too).

Also, the canonic Russian Orthodox Church Outside of Russia (ROCOR, or Russian Orthdox Church Abroad-ROCA) in Uganda has the only parish of about one hundred parishioners of the Annunciation Church. It was founded in 1983 on the remote Bukasa Island on Lake Victoria. The parish is under the spiritual Omophore of Metropolitan Hilarion of ROCOR. Since 2007, ROCOR has been semi-autonomous from Russian Patriarchy, though before that it was completely isolated from Moscow. This geographically enclosed parish earns a living selling chickens, charcoal, and oranges on the mainland. Metropolitan Vitaly ordained the priest, Father Christopher Walusimbi, in 1988 in Montreal, Canada. Father Christopher is the first African priest of ROCOR and the only one in Uganda. Despite the remoteness of the ROCOR parish, he is known to and respected by adherents of the Eastern Orthodox Church of Alexandria, and several of them recalled him in our talks.

In the 1990s, communities of Orthodox Old Believers appeared in Uganda. Old Believers is a name for Orthodox Christians whose ancestors resisted the reforms of Patriarch Nikon of Moscow, implemented in 1652-1666, which introduced contemporary forms of Greek Orthodox worship to Russia. Today, there are about 150-200 Old Believers in Uganda, who reside in Kampala, mainly in the neighborhood of Mpererwe, and in the villages of Nakabaale, Kisojjo, and Kapeke. Except the youngest members of the communities, all these people have converted to Old Believers from Catholicism, Protestantism (mainly Anglicanism), Greek Orthodox Christianity, or Islam in conscious age (Bondarenko 2019, pp. 137-38).

In 1991, the priest of the Eastern Orthodox Church of Alexandria Father Joachim Kiyimba separated from the canonical Church and joined the Greek Old-Rite Holy Synod in Resistance. He had known about Old Believers since the 1970s when he studied at the Leningrad Theological Seminary in the USSR. Father Joachim, a charismatic person endowed with the gift of persuasion and known for his vigorous preaching, gathered a circle of followers. Already in 1991, he founded the communities in Mpererwe, in which he resided and in Nakabaale, in which he grew up. But in 1998, his parish in the name of SS. Joachim and Anna joined the Uniate Syriac-Greek Antiochian Orthodox Catholic Church. The following year, however, Father Joachim came in touch with the Holy Orthodox Church of North America (Boston Synod). The Boston Synod accepted him into prayerful communion in 2000, and he became a cleric of the Orthodox Church in Africa/Uganda. This relationship did not last long. In 2004, Father Joachim returned to the Holy Synod in Resistance, where remained until 2007, when he joined the True Orthodox Church of America.

In 2012, Father Joachim sent a letter to Metropolitan of Moscow and All Rus, Primate of the Russian Orthodox Old-Rite Church Korniliy in which he wrote about his desire to join this Church. His application was accepted by the Metropolitan Council, which invited Father Joachim to Moscow 
and ordained him as a priest of the Russian Orthodox Old-Rite Church on 22 May 2013. After coming back to Uganda, he tried his best to expand the size of the flock and organize community life according to the traditions of the Old Believers. However, on 9 January 2015 he died of an incurable disease.

The Metropolitan Council selected the new priest, Father Joachim Walusimbi, from two candidates and ordained him in Moscow on 20 September 2015. Born to a Catholic family, Walusimbi changed affiliation for Orthodoxy in 1998 and became a priest of the Eastern Orthodox Church of Alexandria. In 2012, influenced by Father Joachim Kiyimba, he left this church and joined Old Believers. Under Father Joachim Walusimbi, some residents of his native village of Kepeke became Old Believers. Moscow Metropolis continues to support the fellow believers in Uganda, though its financial contribution remains very limited.

A farmer named Alex Chakka, who passed away in 2018, founded the community in Kisojjo in 1999. Alex was not in touch with Father Joachim Kiyimba at that time and was inspired to become an Old Believer by his uncle, who had already been converted by Father Joachim Kiyimba. Since 2013, the Russian Orthodox Old-Rite Church has patronized the community in Kisojjo (Anonymous 2015, 2017; Urushev 2016, pp. 334-36; Bobkov 2017, pp. 28-34; Bondarenko 2019, pp. 131-33).

Father Joachim Walusimbi is the only Old-Believer priest in Uganda. The church of SS. Joachim and Anna, built on funds of the Russian Orthodox Old-Rite Church, is the only functioning Old-Believer church in the country. The church in the name of St. Mary of Egypt in Nakabaale remains unfinished due to a lack of funds. The financial position of all the communities is poor and the ties between are weak (Bondarenko 2019, p. 134).

\section{Conversion to Orthodox Christianity in the Socio-Cultural Landscape of Post-Colonial Modernity}

Before proceeding to the topic of conversion in Uganda and discussing the particular features of this phenomenon, we want to discuss the broader context of cultural events, economic links, and Ugandan everyday life where all of these processes of religious change are taking place. These are typical features, or aspects of the socio-cultural landscape of Ugandan post-colonial modernity.

It is important to stress that most Ugandan villages and towns are multiethnic, multicultural, and multi-denominational. Greek Orthodox Christians as well as Old Believers constitute minorities in religiously diversified settlements. It is impossible for them to separate themselves from co-villagers of other religions. For example, the dwellers of the village of Ngombe are Orthodox Christians, Catholics, Anglicans, and Muslims. Although the Orthodox Church is the largest Christian community and the Chair of the Village Council is its parishioner, Orthodox residents do not constitute the majority of the population. The village of Nakabaale and its vicinities is home to Anglican, Greek Orthodox, Old-rite Orthodox (Old Believers), and Catholic churches, as well as a mosque. Most inhabitants in Kisojjo are Catholics, Anglicans, or Pentecostals.

All Orthodox Christians and Old Believers have relatives who do not belong to their religious group, and most of their friends and business partners are also not Orthodox Christians or Old Believers. The believers of both denominations have nothing against other believers visiting and even participating in their services. In Ngombe, the yard-keeper of the church is an old Muslim woman who is raising two little boys who have been baptized in Orthodox tradition. She cleans the plot around the church and from time to time (about once in three months) comes to the service. Not a single parishioner has anything against her. In Kisojjo, we saw several Catholics attending the service and praying together with Old Believers. In Mpererwe, the widow of Father Joachim Kiyimba, who was a vice principal at a school, invited her students of all Christian denominations to give a concert of religious hymns after the Old-Believer Divine liturgy which they attended. The story of a woman from Ngombe is instructive in this respect. In the years 2014-2016, the roof of her house burned five or six times. She was frightened and asked an Orthodox priest to pray for her and to pray near her house, but these prayers did not help. She then asked a Catholic priest to do the same, and, finally, an Anglican pastor. After the last prayer the fires stopped. Every Sunday, this woman now goes to an 
Anglican church five kilometers from Ngombe, but she comes to the Orthodox church every year for the Easter service.

The second important feature of the religious landscape in Uganda is interdenominational marriages. Here, one can observe an interesting difference between Old Believers and Canonic Orthodox Believers. The former are more tolerant of their relatives belonging to other Christian traditions and do not actively try to make them join the Old Believers. However, the Old Believers do try to keep away from Muslims. The Canonic Orthodox Believers have close relationships with Muslims, but they try persistently to convert their non-Orthodox (not only Muslim) relatives to their faith.

Most Ugandan Old Believers were baptized into the faith after they were married, and not all of them have been able to persuade their spouses to follow them. Intermarriages with non-Old Believers are very frequent. Many Old-Believer parents admit that their children may marry someone from another Christian denomination (but not a Muslim). Young single Old Believers also see such a prospect for themselves. This observation contradicts the Old-Believer tradition that an Old Believer can only marry another Old Believer. We only encountered one Old Believer during fieldwork who insisted that his bride convert from her faith (Anglicanism) to his. The children of Old Believers are also free to choose to join another denomination. Since Alex Chakka baptized his six children as Old Believers at birth, three converted to Catholicism and Pentecostalism when they grew up.

Greek Orthodox believers insist on the parishioners' spouses coming to the Orthodox Church. One of our Orthodox interlocutors, for example, had a Muslim wife. An Orthodox-Muslim marriage was not regarded as bad or even strange, but from time to time the priest nevertheless told our interlocutor that it was necessary to encourage his wife to join the Church. The Orthodox priest of the Ngombe church converted his Anglican wife to Orthodoxy after the birth of their first child. This difference is reflected in our statistical evidence. Only $16 \%$ of Old Believers we questioned indicated that their family members had influenced their decision to convert, while $65 \%$ of Canonic Orthodox Christians we questioned in Ngombe said that their family members played a role in their decision to join the church. Most of these people converted as children or adolescents while under the influence of their parents, but some were also influenced by spouses, siblings, nephews, uncles, or aunts.

These two aspects of the Ugandan religious landscape show that people of all denominations live together closely, and religious identities do not raise barriers that divide people, but rather create diversity that helps people see life from different points of view. Our friend Nicolas put it this way: "The Church of Uganda have more churches and schools, Catholics have a lot of money, Muslims always help each other, but Orthodoxy is the best because this is our belief." It is important to stress that each religion has its specific economic and social traits from Ugandans' point of view. For a Ugandan choosing a religion is not just about dogma, it is also about everyday life.

Everyday life has an economic dimension which is also related to the church. The third important point is that being a parishioner of a church enables the parishioner to increase their income. People often talk openly about it. As an Old Believer confessed, "This Church [the Russian Orthodox Old-Rite Church—D.B., A.T.] made me happy, but I expected more help and more access to free doctors." Old Believers frequently seek out opportunities to launch businesses that could financially support the Church. By now, their most successful project is a small poultry farm in the village of Kapeke. However, support from Russian and occasionally Australian and American coreligionists in money and in kind (icons, liturgical utensils, as well as, for example, clothes and toys for kids) remains the main source of both income for the Ugandan Old-Believer Church and also hope for the future for its members.

The economic life of the Greek Orthodox Church in Ngombe is more vibrant and includes a lot of economic activities. Importantly, it includes land ownership. The traditional king of Tooro, on whose territory Ngombe is situated, donated huge plots of land on the tops of several hills to the Orthodox Church. The activities of the Orthodox Church rely on the rents the church collects from these plots. For example, the church gave one of the plots to a Catholic school, and the school administration both pays the rent to the Orthodox Church and gives the Orthodox students a tuition discount at the 
Catholic school. A small medical center occupies another plot of land. The doctor is Orthodox and she offers her co-parishioners a $10 \%$ discount for her services.

The village women council, which is run by an Orthodox woman, also uses the public space of this medical center. The women council provides opportunities for women to produce and sell their handicrafts to a German businessman living in the nearby city of Fort Portal. All the women in Ngombe can become members of the council, but the Orthodox Christian members pay smaller fees. Economic activities are not the main activities of the church. They are nevertheless very important for the parishioners, who view them as a central part of what constitutes "good" or "true" belief.

The fourth aspect is a steady connection between religious acts and everyday life. Our interlocutors told us that "God will grant wealth and good health to those who have enough faith" almost unanimously ( $96.6 \%$ of Old Believers and $94.9 \%$ of Greek Orthodox Christians). Mundane reasons for being a believer do not seem to be the only or even most important ones. Rather, the informants preferred moralistic and "social" explanations of religion's importance. One informant stated that "Religion helped me to understand what is good and what is not. It has changed my life-I do not have bad habits, I live a humble life." Another indicated that "Religion has done something tremendous in my life-it gave me good friends and allows to live a happy life." Another informant also told us: "If I don't fast who will protect me?"

The attitude of adherents to fasting is important for the present discussion. One of our interlocutors, a fifty-year-old Greek Orthodox woman told us: "If I have little money, I start sleeping on the floor." The priest of Ngombe church, Father Romanos, told us a very similar story: "If I have a lot of problems and I can't solve them, I fast. I like milk very much, so I desist drinking it. I also like bananas. If milk doesn't help, I stop eating bananas." The approaches to fasting represented in these stories are different: in the first one the woman makes herself enjoy inconvenience, and in the second a person refuses his favorite meals. The former is closer to Russian Orthodox practices and the latter is closer to Western European practices. It is difficult to explain this difference because Father Romanos was trained at a Russian seminary. Despite the difference in their approaches to fasting, the main point of the two stories is the same: people attempt to solve everyday problems through religious means. Thus, the economic life of a certain parish or denomination is not just about ownership, investments and rents, it is also about faith, fasting, and performing "true" and "original" rituals.

The last aspect of the landscape of conversion in Uganda we want to single out is the co-existence of monotheistic and non-monotheistic African religions. Our interlocutors from the Old-Rite Russian Orthodox Church were extremely critical of those people who showed tolerance towards non-monotheistic African religions. Of those who filled out our questionnaire, 7.4\% stated their aversion to Catholics and Protestants, 9\% to non-Old-Believer Orthodox Christians, 24.2\% to Muslims, and $78.9 \%$ to the believers of non-monotheistic African religions. Many respondents noted that there were people in their settlements who performed "pagan rites". What made our old-believers respondents especially wary of the "pagans" is that all of them were what they called "double believers" - people of multiple religious belonging who perform rites of non-Christian religions but also go to church. In the words of the Catholic Chairperson of the Village Council in Kisojjo, "They try to derail people from God, they make confusion. They do it indirectly, because most often they want to make money, so they persuade Christians not to go to church. When a Christian falls ill, they call him or her to treat by sorcery methods for money, cattle or poultry." For our common Greek Orthodox interlocutors, this problem did not seem serious at all. An old woman told us: "We don't have pagans here. But if they had been here, we would definitely live in peace with them." However, the Metropolitan of Kampala and All Uganda under the Eastern Orthodox Church of Alexandria Jonah told us passionately that "double believers" are a serious problem for Ugandan society at large from his, a Christian hierarch's, point of view. 


\section{Conversion to Orthodox Christianity as Spiritual Encounter with Modernity}

Conversion is an act that can manifest the agency of contemporary individuals. To demonstrate their agency, a Ugandan can apply for a job, launch a business, or pursue education, but all of these actions presuppose the hierarchical relations of the post-colonial globalized world. All of the long chains of relationships in companies, universities, or enterprises lead to the West, to China, or to elsewhere outside of Africa. Thus, to effectively express their agency and activity in these domains, Ugandans must depart from their "Africanness" and embrace their "globalness", which, in the minds of Africans, is usually rooted in the slave trade and colonialism, and, more recently, associated with neocolonialism (e.g., Olurode 2003; Msellemu 2004; Ogundowole 2004, pp. 186-210; Offiong 2013; Kanu et al. 2018). On the contrary, for conversion, the approval of peers and the religious community is enough. Conversion presents a rare opportunity for Ugandans to manifest agency without embracing their "globalness". At the same time, becoming a parishioner can also be the first step to the big world. For example, in 2017, a member of the Orthodox Church Council in Ngombe became a member of the national Parliament.

The act of conversion is a manifestation of an individual's agency, while showing respect to traditions and people of your native land at the same time. In fact, conversion has both an individual and a communal dimension. Three ex-Anglican priests began the conversion movement to Orthodox Christianity in 1919, because they were motivated by the idea of finding the one true religion, not only for themselves, but also for their parishioners. The spiritual journey of Father Joachim Kiyimba from 1991 until his death in 2015 was a fascinating odyssey in which all his parishioners partook. In 2018, one of the authors of this article had a meeting with two deacons from St. Sophia Orthodox Church in Kampala who were thinking of joining the Russian Church outside Russia or the Russian Orthodox Old-Rite Church. This was more than a search for personal spirituality or career: those deacons were discussing the possibility of changing the affiliation of the church together and carrying along a part of parishioners with them. More importantly, in the still communalist Ugandan society, even most individual actions unavoidably become known to, discussed, and approved or disapproved by the whole community, be it a village, a town ward, or a parish. Individual behavior, even in most vivid manifestations of personality, is to be approved in society with its unwritten but clear norms, and that is why in such cultures individual agency is always immersed in collective.

Yet, the conversion movement to Orthodox Christianity has important specific features. Although the history of Old Believers in Uganda is brief, all of the members of the Old-Believer community (except children) were not born into the faith but rather converted to it from other religious traditions-Protestantism of different denominations (mainly Anglicanism), Catholicism, Orthodox Christianity of the Patriarchate of Alexandria, and Islam. Some adult Ugandans from other Christian denominations and Islam are also attracted to the Eastern Orthodox Church of Alexandria (Bondarenko 2019, pp. 137-39). Why did these people decide to change their religious affiliation? What did they find so attractive in this or that brand of Orthodox Christianity compared to their previous religious allegiances? Why did they consider the new faith better than their old ones? Some interlocutors said that they hoped for better support from their new church in everyday life. However, for many more the main reason for conversion was spiritual. They said that they had realized that just the Orthodox faith is the "true religion". Those born into the Orthodox faith strongly believe in it, too. But why do they think so? And what does the "true religion" for them consist of?

The explanation for why the Old Believers is the true religion that Father Joachim Kiyimba gave the people while persuading them to accept the new faith, as they eagerly recalled in interviews, was that Old Believers strictly observe wholly and unchanged the most ancient complex of prayer rites. Most people who apply to join the Eastern Orthodox Church of Alexandria, as Metropolitan Jonah told, are also motivated by the desire to find the original and true religion. They apply because, as he said, "they find somewhere in books that the Orthodox Church is the Mother Church." As an elderly Old Believer woman said, "I changed religion because I learned that this religion observes the most original canon of worship." Another respondent indicated that they converted "because previous 
rites were not correct". This logic infers that Orthodox Christians practice the most correct way of praying, of glorifying and addressing God. In fact, this is what attracts people willing to "turn to tradition" to different brands of Eastern Christianity, not only in Africa but also in the West (Slagle 2011; Herbel 2014).

Father Joachim Walusimbi himself changed from Greek Orthodox Christianity to Russian Orthodoxy because, as he said, Father Joachim Kiyimba had explained to him that "Russian Orthodoxy is closer to original Christianity than Greek". On the same grounds, some of our interlocutors preferred the Old-Believer Church to Evangelical Pentecostal Churches: "This is the church where you can find original teaching, original message from God, not like at commercialized Evangelical preachers"; "Pentecostal churches attract people by songs, the way they present themselves but they don't follow the original Christian tradition, so everything [they do] is meaningless". The antiquity and hence presumed invariableness of the ritual were represented as the sign and pledge of the truth of religion. The ritual was valuable for the interviewees in itself, beyond semantics. Even more so, the splendor and colorfulness of the Orthodox ritual (no matter Old or New Rite) had a psychological impact on the prospective converts. Many of them, especially those who were Protestants, were impressed by it and became convinced that Orthodox Christians are "stronger believers".

Most Ugandan Orthodox Christians seem uninformed about, and not concerned about, the dogmatic differences between their "true religion" and other religions (with respect to Old Believers, see: Bondarenko 2019, pp. 139-41). What really matters for them is the ritual. If someone observes the true complex of rites, this person is practicing the true religion. One of the oldest persons in Ngombe, a Catholic, said "there is no difference between Catholics and Greek Orthodox believers except the way they cross themselves. Formers do it with two fingers and latters with three fingers. And that's all." This man was baptized in Catholicism in the early 1930s. His first wife was Catholic and the second is Orthodox. The children from the first marriage were baptised in Catholicism and the children from the second in Orthodoxy. His second wedding took place in an Orthodox church. So, this man is quite sophisticated in the rituals of the two denominations and his opinion is not based on poor information. This vague knowledge of the outlines of Orthodox Christianity manifests itself in the filled-out questionnaires: $33.1 \%$ of Old Believers and $40.6 \%$ of Greek Orthodox thought that blessing with, respectively, two or three fingers means Jesus's second coming, while in reality blessing with two fingers symbolizes Jesus's two natures—divine and human, and blessing with three fingers signifies confession of the Holy Trinity.

The overwhelming majority of our respondents argued that religion played a very important role in their lives. Asked why this is the case, many of them answered that religion was very important because it provided knowledge of and guidance by God. Informants stated: "To be Christian means to believe in Jesus Christ as one God." Without religion they "couldn't be sure about afterlife", as a respondent put it. For them, "to be Christian means to believe in afterlife," and a good afterlife is attainable through practicing the true religion. As an Old Believer explained, "Religion gives us hope for eternal life-life after death, and belief that we are created for a purpose. That is why we should be responsible for the quality of our lives - the way we live as Christians: ask for forgiveness, pray, read the Bible, and follow the commandments." Many respondents used the word "hope" describing what the faith meant for them. So, it is vitally important to practice the true religion, understood as strict observance of the rituals, for having a better life now and the prospects of an afterlife in the future.

Thus, for our respondents, the way of life is dictated by religion. Faith is about hope, moral guidance, relationships, and protection from sin. That is a lot more than the ritual, but at the same time, the ritual is more than a small part of religion. In a sense, the ritual is what religion is all about for them, and even what life is all about, because religion is seen as the ritual first and foremost-the ritual is definitely more essential for these people than a dogmatic doctrine. Louis Brenner (1989) made this argument with regards to African religiosity in general, and our evidence on Ugandan Orthodox Christians confirms it. Presumably the most ancient, original, and unchanged way of performing rituals is the most correct one for them. The most correct way of performing rituals is what 
distinguishes the true religion in their view, and the true religion is the most effective religion-the one which practicing can actually help achieve the best results in this life (e.g., strong health or financial prosperity, or on concrete occasions: an abundant harvest this year, a child's quick recovery from a disease) and make you sure of getting a blissful eternal afterlife in paradise. These Ugandans changed their faith because they became convinced that Orthodox Christians (Old Believers or canonic) most completely and accurately observed the original Christian rite, and thus practice the true faith, which is most effective in the aforementioned sense.

The conversion of some Ugandans to Orthodox Christianity-canonic of the Eastern Orthodox Church of Alexandria and the Russian Orthodox Church Outside of Russia or old-believer of the Russian Orthodox Old-Rite Church - can be instructive for developing a clearer understanding of the important phenomenon of contemporary African religiosity as a way of encountering modernity. Religiosity is understood here not as a belief but rather a type of spirituality, rooted in the feeling of existence and constant presence in the world and human life of the supernatural, that is, a religious feeling regardless of particular religions in which it manifests itself. This feeling shapes people's worldviews and social behaviors. "Religiosity" is used here in opposition to "secularism", and it should be noted at this point that the extent of secularization in Africa is low (e.g., Martin 2009; Lugo and Cooperman 2010, pp. 1, 20). As van den Toren and de Wit have argued: "Africa provides examples that modernity does not automatically lead to secularization" (Van Den Toren and Wit 2015, p. 153), at least in its version known to the West. Rather, as Lugo and Cooperman have observed: "Indeed, sub-Saharan Africa is clearly among the most religious places in the world" (Lugo and Cooperman 2010, p. 3). So, religiosity forms a fundamental aspect of individual and mass consciousness in present-day Africa.

Today, many Ugandans, as well as other Africans, are engaged in religious practices that are not particularly based around ritual. However, the religions typical of the past-the so-called African traditional religions-like religions of that kind elsewhere, were not doctrinal, they did not have theology and a complex of clearly formulated and unquestionable dogmas. They were, rather, based on the conviction in the effectiveness of a ritual act. In the words of the historian of religion Wilfred Smith: "what theology is to the Christian Church, a ritual dance may be to an African tribe" (Smith 1979, p. 15). More than a century ago, one of the most prominent anthropologists of the time, Robert Marett, made the same argument: "savage religion is something not so much thought out as danced out" (Marett 1914, p. XXXI). In his days, the expression "savage religion" or "savage religions" referred to what more or less coincides with, for example, such a contemporary academic term as "archaic religions" as opposed to "religions of the Book". Catherine Bell explains:

The logic of this is not hard to see. In tribal or local societies, which tend to be relatively closed and homogeneous, religion is not something separate from community identity, ethnic customs, political institutions, and social traditions. Beliefs are rarely formulated and spelled out in these circumstances, and they do not need to be. It is the formal and informal customs and obligations-namely, ritual responsibilities like attending to the ancestors, arranging the marriage of one's children, and participating in communal festivities-that define one as a civilized member of this type of community. (Bell 1997, p. 191)

This is what people of such cultures, in Africa and beyond, believe in-the effectiveness of the ritual. Catherine Bell's discussion of this is extremely relevant again. She wrote:

In approaching issues of ritual density, it has been customary to distinguish the degree to which religious traditions put an emphasis either on correct belief in theological doctrines or on correct performance of behavioral responsibilities. The first style of religion is known as "orthodoxic", from the Greek words orthos (correct, right, straight) and doxa (belief, thought, opinion). The second style is called "orthopraxic", from the Greek praxis, meaning "correct action". As a result of the dominance of Christianity in much of the West, which has tended to stress matters of doctrinal and theological orthodoxy, people may take it for granted that 
religion is primarily a matter of what one believes. Yet in many religious traditions, concerns for what a person believes are often subsumed within more embracing concerns to live according to a code of behavior, a code that usually includes multiple ritual responsibilities. (Bell 1997, p. 191)

This belief in the effectiveness of the ritual for achieving practical goals is directly related to the view that there is no sharp division of the universe into "this world" - the terrestrial world where there is "life" - and "that world"—-the radically different transcendent world where there is "afterlife". The world is one and inhabited first of all by people and spirits of their ancestors. Despite the differences between and the variability of African cultures and their authentic religious systems, even where deities and lesser spirits play an important role, as in many cultures of West Africa, the ancestor cult retained its fundamental role. By means of the ritual, people ask their ancestors' spirits to bestow them good. The ancestor cult dictates that what is most important is to constantly keep proper relations with the ancestors, the most powerful of which can either bless their descendants with all the good or ruin the whole Universe (e.g., Fortes 1965; Grinker et al. 2010, pp. 283-322). Thus, the patterns of behavior in any sphere of life that have already proved their safety in terms of the ancestors' reaction, that is, those followed from generation to generation, are always more preferable than any new ones; the novelty, as such, is seen as something risky, and hence, a priori undesirable. To remain effective, the ritual must be unchanged from the very moment it was approved by higher powers for the first time. Otherwise, if the ritual is not observed strictly in the initial form, it will not be effective any longer. Even more so: the higher powers can bring trouble on the people. In this context, not only the unchangeable ritual, as such, is important-in fact, the whole human life becomes a chain of ritualized behavioral acts. It clearly resonates with the abovementioned Orthodox's vision of the rite as a way of life.

Contrary to their will, the ritual, so important for Orthodox, acquires new social dimensions and inevitably changes its social meaning, being caught between its essential "ritual intimacy" and "ritual publicity" that are changing their forms and scale (Robbins and Sumiala 2016). However, despite this, perception of the ritual as the backbone of religion remains unchanged and shows the continuity of its adherents' views from African pre-Christian (and pre-Muslim) perceptions. Fundamental for Orthodox Christians, including Ugandan Orthodox Christians, rejection of ecumenism as not just tolerance to other religions but as an idea and practical steps towards the organic unity of different Christian denominations (see: Bondarenko 2019, pp. 138-39, 144) is not in line with the worldview related to the ancestor cult. This cult avoids postulating one and only religious truth: people of every village, tribe, or any other unit are protected by the spirits of their ancestors. The spirits of our ancestors are no more real, true, or effective than those of our neighbors' ancestors. The difference is that our ancestors' spirits influence our lives and their ancestors' spirits influence their lives. So, the rejection of ecumenism is a reflection of the aspects of Africans' consciousness brought by monotheism. At the same time, their ritualistic perception of Christianity does demonstrate an important aspect of its continuity from the original worldview. Thus, as the results of fieldwork suggest, continuity from and rupture with the original mentality intertwine in the Ugandan Orthodox Christians' minds.

\section{Conclusions}

An examination of the phenomenon of Ugandan Orthodox Christianity, in the light of modernity that combines colonial legacy, post-coloniality, and globalization, demonstrates the complexity of the process of conversion. The Orthodox do not welcome the increased religious diversity in the country due to the growth in the number and influence of Evangelical, especially Charismatic, denominations, and they see globalization as the path towards cultural degradation. They reject colonialism, post-colonialism, and globalism for facilitating cultural syncretism, and they advocate for strictly adhering to traditions. At the same time, the Orthodox believe that Christianity, which developed outside of Africa and came to Uganda only a century and a half ago, is the most essential part of their own cultural tradition. They spiritually renounce the colonial legacy, post-coloniality, and 
globalization, but the source of what has become the "tradition" for them-Christianity-in Africa is intrinsically related to these phenomena. By rejecting the post-colonial globalist modernity and embracing Orthodox Christianity, they seek to build up an "alternative" modernity. In the process, these Ugandans become a product of modernity. This is a continuation of the endeavor started by the first Ugandan Orthodox a century ago, who saw the "moral community" they wanted to build up as fundamentally different from those of other Christian converts in pre-colonial Buganda and early colonial Uganda- "fervent aspirants to modernity" who "enthusiastically embraced the modernist conception of progress" (Karlström 2004, p. 600).

A belief in one God has established itself in the souls and minds of most Africans, including Ugandan Orthodox Christians. By trying to escape spiritually from what was imposed on them by colonialism, post-coloniality, and globalization, they see the religions brought to the country earlier (Catholicism, Anglicanism, Islam) as part of the legacy they want to reject. However, these people did not turn to African traditional beliefs. At the same time, some Ugandans are dissatisfied with the forms of Christianity associated with colonialists, particularly with Anglicanism and Catholicism. Many Ugandans may also perceive these "older" forms of Christianity to be ordinary and no longer appealing, emotionally exciting, and spiritually inspiring enough. Orthodox Christianity can be a good option for such people. While most of those dissatisfied with "older" Christian denominations convert to "ultramodernist" Pentecostal Churches, some, like Ugandan Orthodox, turn to a conservative "original", "uncorrupted" faith (e.g., Carpenedo 2017; Premawardhana 2018).

More and more scholars working on contemporary Christianity write about its "pentecostalization".

The term pentecostalization refers to the exceptionally fast rise in the number of Pentecostal communities, and the gradual transformation of many other Christian churches and congregations into a single, universal type of charismatic Christianity around the globe ... As a result of this process, particularly in Africa, Asia, and South America, new charismatic and Pentecostal communities are developing, and this process is also taking place within traditional Christian churches. Understood this way, pentecostalization today concerns the Catholic Church worldwide, as well as a great majority of Protestant denominations. (Kobyliński 2016, p. 100; see also, e.g., Anderson 2019; Gooren 2010)

Pentecostalization can push some Ugandans away from not only Pentecostalism, as such, but also from Anglicanism and Catholicism, and make them think about Orthodox Christianity as a spiritual way out or shelter. Besides, they can feel similarity and connection between pentecostalization of the most "traditional" for Uganda forms of Christianity and their movement towards ecumenism as unification of Christian denominations, rejected so emphatically by Orthodox (furthermore, ecumenical trends have presented in Ugandan Anglican and Catholic Churches for quite a long time (Carney 2017)).

However, it becomes clear that paradoxically, the Orthodox's anti-globalist encounter with modernity has the same roots and background as the better studied Pentecostal "ultramodernism". Both of these phenomena can be read as different outcomes of the search for proper expressions of spirituality that is central to African cultures-an immanent religious feeling regardless of a person's particular religion that forms an integral part of the African system of socio-cultural values, as observers of different African cultures note (e.g., Mbiti 2001; Kanu 2010, pp. 152, 157-58; Olasunkanmi 2015, p. 9). This feeling does not simply imply a belief in the "supernatural". It entails the conduct of a way of life based on and directed by the feeling of a constant presence of the higher powers in the world. What also seemingly unexpectedly brings together in the African context such different religions as Orthodox Christianity and Pentecostalism is that they both emphasize and actualize non-dogmatic aspects of Christian faith. However, the aspects they underscore are significantly different. While Pentecostalism, as well as other forms of Charismatic Christianity, emphasizes the emotional side, Orthodox in Uganda concentrates on the ritual.

Pentecostalism and the Orthodox tradition show different faces of the spiritual turn observable in present-day Africa (see also: Bondarenko 2019, pp. 151-53). In particular, the example of Ugandan 
canonic and old-rite Orthodox Christians demonstrates how religiosity can acquire clearly marked anti-globalist directionality in a post-colonial setting, if globalization is seen as destroying traditional home-born cultures by mixing them with others, especially Western cultures. This kind of anti-globalism has nothing to do with world politics and economics, as most Ugandan Orthodox are not educated and enlightened enough to be versed in international and transnational affairs. This is a kind of spiritual anti-globalism. By emphasizing in interviews how important it is uphold traditions, they see both globalization and ecumenism as chaotic and destructive for the "true faith" and by combining "traditions" that should never be fused. The stories of conversion to Orthodox Christianity in Uganda speak volumes about the tension between religion, post-colonial modernity, and cultures in present-day sub-Saharan Africa.

Author Contributions: Conceptualization, D.M.B. and A.V.T.; Data curation, D.M.B.; Formal analysis, D.M.B. and A.V.T.; Funding acquisition, D.M.B.; Investigation, D.M.B. and A.V.T.; Methodology, D.M.B. and A.V.T.; Project administration, D.M.B.; Supervision, D.M.B.; Writing—original draft, D.M.B. and A.V.T.; Writing-review \& editing, D.M.B. All authors have read and agreed to the published version of the manuscript.

Funding: This article is an output of a research project implemented as part of the Basic Research Program at the National Research University Higher School of Economics.

Acknowledgments: The authors are sincerely grateful to this special issue guest editors, Jason Bruner and David Dmitri Hurlbut, for inviting to contribute to it. The authors appreciate greatly Nikola Bobkov's immense assistance in organizing research, Vladimir L. Klyaus and Alina O. Lapushkina's participation in collecting and processing the evidence, Larisa A. Andreeva and Oleg I. Kavykin's participation in compiling the questionnaire and interview plan. Last but not least, we feel obliged to those members of the Orthodox Christian communities who assisted us in our work in many ways and to all the informants who were so kind as to spend their time in frank communication.

Conflicts of Interest: The authors declare that no conflicts of interest can be identified with respect to the present article.

\section{References}

Alava, Henni, and Jimmy Spire Ssentongo. 2016. Religious (De)politicization in Uganda's 2016 Elections. Journal of Eastern African Studies 10: 677-92. [CrossRef]

Anderson, Benedict. 2006. Imagined Communities: Reflections on the Origin and Spread of Nationalism. London and New York: Verso.

Anderson, Allan Heaton. 2019. Charismatic Churches and the Pentecostalization of African Christianity. In The Oxford History of Protestant Dissenting Traditions, Vol. IV. The Twentieth Century: Traditions in a Global Context. Edited by Jehu J. Hanciles. Oxford: Oxford University Press, pp. 52-72.

Anonymous. 1977. Amin Bans All but Three Christian Churches as Risks. The New York Times, September 21. Available online: https://www.nytimes.com/1977/09/21/archives/amin-bans-all-but-three-christian-churchesas-risks.html (accessed on 13 April 2020).

Anonymous. 2015. Khirotoniia Staroobriadcheskogo Sviashchennika Dlia Ugandy [Ordination of an Old Believers Priest for Uganda]. Available online: http://rpsc.ru/news/hirotoniya-staroobryadcheskogo-svyashhennikadlya-ugandy/ (accessed on 19 December 2018).

Anonymous. 2017. Kiimba Ioakim ['Kiyimba, Joachim]. Available online: https://drevo-info.ru/articles/13671688. html (accessed on 19 December 2018).

Appadurai, Arjun. 1996. Modernity at Large: Cultural Dimensions of Globalization. Minneapolis: University of Minnesota Press.

Babst, Gordon A. 2011. Moral Community. In Encyclopedia of Global Justice. Edited by Deen K. Chatterjee. Dordrecht: Springer, pp. 710-11.

Balandier, Georges. 1970. The Sociology of Black Africa: Social Dynamics in Central Africa. Translated by Douglas Garman. London: Andre Deutsche.

Bell, Catherine. 1997. Ritual: Perspectives and Dimensions. New York and Oxford: Oxford University Press.

Ben-Rafael, Eliezer, and Yitzak Sternberg, eds. 2005. Comparing Modernities: Pluralism versus Homogenity: Essays in Homage to Shmuel N. Eisenstadt. Leiden: Brill.

Bhambra, Gurminder K. 2007. Rethinking Modernity: Postcolonialism and the Sociological Imagination. Basingstoke: Palgrave. 
Bitrus, Ibrahim S. 2017. Globalizing Impact of Modernity in Africa. Journal of Globalization Studies 8: 68-83.

Bobkov, Nikola. 2017. Staroobriadchestvo v Ugande. Pervye shagi [Old Believers in Uganda. First Steps]. Traditsionnaja kul'tura 2: 28-34.

Bondarenko, Dmitri M. 2019. In Search of the True Faith: The Appearance of Orthodox Old Believers in Uganda and Spiritual Anti-globalism in Contemporary Africa. Exchange. Journal of Contemporary Christianities in Context 48: 127-55. [CrossRef]

Brenner, Louis. 1989. 'Religious' Discourses in and about Africa. In Discourse and Its Disguises: The Interpretation of African Oral Texts. Edited by Karin Barber and Paulo Fernando de Moraes Fraias. Birmingham: Birmingham University Press, pp. 87-108.

Caldeira, Isabel. 2016. Memory is of the Future: Tradition and Modernity in Contemporary Novels of Africa and the African Diaspora. E-cadernos CES 26. Available online: http://journals.openedition.org/eces/2126 (accessed on 14 April 2020).

Carney, Jay J. 2017. The Politics of Ecumenism in Uganda, 1962-1986. Church History 86: 765-95. [CrossRef]

Carpenedo, Manoela. 2017. Collective Memory in the Making of Religious Change: The Case of 'Emerging Jews' Followers of Jesus. Religion 48: 83-104. [CrossRef]

Comaroff, Jean, and John L. Comaroff. 1993. Introduction. In Modernity and Its Malcontents: Ritual and Power in Postcolonial Africa. Edited by Jean Comaroff and John L. Comaroff. Chicago: University of Chicago Press, pp. xi-xxxi.

Comaroff, Jean, and John L. Comaroff. 1997. Of Revelation and Revolution: The Dialectics of Modernity on a South African Frontier. Chicago: University of Chicago Press, vol. 2.

Deutsch, Jan-Georg, Peter Probst, and Heike Schmidt, eds. 2002. African Modernities: Entangled Meanings in Current Debate. Portsmouth: Heinemann.

Eisenstadt, Shmuel N. 2000. Multiple Modernities. Daedalus 129: 1-29.

Eisenstadt, Shmuel N., ed. 2002. Multiple Modernities. London: Routledge.

Eisenstadt, Shmuel N. 2003. Comparative Civilizations and Multiple Modernities (2 vols). Leiden and Boston: Brill.

Ferguson, James. 1999. Expectations of Modernity: Myths and Meanings of Urban Life on the Zambian Copperbelt. Berkeley: University of California Press.

Fortes, Meyer. 1965. Some Reflections on Ancestor Worship in Africa. In African Systems of Thought: Studies Presented and Discussed at the Third International African Seminar in Salisbury, December, 1960. Edited by Meyer Fortes and Germaine Dieterlen. London: Oxford University Press, pp. 122-42.

Gaonkar, Dilip Parameshwar, ed. 2001. Alternative Modernities. A Millennial Quartet Book. Durham: Duke University Press.

Gooren, Henri. 2010. The Pentecostalization of religion and Society in Latin America. Exchange. Journal of Contemporary Christianities in Context 39: 355-76. [CrossRef]

Grinker, Roy Richard, Stephen C. Lubkemann, and Christopher Burghard Steiner, eds. 2010. Perspectives on Africa: A Reader in Culture, History, and Representation. Malden and Oxford: Wiley-Blackwell.

Hayes, Stephen. 1996. Orthodox Mission in Tropical Africa. Missionalia 24: 383-98.

Herbel, D. Oliver. 2014. Turning to Tradition: Converts and the Making of an American Orthodox Church. Oxford and New York: Oxford University Press.

Imafidon, Elvis. 2020. Alterity, African Modernity, and the Critique of Change. In Handbook of African Philosophy of Difference. Handbooks in Philosophy. Edited by Elvis Imafidon. Cham: Springer, pp. 50-68.

Isiko, Alexander Paul. 2019. State Regulation of Religion in Uganda: Fears and Dilemmas of Born-Again Churches. Journal of African Studies and Development 11: 99-117.

Kanu, Macaulay A. 2010. The Indispensability of the Basic Social Values in African Tradition: A Philosophical Appraisal. Ogirisi: A New Journal of African Studies 7: 149-61. [CrossRef]

Kanu, Ikechukwu Anthony, Catherine Chiugo Kanu, and Kanayo Nwadialor, eds. 2018. African Governance and Development Issues in a World of Change: The Changing Patterns of a Static Universe. Bloomington: Author House.

Karlström, Mikael. 1999. The Cultural Kingdom in Uganda: Popular Royalism and the Restoration of the Buganda Kingship. Ph.D. dissertation, Department of Anthropology, University of Chicago, Chicago, IL, USA. 2 vols.

Karlström, Mikael. 2004. Modernity and Its Aspirants: Moral Community and Developmental Eutopianism in Buganda. Current Anthropology 45: 595-619. [CrossRef] 
Kato, Theodore, ed. 2014. Orthodox Church in Uganda: Challenges for the Continuation. Kampala: Holy Metropolis of Kampala and All Uganda.

Kivengere, Festo. 1977. I Love Idi Amin: A Story of Triumph under Fire in the Midst of Suffering and Persecution in Uganda. Old Tappan: New Life Ventures.

Kobyliński, Andrzej. 2016. The Global Pentecostalization of Christianity and Its Ethical Consequences. Chicago Studies 55: 100-20.

Larrain, Jorge. 2000. Identity and Modernity in Latin America. Cambridge, Polity and Malden: Blackwell.

Lee, Ralph, and Daniel Seifemichael. 2017. Orthodox. In Christianity in Sub-Saharan Africa. Edited by Kenneth R. Ross, J. Kwabena Asamoah-Gyadu and Todd M. Johnson. Edinburgh: Edinburgh University Press, pp. 264-77.

Lugo, Luis, and Alan Cooperman, eds. 2010. Tolerance and Tension: Islam and Christianity in Sub-Saharan Africa. Washington: Pew Forum on Religion \& Public Life.

Mamdani, Mahmood. 2018. Citizen and Subject: Contemporary Africa and the Legacy of Late Colonialism. Princeton and Oxford: Princeton University Press.

Mami, Fouad. 2011. Between Modernity and Tradition: African Identity in a State of Transition. University of Bucharest Review. Literary and Cultural Studies Series (New Series) 1: 113-26.

Marett, Robert R. 1914. The Threshold of Religion. London: Methuen.

Martin, David. 2009. The Relevance of the European Model of Secularization in Latin America and Africa. In Secularization and World Religions. Edited by Klaus Wiegandt and Hans Joas. Liverpool: Liverpool University Press, pp. 278-95.

Mbembe, Achille. 2005. De La Postcolonie, Essai sur L'imagination Politique dans L'afrique Contemporaine. Paris: Karthala.

Mbiti, John. 2001. General Manifestations of African Religiosity. Paper presented at the First Meeting of the Standing Committee on the Contributions of Africa to the Religious Heritage of the World, Enugu, Nigeria, 8-13 January. Available online: https://ru.scribd.com/document/33739700/General-Manifestations-of-African-Religiosity (accessed on 19 December 2019).

Msellemu, Sengulo A. 2004. Globalisation is Neocolonialism. Vostok/Oriens 6: 90-96.

Nkwi, Walter Gam. 2015. African Modernities and Mobilities. An Historical Ethnography of Kom, Cameroon, C. 1800-2008. Buea: Langaa RPCIG.

Offiong, Daniel A. 2013. Globalisation and Africa: Reverse Robin Hoodism. Lagos: Apex Books.

Ogundowole, E. Kolawole. 2004. Philosophy and Society. Lagos: Correct Counsels.

Olasunkanmi, Aborisade. 2015. A Philosophical Appraisal of Basic Cultural Values in African Tradition. International Journal of Politics and Good Governance 6: 1-12.

Olurode, Lai. 2003. Gender, Globalisation and Marginalisation in Africa. Africa Development 28: 67-88. [CrossRef]

Osterhammel, Jürgen. 2010. Colonialism: A Theoretical Overview. Translated by Shelley L. Frisch. Princeton: Markus Wiener Publishers.

Palmer, Jack. 2018a. Entanglements of Modernity, Colonialism and Genocide: Burundi and Rwanda in Historical-Sociological Perspective. London: Routledge.

Palmer, Jack. 2018b. S.N. Eisenstadt and African Modernities: Dialogue, Extension, Retrieval. European Journal of Social Theory, November 15. Available online: http://eprints.whiterose.ac.uk/136517/3/SN\%20Eisenstadt\% 20and\%20African\%20Modernities\%20final\%20version.pdf (accessed on 14 April 2020).

Peterson, Derek R. 2012. Ethnic Patriotism and the East African Revival: A History of Dissent, c. 1935-1972. Cambridge: Cambridge University Press.

Premawardhana, Devaka. 2018. Faith in Flux: Pentecostalism and Mobility in Rural Mozambique. Philadelphia: University of Pennsylvania Press.

Preyer, Gerhard, and Michael Sussmann, eds. 2015. Varieties of Multiple Modernities. Leiden: Brill.

Robbins, Joel. 1998. Becoming Sinners: Christianity and Desire among the Urapmin of Papua New Guinea. Ethnology 37: 299-316. [CrossRef]

Robbins, Joel. 2001. God is Nothing but Talk: Modernity, Language, and Prayer in a Papua New Guinea Society. American Anthropologist 103: 901-12. [CrossRef]

Robbins, Joel, and Johanna Sumiala. 2016. Ritual Intimacy-Ritual Publicity: Revisiting Ritual Theory and Practice in Plural Societies. Suomen Antropologi 41: 1-5.

Schmidt, Volker H. 2006. Multiple Modernities or Varieties of Modernity? Current Sociology 54: 77-97. [CrossRef] 
Slagle, Amy. 2011. The Eastern Church in the Spiritual Marketplace: American Conversions to Orthodox Christianity. De Kalb: Northern Illinois University Press.

Smith, Wilfred Cantwell. 1979. Faith and Belief. Princeton: Princeton University Press.

Ssorin-Chaikov, Nikolai. 2016. Soviet Debris: Failure and the Poetics of Unfinished Construction in Northern Siberia. Social Research: An International Quarterly 83: 689-721.

Therborn, Göran. 2003. Entangled Modernities. European Journal of Social Theory 6: 293-305. [CrossRef]

Uganda Bureau of Statistics. 2016. The National Population and Housing Census 2014-Main Report. Kampala: Uganda Bureau of Statistics.

Uganda Orthodox Church. 2019. Available online: http://www.ugandaorthodoxchurch.co.ug/ (accessed on 21 December 2019)

Urushev, Dmitri. 2016. Russkoe Staroobriadchestvo: Traditsii, Istoriia, Kul'tura (Russian Old Believers: Traditions, History, Culture). Moscow: Ėksmo.

Van Den Toren, Benno, and Willem J. de Wit. 2015. Secularization and Discipleship in Africa: Conclusions and Recommendations. Cairo Journal of Theology 2: 152-60.

Wagner, Peter. 2001. Theorizing Modernity. Inescapability and Attainability in Social Theory. London: SAGE.

Wagner, Peter. 2008. Modernity as Experience and Interpretation: A New Sociology of Modernity. London: Polity Press. Wagner, Peter, ed. 2015. African, American and European Trajectories of Modernity: Past Oppression, Future Justice? Edinburgh: Edinburgh University Press.

Wallerstein, Immanuel, ed. 1966. Social Change: The Colonial Situation. New York: John Wiley \& Sons.

Weber, Max. 1953. From Max Weber: Essays in Sociology. Edited by Hans Heinrich Gerth and C Wright Mills. New York: Oxford University Press.

(C) 2020 by the authors. Licensee MDPI, Basel, Switzerland. This article is an open access article distributed under the terms and conditions of the Creative Commons Attribution (CC BY) license (http://creativecommons.org/licenses/by/4.0/). 
Article

\title{
Hagiography as Source: Gender and Conversion Narratives in The Book of the Saints of the Ethiopian Church
}

\author{
Anna Redhair Wells \\ Department of Religion, Baylor University, Waco, TX 76706, USA; Anna_Wells1@baylor.edu \\ Received: 29 May 2020; Accepted: 18 June 2020; Published: 23 June 2020
}

\begin{abstract}
Drawing on the work of Jeanne-Nicole Mellon Saint-Laurent, this essay proposes utilizing hagiographies from the The Book of the Saints of the Ethiopian Church, a fifteenth-century Ethiopian collection of saints' lives, to explore various aspects of conversion. Other scholars employ a similar approach when analyzing hagiographical literature found in medieval Europe. While acknowledging that these texts do not provide details about the historical experience of conversion, they can assist scholars in understanding the conception of conversion in the imagination of the culture that created them. This essay specifically focuses on the role of women in conversion throughout the text and argues that, although men and women were almost equally represented as agents of conversion, a closer examination reveals that their participation remained gendered. Women more frequently converted someone with whom they had a prior relationship, especially a member of their familial network. Significantly, these observations mirror the patterns uncovered by contemporary scholars such as Dana Robert, who notes how women contributed to the spread of Christianity primarily through human relationships. By integrating these representations of conversion from late medieval Ethiopia, scholarship will gain a more robust picture of conversion in Africa more broadly and widen its understanding of world Christianity.
\end{abstract}

Keywords: Ethiopian Orthodox Church; religious conversion; women; representation; medieval Christianity; hagiography

\section{Introduction}

If the entry for "conversion" in the Encyclopedia of Religion serves as any indication, it is difficult for scholars to agree on what exactly constitutes conversion (Rambo and Farhadian 2005). For several decades, A. D. Nock's description of conversion as "the reorientation of the soul of an individual, his deliberate turning from indifference or from an earlier form of piety to another, a turning which implies consciousness that a great change is involved, that the old was wrong and the new is right" dominated much of the conversation on the topic (Nock 1933). More recently, this definition has received substantial criticism, and scholars from diverse fields with different approaches have proposed new ways of understanding this religious experience (Jindra 2014). ${ }^{1}$

With the exponential growth of African Initiated Churches (AIC) and a religiously plural environment, Africa constitutes a significant location for the study of conversion (Horton 1971). ${ }^{2}$ Most research on conversion in Africa focuses on the modern period, yet the continent is also home to one of the earliest branches of Christianity that survives today, the Ethiopian Orthodox Church

1 For a helpful overview of the myriad of approaches to and definitions of conversion, see the introduction.

2 Robin Horton developed an interpretation of why traditional religions in Africa moved towards (i.e., converted to) world religions. His theory remains controversial and demonstrates one approach to conversion in Africa. 
(Phillipson 2012). ${ }^{3}$ Several scholars have considered the historic experience of conversion in Ethiopia in the pre-modern period, paying particular attention to the relationship between Christianity, Islam, and Judaism in the region (Kaplan 1984, 2004; Abir 1980). Religious adherence and conversion often depended on who controlled a particular region, which changed frequently in the medieval period as both Christianity and Islam expanded in Ethiopia. Both Christianity and Islam integrated local religious elements, making the historical reality of conversion less clear-cut than it sometimes appears (Fauvelle 2020). These studies shed light on the activities of male monastics and merchants as agents of conversion for their respective religions.

While the emphasis on the historical experience of conversion remains valuable, it often leaves out consideration of women's participation. This paper intends to take a different approach by examining the representation of conversion in a fifteenth-century compilation of saints' lives known as The Book of the Saints of the Ethiopian Church. Although hagiography can be a difficult source to use for historical research, it can also be a fruitful one. While these accounts do not necessarily align with the historical experience of conversion in Ethiopia, they do help scholars understand the conception of ideal conversion in the imagination of the Ethiopian Orthodox Church. By analyzing the conversion narratives contained within the text, this paper argues that The Book of the Saints portrayed both men and women as agents of conversion, yet their representation remained gendered (Sterk 2010a, 2010b). ${ }^{4}$ Women more often converted someone with whom they had a prior, personal relationship, whereas men participated in conversion through their officially recognized roles within the ecclesiastical structure. This study hopes to contribute to the broader understanding of the ways in which women contributed to the movement of Christianity outside of traditional missionary sources.

\section{Hagiography as Source}

Hagiographical texts like The Book of the Saints present challenging obstacles as sources. As Jeanne-Nicole Mellon Saint-Laurent observes in her work on early Syriac saints' lives, hagiography does not fit neatly into the genre of history, fiction, or scripture, yet it contains characteristics and conventions from each (Saint-Laurent 2015). Hagiography weaves these three types of literature together in a complex, multi-layered text which can prove difficult to unravel. Additionally, no set criteria exist for evaluating and interpreting hagiographical literature. This lack of methodological coherence creates an additional hurdle when working with saints' lives. The issues highlighted by Saint-Laurent are not confined to Syriac sources; rather, hagiographical accounts prove problematic across geographic location and time frame.

Scholars who work with hagiographies diverge in their approaches to the texts, especially their value as historical sources. Looking at the late medieval European context, historian R. N. Swanson points out that "exactly what the appropriate response should be to medieval saints' lives is a matter of considerable debate" (Swanson 1995). For example, scholars disagree over how a hagiography's intended audience might have interpreted the story, particularly how they understood the more fantastic elements of saints' lives. Hagiographies of martyrs often employed detailed descriptions of gruesome tortures and incredible miracles before a saint's martyrdom. The Legenda Aurea, the most popular compilation of saints' lives in medieval Europe, included numerous such accounts of martyrdom (Duffy 2012). ${ }^{5}$ Eamon Duffy notes that these sections, among others, caused later humanist and Protestant scholars to attack the historical value of the hagiographies in the Legenda Aurea, an

3 According to the church historian Rufinus, a Syrian Christian named Frumentius converted the Askumite king, Ezana, in the mid-fourth century (Aksum was an ancient kingdom that predated the development of the modern nation of Ethiopia). Athanasius consecrated Frumentius as the first bishop of Ethiopia. While Rufinus' account is difficult to verify, numismatic and archaeological evidence support King Ezana's conversion to Christianity in the mid-fourth century.

4 Andrea Sterk recently took a similar approach in regard to gender and representation in her two-part article on female missionaries in the Christianization of the east in the post-Constantinian period.

5 Compiled in the thirteenth century as a handbook for preachers by Jacobus de Voragine, a Dominican friar, the Legenda Aurea included entries for the Roman Catholic Church's major liturgical holidays and lives of the saints. 
attitude that persisted for several centuries. ${ }^{6}$ Taken together, the methodological concerns raised by Saint-Laurent, Swanson, and Duffy provide a brief overview of the complexity associated with using hagiographies as sources.

In light of these difficulties, it is reasonable to wonder how scholars can use saints' lives as sources at all, yet the authors considered above provide several possible answers. Duffy acknowledges the difficulty in separating historical events from miraculous occurrences, but still argues for the value of Voragine's text as a reflection of the "most pressing preoccupations of the Church of his own day" (Duffy 2012). Rather than looking for historical information about a particular saint, Duffy suggests using the Legenda Aurea as evidence for the culture that produced the text, in this case, the thirteenth-century Roman Catholic Church. Swanson agrees with Duffy, arguing that to judge or evaluate saints' lives in "purely historical terms" is misguided (Swanson 1995). Instead, he advocates for an approach to saints' lives that highlights their spiritual and devotional content. Medieval Christians in Europe privileged the moral lesson or spiritual truth exemplified by the saint over the text's historical accuracy, and scholars should utilize a similar lens when analyzing saints' lives.

Saint-Laurent makes similar conclusions and proposes additional ways to utilize hagiographies as sources. Her work builds on the assumption that "sacred narratives shed light on the beliefs and cultural ideas of the people who wrote them," and stresses the importance of looking for shared motifs, themes, and symbols recurring throughout the narratives (Saint-Laurent 2015). The common elements repeated in these stories can point scholars toward issues the author or compiler of the text found most important and wanted to emphasize. Finally, Duffy views the Legenda Aurea as "the distillation of both the imagination and the soul of the Christian Middle Ages" (Duffy 2012). While The Book of the Saints was not as ubiquitous for late medieval Ethiopian Christianity as the Legenda Aurea was for medieval Europe, Duffy's idea of Christian imagination proves useful. Hagiographical texts contained representations of the Christian imagination regarding different aspects of the faith. Saints' lives helped shape the boundaries of Christian expression and provided models for the hearers or readers to emulate. The representations of sanctity in hagiographies influenced the audience's understanding of what it meant to be holy and how one could achieve holiness. Employing the methods and considerations discussed here, this paper seeks to analyze the representations of conversion contained in The Book of the Saints through the lens of gender.

Although hagiography constitutes one of the most important sources for Ethiopia's medieval history, The Book of the Saints has received little scholarly attention. In his masterful study Church and State in Ethiopia 1270-1527, Tadesse Tamrat relies heavily on saints' lives for information about significant religious figures and events (Tamrat 1972). Steven Kaplan wrote a key article addressing the use of hagiography in studying medieval Ethiopia (Kaplan 1981; Rossini 1937). ${ }^{7}$ He argued against earlier scholarship that evaluated the reliability of a saint's life based on how quickly after his or her life the text was written. Kaplan advocated a new approach but maintained that only saints' lives written about Ethiopians by Ethiopians should be considered Ethiopian hagiography. His recommendation colored much subsequent scholarship on Ethiopian saints' lives and placed The Book of the Saints outside consideration. In contrast, some of the most revered saints in Europe were not Europeans, nor were their lives written by Europeans.

While Tamrat and Kaplan's work mainly considered male saints' lives, Selamawit Mecca has written several articles on Ethiopian female saints (Mecca 2006, 2009). Following Kaplan's limitations, however, Mecca only examines the hagiographies of female saints from Ethiopia. While Kaplan and Mecca's studies are helpful, this paper departs from their approach and suggests that saints' lives

6 For further discussion of the reception of the Legenda Aurea by humanist and protestant scholars, see (Reames 1985).

7 Kaplan's article is in part an argument against the viewpoint of the prolific scholar of Ethiopia, Conti Rossini. Rossini developed a "date of composition" approach that assigned historical value to hagiography based on how quickly it was written after a saint's life. Kaplan rightfully finds this approach problematic, but his approach is also problematic. See (Kaplan 1981). For Rossini's "date of composition view", see (Rossini 1937). 
written about non-Ethiopian saints can still provide valuable information about medieval Ethiopia. Most of the saints' lives in The Book of the Saints are of non-Ethiopians, but the text's acceptance by the Ethiopian Orthodox Church allows for consideration of the way it represents conversion and gender.

\section{Representations of Conversion}

The Book of the Saints included narratives about biblical figures and the lives of early Christian saints as well as saints from Coptic and Ethiopian sources. The text organized the hagiographical accounts of over one thousand holy men and women according to the Ethiopian Orthodox calendar, which has thirteen months, and assigned several saints to each day (Budge 1928; Guidi 1911). ${ }^{8}$ The lives ranged in length from a few lines to multiple pages, and drew on a wide variety of sources including the Old and New Testaments, Coptic traditions, and local legends. Scholars posit that the text originated in Greek and Syriac sources and existed in Coptic and Arabic versions before it was translated into Ge'ez, the written Ethiopian language. ${ }^{9}$ Based on manuscript evidence, the earliest Ethiopian translation occurred in the late fourteenth century and simply copied the lives of saints venerated by Coptic Christians (Budge 1928). As the document circulated throughout Ethiopia, however, scribes added local saints to the compilation, and it quickly gained a distinctly Ethiopian viewpoint.

Over time, this collection of saints' lives became part of the liturgy in the Ethiopian Orthodox Church and was read aloud during the service. Significantly, the work's inclusion in the church's liturgy allowed the saints' lives to reach a wider audience. The manuscripts preserved today take up hundreds of leaves, which corresponded to a high production cost in the fifteenth century. Most ordinary Christians would not have had access to these narratives if they were not read aloud, but the place of the saints' lives in the liturgy allowed these stories to shape the conceptions of conversion and sanctity for Ethiopian Christians. Although the text included non-Ethiopian saints, the Book of the Saints was widely copied and exists in a number of manuscripts today as a testament to its significance for the Ethiopian Orthodox Church.

In regard to conversion, the overwhelming majority of the saints' lives contained in The Book of the Saints fall into one of two categories..$^{10}$ The first type includes no description of a conversion experience. These entries either deal with appointment to positions in the ecclesiastical hierarchy or relate the life of a holy man or woman who accepted and followed the faith seemingly from birth. This is not to say that these men and women did not undergo a conversion experience of some kind, only that the entry for their life does not include a description of that conversion that can be examined on the basis of gender. An example of this lack of conversion narrative can be found on the twenty-eighth of the month of Miyazya in the life of Saint Melius. The beginning of the entry relates, "On this day Saint Melius became a martyr. This holy man was a strenuous ascetic and fighter, and one who kept vigil all the days of his life ..." (Budge 1928). The remainder of the text explains the story of his martyrdom at the hands of two pagan princes and includes several miracles as evidence of his holiness. The entry does not, however, explain who converted the saint to the faith, which is the specific focus of this paper. Like the life of Saint Melius, a substantial number of the saints' lives in The Book of the Saints lead the reader to assume the conversion of their subjects. The text, therefore, does not include a conversion narrative that can be analyzed through its intersection with gender. Without an explicit description of the conversion experience, conclusions cannot be drawn regarding the agent of conversion.

8 The Book of the Saints is alternatively referred to in scholarship as the Ethiopian Synaxarium or Senkessar. For the sake of consistency, I will refer to the text as The Book of the Saints throughout the paper. Although his dating has been challenged, for more information on the background of the text and its sources see (Guidi 1911).

9 Today, the official language in Ethiopia is Amharic, and Ge'ez has been relegated to a liturgical language with a use similar to that of Latin in the Roman Catholic Church.

10 A portion of the entries in The Book of the Saints commemorate biblical events or stories such as Christ's ascension or the life of Abraham and Sarah. Most of these biblical accounts were excluded from consideration as "conversion narratives" on the basis that they do not explicitly address the conversion experience of the biblical figure. A select few dealing with Paul's missionary activity do appear in the paper's calculations, namely, St. Timothy, St. Onesimus, and St. Dionysius. 
Another significant portion of the saints' lives represented in The Book of the Saints features the faith of a saint's parents. In several instances, a particular saint's mother and father both believed in Christ and the reader can infer that they raised the holy man or woman as a Christian. The life of Abraham the anchorite on the thirtieth of Tekemt serves as an example. His account opens, "On this day died the holy father, the fighter who prayed always, Abraham the anchorite. This holy man was a native of the city of Manuf, and his parents feared God, and served Christ, and they were exceedingly rich in the possessions of this world. When he had grown to man's estate, this holy man wished to put on the garb of the ascetic life" (Budge 1928). Abraham did not suffer martyrdom, but led an extreme version of the ascetic life, eating only a few beans every night and dressing in rags. Again, the text did not include an explicit conversion narrative. It can be assumed that the parents passed their faith to the holy man, but little to no attention is given to this part of the story. In an effort to maintain a level of scholarly rigor, the conclusions regarding the agent of conversion in this paper will be based on clear conversion descriptions rather than the assumptions necessary in this type of account. Due to the concerns highlighted in both of the categories of conversion considered above, these instances will not be analyzed in the remainder of the paper.

After removing the two types of entries enumerated above, sixty-one explicit conversion narratives remained. Statistically, The Book of the Saints depicted men and women as agents of conversion at a similar rate. Of the sixty-one conversion narratives identified in the text, twenty-five of the saints were converted by men, while twenty-three of the saints were converted by women. The gender of the agent of conversion for two of the saints was not specified in the account; one involved a group of children, and the other saint converted after observing the steadfastness of several Christian martyrs. The remaining eleven saints converted either through a direct experience with God or after witnessing a miracle. This breakdown illustrates the possibility of someone experiencing conversion without human agency, but the overwhelming majority of saints converted through their interaction with another person. The text did not limit a Christian from converting someone else on the basis of gender, including an almost equal number of representations of men and women as the agent of conversion.

While the text did present men and women as equally capable of converting someone else, a closer examination of these stories reveals that their participation as agents of conversion was still gendered. After analyzing the relationship between the believer and the convert, stark differences based on gender emerge. Not including those saints converted by God's direct intervention or the two agents of unspecified gender, twenty-seven saints had no prior relationship with the believer who converted them to Christianity. Conversely, twenty-one saints experienced conversion as a result of their personal relationship with a believer, often a family member or friend. Of those who were converted by someone they already knew, the agent of conversion in one instance was a male friend, one was the saint's father, and another was converted by a female nurse. The other eighteen saints who came to faith through someone they had a prior relationship with were converted by female family members, such as their mother, daughter, sister, or wife. The conclusions of this analysis hold significance for the discussion of conversion in relation to gender.

Based on the data from The Book of the Saints, a male believer had an existing relationship with the person he converted only twice. ${ }^{11}$ This means that, of the twenty-five men identified as agents of conversion in the text, twenty-three of them had no prior connection to the person they converted. In contrast, nineteen of the twenty-three women represented as agents of conversion in the text had some sort of history with the person they converted, often through a familial relationship. ${ }^{12}$ Although The Book of the Saints represented men and women as agents of conversion almost equally from a numerical perspective, the depiction remained gendered as men were more likely to convert a stranger whereas women more frequently converted someone they already knew.

11 The only two male believers who had a prior relationship with the person they converted were the male friend and the father mentioned previously.

12 This number includes the eighteen female family members and the female nurse. 
Not only were men more likely to convert a stranger, but they almost always had the opportunity to convert someone because of their ecclesiastical position or reputation for teaching. On the fifteenth of Hamle, The Book of the Saints commemorates the death of Ephraim the Syrian. This saint's father was a pagan priest who worshiped idols and despised the Christian faith. Ephraim left his father's house and traveled to the nearby bishop, Abba Jacob, "who admonished him, taught him, and baptized him with Christian baptism" (Budge 1928). Ephraim and Abba Jacob did not have a relationship beforehand, but Ephraim sought him out because of his position as a bishop. In a similar story, Saint Ablarius was raised by pagan parents. He loved learning, but his hometown could not provide him with the education he desired, so he moved to Alexandria. He learned from experts in several areas until "a divine zeal moved within him to learn the doctrine of the church, and he enquired for the books of the church and certain men gave them to him, and he read them and understood them" (Budge 1928). The archbishop of Alexandria, Iskander, explained the more obscure texts to him, allowing him to understand the faith and be baptized. Iskander encountered Ablarius and converted him to Christianity through his official position as bishop. In both cases, membership in the ecclesiastical hierarchy of the church situated Jacob and Iskander as agents of conversion.

Other men had the opportunity to convert strangers through their reputation for teaching. A pagan king brought Saint George to his palace to pray and read the psalms because he was known as a great Christian teacher. After Saint George finished speaking, the king's wife, Queen Alexandra, "asked him to interpret them [the psalms] to her, and he interpreted them and made clear to her the Godhead of our Lord Jesus Christ; and his words entered her heart and she believed on the Lord Jesus Christ" (Budge 1928). Her husband, however, continued to worship idols, and Saint George laughed at him. When the king came to his wife for comfort after being embarrassed by the saint, she admonished him for opposing the Christians. Enraged, the king tortured her until she received martyrdom. The text presents George as a recognized teacher who had the opportunity to convert the queen as a result of his reputation.

Men who converted others to the faith sometimes offered instruction whether it was solicited or not, as in the case of Saint Pelagia. According to the text for the eleventh of Tekemt, Saint Pelagia and her parents followed a pagan faith, leading her to a corrupt lifestyle. Pelagia lived in a brothel, played the tambourine, sang and danced, and entertained the people (Budge 1928). A bishop and holy man named Paul found her and rebuked her lifestyle, reminding her of the eternal punishment that awaited her. After his condemnation, "she believed on our Lord Christ through him, and she confessed to him everything which she had done, and he encouraged her, and taught her not to despair through repentance, and the mercy of God" (Budge 1928). Paul had no prior relationship with Pelagia, but when he witnessed her wicked lifestyle, his reputation as a holy man allowed him to censure her, which led to her conversion. Almost all of the men represented in the text as agents of conversion occupied a position within the church structure or had a reputation for teaching. They did not convert individuals with whom they had a personal relationship; instead, conversion occurred as a result of the public nature of their preaching or teaching.

In contrast, women rarely converted strangers through preaching or teaching. Instead, women in the text utilized their personal relationships when they participated as agents of conversion. On the twenty-third of Hamle, The Book of the Saints honors the martyrdom of Saint Marina. According to the text, Saint Marina was the daughter of the pagan emperor Decius. Her mother died when she was only five years old, so her father entrusted her to a nurse outside the city. The nurse was a Christian and taught Marina everything about the faith (Budge 1928). After her nurse told her stories about believers who remained steadfast in the face of martyrdom, Marina wanted to follow their example and was martyred by an unbelieving governor. In this example, the Christian nurse utilized her close personal relationship with Marina to convert her to faith in Christ. Women participated in conversion without holding official positions or being recognized as impressive teachers. Their contributions to Christian conversion developed as an extension of their jobs or familial relationships. 
As noted above, familial bonds constituted a significant portion of women's participation as agents of conversion in Ethiopian saints' lives. Seventy-eight percent of the women identified as agents of conversion brought a family member to faith. For instance, Saint Pelarianus was converted by his wife. The Book of the Saints commemorates his martyrdom on the twenty-sixth of Khedar. Pelarianus and his parents were pagans, and they married him to the daughter of a rich noble who was also a Christian. They entered the marriage chamber and "as soon as she saw that he loved her dearly she began to reveal to him the faith of Christ, and he believed through her, and was baptized with Christian baptism" (Budge 1928). Kilkeya, the wife of Pelarianus, successfully converted her new husband in part because of their personal relationship. Furthermore, unlike the examples where men were the agents of conversion, these women participated in conversion in a private rather than public setting. Kilkeya introduced Pelarianus to the faith in a private, intimate setting by leveraging their close relationship through marriage.

Female family members also played an important role in two stories where men converted to another faith and were encouraged to return to Christianity. The story of Saint James "the chopped" is included on the twenty-seventh of Khedar. James served as a soldier for the son of the king of Persia. They became close friends, and James began worshiping the Persian gods and participating in Persian religious practices. When his mother, wife, and sister heard that he had abandoned Christianity for the Persian gods, they wrote him a furious letter threatening to cut ties with him if he persisted in his new faith (Budge 1928). The letter severely affected James, and he left the service of the king in order to return to Christianity. When the king found out, he tortured James by individually chopping off his fingers and toes before dividing the rest of his body into thirty-two pieces, hence his strange moniker. The threat of abandonment from the women in his family provided James with the resolve to convert back to Christianity despite the consequences. Women's words, though informal and personal, brought about his conversion.

In a similar story, Saint Dioscurus returned to Christianity after converting to Islam because of a letter from his sister. After hearing about her brother's new Muslim faith, she wrote, "I would rather that news had come to me telling me that thou hadst died a Christian ... than that this news of thee which hath reached me, telling me that thou art not dead, and that thou hast abandoned the Faith of Christ, thy God" (Budge 1928). She severed all ties with her brother, which caused him great grief, so Saint Dioscurus chose to convert back to Christianity and face martyrdom. As demonstrated by these two examples, the words of female family members exerted a great deal of influence and brought about the conversion of numerous saints in The Book of the Saints.

Wives, daughters, and sisters all appeared as agents of conversion in at least one saint's life, but the most significant familial relationship represented in the text was that of mother. Of the eighteen saints converted by a female family member, twelve of them became Christians through the efforts of their mother. In fact, The Book of the Saints credits a mother with the conversion of one of the most famous Christian saints. On the twenty-eighth of the month of Magabit, the text commemorates Saint Constantine, the first Christian emperor (Budge 1928). His mother Helena was a Christian and "she brought him up very piously ... and she sowed in his heart mercy and compassion for the Christians, but she did not dare to have him baptized with Christian baptism" out of fear of his father (Budge 1928). Following his later vision of the cross and subsequent victories, Constantine received baptism and enacted legislation favorable to Christians. Significantly, the text credits his mother Helena with introducing him to the faith and instilling in him a positive view towards Christianity. Women had considerable opportunity to convert their children through their role as mothers, yet their participation in conversion remained informal and within the private sphere.

Of the twenty-three women identified as agents of conversion, only one provides an exception to this gendered public/private distinction. On the twenty-fifth of the month of Hamle, The Book of the Saints commemorates Saint Thecla (Budge 1928). Thecla heard Paul preaching through an open window and converted, yet another example of the pattern of impersonal conversions when a man was the agent of conversion. She defied her parents to follow the teachings of Paul, and her own 
mother cried out for Thecla to be tortured as an example to other young noblewomen not to convert to Christianity. She miraculously endured the tortures and escaped, preaching the faith everywhere she went. Unlike most of the women considered thus far, Thecla taught publicly about Christianity to people with whom she had no prior relationship. Towards the end of her story, however, she returned to her own city and successfully converted both of her parents. Despite preaching and teaching publicly, the text still represented Thecla as an agent of conversion within her own family.

Taken together, these examples demonstrate how women often converted those they already knew, especially through familial relationships. Women's participation in conversion activities largely remained within the private sphere; few women represented in The Book of the Saints preached publicly like Saint Thecla. These personal relationships provided women with the opportunity to act as agents of conversion. In contrast, almost all of the men depicted as agents of conversion were either part of the ecclesiastical hierarchy or widely recognized for their teaching ability. Men participated in conversion through their public roles as preachers and teachers and often converted someone with whom they had no prior relationship. Although the text acknowledged women's ability to convert others and included them as agents of conversion nearly as often as men, the representation remained gendered. In conclusion, this paper will consider how this gendered representation in the Book of the Saints connects to larger scholarly conversations about conversion in the history of Christianity.

\section{Conclusions}

In her widely read work Christian Mission: How Christianity Became a World Religion, Dana Robert makes several key observations about women and the Christian faith. First, Christianity is predominately a women's religion with women making up the majority of active believers. Second, across all denominations, the majority of missionaries in the nineteenth and twentieth centuries were women. Yet Robert writes, "because the priests, preachers, theologians, public leaders, and famous missionary entrepreneurs are typically male, the crucial roles of women in mission remain buried in the unwritten stories of human relationships" (Robert 2009). Denied access to institutional positions throughout most of Christian history, women utilized personal interactions as a means to spread the faith. These interpersonal relationships formed the core of women's participation in the movement of the Christian religion.

Until recently, women's contributions to Christian missionary activity remained overlooked in the standard mission histories (Neill 1964). Robert and other scholars have begun to remedy this exclusion by recovering the critical activities of women on the mission field. Their research focuses on the nineteenth and twentieth centuries, when women participated as missionaries in an official capacity. This chronological limitation stems in part from a lack of source material; women do not frequently appear in traditional missionary sources for earlier time periods. In an attempt to overcome this methodological hurdle, this paper moved outside traditional sources and employed hagiography to analyze women's roles in the spread of Christianity prior to the missionary movement of the previous two centuries. As a case study, this paper examined The Book of the Saints of the Ethiopian Church and argued that the text portrayed women as agents of conversion largely through their personal relationships.

The translated nature of The Book of the Saints adds a layer of complexity when trying to ascertain what these hagiographies can communicate about medieval Ethiopian Christianity. Although most of the saints' lives were neither written nor compiled by Ethiopians, the text's incorporation into the liturgy and evidence of widespread acceptance in the number of surviving copies indicates that the stories appealed to and resonated with Ethiopian Christians. The adoption of The Book of the Saints suggests that the saints' lives aligned with the Ethiopian Christian imagination. The conversion narratives considered here show that space existed in the Ethiopian Christian imagination for women to participate in the spread of Christianity, which perhaps reflects the historical reality of women's roles in Ethiopian Christianity more broadly. According to writings attributed to a fifteenth-century Ethiopian king, Zä'ra Ya'eqob, women could not serve as priests but could become nuns (Herman 2020). 
Furthermore, the laity, both men and women, were expected to receive the same instruction in the faith. Very little information exists about women from this period, especially non-elite women, yet these hagiographies that depict women as active participants in the faith, albeit within the private sphere, were accepted as part of the Ethiopian tradition. Perhaps these stories resonated with the historical reality of women's exclusion from the ecclesiastical hierarchy while maintaining their ability to wield religious influence and authority.

In regard to conversion specifically, The Book of the Saints represented men and women as almost equally likely to be agents of conversion, but their participation remained gendered. Men were more likely to convert someone with whom they had no prior relationship, whereas women usually converted someone they already knew, often a family member. Men participated in conversion in the public arena, while women's activities remained in the private sphere. These observations about the gendered representation in conversion narratives in The Book of the Saints mirror the pattern uncovered by contemporary scholars of mission history like Robert. Although hagiography remains a difficult source for scholars to work with, it can reveal interesting points of connection and overlap with historical reality. The women represented in the text participated in conversion through human relationships rather than institutional positions, much like the female missionaries of the nineteenth and twentieth centuries, further underscoring the critical role women played in the spread of Christianity.

Funding: This research received no external funding.

Acknowledgments: An earlier version of this paper benefited from audience comments at the 2020 Winter Meeting of the American Society of Church History.

Conflicts of Interest: The author declares no conflict of interest.

\section{References}

Abir, Mordechai. 1980. Ethiopia and the Red Sea: The Rise and Decline of the Solomonic Dynasty and Muslim-European Rivalry in the Region. London: Frank Cass and Company.

Budge, E. A. Wallis. 1928. The Book of the Saints of the Ethiopian Church: [A Translation of the Ethiopic Synaxarium: Made from the Manuscripts Oriental 660 and 661 in the British Museum]. Cambridge: Cambridge Press.

Duffy, Eamon. 2012. Introduction. In The Golden Legend: Readings on the Saints. Translated by William Granger Ryan. Princeton: Princeton University Press.

Fauvelle, François-Xavier. 2020. Of Conversion and Conversation: Followers of Local Religions in Medieval Ethiopia. In A Companion to Medieval Ethiopia and Eritrea. Edited by Samantha Kelly. Leiden: Brill.

Guidi, Ignazio. 1911. The Ethiopic Senkessar. The Journal of the Royal Asiatic Society of Great Britain and Ireland 1: 739-58. [CrossRef]

Herman, Margaux. 2020. Towards a History of Women in Medieval Ethiopia. In A Companion to Medieval Ethiopia and Eritrea. Edited by Samantha Kelly. Leiden: Brill.

Horton, Robin. 1971. African Conversion. Africa: Journal of the International African Institute 41: 85-108. [CrossRef]

Jindra, Ines W. 2014. A New Model of Religious Conversion: Beyond Network Theory and Social Constructivism. Leiden: Brill.

Kaplan, Steven. 1981. Hagiographies and the History of Medieval Ethiopia. History in Africa 8: 107-23. [CrossRef] Kaplan, Steven. 1984. The Monastic Holy Man and the Christianization of Early Solomonic Ethiopia. Wiesbaden: Verlag. Kaplan, Steven. 2004. Themes and Methods in the Study of Conversion in Ethiopia: A Review Essay. Journal of Religion in Africa 34: 373-92. [CrossRef]

Mecca, Selamawit. 2006. Hagiographies of Ethiopian Female Saints: With Special Reference to 'Gädlä Krestos Sämra' and 'Gädlä Feqertä Krestos'. Journal of African Cultural Studies 18: 153-67. [CrossRef]

Mecca, Selamawit. 2009. Women in Ethiopic Hagiographies. In Proceedings of the Sixteenth International Conference of Ethiopian Studies. Edited by Svein Ege, Harald Aspen, Birhanu Teferra and Shiferaw Bekele. Trondheim: Norwegian University of Science and Technology.

Neill, Stephen. 1964. A History of Christian Mission. Baltimore: Penguin Books.

Nock, Arthur Darby. 1933. Conversion: The Old and the New in Religion from Alexander the Great to Augustine of Hippo. Oxford: Clarendon Press. 
Phillipson, David W. 2012. Foundations of an African Civilisation. Suffolk: James Currey.

Rambo, Lewis R., and Charles E. Farhadian. 2005. Conversion. In Encyclopedia of Religion, 2nd ed. Edited by Lindsay Jones. Detroit: Macmillan Reference USA, vol. 3.

Reames, Sherry L. 1985. The Legenda Aurea: A Reexamination of Its Paradoxical History. Madison: University of Wisconsin Press.

Robert, Dana. 2009. Christian Mission: How Christianity Became a World Religion. Chichester: Wiley-Blackwell.

Rossini, Conti. 1937. L'agiografia etiopica e gli atti del santo Yafqeranna Egzi (secolo XIV). Atti dei reale Istituto Veneto 96: 403-12.

Saint-Laurent, Jeanne-Nicole Mellon. 2015. Missionary Stories and the Formation of the Syriac Churches. Berkley: University of California Press.

Sterk, Andrea. 2010a. Mission from Below: Captive Women and Conversion on the East Roman Frontiers. Church History 79: 1-39. [CrossRef]

Sterk, Andrea. 2010b. 'Representing' Mission from Below: Historians as Interpreters and Agents of Christianization. Church History 79: 271-304. [CrossRef]

Swanson, Robert N. 1995. Religion and Devotion in Europe, c. 1215-c. 1515. Cambridge: Cambridge University Press. Tamrat, Tadesse. 1972. Church and State in Ethiopia 1270-1527. Oxford: Clarendon Press.

(C) 2020 by the author. Licensee MDPI, Basel, Switzerland. This article is an open access article distributed under the terms and conditions of the Creative Commons Attribution (CC BY) license (http://creativecommons.org/licenses/by/4.0/). 


\title{
The "Conversion" of Anthony Obinna to Mormonism: Elective Affinities, Socio-Economic Factors, and Religious Change in Postcolonial Southeastern Nigeria
}

\author{
David Dmitri Hurlbut \\ Department of History, Boston University, Boston, MA 02215, USA; dhurlbut@bu.edu
}

Received: 26 May 2020; Accepted: 10 July 2020; Published: 15 July 2020

\begin{abstract}
This article analyzes the "conversion" of Anthony Uzodimma Obinna, an Igbo schoolteacher from the town of Aboh Mbaise in Imo State, and his extended family to Mormonism in southeastern Nigeria between the 1960s and the 1980s, from a historical perspective. I argue that the transition of Anthony Obinna and his family away from Catholicism to Mormonism can be explained by both the elective affinities that existed between Mormonism and indigenous Igbo culture, and socio-economic factors as well. This article bases its conclusions on a close reading of oral histories, personal papers, and correspondence housed at the LDS Church History Library in Salt Lake City, Utah and L. Tom Perry Special Collections at Harold B. Lee Library, Brigham Young University in Provo, Utah.
\end{abstract}

Keywords: Mormonism; The Church of Jesus Christ of Latter-day Saints; Anthony Obinna; religious conversion; southeastern Nigeria

\section{Introduction: The Official Story of Anthony Obinna}

This article analyzes the "conversion" of Anthony Uzodimma Obinna, an Igbo schoolteacher from the town of Aboh Mbaise in Imo State in the southeastern part of Nigeria, and his extended family to the Church of Jesus Christ of Latter-day Saints (LDS Church) between the 1960s and the 1980s. ${ }^{1}$ Offering a social explanation of religious change that complicates the official narratives of Anthony Obinna's "conversion," I argue that the movement of Anthony Obinna and his family away from Catholicism to Mormonism can be explained by both the elective affinities that existed between Mormonism and indigenous Igbo culture, and socio-economic factors as well. This article bases its conclusions on a close reading of oral histories, personal papers, and correspondence housed at the LDS Church History Library in Salt Lake City, Utah and L. Tom Perry Special Collections at the Harold B. Lee Library, Brigham Young University in Provo, Utah.

According to official narratives, Obinna's "conversion" hinged on a series of revelatory dreams that he experienced between 1965 and $1967 .^{2}$ The story of Obinna's dreams have been recounted in various levels of detail in official church publications, Obinna's autobiography and oral histories,

1 On the expansion of Mormonism in West Africa, see (Allen 1991; Hurlbut 2018, 2019a, 2020; Stevenson 2014, 2015).

2 For references to Nigerian engagement with LDS Church during the 1940s and the 1950s, see "Interview Between Dale LeBaron and Bassey Daniel Udoh, Ikot Ebo, State of Akwa Ibom, Nigeria, 28 May 1988," p. 4, Box 12, Folder 9, MSS 1937, African Oral History Project, L. Tom Perry Special Collections, Harold B. Lee Library, Brigham Young University, Provo, Utah (hereafter LTPSC); OH 692, LaMar S. Williams Interview: Salt Lake City, Utah, 1981, pp. 2, 51, Church History Library, Church of Jesus Christ of Latter-day Saints, Salt Lake City, Utah (hereafter CHL); Williams, Letter to Emelumadu, 23 July 1963, Box 1, Folder 1, MSS 21299, Edwin Q. Cannon Papers, 1963-1986, CHL. See also (Allen 1991, p. 212; Hurlbut 2018, p. 1; Hurlbut 2015, p. 1). 
and the following reconstruction is a composite of all these various accounts (Obinna 1980). ${ }^{3}$ Obinna reported that he had his first revelatory dream on the same day that he was transferred to teach at a school in Itu in the Calabar Province of Nigeria's Eastern Region, in November $1965 .{ }^{4}$ In this dream, a tall man in white shorts who carried both a walking stick in his right hand and a pillow on top of his head appeared, walked up to Obinna, and asked him whether he was familiar with the teachings of Christianity and the story of Christian and Christiana as recounted in John Bunyan's novel Pilgrim's Progress (Obinna 1980). ${ }^{5}$ Obinna responded to the unnamed man that he was familiar with their story, but that he had forgotten the details since it had been such a long time since he had read the novel (Obinna 1980). ${ }^{6}$ The man with the walking stick then told Obinna to re-read the novel, and knocked the pillow onto Obinna's head. Once he had transferred the pillow to Obinna's head, a crucified Jesus Christ appeared in the dream and the unnamed man disappeared. ${ }^{7}$ When Obinna woke up the following morning, he went to his personal library and removed Pilgrim's Progress from the shelf. Obinna opened up the book to a random page where, he stated, he read the words: "We are living in the city of destruction. I must seek for the celestial city," a statement which does not appear anywhere in Bunyan's book. ${ }^{8}$ Obinna asked friends and family members about this passage, but they could not decipher the meaning of the words he read. ${ }^{9}$ However, a few months later, Obinna stated that the unnamed man appeared in his dreams again, and he took Obinna to the "most beautiful building" and showed him the interior of the building, and told him that "this is a holy place, a place of worship. Only selected people go in there. It is not meant for everybody." ${ }^{10}$ After seeing the beautiful building in his dreams, Obinna stood among "priests" in his dreams each night. ${ }^{11}$ A couple of years later, during the Nigerian Civil War, Obinna picked up an offprint of an old edition of Reader's Digest that had somehow made its way into southeastern Nigeria, and discovered an article on the Mormons, titled "the March of the Mormons," which contained an image of the LDS Temple-the building that Obinna said that he had seen in his dreams (Obinna 1980). ${ }^{12}$ Once the Nigerian Civil War ended and the blockade was lifted, Obinna began a trans-Atlantic correspondence with the church, and he repeatedly asked for church literature and missionaries to be sent to his community in southeastern

3 See, for instance, "Interview Between Dale LeBaron and Anthony U. Obinna, Aboh Mbaise, Imo State, Nigeria, 4 June 1988," pp. 4-6, 14-18, Box 11, Folder 3, African Oral History Project, LTPSC; "Interview Between Dale LeBaron and Raymond Obinna, Aboh Mbaise, Imo State, Nigeria, 4 June 1988," pp. 3-4, Box 11, Folder 6, African Oral History Project, LTPSC; "Video of Anthony and Fidelia Obinna: Their Trip to the Logan Temple and Surrounding Events," pp. 12-13, Box 11, Folder 2, African Oral History Project, LTPSC. Anthony Obinna, "NNo Toil Nor Labour Fear, We Shall Not Shun the Fight': The Auto Biography of Anthony Uzodimma Obinna, Box 1, Folder 10, Edwin Q. Cannon Papers, CHL.

4 "Interview Between Dale LeBaron and Anthony U. Obinna, Aboh Mbaise, Imo State, Nigeria, 4 June 1988," p. 4, Box 11, Folder 3, African Oral History Project, LTPSC; "Interview Between Dale LeBaron and Fidelia Obinna, Aboh Mbaise, Imo State, Nigeria, 4 June 1988," p. 1, Box 11, Folder 4, African Oral History Project, LTPSC; Anthony Obinna, "No Toil Nor Labour Fear, We Shall Not Shun the Fight," Box 1, Folder 10, Edwin Q. Cannon Papers, CHL.

5 Interview Between Dale LeBaron and Anthony U. Obinna, Aboh Mbaise, Imo State, Nigeria, 4 June 1988," p. 4, Box 11, Folder 3, African Oral History Project, LTPSC; "No Toil Nor Labour Fear, We Shall Not Shun the Fight," p. 2, Box 1, Folder 10, Edwin Q. Cannon Papers, CHL.

6 Interview Between Dale LeBaron and Anthony U. Obinna, Aboh Mbaise, Imo State, Nigeria, 4 June 1988," p. 5, Box 11, Folder 3, African Oral History Project, LTPSC; Anthony Obinna, "No Toil Nor Labour Fear, We Shall Not Shun the Fight," p. 2, Box 1, Folder 10, Edwin Q. Cannon Papers, CHL.

7 “Interview Between Dale LeBaron and Anthony U. Obinna, Aboh Mbaise, Imo State, Nigeria, 4 June 1988," p. 14, Box 11, Folder 3, African Oral History Project, LTPSC; Anthony Obinna, "No Toil Nor Labour Fear, We Shall Not Shun the Fight," p. 2, Box 1, Folder 10, Edwin Q. Cannon Papers, CHL.

8 "Interview Between Dale LeBaron and Anthony U. Obinna, Aboh Mbaise, Imo State, Nigeria, 4 June 1988," p. 4, Box 11, Folder 3, African Oral History Project, LTPSC. This quote could be a paraphrase of a recurring statement from Christian that occurs at multiple points throughout the book: "I am come from the City of Destruction, and am going to Mount Zion" (Bunyan 1678, p. 14).

9 "Interview Between Dale LeBaron and Anthony U. Obinna, Aboh Mbaise, Imo State, Nigeria, 4 June 1988," p. 5, Box 11, Folder 3, African Oral History Project, LTPSC.

10 Ibid., p. 6.

11 Anthony Obinna, "No Toil Nor Labour Fear, We Shall Not Shun the Fight," p. 2, Box 1, Folder 10, Edwin Q. Cannon Papers, CHL.

12 Ibid., p. 3; "Interview Between Dale LeBaron and Anthony U. Obinna, Aboh Mbaise, Imo State, Nigeria, 4 June 1988," p. 5 , Box 11, Folder 3, African Oral History Project, LTPSC. 
Nigeria (LeBaron 1996, p. 85). He and his family practiced their new faith on their own terms using the literature they received from their correspondents in Salt Lake City, until President Kimball had his revelation on the priesthood in 1978, and sent LDS missionaries Edwin Q. Cannon and Rendell N. Mabey to establish officially the church in Nigeria. They baptized Obinna and many of his family members on November 21,1978, and then called many of them to serve as leaders in the newly formed Aboh Branch (Mabey and Allred 1984, p. 47). ${ }^{13}$

While this account of Obinna's journey to Mormonism roots his decision to join the LDS Church in the dreams he claimed to experience, and this story continues to be promoted by faithful Latter-day Saints (e.g., Kline 2019), the narrative is problematic from a historical perspective for at least four reasons. First, the various accounts on which I have based the above reconstruction of Obinna's "conversion" were all recorded in the 1980s-years after Obinna had officially joined the LDS Church-and so they cannot be considered reliable accounts of his "conversion." To the best of my knowledge, no contemporaneous accounts of Obinna's dream experiences survive. Second, all existing records of his dreams were produced for the official church. Obinna published his autobiography in Ensign, an LDS periodical, and E. Dale LeBaron, a former president of the LDS South Africa Mission, conducted the oral histories which contain accounts of Obinna's dreams as part of an African oral history program that he spearheaded for the LDS Church during the 1980s. ${ }^{14}$ Thus, it is very possible that Obinna sought to describe his "conversion" to Mormonism in a manner that would be palatable to church officials. Third, Obina's dreams include details about LDS practices that Obinna could not have known before becoming a Latter-day Saint. Obinna, for example, could not have known that LDS temples were restricted to those who have temple recommends or certification, or that those who enter the temple to perform ordinances wear "white, complete white" for every ceremony. ${ }^{15}$ Fourth, the dreams contain some Mormon tropes. Obinna, for instance, was guided by a messenger in his dreams just as Joseph Smith was guided by Moroni in his early visions (Taylor 2019, p. 48). Given these issues with the official narrative of Anthony Obinna's "conversion," I provide an alternative social explanation that offers another window onto these historical events and archival sources.

\section{Elective Affinities and Religious Change in Southeastern Nigeria}

Max Weber popularized the term "elective affinity" in his sociological works on religion. Although Weber never defined the term in his published works, the Marxist sociologist Michael Löwy has argued that an elective affinity "is a process through which two cultural forms, who have certain analogies, intimate kinships or meaning affinities, enter in a relationship of reciprocal attraction and influence" (Löwy 2014, p. 103). The concept of an elective affinity, as defined by Löwy, is useful for explaining why Anthony Obinna was drawn to the LDS Church. An analysis of archival evidence suggests that Anthony Obinna joined the LDS Church because of elective affinities that existed between Mormonism and indigenous Igbo culture, including an attraction between (1) indigenous and Mormon practices of dreaming and prophecy, and between (2) indigenous cultural associations and the LDS Church.

\subsection{Dreaming and Prophecy in Southeastern Nigeria}

Many of Obinna's family members and acquaintances took his experiences seriously. After he experienced his first dream, Obinna reported that he went to his priest and asked him "how Christ could appear to somebody in a dream." 16 The priest told him that if it were a legitimate vision, he would find out in time: "if it is anything, that it must come to be."17 Obinna's wife, Fidelia, recalled that

\footnotetext{
3 "Imo State District, Aboh Branch Priesthood Ordinations," Box 1, Folder 4, Edwin Q. Cannon Papers, CHL.

On E. Dale LeBaron's African oral history program, see (Hurlbut 2019b).

15 “Interview Between Dale LeBaron and Anthony U. Obinna, Aboh Mbaise, Imo State, Nigeria, 4 June 1988," p. 15, Box 11, Folder 3, African Oral History Project, LTPSC.

16 Ibid., p. 5.

17 Ibid., p. 5.
} 
when Obinna began to experience his dreams, she "believed, and followed him." 18 When Raymond, Anthony's brother, learned about the dreams, he similarly told Anthony that "[w]e will follow you and do the same thing you are doing." ${ }^{19}$ Not everyone proved to be as accepting as Obinna's family members. Those acquaintances who doubted the authenticity of Obinna's visions, however, did so because they thought that Obinna was simply looking for an excuse to join a church that would "yield him money" to improve his socio-economic status, not because they doubted that some Nigerians had the gifts of prophecy. ${ }^{20}$

These reactions to Obinna's experiences should not surprise those who are familiar with the religious history of southeastern Nigeria. While Anthony Obinna, his family members and the church leaders frequently switched between describing Obinna's experiences as "dreams," "visions," "prophecy," and "revelation" in their interviews, both dreaming and prophesy have a historical precedent in southeastern Nigeria. ${ }^{21}$ Archaeologist Ray (1992) has concluded that dreaming has played a strategic political/religious function since at least the turn of the 20th century. Drawing on the interviews of colonial anthropologists with local kings and candidates for kingships, Ray observed that rival aspirants for "offices ranging from that of the periodic bearer of the 'medicine' bundle (Onumonu) which constitutes a manifestation of a local deity, through the chief earth-priest of certain Igbo towns, to the sacred king of the Umueri Igbo", used dreams to legitimate their claims between the early 1900s and 1990s (Ray 1992, p. 55). In these formulaic dreams, the dreamer is visited by a messenger, usually "the previous incumbent of the office or a manifestation of the spirit to the service of whom the office is devoted," who places "the symbols of the office in the hands of the dreamer" (Ray 1992, p. 67). The similarities between Obinna's own dreams and context and those analyzed by Ray are striking. Not only did Obinna's dreams contain important Mormon symbols, but he was also visited by someone representing Jesus Christ. In addition, these dreams served as a supernatural justification for Obinna's decision to leave the Catholic Church and found his own "Mormon" church. ${ }^{22}$

Prophecy has also played a central role in the daily life of southeastern Nigeria, as far back as scholars can document Nigerian history, in the form of oracles (Manfredi 2014, 2015a, 2015b, 2015c, 2016, 2017). In the precolonial period, dozens of oracles performed important social, political and legal functions in the southeast. These oracles were not prophetic in the common sense of the word, but rather these oracles spoke with "ostensive detachment", by channeling the voice of the ancestors who laid down what worked in the past in order to guide human action in the future (Boyer 2020). The "most influential and widespread" oracle in precolonial Igboland was the "Long Juju" oracle of the Aro Chukwu (Ottenberg 1958, p. 299). The agents of the "Long Juju" frequently resolved disputes and cases involving witchcraft, theft, murder, sorcery, weak crop yields, illness and infertility (Ottenberg 1958, pp. 302-304). While the "Long Juju" oracle was the most prominent oracle in southeastern Nigeria, it was not the only oracle in the region. Indeed, anthropologist Victor Uchendu has observed

18 "Interview Between Dale LeBaron and Fidelia Obinna, Aboh Mbaise, Imo State, Nigeria, 4 June 1988," p. 1, Box 11, Folder 4, African Oral History Project, LTPSC. See also "Interview Between Dale LeBaron and Stella Obinna, Aboh Mbaise, Imo State, Nigeria, 4 June 1988," p. 1, Box 11, Folder 7, African Oral History Project, LTPSC.

19 "Interview Between Dale LeBaron and Raymond Obinna, Aboh Mbaise, Imo State, Nigeria, 4 June 1988," pp. 3-4, Box 11, Folder 6, African Oral History Project, LTPSC.

20 "Interview Between Dale LeBaron and Stella Obinna, Aboh Mbaise, Imo State, Nigeria, 4 June 1988," p. 3, Box 11, Folder 7 , African Oral History Project, LTPSC. See also "Interview Between Dale LeBaron and Anthony U. Obinna, Aboh Mbaise, Imo State, Nigeria, 4 June 1988," p. 23, Box 11, Folder 3, African Oral History Project, LTPSC.

21 "Video of Anthony and Fidelia Obinna: Their Trip to the Logan Temple and Surrounding Events," p. 12, Box 11, Folder 2, African Oral History Project, LTPSC; Interview "Between Dale LeBaron and Anthony U. Obinna, Aboh Mbaise, Imo State, Nigeria, 4 June 1988," Box 11, Folder 3, African Oral History Project, LTPSC; "Interview Between Dale LeBaron and Fidelia Obinna, Aboh Mbaise, Imo State, Nigeria, 4 June 1988," p. 1, Box 11, Folder 4, African Oral History Project, LTPSC; “Interview Betwee Dale LeBaron and Francis Obinna, Aboh Mbiase, Imo State, Nigeria, 4 June 1988, pp. 1, 5, 6, Box 11, Folder 5, African Oral History Project, LTPSC; “Interview Between Dale LeBaron and Raymond Obinna, Aboh Mbaise, Imo State, Nigeria, 4 June 1988," p. 3, Box 11, Folder 6, African Oral History Project, LTPSC; "Interview Between Dale LeBaron and Stella Obinna, Aboh Mbaise, Imo State, Nigeria, 4 June 1988," p. 1, Box 11, Folder 7, African Oral History Project, LTPSC.

22 Latter-day Saints also believe that divine revelation can be communicated to humans through dreams. See, for instance, (Jenkins 2011; Woodger et al. 2019). 
that the number of oracles in Igboland "is enormous" (Uchendu 1965, p. 101). During the colonial period, oracles were also documented at Awka, Umunoha, Awgu, Ozuzu Obunka and Eha-Emufu, Enugu and Ezira (Forde and Jones 1950, p. 26; Ottenberg 1958, p. 308). While the British made their best effort to destroy indigenous oracles, with varying levels of success, following the establishment of colonial rule (Afigbo 1971, pp. 8, 13; Ellis 2008, p. 449; Kalu 1977, p. 79; Ottenberg 1958, p. 308), some oracles have persisted to the present day. The most prominent contemporary oracle is the Okija shrine in Anambra State, where Theodore Orji, the former governor of Abia State, famously took an oath in his underwear to repay his political godfather from state coffers (Ellis 2008, p. 447).

While the importance of oracles in southeastern Nigeria diminished following the establishment of colonialism, prophetic churches multiplied throughout the region over the course of the 20th century. ${ }^{23}$ The first Christian prophetic movement in the southeast, the Garrick Braide movement, emerged in 1915 after Bishop James Johnson forced the catechist Garrick Braide out of the Niger Delta Pastorate Church, an indigenous Anglican offshoot, because Johnson believed that Braide's status as a religious prophet threatened to undermine the authority of the church, and he objected to the fact that Braide practiced faith-healing (Ludwig 1993, p. 296). The late 1920s similarly saw the emergence of a Sprit movement in the Ibibio-speaking region that practiced "visioning, prophecy, dreaming and speaking in tongues" (Pratten 2007, p. 54), which eventually congregated around the leadership of Michael Ukpong Udo, Richneal Ekit and Akpan Udofia at the Oberri Okaime Church (Abasiattai 1989; Jones 1989; Pratten 2007). Today, the Oberri Okaime Church remains famous for Medefaidrin, the sacred Ibibio script allegedly revealed to Ukpong and Udofia by the Holy Spirit which they used to reduce the Ibibio language to writing (Adams 1947; Hau 1961). In historical hindsight, the emergence of indigenous movements in the region, dedicated to showcasing the powers of the Spirit, was probably inevitable, as most Nigerians in the early 20th century belonged to Protestant churches that taught their members to interpret the Bible for themselves (Moller 1968, p. 232). Between the 1930s and 1960s, dozens of local prophets continued to establish churches, such as the Spiritual Church of the Lord (Amadi 1982), the Brotherhood of the Cross and Star (Amadi 1982; Mbon 1986a; Mbon 1986b; Mbon 1992) and the Eternal Sacred Order of Cherubim and Serafim (Moller 1968) in the southeast, outside of the control of colonial mission churches. Dozens of Pentecostal prayer houses also blossomed throughout the region in the late 1960s, as the peoples of southeastern Nigeria struggled to cope with the devastating effects of the Nigerian Civil War on their daily lives (Burgess 2008; Daly 2017; Nwaka 2013). The appeal of these churches to Nigerians is obvious. Local prophets provided Nigerians with accessible solutions (i.e., prayer and ritual bodily discipline) to everyday problems, frequently at no cost to the person seeking the services of the prophet (Amadi 1982, pp. 28-31; Mbon 1986a, p. 56).

The emergence of an Igbo schoolteacher as the prophet of a small indigenous church in the early 1970s fits neatly within the longer history of prophetic revival movements in southeastern Nigeria. While the sources agree that Obinna received his first vision in 1965, the rest of his visions occurred sometime between 1967 and 1971, during the Nigerian Civil War. ${ }^{24}$ It does not seem like too much of a leap to speculate that Obinna's later visionary experiences were a direct response to the "apocalypse" that many Igbo men and women experienced during the catastrophic war, and that Obinna perceived Mormonism as an alternative and more effective way to remedy the insecurity he experienced during the blockade, as opposed to the other religious movements present in southeastern Nigeria. After receiving what he believed were legitimate visions, it was necessary for Obinna to abandon the Catholic Church, since the historical mission churches did not endorse the practice of prophecy. Like other local prophets who came before him, Obinna established his new church on his own property (Amadi 1982, p. 217; Mbon 1986a, p. 58). Here, he and his followers, composed mostly

23 For a bibliography of secondary literature on the history of Christianity in Nigeria, see (Hurlbut 2017).

24 Raymond Obinna, [Untitled Document], Folder 1, MS 26912, Obinna Family Papers, 1984-2006, CHL. Albert Obinna, Anthony's brother, also stated in a recent interview that Anthony's dreams began to reoccur during the Nigerian Civil War (Kline 2019). 
of his family members, worshipped with LDS literature that their interlocutors at church headquarters in Salt Lake City mailed to them, from 1971 until October 1978, when the LDS Church officially opened Nigeria to missionary work following President Kimball's revelation on the priesthood (LDS Church 2013, Official Declaration 2). ${ }^{25}$ In the LDS Church, Anthony Obinna and his family members found an international mission church that did not shun the gifts of prophecy, but rather was led by a "prophet, seer, and revelator", and his apostles (LDS Church 2013, Section 21: 1; see also Jenkins 2009, p. 11). The LDS Church was a prophetic Western mission church that provided Obinna and his followers with access to the religious practices that many Nigerians had actively embraced for decades, but in the form of a religious institution that possessed greater "Christian respectability" than they could find in any indigenous Pentecostal churches or prayer houses (Daly 2017). ${ }^{26}$ In short, Nigerian engagement with Mormonism can be viewed in part as a result of a shared affinity for dreaming and prophecy in both Mormon and Igbo culture.

\subsection{Purchasing Culture and Social Prestige in Southeastern Nigeria}

Anthony Obinna's acquisition of Mormonism structurally mirrored how the peoples of southeastern Nigeria had acquired and diffused dozens of indigenous cultural associations since at least the arrival of the Europeans in the 1600s. Anthropologist Ute Röschenthaler has demonstrated that cultural associations could be "disseminated [in southeastern Nigeria] by complex transactions of knowledge and use rights in the intellectual property" (Röschenthaler 2004, p. 242). This is a process that Röschenthaler describes as "purchasing culture" in her 2011 monograph. These institutions were exchanged among regional communities in order to solve specific problems, such as combatting witchcraft or protecting goats from predatory leopards, to build and strengthen relationships with neighboring communities, to forge trade alliances, and to establish spheres of influence during the era of the slave trade and colonialism (Röschenthaler 2004, pp. 242-43, 64; see also Röschenthaler 2011, chp. 4). To acquire an association, community members had to be initiated into the association they were "purchasing." This required, as Röschenthaler has observed, learning "the performance of the society's dances and songs, how to fill the posts, initiate new members, employ them for its aims, as well as to manipulate the objects and supply them with power or agency-in short the knowledge necessary to operate the entire association successfully" (Röschenthaler 2004, p. 266; see also Röschenthaler 2011, chp. 7). Once a community had done this, it earned the right to use and sell the association to other communities for its own gain.

The history of Mormonism, which is, at its core, an initiatory cultural association, in Aboh Mbaise conforms to the pattern of associational expansion described in Röschenthaler's research. The evidence suggests that Obinna (and other Nigerians) may have perceived Mormonism to be a convenient way to forge a relationship with America in the dynamic postcolonial environment. When Nigerians achieved their political independence, they turned towards the LDS Church (and other American churches) with hope for what the future might bring. In the post-Second World War environment, there was much to be gained from allying oneself with the United States and its institutions. E.I. Okpon, a member of the unofficial "Church of Jesus of Christ of Latter-day Saints" in Uyo, a town in the Efik-speaking region of southeastern Nigeria, wrote to LaMar S. Williams (an employee of the LDS Church's Missionary Department who had been tasked with corresponding with Nigerians) in October that "At this age when Nigeria is attaining Independence, we hope to make it a blessed country-here, we pray for true

25 "Interview Between Dale LeBaron and Anthony U. Obinna, Aboh Mbaise, Imo State, Nigeria, 4 June 1988," p. 9, Box 11, Folder 3, African Oral History Project, LTPSC; "Interview Between Dale LeBaron and Raymond Obinna, Aboh Mbaise, Imo State, Nigeria, 4 June 1988," p. 4, Box 11, Folder 6, African Oral History Project, LTPSC. See also "Interview Between Dale LeBaron and Stella Obinna, Aboh Mbaise, Imo State, Nigeria, 4 June 1988," p. 1, Box 11, Folder 7, African Oral History Project, LTPSC.

26 In his oral history, Raymond Obinna, Anthony Obinna's brother, also suggested that he experienced visions and had the ability to heal people through prayer ("Interview Between Dale LeBaron and Raymond Obinna, Aboh Mbaise, Imo State, Nigeria, 4 June 1988," pp. 8-9, Box 11, Folder 6, African Oral History Project, LTPSC). 
religion." ${ }^{27}$ Williams heard similar comments in 1962: "As a young Independent country our spiritual growth can in no way take a secondary place viz a viz the yearnings for economic, social and mental developments." 28 Anthony Obinna expressed a similar sentiment when he wrote to the Quorum of the Twelve Apostles on September 28, 1978 and begged the Quorum to establish officially the church in Nigeria: "[t]his church if it is established in Nigeria will work wonders." 29 Just as Nigerians bought and sold indigenous cultural agencies as a way to cope with the social transformations that accompanied the trans-Atlantic slave trade and the onset of colonialism, Obinna adapted this indigenous survival strategy to the postcolonial and post-Nigerian Civil War context, by appealing to the LDS Church for affiliation and support.

In her monograph, Röschenthaler shows that cultural associations and their positions could be owned by individual families. Between 1971 and 1978, Obinna led the unofficial LDS church to the best of his ability using the LDS literature that LDS missionaries, like LaMar Williams, sent to him, and the Obinna family established an intellectual monopoly on Mormon faith in Aboh Mbaise. ${ }^{30}$ The initial members the unofficial church were Obinna, his wife and his four brothers, and the church was colloquially known throughout the village as "Obinna's Church." When the Aboh Branch was officially organized on 21 November 1978, LDS missionaries Rendell Mabey and Edwin Cannon called Obinnas to fill all of the leadership positions in the branch. ${ }^{31}$ Mabey and Cannon called Anthony Obinna to serve as the branch president; Fidelia as relief society president; Francis as Anthony's first counselor; and Raymond as Anthony's second counselor. ${ }^{32}$ By calling Anthony and Fidelia to serve as presidents, they unknowing acceded to the tradition of filling familial associational positions with "the eldest male or female member" (Röschenthaler 2011, p. 404). When Anthony Obinna was released from the branch presidency in 1983, Raymond Obinna, the eldest Obinna after Anthony, took up the position and served as branch president until March 1990, which continued the local tradition of giving associational positions to the eldest members of the family. ${ }^{33}$

Röschenthaler indicates in her monograph that "acquiring membership in associations contributed to the status of an individual in his or her village" (Röschenthaler 2011, p. 403). The Obinnas approached their acquisition of Mormonism with this knowledge in mind. When Raymond, for instance, heard about Anthony's dream, he told Anthony that "this will be a good dream for our family." ${ }^{34}$ Over the long term, the acquisition of Mormonism certainly bestowed social prestige on the Obinnas within in the Latter-day Saint community. In 1988, for instance, Francis Obinna, Anthony's brother, referred to his brother as "the founder of the Church of Jesus Christ of Latter-day Saints in West Africa." 35 The preface to Obinna's brief autobiography, published in the LDS periodical Ensign the same year, referred to Anthony Obinna and his wife, Fidelia, as "the first black members of the Church in West Africa" (Obinna 1980). ${ }^{36}$ In a welcome address for Gordon Hinckley, the 15th president of the LDS Church, during his visit to

27 Okpon, Letter to Williams, 12 October 1960, Folder 2, LaMar S. Williams Papers, CHL.

28 "Welcome Address Presented to Elder Williams and Apostle Tanner of the Church of Jesus Christ of Latter Day Saints Salt Lake City Utah on the Occasion of Their Second Missionary Journey to the Group at Aba, Eastern Nigeria, December 1962," Folder 8, LaMar S. Williams Papers, CHL.

29 Obinna, Letter to the Council of Twelve, 28 September 1978, Box 1, Folder 1, Edwin Q. Cannon Papers, CHL.

30 Ibid.

31 "Imo State District, Aboh Branch Priesthood Ordinations," Box 1, Folder 4, Edwin Q. Cannon Papers, CHL; “Interview Between Dale LeBaron and Anthony U. Obinna, Aboh Mbaise, Imo State, Nigeria, 4 June 1988," p. 32, Box 11, Folder 3, African Oral History Project, LTPSC.

32 Raymond Obinna, [Untitled Document], Folder 1, Obinna Family Papers, CHL

33 Ibid.; "A Short Note to the African West Area President (President and Sister Snow) By Elder Raymond I. Obinna on His First Visit to the Obinna Family on the 7th of Sept. 2005," Folder 1, Obinna Family Papers, CHL.

34 Raymond Obinna, [Untitled Document], Folder 1, Obinna Family Papers, CHL.

35 "Interview Between Dale LeBaron and Francis Obinna, Aboh Mbaise, Imo State, Nigeria, 4 June 1988," p. 1, Box 11, Folder 5, African Oral History Project, LTPSC.

36 The LDS Church has bestowed the status of "first member" of the church in West Africa on Anthony Obinna, because he was technically the first Nigerian to be baptized into the LDS Church in Nigeria (Mabey and Allred 1984). The title is a misnomer, however. Many Nigerians had embraced the teachings of the LDS Church and organized unofficial Mormon congregations long before Obinna came across the article in Reader's Digest. 
southeastern Nigeria for the dedication of the temple in Aba, Raymond, Francis, Vincent, and Albert Obinna referred to the Obinna family as "the pioneer members of the church in Nigeria." ${ }^{\prime 37}$ Today, it is certainly impossible to read about the global history of the LDS Church without the appearance of the Obinna name (e.g., Claremont Graduate University 2019; Stevenson 2014).

The Obinna family's embrace of Mormonism did not just garner them a special status within the global Mormon community; it also bestowed social prestige on them within the broader Igbo community of Imo State. In the early 1980s, the Obinnas drew on their transnational Mormon network to establish "small scale experimental farms" in Aboh Mbaise, where "families are taught modern agricultural methods," such as soil development using fertilizers tailored to the soil's specific chemical composition. ${ }^{38}$ The farm attracted the attention of Ike Nwachukwu, the military governor of Imo State, who paid a visit on 3 July 1984 as part of a government effort to "encourage organizations and private individuals that embark upon meaningful agricultural ventures to assist the government realise its objective in this direction. ${ }^{\prime 39}$ While it is unclear from archival documentation whether or not the LDS farm at Aboh Mbaise was ultimately a success, the visit of Nwachukwu nevertheless burnished the reputation and social prestige of the Obinnas and their congregation, who he "commended for their effort and urged them not to relent." 40

The creation of an experimental farm highlights how the Obinnas attempted to use Mormonism to provide solutions to everyday problems in postcolonial Nigeria, just as Nigerians, for example, had historically purchased the cult agency Obasinjom to counteract witchcraft (Röschenthaler 2004, p. 242). The Obinnas tried to use their affiliation with the LDS Church to make unproductive farms productive. This was not the only local problem that the Obinnas endeavored to use Mormonism to solve. Archival records also indicate that Obinna's congregation wanted to improve medical services in southeastern Nigeria. The Nigerian Statesman, for instance, reported on 9 June 1984 that LDS adherents would "embark upon health care delivery projects in the country." ${ }^{11}$ By 19 July 1984, it appears that the Aboh Mbaise Branch had received approval from the local government to open up a health clinic in Enyiogugu. ${ }^{42}$ However, it does not seem that this local healthcare endeavor was ever a major success, because, on 7 September 2005, Raymond Obinna, Francis Obinna and Albert Obinna asked the President of the West Africa Mission for "a cottage hospital to remedy the health situation of our people, which is a very vital problem within us." ${ }^{\prime 3}$ The problems that afflicted southeastern Nigerian communities following their political independence were the same problems that confronted these communities at the turn of the 21st century, and Nigerians still saw "purchasable" initiatory cultural organizations as the one of the most effective ways to address these everyday problems.

"The greatest aspiration" of the peoples of southeastern Nigeria, Röschenthaler has argued, "was to become the chief of one's own Ekpe" (Röschenthaler 2011, p. 406), the predominant initiatory society

37 "A Welcome Address Presented by the Obinnas' Family The Pioneer Members of the Church in Nigeria to the Prophet President Gordon B. Hinckley on His Official Visit to Nigeria for the Dedication of Aba Nigeria Temple," Folder 1, Obinna Family Papers, CHL.

38 "A Welcome Address to the Military Governor of Imo State Brigadier Ike Nwachukwu on the Occasion of his visit to Umuelem Enyiogugu Experimental Farm of the Church of Jesus Christ of Latter Day Saints in Nigeria," Folder 1, Obinna Family Papers, CHL. See also Emeka Ohaneche, "Religious Sect to Embark on Agric, Health-Care Delivery," Nigerian Statesman, 9 June 1984, 12, Folder 1, Obinna Family Papers, CHL: "A small experimental farm has also been started hear the Aboh Mbaise building to train famers in that area in more effective farming methods."

39 "A Welcome Address to the Military Governor of Imo State Brigadier Ike Nwachukwu on the Occasion of his visit to Umuelem Enyiogugu Experimental Farm of the Church of Jesus Christ of Latter Day Saints in Nigeria," Folder 1, Obinna Family Papers, CHL; Njoku, Letter to Brooks, 8 June 1974, Folder 1, Obinna Family Papers, CHL; Obinna, Letter to [?], 25 June 1984, Folder 1, Obinna Family Papers, CHL.

40 "Gov Visits Private Farm," Folder 1, Obinna Family Papers, CHL.

41 Emeka Ohaneche, "Religious Sect to Embark on Agric, Health-Care Delivery," Nigerian Statesman, 9 June 1984, 12, Folder 1, Obinna Family Papers, CHL.

42 "An Address Presented to the Sole Administrator, Aboh-Mbaise Local Government by the People of Enyiogugu on Thursday, 9 July 1984 at Enyiogugu Central School," Folder 1, Obinna Family Papers, CHL.

43 Raymond Obinna, Francis Obinna, and Albert Obinna, "A Welcome Address to the Area West Africa President (President and Sister Snow) by the Obinna Family," 7 September 2005, Folder 1, Obinna Family Papers, CHL. 
in southeastern Nigeria. When Anthony Obinna's acquisition of Mormonism is viewed against the Ekpe precedent, the expansion of Mormonism in the southeast conforms to a generalized, centuries-old pattern, by which exotic and prestigious ritual goods have diffused throughout the region. In short, this section has shown that Mormonism expanded in the Ekpe areas not by coincidence, but rather due to structural affinities.

\section{Socio-Economic Factors and Religious Change in Southeastern Nigeria}

Historians have documented that the peoples of southeastern Nigeria failed to reap any rewards from their "incorporation into the new world economy" following the establishment of colonialism (Ifeka-Moller 1974, pp. 61, 65). This state of affairs was the byproduct of the region's historical and enduring relationship with resource extraction. Since Europeans arrived on the shores of the Bight of Biafra, economic activity in the region has focused on the extraction of local commodities for the global economy. Prior to the onset of colonialism, slave traders extracted human resources from the region (Harris 1942; Northrup 1976, 1979; Nwokeji 2010; Oriji 1986). Following the abolition of the slave trade, economic activity in the region shifted towards the extraction of palm oil, which the British relied on to lubricate the machinery of the industrial revolution (Martin 1988). Since Nigeria achieved its political independence, foreign companies have focused on drilling for "black gold" in the Oil Rivers of the Niger Delta, at a heavy cost to the local environment (Kashi and Watts 2008). This extractive economy incentivized both colonial and postcolonial politicians not to develop the southeastern part of the country. In the absence of meaningful economic development, sufficient material resources and abundant opportunities to access the sources of secular power, the peoples of southeastern Nigeria used religious organizations to facilitate socio-economic mobility and access to resources. As Marxist historian Caroline Ifeka-Moller has convincingly argued, religious change in southeastern Nigeria was facilitated by "the search for some kind of power on the part of people who would not otherwise control significant material resources" (Ifeka-Moller 1974, p. 65).

Anthony Obinna and his congregants believed that their membership in the LDS Church would provide them with access to resources and opportunities that were not accessible to them in indigenous prophetic churches or established mission churches. The magazine offprints about the church, produced in the 1950s, that Nigerians digested during the 1960s indicated as much. In the 1950s, the American media depicted the Latter-day Saints as a "model minority" (Chen and Yorgason 1999). One article, for instance, published in Reader's Digest in 1958, described the church in the following manner: "It is a self-reliant society, which distributes the bounty of all its people to any member in need. Mormons do not believe in government doles. A chain of farms, storehouses and granaries keeps on hand-together with what is stored by each family-enough food and clothing to supply every Mormon for a full year. There are opportunities for education equal to one's aptitude and a job worthy of one's ability" (Spence 1958 , p. 185). For Nigerians worried about their sense of security during wartime, the LDS Church, as described by the American media, offered a sense of security, opportunity, and access to resources that were not controlled by entrenched patronage networks or the Nigerian government. Throughout the 1960s and 1970s, Nigerians bombarded the LDS Church (and other American religious organizations, such as the Mennonite Church) with requests for economic relief and religious support (Hurlbut 2020, pp. 44-47; Yoder 2016, pp. 243-46, 257; Yoder 2013, p. 138).

The assumptions that Nigerians made about the LDS Church were not entirely wrong. Some tangible socio-economic and material benefits accompanied the Obinnas' acquisition of Mormonism. First, they gained access to resources that facilitated their ability to practice their new religion. LaMar Williams and other interlocutors at church headquarters in Salt Lake City, for instance, regularly 
sent Mormon literature, periodicals and scriptures to the Obinnas. ${ }^{44}$ They not only gained access to religious resources, but also modern technologies. On their experimental farm, for example, the Obinnas deployed cutting-edge agricultural machinery, such as tilling machines, that they had acquired with the assistance of Elliot Brooks, an American LDS missionary based in Owerri, who had the connections and ability to import agricultural equipment from America. ${ }^{45}$ Membership in the LDS Church also provided the Obinnas with the opportunity to pursue advanced education in the United States. Vitalois and Bonaventure Obinna, two sons of Anthony Obinna, for instance, were able to use their connections with the LDS Church to gain admission to Ricks College, a junior college in Rexburg, Idaho, owned by the LDS Church, which transitioned into a four year college and was renamed Brigham Young University, Idaho, in 2001. ${ }^{46}$ After two years at Ricks College, Vitalois went to Utah State University to study business. ${ }^{47}$ Bonaventure followed his brother to Utah State University, and eventually went on to study at Idaho State University. ${ }^{48}$ As these examples demonstrate, by joining the LDS Church, the Obinna family adapted a long-standing regional survival strategy, for achieving socio-economic mobility, to the changing realities of the postcolonial world.

\section{Conclusions: Making Sense of Religious Change in Postcolonial Southeastern Nigeria}

By placing the story of Anthony Obinna and his family within its larger cultural and historical context, this article offers an alternative social explanation to an important episode in Mormon history. While one historian has argued that the expansion of Mormonism in West Africa, particularly Ghana, is a story that "has the elements of a modern legend, tracing a triumphalist history" (Stevenson 2015, p. 222), this article shows that there was nothing exceptional about Mormon expansion in southeastern Nigeria. Nigerian engagement with Mormonism in Aboh Mbaise, as the example of the Obinna family demonstrates, conformed to broader regional patterns of religious engagement and cultural exchange.

This article also makes two contributions to the literature on religious change in Africa. First, this article rejects the idea that the process of "conversion" entails the replacement of one psychological state by another (cf. Nock 1933, p. 7). The example of Anthony Obinna shows that Nigerians were drawn to the LDS Church because of the elective affinities that existed between indigenous Igbo culture and Mormonism, and that they wanted to make the smallest possible departure from their indigenous culture. Second, this article demonstrates that the emphasis anthropologists and historians of religion have recently placed on the importance of rupture and discontinuity in the process of religious change is overstated (Bruner 2017; Engelke 2004; van de Kamp 2016; Robbins 2004). Outside of a Pentecostal context, cultural endurance and continuity play an important role in shaping not only processes of religious change, but also our understanding of religious "conversion".

Funding: This research was supported by a Graduate Research Fellowship in Mormon Studies (2018-2019) from the Obert C. and Grace A. Tanner Humanities Center at the University of Utah in Salt Lake City, Utah, and both a Summer Research Fellowship (2019) and a Summer Research Grant (2017) from the Department of History at Boston University in Boston, Massachusetts.

Acknowledgments: Thanks to Ian Barber, Jason Bruner, Brooke Blower, Robert Goldberg, Phillip Haberkern, James McCann, Victor Manfredi, Sarah Phillips, Ute Röschenthaler, Diana Wylie, and the two anonymous reviewers for the journal.

Conflicts of Interest: The author declares no conflict of interest.

44 Obinna, Letter to Council of Twelve, 28 September 1978, Box 1, Folder 1, Edwin Q. Cannon Papers, CHL; Obinna, Letter to Cannon, 10 November 1978, Box 1, Folder, Edwin Q. Cannon Papers, CHL; "Interview Between Dale LeBaron and Anthony U. Obinna, Aboh Mbaise, Imo State Nigeria, 4 June 1988," p. 22, Box 11, Folder 3, African Oral History Project, LTPSC.

45 "Gov Visits Private Farm," Folder 1, Obinna Family Papers, CHL.

46 "Interview Between Dale LeBaron and Anthony U. Obinna, Aboh Mbaise, Imo State Nigeria, 4 June 1988," p. 12, Box 11, Folder 3, African Oral History Project, LTPSC.

47 Ibid., p. 12

48 Ibid., p. 12 


\section{References}

Abasiattai, Monday B. 1989. The Oberi Okaime Christian Mission: Towards a History of an Ibibio Independent Church. Africa 59: 496-516. [CrossRef]

Adams, Robert Frederick George. 1947. Oberi Okaime: A New African Language and Script. Africa 17: 24-34. [CrossRef]

Afigbo, Adiele Eberechukwu. 1971. The Eclipse of the Aro-Slaving Oligarchy of South-Eastern Nigeria. Journal of the Historical Society of Nigeria 6: 3-24.

Allen, James B. 1991. Would-Be Saints: West Africa Before the 1978 Priesthood Revelation. Journal of Mormon History 17: 207-47.

Amadi, Gabriel. 1982. Power and Purity: A Comparative Study of Two Prophetic Churches in Southeastern Nigeria. Ph.D. dissertation, University of Manchester, Manchester, UK.

Boyer, Pascal. 2020. Why Diviniation? Evolved Psychology and Strategic Interaction in the Product of Truth. Current Anthropology 61: 100-23. [CrossRef]

Bruner, Jason. 2017. Living Salvation in the East African Revival in Uganda. Rochester: Rochester University Press.

Bunyan, John. 1678. The Pilgrim's Progress from This World, to That Which Is to Come: Delivered under the Similitude of a Dream Wherein is Divorced, the Manner of His Setting Out, His Dangerous Journey; and Safe Arrival at the Desired Countrey. London: Nath. Ponder.

Burgess, Richard. 2008. Nigeria's Christian Revolution: The Civil War Revival and its Pentecostal Progeny (1967-2006). Eugene: Wipf and Stock.

Chen, Chiung Hwang, and Ethan Yorgason. 1999. "Those Amazing Mormons": The Media's Construction of Latter-day Saints as a Model Minority. Dialogue 32: 107-28.

The Church of Jesus Christ of Latter-day Saints. 2013. The Doctrine and Covenants of the Church of Jesus Christ of Latter-Day Saints. Salt Lake City: The Church of Jesus Christ of Latter-day Saints.

Claremont Graduate University. 2019. The Mormonism and Migration Project. Available online: https://research.cgu. edu/mormonism-migration-project/ (accessed on 14 May 2020).

Daly, Samuel Fury Childs. 2017. Biafra's Crisis of Faith: The Spiritual Legacies of the Biafran War. The Republic, November 2.

Ellis, Stephen. 2008. The Okija Shrine: Death and Life in Nigerian Politics. Journal of African History 49: 445-66. [CrossRef]

Engelke, Matthew. 2004. Discontinuity and the Discourse of Conversion. Journal of Religion in Africa 34: 82-109. [CrossRef]

Forde, Daryll, and Gwilym Iwan Jones. 1950. The Igbo and Ibibio-Speaking Peoples of South-Eastern Nigeria. London: International African Institute.

Harris, Jack S. 1942. Some Aspects of Slavery in Southeastern Nigeria. Journal of Negro History 27: 37-54. [CrossRef]

Hau, Kathleen. 1961. Oberi Okaime Script, Texts, and Counting System. Bulletin de l'Institut Francais d'Afrique Noire 23: 291-308.

Hurlbut, D. Dmitri. 2015. Nigerian Converts, Mormon Missionaries and the Priesthood Revelation: Mormonism in Nigeria, 1946-1978. Working Papers in African Studies 268. Boston, MA, USA: African Studies Center, Pardee School of Global Studies, Boston University.

Hurlbut, D. Dmitri. 2017. The History of Christianity in Nigeria: A Bibliography of Secondary Sources. Working Papers in African Studies 269. Boston, MA, USA: African Studies Center, Pardee School of Global Studies, Boston University.

Hurlbut, D. Dmitri. 2018. The LDS Church and the Problem of Race: Mormonism in Nigeria, 1946-1978. International Journal of African Historical Studies 51: 1-16.

Hurlbut, D. Dmitri. 2019a. Gobert Edet and the Entry of the RLDS Church into Southeastern Nigeria, 1962-1966. Journal of Mormon History 45: 81-104. [CrossRef]

Hurlbut, D. Dmitri. 2019b. LDS Materials for the Study of Postcolonial Sub-Saharan Africa. International Journal of African Historical Studies 52: 301-10.

Hurlbut, David Dmitri. 2020. The Expansion of Mormonism in Southeastern Nigeria, 1960-1988. Ph.D. dissertation, Boston University, Boston, MA, USA.

Ifeka-Moller, Caroline. 1974. White Power: Social-Structural Factors in Conversion to Christianity, Eastern Nigeria, 1921-1966. Canadian Journal of African Studies 8: 55-72. 
Jenkins, Philip. 2009. Letting Go: Understanding Mormon Growth in Africa. Journal of Mormon History 35: 1-25. Jenkins, Ryan. 2011. Quiet Slumber: Revelation Through Dreams. Religious Educator 12: 73-89.

Jones, Gwilym Iwan. 1989. Recollections of the Spirit Movement in the Ibibio Area of Calabar Province. Africa 59: 517. [CrossRef]

Kalu, Ogbu U. 1977. Missionaries, Colonial Government, and Secret Societies in South-Eastern Igboland, 1920-1950. Journal of the Historical Society of Nigeria 9: 75-90.

van de Kamp, Linda. 2016. Violent Conversion: Brazilian Pentecostalism and Urban Women in Mozambique. Woodbridge: James Currey.

Kashi, Ed, and Michael Watts. 2008. Curse of the Black Gold: 50 Years of Oil in the Niger Delta. New York: PowerHouse Books.

Kline, Caroline. 2019. Anthony Obinna. 15 November. Youtube Video. 6:04. Available online: https://www.youtube. com/watch?v=yVxNYQd4-v4\&feature=emb_title (accessed on 19 May 2020).

LeBaron, E. Dale. 1996. Mormonism in Black Africa. In Mormon Identities in Transition. Edited by Douglas J. Davies. London: Cassell, pp. 80-86.

Löwy, Michael. 2014. Le Concept d'Affinité Élective chez Max Weber. Archives de Sciences Sociales des Religions 127: 93-103. [CrossRef]

Ludwig, Frieder. 1993. Elijah II: Radicalisation and Consolidation of the Garrick Braide Movement, 1915-1918. Journal of Religion in Africa 23: 296-317.

Mabey, Rendell N., and Gordon T. Allred. 1984. Brother to Brother: The Story of the Latter-day Saint Missionaries Who Took the Gospel to Black Africa. Salt Lake City: Bookcraft.

Manfredi, Victor. 2014. Comparison of 4-Bit Array Names and Associated Information from Oracle Localizations Across 5 Historical Zones. Available online: http://people.bu.edu/manfredi/4bitArraySpreadsheet.pdf (accessed on 27 March 2020).

Manfredi, Victor. 2015a. Áfa, the Nri-Igbo Counterpart of Ifá. Available online: http://people.bu.edu/manfredi/ IfaAfaNri.pdf (accessed on 27 March 2020).

Manfredi, Victor. 2015b. Before Wazobia: Ominigbon and Polyglot Culture in Medieval 9ja. Available online: People.bu.edu/manfredi/BeforeWazobia.pdf (accessed on 27 March 2020).

Manfredi, Victor. 2015c. Semantic Key for Duplex (8-Bit) Array Name Across Oracle Localizations. Available online: http://people.bu.edu/manfredi/8bitSemanticKey.pdf (accessed on 27 March 2020).

Manfredi, Victor. 2016. Ominigbon Facing Edo Past and Future. Umewaen: Journal of Benin and Edo Studies 1: 136-41.

Manfredi, Victor. 2017. Icons and Oracles Across the Confluence. Available online: http://people.bu.edu/manfredi/ MetaphysicalMigrations.pdf (accessed on 27 March 2020).

Martin, Susan M. 1988. Palm Oil and Protest: An Economic History of the Ngwa Region, South-Eastern Nigeria, 1800-1980. Cambridge: Cambridge University Press.

Mbon, Friday. 1986a. Brotherhood of the Cross and Star: A Sociological Case Study of New Religious Movements in Contemporary Nigeria. Ph.D. dissertation, University of Ottawa, Ottawa, ON, Canada.

Mbon, Friday. 1986b. The Social Impact of Nigeria's New Religious Movements. In New Religious Movements and Rapid Social Change. Edited by James A. Beckford. Paris: United Nations Education, Scientific, and Cultural Organization (UNESCO), pp. 177-96.

Mbon, Friday. 1992. Brotherhood of the Cross and Star: A New Religious Movement in Nigeria. Franfurt am Main: Peter Lang.

Moller, Caroline Victoria Margaret. 1968. An Aladura Church in Eastern Nigeria. Ph.D. dissertation, University of London, London, UK.

Nock, Arthur Darby. 1933. Conversion: The Old and the New in Religion from Alexander the Great to Augustine of Hippo. Oxford: Clarendon Press.

Northrup, David. 1976. The Compatibility of the Slave and Palm Oil Trades in the Bight of Biafra. Journal of African History 17: 353-64. [CrossRef]

Northrup, David. 1979. Nineteenth-Century Patterns of Slavery and Economic Growth in Southeastern Nigeria. International Journal of African Historical Studies 12: 1-16. [CrossRef]

Nwaka, Jancinta Chiamaka. 2013. The Catholic Church, the Nigerian Civil War, and the Beginning of Organized Lay Apostolate Groups among the Igbos of Southeastern Nigeria. Catholic Historical Review 99: 78-95. [CrossRef] 
Nwokeji, G. Ugo. 2010. The Slave Trade and Culture in the Bight of Biafra: An African Society in the Atlantic World. Cambridge: Cambridge University Press.

Obinna, Anthony Uzodimma. 1980. Voice from Nigeria. Ensign. December. Available online: https://www. churchofjesuschrist.org/study/ensign/1980/12/voice-from-nigeria?lang=eng (accessed on 13 July 2020).

Oriji, John N. 1986. Slave Trade, Warfare, and Aro Expansion in the Igbo Heartland. Geneve-Afrique 34: 108-18.

Ottenberg, Simon. 1958. Ibo Oracles and Intergroup Relations. Southwestern Journal of Anthropology 14: $295-317$. [CrossRef]

Pratten, David. 2007. Mystics and Missionaries: Narratives of the Spirit Movement in Eastern Nigeria. Social Anthropology 15: 47-70. [CrossRef]

Ray, Keith. 1992. Dreams of Grandeur: The Call to Office in Northcentral Igbo Religious Leadership. In Dreaming, Religion, and Society in Africa. Edited by Marian Charles Jedrej and Rosalind Shaw. Leiden: Brill, pp. 55-70.

Robbins, Joel. 2004. Becoming Sinners: Christianity and Moral Torment in a Papua New Guinea Society. Berkeley: University of California Press.

Röschenthaler, Ute. 2004. Transacting Obasinjom: The Dissemination of a Cult Agency in the Cross River Area. Africa 74: 241-76. [CrossRef]

Röschenthaler, Ute. 2011. Purchasing Culture: The Dissemination of Associations in the Cross River Region of Cameroon and Nigeria. Trenton: Africa World Press.

Spence, Hartzell. 1958. The Mormon Church: A Complete Way of Life. Reader's Digest 72: 184-90.

Stevenson, Russel W. 2014. For the Cause of Righteousness: A Global History of Blacks and Mormonism, 1830-2013. Draper: Greg Kofford Books.

Stevenson, Russell W. 2015. "We Have Prophetesses": Mormonism in Ghana, 1964-1979. Journal of Mormon History 41: 221-57.

Taylor, Lori Elaine. 2019. Joseph Smith in Iroquois Country: A Mormon Creation Story. In Essays on Native American and Mormon History. Edited by P. Jane Hafen and Brendan W. Rensink. Salt Lake City: University of Utah Press.

Uchendu, Victor U. 1965. The Igbo of Southeastern Nigeria. London: Holt, Rinehart, and Winston.

Woodger, Mary Jane, Kenneth L. Alford, and Craig K. Manscill. 2019. Dreams as Revelation. Salt Lake City: Desert Book.

Yoder, R. Bruce. 2013. Mennonite Mission Theorists and Practitioners in Southeastern Nigeria: Changing Contexts and Strategy at the Dawn of the Postcolonial Era. International Bulletin of Missionary Research 37: 138-44. [CrossRef]

Yoder, Robert Bruce. 2016. Mennonite Missionaries and African Independent Church: The Development of an Anabaptist Missiology in West Africa: 1958-1967. Ph.D. dissertation, Boston University, Boston, MA, USA.

(C) 2020 by the author. Licensee MDPI, Basel, Switzerland. This article is an open access article distributed under the terms and conditions of the Creative Commons Attribution (CC BY) license (http://creativecommons.org/licenses/by/4.0/). 

Article

\title{
Conversion as Negotiation. Converts as Actors of Civil Society
}

\author{
Katrin Langewiesche \\ Anthropology ad African Studies, Johannes Gutenberg University of Mainz, 55122 Mainz, Germany; \\ langewie@uni-mainz.de
}

Received: 23 May 2020; Accepted: 26 June 2020; Published: 30 June 2020

\begin{abstract}
This article focuses on the religious movement of the Ahmadiyya and its civil society organization, Humanity First, in West-Africa and in Europe. Particular attention is paid to the place of converts within these two institutions. Conversions to an Islamic minority and the actions of this minority are studied through the prism of social commitment. I examine the intersections between religious values, the ideas of solidarity in the societies under scrutiny, and the kaleidoscopic range of Muslim charities. The paper investigates conversion as negotiation in regard to gender, social mobility, and power. Conversion is approached here as a matter of social relations and not personal belief. I argue that converts have to use various strategies of recognition, either as individuals or as a group, which places them in a permanent state of negotiation with their entourage.
\end{abstract}

Keywords: conversion; social engagement; faith-based NGO; Ahmadiyya; Burkina Faso; France

\section{Introduction}

This article examines social engagement in connection to conversion by means of the example of the religious movement of the Ahmadiyya and its civil society organization-Humanity First-both in West-Africa and in Europe. Particular attention is paid to the place of converts within these two institutions. The Ahmadiyya community, like many religious groups, is committed, alongside its religious activities, to the development of society and the care of vulnerable people. The ability to ensure social integration of the marginalized through religious self-help networks can only be analysed satisfactorily if it is seen as rooted in society as a whole. Ideas that prevail over practices of solidarity and charity are either in line with or in opposition to other normative systems of the society considered, such as the legal requirements of the state or the norms and values of kinship (Thelen et al. 2009). The manner in which social commitment is practised in religious networks is also closely linked to the presence of other religious or social providers of social solidarity such as religious NGOs, churches, and international agencies.

Likewise, conversions can only be understood in context. Although it is an intimate process, some aspects of which escape sociological apprehension, other aspects are socially determined. The logic of a conversion depends as much on the individual dispositions of converts as on their social and family relations, which generates social effects (Hervieu-Léger 1999). In a sociological perspective, therefore, it is not the individual experience that interests me to tackle in this article, but the social consequences of a conversion, more precisely of a conversion to a minority religious movement. The minority status of Ahmadiyya is mainly linked to the doctrine of this movement, described by some as heterodox, by others as non-Islamic, but also in connection to their minority demographics, whether in France and Burkina Faso, the two countries under scrutiny here, or within the overall Muslim population. Independent sources estimate that the community gathers between 10 and 20 million members 
worldwide, which approximately amounts to $1 \%$ of the world's Muslim population. ${ }^{1}$ In France, the Ahmadis represent a minority of some 2000 people, and in Burkina Faso about 65,000 according to their own estimates. ${ }^{2}$

Networking between, on the one hand, African and European Ahmadiyya communities, and on the other, Humanity First groups in Africa and Europe, are important factors in the development of the religious and social aspects of the movement. It may therefore prove insightful to examine the Ahmadi community and its NGO in two countries in Europe and Africa, where the two organizations have reached different stages and where their evolution can be surveyed.

In the first part, I present the Ahmadiyya movement and its NGO Humanity First in Burkina Faso and France. The second part investigates the intersections between religious values, the ideas of solidarity in the societies considered, and the kaleidoscopic range of Muslim charities through case studies that highlight the role of conversion as a "negotiation" with regard to gender, social mobility, and power.

\section{Fieldworks, Methodology, and Concepts}

My interest in the activities of the Ahmadiyya Muslim Community began in 2009 with a series of interviews I conducted with employees and the doctor of the Ahmadi hospital in Ouagadougou, the capital of Burkina Faso, who allowed me to participate in many medical outings in villages around the capital, in distributions of medicines in the prison, and observe cataract operations. In 2014 and 2015, I carried out systematic research in France, Germany, Burkina Faso, Ghana, and Benin, by following the activities of various Ahmadi communities and participating in their events, in particular the Jalsa Salana, an annual meeting dedicated to prayer, which is organized in every country hosting an Ahmadi community. Since 2016, I have repeatedly attended conferences, ceremonies, and festivals of the Ahmadi communities in France and Burkina Faso, as well as followed the activities of Humanity First. Since the end of 2019, I have regularly participated in the activities of Humanity First in France, particularly in Ile-de-France region, surrounding Paris.

In all these years, I have privileged biographical interviews over the collection of isolated conversion stories. The biographical approach makes it possible to identify patterns in individual religious trajectories, while preserving the singularity of each social actor (Bertaux 1980). Investigation by means of biographical narratives enables access to both autobiographical discourses and information about an individual viewed as the witness of his or her time and environment (Poirier and Raybaut 1983). However, the conversion narrative took such a place in the stories of my interlocutors that it was impossible not to dwell on it. In order to distance myself from these stories, to escape their dogmatic and standardized logic, I met the same people several times, sometimes over the course of a few months or years, and I mostly participated in meetings of Humanity First volunteers, outings to retirement homes, on occasion of their streets roaming, skype events for converts, and religious ceremonies.

The corpus on which I rely for this article is predominantly composed of interviews with women. The oldest conversions date back some twenty years. According to the terminology of the Ahmadis themselves, these are no longer "converts," but full members of the community. The status of convert is reserved to people who have embraced Ahmadiyya Islam for less than three years.

1 (Minahan 2002): 52 and World Religion Database 2016 quoted by http://a-m-l.blogspot.fr/2017/07/ahmadiyya-population-inworld-2016.html accessed 11/3/2018.

2 In Burkina Faso, Muslims represent about $60.5 \%$ of a total population of about 20 million, with a strong regional difference. The capital Ouagadougou has a population of almost 3 million, of which about 57.7\% are Muslims (Pilon et al. 2019; https://www.populationdata.net/pays/burkina-faso/). In France, the law prohibits the collection of data on ethnic or religious affiliation; however, extrapolation of existing data permits to estimate the number of Muslim citizens at 4 or 5 million, about $7.5 \%$ of the French population. The Ile-de-France region has a population of over 11 million and is home to between 12 and 15\% of Muslims (Muslims in Europe. Report by Open Society Foundations paris-20120723-EN.indd accessed 29 April 2019; Jonathan and Vaïsse 2007). 
My empirical studies are embedded in the theoretical discussion of the complex relationship between social engagement and conversion. The opposition between the merely individual and private engagement, which conversion represents in the perception of those concerned and their public engagement, calls into question the public/private opposition (Casanova 1994; Habermas 1992). The relevance of the distinction between a public and a private sphere has often been discussed (Holder 2009; Salvatore 2005). However, the notion of social engagement retains its explanatory force as a personal involvement in an action that goes beyond the individual (Le Pape 2007). Social engagement includes a wide range of actions from individual voluntary work to the professional practices of an organization. It can take the form of immediate social or humanitarian assistance, but also long-term social change with overt or secondary political objectives. At the heart of social engagement is the longing for improving the living conditions of individuals or for helping shape the future of the disadvantaged. In many cases, but certainly not always, religion plays an important role in this participatory ethic (Allahayari 2000; Molokotos-Liederman et al. 2018; Adams 2013). Analysing the reasons for individual conversion allows us to sketch the connections between the realms of the religious and of the social. The motivations evoked by converts to Ahmadi Islam highlight the close links between religious practice, spiritual aspirations, and the social life of the individual. Even if conversion "is rooted in both self and society" (Jules-Rosette 1975, p. 132), in this article, I approach conversion as a matter of social relations and not personal belief. Many authors have discussed in different-both Christian and Muslim-geographical and historical contexts the usefulness of the concept of conversion for sociological analysis, and have helped distinguish it from its theological or psychological meanings, which refer to a profound change of being. (Allievi 1999; Beckford 1989; Blakely et al. 1994; Comaroff and Comaroff 1991; Hervieu-Léger 1999; Mary 1998; Mossière 2009; Lofland and Stark 1965; Snow and Phillips 1980; Peel 1990; Van Der Veer 1996). A reflection on conversion that emphasizes its links with social commitment must recognize the variability of experiences and analyse their genesis in different social, intellectual, and religious milieus. Even if conversion is interpreted as the acceptance of a new definition of the self, as a new reference point for the construction of individual identity, it must be acknowledged that this is a new reference point that supplements others that already interact with each other (Hefner 1993; Meintel 2003; Langewiesche 1998). ${ }^{3}$ Conversion, although perceived as a radical change by those concerned, reminds us of the interdependence between two conditions. One before and one after, they mirror each other, more often than not, they impose a compromise. Similarly, a negotiation involves a compromise between parties. Each of the parties feels it gets its due in reaching an agreement, and gains satisfaction or even an advantage judged best given the circumstances. Conflictual duality has given way to a balance of forces, but not without leaving a certain residual tension. A precondition for finding common ground is the acceptance of the other in its otherness. In this sense, conversion and negotiation come together in their capacity to generate a social bond. Paraphrasing Thuderoz (2009), one could say that the contemporary process of differentiation affecting society and individuals, as well as the religious diversity of modern societies multiply conflicts, establish a permanent debate on values, and thus increase not only the need for negotiation but also potential conversions. The volume edited by de Terssac (2003) allows for the identification other points of connection between negotiation and conversion. The two notions are similar in that they develop the idea of constructing compromises and reciprocal action; they make room for identity transformations, linked to the learning that takes place in the course of interaction; and they start from the identification of a situation of uncertainty and/or conflict (Schurmans 2013). Any negotiation or conversion requires a plan, an intention. In both cases, the fulfilment of this intention produces new actors, new rules or new situations. Converts go through a process of negotiation between one condition and another that leads them to something

3 In order to emphasize the possibility of floating between several points of reference, I have proposed elsewhere the notion of "religious mobility" to complement in certain circumstances that of "conversion." (Langewiesche 2003, pp. 54-90). 
new. The conversion can then be seen as a negotiation between two statuses. Starting from this first experience of negotiation and adaptation in their personal life, converts negotiate in a second step their position in the religious group which they integrate through their social commitment and the challenges it sets for them.

Various scholars note a trend that departs from mere religious activism, and, instead, tends to combine religious and humanitarian or social commitment. This perspective makes it possible to consider the religious practices of converts in the light of the individual, social, and political constraints imposed upon them. Youth organizations of the churches or women's groups of the mosque do not confine themselves to merely religious activities anymore, but are increasingly involved in civil society (LeBlanc 2012; Soares and LeBlanc 2015). This tendency towards what Paul Gifford calls the "NGO-ization" of associations and religious groups in many African countries intensified along the 1990s. He describes this changing nature of Catholicism as a move towards becoming a development institution from a redemption one (Gifford 2015, p. 103). Many authors have studied this trend in relation to Pentecostal churches, whose connections with neoliberalism and development is widely recognized (Bornstein 2003; Freeman 2012; Coleman 2000; Gifford 2004). The Ahmadiyya founded organization, i.e., Humanity First, is one of the Muslim NGOs that illustrates, in the Islamic field, the tendency of increasing involvement of faith-based initiatives in civil societies. Petersen has related this approach to the development of Muslim faith-based Organizations as being situated in-between a "sacralised" and "secularized" form of aid (Petersen 2015). The involvement of local Muslim associations and transnational movements in education, healthcare services, and development issues penetrated into most West African countries a few years after the Catholic and Protestant initiatives were launched, and often in reaction to the latter (Langewiesche 2011; Sounaye 2011). Islam and its charities have received less attention than Christian organizations, but there is anyhow a growing number of case studies in this area (Benthall and Bellion-Jourdan 2003; Benthall 2005; Sadouni 2009; Savadogo et al. 2016; Skinner 2010; Weiss 2020). However, if there has been extensive research on the role of religious NGOs to tackle poverty in Africa or Asia, there are fewer studies on the role of Muslim NGOs working in the West, particularly in France. ${ }^{4}$

\section{Ahmadiyya and the NGO Humanity First in Burkina Faso and in France}

The Ahmadiyya Muslim Community is one branch of the Ahmadiyya founded in 1889 by Mirza Ghulam Ahmad, an Indian Muslim scholar (1835-1908). Within the group, there were theological differences and disagreements regarding the founder's successor, which prompted the splitting of the movement into two groups as early as 1914: on the one hand, the Lahore Ahmadiyya (Ahmadiyya Anjuman-i Isha'at-i Islami-AAII), and the Ahmadiyya Muslim Community (Ahmadiyya Muslim Jama'at-AMJ) on the other hand. ${ }^{5}$ The vast majority of Ahmadis in the world today are part of the Ahmadiyya Muslim Community, whose administrative headquarters have been in London since 1984 because the Ahmadis are persecuted in their home country, Pakistan (Ahmed 2012). My investigations were limited to the Ahmadiyya Muslim Community branch of the Ahmadiyya.

The Ahmadiyya Muslim Community holds a special position within contemporary Muslim movements. Its members consider themselves Muslims, but they are not recognized as such by the majority of Muslims. There are several reasons accounting for this. The main reason is that the Ahmadis believe their founder not only is a reformer of Islam but is the promised Messiah and Imam Mahdi. Non-Ahmadi Muslims view this belief as in contradiction to the dogma that Mohammed is the "Seal of the Prophet." Beside the interpretation of the prophet's doctrine, Ahmadiyya differs from other Muslims mainly in the interpretation of the Jihad concept and the doctrine on Jesus (Lathan 2008).

4 For Switzerland: Martens (2014), for Germany: Ozkan (2012) and for England: Kroessin (2009).

5 For more details on these two branches and on the outsider situation of the Ahmadiyya Muslim Community, see Lathan (2008). 
The movement was introduced into Burkina Faso around 1950, but it became really visible in the public arena in the 2000s (Cissé and Langewiesche 2019). In West Africa, the largest Ahmadi community is now established in Ghana (Hanson 2017). In France, the Ahmadiyya Muslim Community was established in the late 1980s, after a first, unsuccessful attempt in $1946 .{ }^{6}$ The largest Ahmadi communities in Europe today are present in Great Britain and Germany (Jonker 2016; Lathan 2010).

The international Ahmadiyya Muslim Community offers a wide range of social services and charities to its members and to all people in need. However, since 1995, the religious movement has also set up a humanitarian organization: Humanity First, an NGO devoted exclusively to humanitarian aims and whose activities benefit the entire population of a country and are explicitly not associated with proselytizing. The international website of the NGO does not in any way refer to its ties with the Ahmadiyya Muslim Community, and the various national Humanity First websites do so in passing. The proximity to Islamic values can only be deduced by visitors of these websites from the actions of the NGO. In its web presentation and also in the interviews I conducted with the leaders, the organization does not define itself as an Islamic NGO (Langewiesche 2020b). It sees itself as a humanitarian association and is eager to cooperate with secular or Christian institutions and NGOs, as well as with the authorities in the countries where they operate. Humanity First was founded in 1995 by the fourth khalifa of the Ahmadiyya Muslim Community (Hazrat Mirza Tahir Ahmad). This foundation was rooted in the idea that a religious-neutral organization might give an opportunity to all "noble souls," regardless of their religious affinity, to devote themselves to a "noble task" without being eventually discouraged by the Muslim identity of the NGO (Interview Härter, 2014). Non-Ahmadis and Ahmadis therefore work together within Humanity First. Nevertheless, nearly all managers are Ahmadis as well as the vast majority of the members, particularly in Africa. In Europe not all volunteers belong to the religious community (jama'at). They are Christians, Muslims, or do not practise any religion. The Humanity First groups in the Global South are supported by Humanity First Groups in Europe or America. Most of the donations are made by members of the Ahmadiyya community, in the form of zakat (compulsory charity) or sadaqa (voluntary charity) donations. Ahmadis can settle their annual zakat donation via Humanity First, thus contributing to the dissemination of Islam through its contribution to Humanity First. In todays' context, the obligatory almsgiving becomes the source of communal and collective improvement not only for Muslims in need, but for all the needy. On the other hand, the policy of development cooperation or engagement for the needy is interpreted as a religious practice and an example of worshipping. The spiritual blessing experienced by those who devote themselves to help the Others was also clearly emphasized by the khalifa in a speech he gave in 2015:

"The benefit of serving others is such that the Promised Messiah" has aligned human compassion with spirituality by stating that loving others is a great means of worship and a way to attain Allah's blessing and rewards" (Keynote Address at the International Conference of Humanity First in the Baitul Futuh Mosque (UK) 2015).

While the Ahmadiyya Muslim Community is a missionary group committed to active proselytism, their NGO was and is still excluded from all missionary activities. In fact, I have never observed that, during or after medical activities, food distribution, or charitable visits, religious literature was being distributed or preaching was occurring. According to this understanding of separation of mission and social work, conversions to Ahmadi Islam are viewed as a by-product of the members' exemplary peaceful life and their commitment to humankind. Nevertheless, the khalifa and the tabligh (preaching) department of every country set up a "conversion scheme" based on the request of the khalifa to gain a

6 The French Ahmadiyya Muslim Community purchased their first building in 1985, where the Amir office is currently located. At that time there were no more than about twenty Ahmadis in France. The group was made up of Mauritian immigrant workers, Ahmadi by birth, and was gradually supplemented by Pakistani Ahmadi refugees, and then by Muslims of other nationalities who accepted Ahmadi Islam. In 2008 the Ahmadiyya Muslim Community inaugurated their first mosque in France in St. Prix (Val de l' Oise) (Interview Amir, May 2014). 
certain number of new members in each country. Conversion is an important task for all Ahmadis to engage with. According to the understanding of the Ahamadiyya, conversion is considered to be a training and testing process that brings the converts from the status of "non-member" to that of "active member." This process starts with a bai'hat ceremony where new followers pledge their loyalty and obedience to the khalifa and conform to the 10 conditions that will make of them full member of the Ahmadiyya. After the bai'hat every new faithful is considered a convert (naw mobaine) for the next three years. They undergo a religious training that requires a significant personal investment. The religious training of the converts as well as the guidelines constantly provided to all members are highly institutionalized and thoroughly organized. Depending on the needs of each mission centre, they organize evening courses to teach the reading of the Koran, weekend meetings of converts, discussions around the founder's writings via skype, question-and-answer sessions with the imam, courses to learn Urdu or Arabic, etc. In addition to this varied offer adapted to the specific needs of the persons interested, there is a large grey literature distributed free of charge or made available to converts. They are also invited to regularly write letters to the khalifa to establish a personal bond with the leader. ${ }^{7}$

The Ahmadiyya is a Muslim minority that must adapt their activities and priorities to the diversity of the surrounding Muslim and Christian lifestyles in order to be accepted in the host society. The stakes for a minority group lie in how it positions itself in relation to other religious groups, and competes with them in the public arena. The NGO Humanity First can be considered as a catalyser for the religious movement to be accepted by the Christian or Muslim majority.

In Burkina Faso, Humanity First is not the only Muslim NGO. Local Islamic associations, especially among the Sufi Brotherhood of Tijaniyya Hamawiyya and among the Salafis of the Mouvement Sunnite with their specific social welfare activities, have been present in Burkina since the 1970s (Audet Gosselin and Couillard 2019; Vitale 2019). Other Christian and Muslim/Christian mixed NGOs emerged in the 1970s in an attempt to respond to the dramatic droughts in the Sahel. Nowadays, every Islamic NGO is working independently even though they all are engaged in very similar projects: financing schools, orphanages, health care centres, sewing courses, constructing wells, and funding cataract operations. In Burkina Faso today, at least 20 Islamic NGOs, 40 Christian NGOs and 1 mixed NGO are operating, along with more than 300 non-religious NGOs, only in the health care sector. As a consequence, there can exist a strong competition between different NGOs as they try to obtain funding from and legitimacy within the state and international structures. While cooperation with other Muslim Groups or Islamic NGOs in Burkina is challenging for Humanity First because of the outsider position of the Ahmadiyya Muslim Community, the organization clearly expresses its willingness to cooperate with Christian or non-religious NGOs and the state. Being recognized by the state is crucial for the Amadiyya Muslim Community in order to assert themselves in relation to the Muslim majority and to gain legitimacy. By building schools and complying with the state schools' curriculum, by integrating their healthcare centres into the national scheme, Humanity First is one of the transnational Islamic NGOs that align their activities with public policy. The recognition by the state of Humanity First helps the Amadiyya to portray itself as a modern religious actor that articulates religion and progress by offering high-level education, state-of-the-art health care, and technical innovations for rural development (Langewiesche 2020b).

In France, Muslim social commitment began in the 1970s in the wake of various migratory movements, often in the suburbs of large cities such as Paris and Marseille, Lyon. As well as in Burkina Faso, Muslim social engagement started by means of local associations. Some of these associations are linked to transnational movements such as the Tabligh or the Muslim Brotherhood. Yet many of them have no specific affiliation (Bouzar 2001; Brodard 2011). Several authors have emphasized the predominance of the communitarian character of Islamic social investment in France. Neighbourhood

7 For more details about the relationship with the charismatic leader, see Langewiesche (2020c) forthcoming. 
networks, mutual aid, and solidarity directed towards a particular community were launched and gradually, from the end of the 1990s, broadened their scope to reach out society as a whole and people in need (Diop 1989; Timera 1997; Quiminal and Timéra 2002; Frégosi 2009). Since the end of the 2000s, some international Muslim organizations have earned recognition on the French public scene to tackle poverty, such as Secours Islamique France $(\mathrm{SIF})^{8},{ }^{8}$ Muslim Hands France ${ }^{9}$, and the Red Crescent (Benthall 2005). Compared to these NGOs, Humanity First is a small NGO that has been active in France, particularly in the Ile de France region, since 2003. Despite its small number of volunteers and its limited means, Humanity First can be compared to the large international Islamic NGOs for its professionalism and its intervention alongside secular and Christian social action. Several of my interlocutors express their wish but also difficulties to work with the local authorities' social services. As for other NGOs, their outreach to the whole of society is the basis of their recognition in France. Like all other Muslim NGOs, they are involved in helping the homeless, women in distress, and refugees. They also visit nursing homes so that the elderly feel less isolated.

What is the role of converts within Humanity First in France and Burkina Faso?

In France, $87 \%$ of Humanity First's members are Ahmadis and 13\% are of other confessions or without religious affiliation, while in Burkina Faso all members of the NGO are at the same time part of the religious movement. In France and Burkina Faso, 99\% of the Ahmadiyya affiliated members of Humanity First are converts. In France, the new followers of Ahmadiyya are mostly Muslims of North African or African origin, and a minority are Christians. In France, as everywhere in Europe, the Muslim presence is linked to variations in migratory flows. In Burkina Faso, they are Burkinabé who were mainly Muslims before joining the Ahmadiyya. The sociological data of the converts requires a detailed analysis in order to shed light on the investment of individuals in society. ${ }^{10}$ The willingness to act and to influence the public authorities and other Muslim associations not only demonstrates that religious commitment is not necessarily confined to the private sector, but also makes it possible to put forward the hypothesis that religious commitment is largely dependent on the relations that the religious community maintains with other Muslim movements in its host country and with the public authorities (Le Pape 2007).

\section{Conversion as Negotiation: Gender, Social Mobility, and Power}

Two excerpts from my field logbook during roaming conducted in Paris in 2019 and in a medical camp in Maco, the central prison of Ouagadougou in 2011, allow me to underline that social engagement of converts can only be understood in the context of the associative and charitable environment in the countries in question. The two following individual stories of converts in France and in Burkina Faso, both involved with Humanity First illustrate that in contexts of religious plurality and in secular states a conversion, and the social commitment it shapes, can be interpreted as a process of negotiation in order to assert oneself vis-à-vis men, the Pakistani culture, potential employers, or the family.

"Everything is ready for our departure. The soup has been poured in bowls by the women and their children, the men carried all the bags with the snacks, thermos flasks and crates with about 100 bowls of soup in the two cars waiting at the back of the building. There is a discussion about where to start the distribution, only at the Gare de l'Est Station or already on the way. Some think that it should be distributed to all the poor people we spot, at the traffic lights, on pavement etc. Others think that it is better to concentrate on one place since there are the regulars will be waiting there. Michel ${ }^{11}$

8 SIF was member of the NGO Islamic Relief and is now independent (Lahlou 2018). Islamic Relief Worldwide was founded in 1984 by Egyptian Hany El Banna. It has become the world's largest international Islamic humanitarian organization and has branches in most Western countries.

9 Established in France since 2007 they are part of Muslim Hands International founded in the UK in 1993.

10 The research, which explains the trajectories of individuals who were not socialized in Islam and adopted it as teenagers or adults, now covers a large number of European national contexts. In contrast, very few of these studies refer to conversions to Ahmadi Islam (e.g., Wohlrab-Sahr 1999). A recent review of conversion to Islam can be found in Galonnier et al. (2019).

11 All names of volunteers and converts have been changed. 
notes that this would also make it possible to perpetuate our location in front of the Gare de l'Est station vis-à-vis the other associations that do the same kind of roaming. "Returning to the same place also increases our visibility," he argues. We still have to wait for one of the women to finish her prayer and we leave slightly late. The volunteers are worried about this delay, because they fear that the soup will have turned cold upon arrival at the Gare de l'Est Station. Traffic is still difficult because of the strikes. We learn along the way that thanks to our delayed departure we have avoided the closure of some streets. It is a miracle that Allah has sent us to bless our action, says Rachel. At Gare de l'Est the soups are distributed at full speed. This takes much less time than the preparation. On the way back one of the volunteers tells me: "It feels good to help the poor. For me, it's vital. I don't feel good if I don't do it. Sometimes I want to buy myself a nice dress, but I refrain myself and put the money I'd spend on the dress for donations. Then I feel good". Miriam explains, "It's important for us women to go out and see the effects of our actions first-hand. If it's only the boys who go out to distribute... I mean, the ones who stay at home and are limited to fundraising, they don't understand the urgency of the needs. Personally, I want to go out into the streets and talk to women who are struggling. Men can't approach them, they're afraid of them. We must do it!"' (Paris, December 2019).

Miriam refers to a recent controversy in the community regarding women's participation in the roaming organized by Humanity First. The leaders of the Ahmadiyya women's section have spoken out against women's outings, stressing the dangers of possible attacks and the risk of women ending up in inappropriate situations, in close proximity to men during these rounds. Officials are trying to use their authority within the Jama'at to deter Humanity First activists from taking homeless people off the streets. They suggest directing their engagements to other needy people such as elderly people in retirement homes. But Miriam and the other volunteers are not inclined to comply with this request. They especially want to work with women on the street or in shelters for isolated women. They interpret the attempts of the religious hierarchy to prevent them from doing so as an expression of Pakistani culture, since all the leaders are from Pakistan. "In their home country, that's why women are isolated. They only go out to go to the mosque. Don't make me believe that it is because of Islam that they stay at home in France too. It's their customs." In spite of this disagreement, the activists try to find a compromise by making two teams, one visiting the retirement homes and the other roaming, or sometimes combining both activities during the same weekend. What appears here is the wish of these activists for a shift from the institutional, national, and vertical model to horizontal and localized operations. We also find here a recurrent discourse around the difference between "culture" and "Islam" that we can identify under different traits in the Muslim world (Ewing 2015) and among converts (Galonnier et al. 2019).

Most Humanity First volunteers are also involved in other self-help associations or have been involved for some time in other initiatives to support migrants, homeless people, women in distress, etc. But they particularly appreciate the atmosphere at Humanity First because they share the same values with the sisters and brothers of the jama'at. Some of them combine a commitment to Humanity First with responsibilities in other Ahmadi associations or within the jama'at. It is their social investment in multiple organizations and the desire to coordinate their actions with those of municipal officials that gives them a valuable knowledge of the local associative field. This knowledge allows them to adjust their places of intervention according to the other social workers on the field.

While the commitment of Humanity First volunteers is characterized by a certain versatility, as Duclos and Nicourd (2005) found for most of the associations they studied, the core group of Humanity First activists can quickly mobilize supporters in times of need-such as during the Coronavirus pandemic - through Ahmadiyya networks. All members of the religious organization are potential volunteers for the NGO. To ensure the distribution of food during the lockdown, Ahmadiyya women mobilized to prepare hundreds of sandwiches every Saturday, which Humanity First activists would collect from their homes and distribute them in the usual places. Humanity First also prepared a leaflet offering outreach services, such as running errands for neighbours. Each Ahmadiyya member could, on behalf of Humanity First, put this leaflet in the mailbox or under the door of their neighbour. 
Mireille belongs to Humanity First's hard core. As soon as she heard that a section had opened in France, she contacted the director to offer her services. Supported by her religious conviction, she uses her professional skills in fundraising and her social networking skills to manage the volunteers. She joined Humanity First two years after joining Ahmadiyya. She signed the bai'hat thanks to her younger brother who has been telling her about the jama'at for years. But some doubts about the doctrine and also an apprehension about her parents' reaction held her up for a long time. Socialized in a large, practising Muslim family, she dreaded the reaction of her relatives. Although financially independent, being married and living far from her parents, she would have appreciated the blessing, especially by her father, for her conversion to Ahmadi Islam. A few years after her father died, a dream she had one night was finally decisive for her to request an interview at the community's headquarters in France, at St. Prix, in order to obtain clarification regarding certain theological issues and an interpretation of her dream. This dream, and the following afterwards, always reassured and confirmed her in her choice, despite the virulent reaction of her uncle, her father's brother, and other members of the family. These dreams also confirmed her humanitarian impulse. Since her arrival in France, she has been committed to the poor through donations and involvement in various Catholic-inspired and public local associations. It was therefore natural for her to also participate in the humanitarian organization of Ahmadiyya. That is where she has felt surrounded by volunteers who share her vision of charity. Her commitment to the most destitute, and in particular to women in distress, in the name of her religion also allows her to highlight certain points on which her personal opinion diverges from the habits of the religious movement, such as the investment of women in the public arena, the wearing of the veil, and financial participation in the religious movement. She believes that women have a place in the streets social work, that the wearing of the veil should be adapted to life circumstances, and she prefers to make donations to Humanity First instead of participating in the financing of religious events or the running of the mosque.

Beyond its exceptionality, Mireille's story recalls the importance of dreams for converts to Ahmadiyya (Balzani 2010). All my European interlocutors refer to very strong dreams or signs, ranging from miracle to providence, to explain their decision. If Mireille committed herself only 2 years after her conversion to Humanity First, it is because no group existed previously in France. For most of the European converts I met, the commitment to Humanity First went hand in hand with their joining the religious community, sometimes it was even what triggered their conversion. The characteristics of Humanity First, the framework that the NGO offers, helps strengthen the wish to join the religious movement, to make conversion conceivable, or to reinforce the initial motivations. Mireille's experience also illustrates that in front of a centralized religious movement run by Pakistani men and women, the space where it is possible for converts to make decisions for the common good and to make collective choices remains its humanitarian and charitable section. Within the NGO, women converts need to find distinctive elements that lend legitimacy to their cause and be fairly convinced of the merits of the cause or of the possibility of bringing an additional competence to it. When dealing with men and Pakistani influence in a religious organization with well-established roles institutionalized by sub-organizations according to the age classes, separated for men and women, the converts' actions are aimed at implementing aid for women in distress by inviting everyone to participate. They argue that they are particularly suited to this task because of their gender. Thus, the gap between a liberal Islam of converts, on the one hand, and a cultural and patriarchal Islam, on the other hand, which allegedly dominates Pakistani society, is taking shape. The most militant converts ground their arguments on the one hand on their voluntary activities in the name of Islam and on the other hand on the discourse of Ahmadiyya that upholds the importance of the education (religious and scientific) of girls and their professionalization. This official discourse advocates the professionalization of women when the profession does not hinder family life and the education of 
children for whom the woman is held responsible. ${ }^{12}$ The social commitment of converts within the framework of the NGO, founded by a khalifa of the Ahmadiyya and therefore recognized and respected by the whole community, introduces new dynamics within the group, where relations between converts and non-converts are renegotiated. ${ }^{13}$

The liberating power of Ahmadi Islam for women compared to a "traditional" Islam perceived as patriarchal is also regularly named by the converts I met in Burkina Faso. In particular, they point to the fact that the vast majority of Ahmadi men are married to only one woman, although Islam allows them to take four wives. One of the converts, recently married, born into a practising Muslim family and converted to Ahmadi Islam two years ago, elicits this idea: "You know, any woman would like to be alone in her home. Now, if he tells me his reasons for taking a second wife, and they are valid, I would not object. If not, it would be against the prescriptions of the Koran. But at least, with the jama'at, I have been told what the valid reasons are. Today, it is still difficult to justify taking two, three, or four wives. In any case, I would know how to argue." The involvement of women in Ahmadi Islam and the issues of polygamy and women's rights in general are a way for them to question the reading of Islam in which the tradition inherited by their fathers endeavoured to confine them. By also drawing on Islam or seeking support from the Koran, they allow themselves to follow a line of reasoning that is more in line with their interests (Timera 1997).

In Burkina Faso, contrary to France, most of Humanity First's activities are located in rural areas. However, when there is an emergency such as in the case of the 2009 floods in Ouagadougou, the Covid-19 health crisis, or when a particular request is made, the NGO also launch operations in the city. The intervention in which I participated in the central prison of Ouagadougou (Maco) was initiated by a request addressed to the doctor of the Ahmadi hospital.

"Five of us are leaving for Maco. The Doctor, the driver, the doctor's assistant, one of the Ahmadiyya students staying at the mission who is a volunteer for Humanity First, and me. Before starting the car, the doctor pronounces a short prayer to call on Allah's mercy. He explains to me that he does not undertake any medical or social action without first praying. The trunk is full of medicines. We make our way into the courtyard of Maco very easily and carry our medicines to the inner courtyard of the male inmates. Dozens of them line up behind the table set up by the doctor. He asks: where does it hurt? in your head, ok give him paracetamol. In the belly, okay, give him an antiseptic. Sometimes, when we can see from the patient's face that he didn't understand what the doctor says, Issa translates it into Moore, sometimes into Fulfulde. The head of the medical staff of Maco attends the scene without intervening. He beckons me not to leave the table. A prisoner comes up, asking in perfect French for glasses. The doctor advises him to go and see the Protestants next time they visit Maco. He considers they can offer ophthalmological care. He notes on a sheet of paper the names of the patients in need of cataract surgery. He turns to the head of staff: "We will soon have cataract specialists at the Centre. Maybe these people could benefit from our free operations?" One hour later, the drugs have all been distributed and we're on our way. In the car, the doctor asks Issa how many cards he has distributed. They draw up their statistics by means of these cards. Today he distributed 200. The doctor speaks to the Humanity First student and says: "'You can write this down in your report. I'll give you more details at the office'" (Ouagadougou, November 2011).

Unlike food distribution in Paris where all participants are volunteers, medicine distribution in Ouagadougou also includes two hospital employees who get paid. In both cases, social action takes place after spiritual exercises. In particular, prayer serves as a support for commitment. Pleasing God and being faithful to Islam are motivations clearly or implicitly mentioned by the actors. Social action

12 A high percentage of Ahmadi girls have earned university degrees, particularly in England and Germany, where the majority of them still originate from the Pakistani immigrant community. The local Education (Ta'lim) Department of every Jama'at supervises the academic progression of each member, organizes students counselling, religious classes and education seminars which provide guidance for pupils and their parents.

13 On the dynamics of change that converts bring to a religious group see (Setta 1999; Allievi 1999; Kepel 1991). 
is elevated to the rank of religious practice. An important goal that motivates social commitment is seeking God's favour, as much for the doctor as for the French volunteers. Assistance to the poor and the marginalized populations give the opportunity to perfect one's spiritual progress. Psychological factors, such as feeling good when helping others and feeling guilty when not helping others, are often named as determinants for one's involvement in charitable work.

Everywhere, Humanity First defends the impartiality of its action for the benefit of all people in need, the same way public institutions operate. In practice, whether in Burkina Faso or in France, people in need often have a link with volunteers, with their interests and constraints. This was the case for choosing retirement homes in the Ile de France region, which was based on personal acquaintances of the managers or animators with some of the NGO's activists. Similarly, the intervention at Maco in Ouagadougou was organized because the doctor and the head of the medical staff of the prison knew each other. The medical camps set up by Humanity First in the villages of Burkina Faso are always carried out by means of the Ahmadiyya missionaries who are in charge of the area concerned. Personal links can also be made through social networks, as they act as a relay between people in need and those willing to support them. As a result, the case of a person in need is presented to the group, which then seeks to establish a direct link with that person. After discussing the case, the group decides whether or not to support the person morally or materially. During the lockdown in France this was a common modus operandi.

During the activities in Ouagadougou and Paris, the collaboration between members of Humanity First and those of other faith-based or public organizations has developed. In a difficult religious context, as it is the case in Burkina Faso since the terrorist attacks of 2016, inter-religious relations are particularly underscored in the media and their "dialogue" is valued. ${ }^{14}$ Ahmadiyya has a long tradition of theological debate with representatives of different religions (Langewiesche 2020a). Humanity First puts these theological aspirations into practice by seeking concrete collaboration with NGOs of different faiths. For example, in Burkina Faso Humanity First is associated with one-dollar-glasses, a secular NGO and the Ministry of Health for healthcare actions. If such cooperation is carried out with lay, Catholic, or Protestant structures, collaborating with Muslim associations is more complicated due to the outsider position of Ahmadiyya. The openness towards other religions is one of their features that attracted Ibrahim both to Ahmadi Islam and to Humanity First.

Ibrahim came to know the Ahmadiyya Muslim Community of Burkina Faso through his uncle, with whom he grew up in a town in northern Burkina Faso. He accompanied his uncle to jama'at meetings and ceremonies. At the age of 19 , he decided to sign the bai'hat and soon afterwards to get involved in the Ahmadiyya youth section. He presents his conversion as a combination of an emotional reaction to thank his uncle and mentor, to whom he owes his education, with a rational decision after reading the founding texts of Ahmadiyya. It is the convincing logic and scientificity of Ahmadiyya's interpretations, the rationality of the Koran, the direct access to God and the centrality of the kalifate guaranteeing a clear and comforting path that attracted him. Although he was socialized in his uncle's Ahmadiyya family and gradually acquired the Ahmadiyya habitus, he describes his personal decision as decisive to join the Ahmadiyya community. During his schooling, Ibrahim had his first experience with associations by becoming an activist for the local Amnesty International group. After integrating Ahmadiyya, he chose to get involved with Humanity First. As a student at the University of Ouagadougou, he was welcomed at the mission benefitted from the support of the missionaries: "that's how it is in the jama'at, we don't leave Ahmadiyya children alone in a big city." Today, engaged in a long academic career in parallel to a professional work in an international NGO, he is still available for activities with the jama'at and assume responsibilities within Humanity First. He is now married to his girlfriend who was involved in the AEEMB, the association of Muslim pupils

14 A press review from 2010 to 2017 revealed that articles on inter-religious dialogue in the national press increased along the year 2014 marked by political tensions and insurgency, as well as in 2017 with the resurgence of terrorist attacks (Revue de presse 2018, p. 16). 
and students in Burkina Faso. During the years they spent together, she in turn became involved in Ahmadiyya, although she remained vigilant on certain issues.

Not surprisingly, Ibrahim, like other students, gains from social engagement the opportunity for developing skills or exercising responsibilities that are more difficult to acquire and exercise elsewhere. Engaging in humanitarian work as a springboard for employment is an important motivation for many young people. Ibrahim's story also shows the importance of the Ahmadiyya networks that he accessed after he integrated the movement. Feelings of solidarity and trust within the community motivate wealthy members to support their brothers, while needy or younger members of the group benefit from access to the services and goods made possible by the network, such as access to housing for Ahmadiyya students in Ouagadougou, assistance to find internships, or to join professional networks. In addition to sub-organizations by age and gender groups, there are associations within Ahmadiyya by profession. For example, the International Association of Ahmadiyya Architects and Engineers (IAAAE), the Association of Ahmadiyya Political Scientists and Lawyers, or the Association of Ahmadiyya Muslim Teachers (AMTA). These associations have an international dimension and are of particular interest to young Ahmadis at the beginning of their careers.

Humanity First's Burkinabe volunteers, current or former students, often explain their motivations for their involvement in Humanity First with the desire to serve the community by means of their professional knowledge, to thank the jama'at for the help they themselves received, and to actively participate in societal change. In Burkina Faso, where even after the political transition in 2015, ${ }^{15}$ expectations for improved living conditions are not being met by the new government, or are only being implemented partially and very slowly, civil society organizations such as Humanity First are seen as an opportunity to advocate change (Hagberg et al. 2017). One of the Ahmadiyya students interviewed in 2017 put it this way:

«On a marché ! On a marché fatigué ! Maintenant l'espoir est parti. En tout cas, tout seul tu ne peux rien faire. Il te faut un groupe fort qui te soutient, comme l'Ahmadiyya et qui est actif comme Humanity First. C'est comme ça que ça va bouger!»

“We walked! We walked ourselves tired! Now the hope has gone. Anyway, you can't do anything on your own. You need a strong group that supports you, like Ahmadiyya and an active active like Humanity First. That's how things will improve!"

Indeed, many observers have noted the involvement of youth in the popular uprising and of civil society organizations calling for political change and the improvement in the education and training system.

Motivations for becoming involved with Humanity First vary in France and Burkina Faso depending on the socio-political situation in the country and the personal situation of the volunteers, while the religious motive is a constant and driving force that leads to a multitude of other motives. Being involved in an NGO based on the values of Islam becomes a means of promoting compassion as another way of living one's faith, a message that aims to make citizens aware of a life based on helping others, active solidarity that expresses the fact that faith is not only to be found in the mosques.

These two individual stories, chosen to highlight trends observed throughout the data set, indicate that social engagement is presented as an adjustment between a personal story and a faith-based organization. In the profile of activists, we find people who want to "go into politics" without joining a party; who want "professional training" without enrolling in university studies; who want to "fight for women's rights" without participating in feminist networks.

The two social work actions described above and the life-stories of the converts show that the relationship with the group is structural in terms of social and religious commitment. It is precisely the centralized nature of the Ahmadi kaliphate and the transnational dimension of Humanity First that

15 Burkina Faso has in fact experienced two transitions: from 1 to 18 November 2014 under Zida and from 18 November 2014 to 28 December 2015 under Kafando. 
converts seem to value for their personal fulfilment; a strong communal and transnational construction in a society of individuals. Or, to put it another way, the combination of an individual dimension with a strong communitarian aspect.

However, beyond this accommodation between social and religious commitment, beyond the adjustment between individual aspirations and a structured and centralized religious organization, should we not detect in the facts described here emerging forms of commitment through modalities of solidarity that intersect local action of proximity with membership in transnational networks?

Affiliation to an international network is decisive for each local Humanity First group in order to carry out successful local actions. Membership in the Ahmadiyya community and Humanity First International allows for the rapid mobilization of resources far beyond local capacity and of volunteers who act collectively. The international networks allow local committees to benefit from global technical expertise and media coverage in newspapers and Ahmadiyya's own media (radio and television). By contrast, local Humanity First groups, and especially converts, bring into the international movement their specific needs related to the particular contexts in each country and their status as converts.

\section{Conclusions}

The central idea developed along this article has been to explore links between religious conversion and social engagement. In order to grasp these articulations, I drew on interviews and observations of Ahmadi converts to Islam engaged in humanitarian actions in France and Burkina Faso. Putting the observations made during social interventions into perspective with individual life stories makes it possible to reconstruct the plurality of commitments and the construction of multiple identities. What allows a commitment or a conversion to materialize and be maintained is certainly a matter of individual choices, which are based on a singular biographical trajectory, but it is just as much a matter of the historical, social, or religious contexts in which these motivations are grounded to reach fulfilment. The different dimensions that give meaning to a commitment in an association of solidarity and to conversion sometimes overlap: serving others, ensuring one's spiritual advancement, and making sense of one's individual history as a woman-or, as a young person in search of a job or seeking political participation. Converts must use various strategies of recognition, either as individuals or as a group, which place them in a permanent negotiation with those around them. They negotiate their place with the Pakistani majority within the movement, with other Muslim currents in the country or with the secular state.

Reading conversion as negotiation allows us to understand why converts, accustomed to the recognition of otherness through their own experience as converts, become involved in civil commitments that require recognition of the value of marginalised or vulnerable people, and in a broader sense to accept the other in his or her otherness. The point is not to propose a universal theory of conversion, but to adapt the conceptual approach to a religious movement that stands out for its idiosyncratic, minority status, and with a strong communitarian tendency. Combining the two notions of conversion and negotiation allows in this precise context to refine perspectives on the civil activities of converts. Negotiation is the link that highlights an elective affinity between the intimate experience of conversion and social commitment to the other in the public space. My purpose is to underline the reciprocal fruitfulness of two notions for understanding the specificity of the status of converts in relation to other actors engaged in civil activities and, at the same time, to specify the position of converts within the religious group they join. Conversion to a minority Muslim movement, such as Ahmadiyya, raises particular issues because members of a minority have different priorities from those of the religious majority, especially in terms of recognition. In France, the Ahmadiyya Muslim community faces a two-fold minority situation, within Islam and within a Christian majority. In Burkina Faso and France, a third minority situation adds up, as they constitute a minority within the movement itself. 
In France, where the Ahmadi community is still relatively small, involvement in the NGO enables some of the converts to assert themselves in relation to the prevailing Pakistani Ahmadis. The commitment within a humanitarian organization founded by the Ahmadiyya leader seems to them more adapted to show and practise the "true face" of Islam detached from Pakistani culture and to combine religious and social commitment.

In Burkina Faso, involvement in the NGO allows converts to connect their personal and professional aspirations to an engagement for the development of the country and in favour of vulnerable populations, sometimes coupled with political activism.

For a religious minority, participation in development and solidarity networks can be a means for establishing itself as a legitimate and valuable member of society, so that potential converts can be solicited according to their personal priorities within a pluralistic religious landscape. Social actions in the public sphere make it possible to initiate a real reflection on the place and role of a minority religion that asserts itself in France and Burkina Faso as a social actor, without having any official recognition from the umma.

Funding: The data for this article was collected along different research projects funded by the German Research Foundation (DFG), grant number LA 2772/3-1, the Gerda Henkel Foundation, grant number AZ 04/IS/13, and the Bureau Central des Cultes, French Ministry of Interior, grant number n ${ }^{\circ}$ 41/2019.

Acknowledgments: I am grateful to many Ahmadis in Germany, France, Burkina Faso, Benin, and Ghana, and particularly to the Humanity First teams in France and Germany for the time that they devoted to my enquiry and for their kindness in answering all my questions. I thank Adjara Konkobo for the transcriptions of the recorded interviews. Sébastien Le Pipec polished my very German formulations into proper English and never hesitated to offer insightful suggestions. Finally, I am particularly indebted to Mahamadi Ouédraogo for his invaluable assistance and active interest in my field research in Burkina Faso.

Conflicts of Interest: The author declares no conflict of interest. The funders had no role in the design of the study; in the collection, analyses, or interpretation of data; in the writing of the manuscript, or in the decision to publish the results.

\section{References}

Adams, Vincanne. 2013. Markets of Sorrow, Labors of Faith: New Orleans in the Wake of Katrina. Durham: Duke University Press.

Ahmed, Munir D. 2012. Studien zur Ahmadiyya. Ein Fall Religiöser Diskriminierung in Pakistan. Leipzig: Fazli Books. Allahayari, Rebecca Anne. 2000. Visions of Charity. Berkeley: University of California Press.

Allievi, Stefano. 1999. Pour une sociologie des conversions: Lorsque des Européens deviennent musulmans. Social Compass 46: 283-301. [CrossRef]

Audet Gosselin, Louis, and Kathéry Couillard. 2019. ONG confessionnelles au Burkina Faso. In Rencontres Religieuses et Dynamiques Sociales au Burkina Faso. Edited by Alice Degorce, Ludovic Kibora and Katrin Langewiesche. Dakar: Editions Amalion, pp. 225-45.

Balzani, Marzia. 2010. Dreaming, Islam and the Ahmadiyya Muslims in the UK. History and Anthropology 21: 293-305. [CrossRef]

Beckford, James A. 1989. Religion and Advanced Industrial Society. London and Boston: Unwin Hyman.

Benthall, Jonathan, and Jérôme Bellion-Jourdan. 2003. The Charitable Crescent. Politics of Aid in the Muslim World. London: Tauris.

Benthall, Jonathan. 2005. L'humanitarisme islamique. Cultures et Conflits 60: 103-22. [CrossRef]

Bertaux, Daniel. 1980. L'approche biographique: Sa validité méthodologique, ses potentialités. Cahiers Internationaux de Sociologie 69: 197-225.

Blakely, Thomas D., Walter E. A. Van Beek, and Dennis L. Thomson, eds. 1994. Religion in Africa. London: James Curry.

Bornstein, Erica. 2003. The Spirit of Development: Protestant NGOs, Morality, and Economics in Zimbabrwe. New York and London: Routledge.

Bouzar, Dounia. 2001. L'islam des Banlieues. Les Prédicateurs Musulmans: Nouveaux Travailleurs Sociaux? Paris: Éditions Syros. 
Brodard, Baptiste. 2011. De L'inscription Communautaire à L'affirmation sur la Scène Sociale. L'action Sociale Musulmane en Région Parisienne. Master's thesis, Faculté des Lettres de l'Université de Fribourg, Fribourg, Switzerland.

Casanova, José. 1994. Public Religions in the Modern World. Chicago: University of Chicago Press.

Cissé, Issa, and Katrin Langewiesche. 2019. L'Association Islamique Ahmadiyya au Burkina Faso. In Rencontres Religieuses et Dynamiques Sociales au Burkina Faso. Edited by Kibora Degorce, Ludovic Ouhonyioué Kibora and Katrin Langewiesche. Dakar: Editions Amalion, pp. 90-107.

Coleman, Simon. 2000. The Globalisation of Charismatic Christianity: Spreading the Gospel of Prosperity. Cambridge: Cambridge University Press.

Comaroff, Jean, and John L. Comaroff. 1991. Of Revolution and Revelation. Christianity, Colonisation and Consciousness in South Africa. Chicago and London: University of Chicago Press.

de Terssac, Gilbert. 2003. La théorie de la Régulation Sociale de Jean-Daniel Reynaud. Paris: La Découverte.

Diop, Moustapha. 1989. Immigration et religion: Les musulmans négro-africains en France. Migration Société I: 45-57.

Duclos, Bénédicte Harvard, and Sandrine Nicourd. 2005. Pourquoi s'engager? Bénévoles et Militants dans les Associations de Solidarité. Paris: Payot.

Ewing, Katherine Pratt. 2015. 'Islam Is Not a Culture': Reshaping Muslim Publics for a Secular World. In Religion in Diaspora: Cultures of Citizenship. Edited by Sondra L. Hausner and Jane Garnett. London: Palgrave Macmillan, pp. 202-25.

Freeman, Deena. 2012. Pentecostalism and Development Churches, NGOs and Social Change in Africa. New York: Palgrave Macmillan.

Frégosi, Franck. 2009. Formes de mobilisation collective des musulmans en France et en Europe. Revue Internationale de Politique Comparée 16: 41-61.

Galonnier, Juliette, Amélie Puzenat, Hamzi Khateb, and Géraldine Mossière. 2019. Introduction: Conversions à l'islam. Archives de Sciences Sociales des Religions 186: 11-31.

Gifford, Paul. 2004. Ghana's New Christianity. In Pentecostalism in a Globalising African Economy. London: Hurst.

Gifford, Paul. 2015. Christianity, Development and Modernity in Africa. London: Hurst.

Habermas, Jürgen. 1992. "L'espace public", 30 ans après. Quaderni 18: 161-91. [CrossRef]

Hagberg, Sten, Ludovic Kibora, Sidi Barry, Siaka Gnessi, and Adjara Konkobo. 2017. Transformations Sociopolitiques Burkinabè de 2014 à 2016. Africa Studies. Uppsala: Uppsala University.

Hanson, John H. 2017. The Ahmadiyya in the Gold Coast: Muslim Cosmopolitans in the British Empire. Bloomington: Indiana University Press.

Hefner, Robert W., ed. 1993. Conversion to Christianity. Oxford: University of California Press.

Hervieu-Léger, Danièle. 1999. Le Pèlerin et le Converti. La Religion en Mouvement. Paris: Flammarion.

Holder, Gilles, ed. 2009. L'Islam en Afrique: Vers un Espace Public Religieux? Paris: Karthala.

Jonathan, Laurence, and Juston Vaïsse. 2007. Intégrer l'Islam. Paris: Odile Jacob.

Jonker, Gerdien. 2016. The Ahmadiyya Quest for Religious Progress: Missionizing Europe 1900-1965. Leiden: Brill.

Jules-Rosette, Benetta. 1975. African Apostles: Ritual and Conversion in the Church of John Maranke. Ithaca: Cornell University Press.

Kepel, Gilles. 1991. La revanche de Dieu: Chrétiens, juifs et musulmans à la reconquête du monde. Paris: Éditions du Seuil.

Keynote address at the International Conference of Humanity First in the Baitul Futuh Mosque (UK). 2015. Available online: https://www.khalifatulmasih.org/press-releases/head-ahmadiyya-muslim-communityaddresses-humanity-first-international-conference/ (accessed on 23 May 2020).

Kroessin, Mohamed Ralf. 2009. Mapping UK Muslim Development NGOs. Working Paper 30. Birmingham: University Birmingham.

Lahlou, Rachid. 2018. Un Humanitaire Musulman dans la République. Paris: Ateliers Henry Dougier.

Langewiesche, Katrin. 1998. Des conversions réversibles: Études de cas dans le nord-ouest du Burkina Faso. Parcours de conversion. Journal des Africanistes 68: 47-65. [CrossRef]

Langewiesche, Katrin. 2003. Mobilité Religieuse. Changements Religieux au Burkina Faso. Hamburg, Berlin and Münster: LIT-Verlag. 
Langewiesche, Katrin. 2011. Konfessionell, national, global: Das Gesundheitswesen in Burkina Faso aus historischer Perspektive. In Auf dem Boden der Tatsachen. Festschrift für Thomas Bierschenk. Edited by Nikolaus Schareika, Eva Spies and Pierre-Yves Le Meur. Köln: Rüdiger Köppe Verlag, pp. 415-34.

Langewiesche, Katrin. 2020a. Le calife et son portrait. L'iconographie d'un Islam missionnaire. In Matérialités Religieuses. Aux frontières du Public et du Privé. Edited by Ba Mame-Penda, Saint-Lary Maud and Samson Fabienne. Dakar: édition Codesria, forthcoming.

Langewiesche, Katrin. 2020b. Ahmadiyya and development aid in West Africa. In Does Religion make a Difference? Religious NGOs in International Development Collaboration. Edited by Andreas Heuser and Jens Köhrsen. Baden-Baden: Nomos, pp. 263-86.

Langewiesche, Katrin. 2020c. Politics of Humanitarianism. The Ahmadiyya and the provision of Social Welfare. In Muslim Faith-Based Organizations and Social Welfare in Africa. Edited by Holger Weiss. London: Palgrave Macmillan, forthcoming.

Lathan, Andrea. 2008. The Relativity of Categorizing in the Context of the Ahmadiyya. Welt des Islams 48: 372-93. [CrossRef]

Lathan, Andrea. 2010. Reform, Glauben und Entwicklung: Die Herausforderungen für die Ahmadiyya-Gemeinde. In Islam in Europa: Religiöses Leben Heute. Ein Portrait Ausgewählter Islamischer Gruppen und Institutionen. Edited by Dietrich Reetz. Münster: Waxmann, pp. 79-107.

Le Pape, Loïc. 2007. Engagement religieux, engagements politiques. Archives de Sciences Sociales des Religions 140: 9-27. [CrossRef]

LeBlanc, Marie Nathalie. 2012. Du militant à l'entrepreneur: Les nouveaux acteurs religieux de la moralisation par le bas en Côte d'Ivoire. Cahiers d'études Africaines 206-207: 493-516. [CrossRef]

Lofland, John, and Rodney Stark. 1965. Becoming a world-saver: A theory of conversion to a deviant perspective. American Sociological Review 30: 862-74. [CrossRef] [PubMed]

Martens, Silvia. 2014. Muslim Charity in a Non-Muslim Society. Journal of Muslims in Europe 3: 94-116. [CrossRef]

Mary, André. 1998. Retour sur la conversion africaine: A propos de Horton, Peel et les autres. Journal des Africanistes 68: 11-20. [CrossRef]

Meintel, Deirdre. 2003. La stabilité dans le flou: Parcours religieux et identité de spiritualistes. Anthropologie et Sociétés 27: 35-64. [CrossRef]

Minahan, James. 2002. Encyclopedia of the Stateless Nations. Ethnic and National Groups Around the World. Vol I. London: Greenwood Press.

Molokotos-Liederman, Lina, Anders Bäckström, and Grace Davie, eds. 2018. Religion and Welfare in Europe. Gendered and Minority Perspectives. Bristol: Policy Press.

Mossière, Géraldine. 2009. Des femmes converties à l'islam en France et au Québec: Religiosités d'un nouveau genre. Ph.D. dissertation, University of Montréal, Montréal, QC, Canada.

Ozkan, Mehmet. 2012. Transnational Islam, Immigrant NGOs and Poverty Alleviation: The Case of the IGMG. Journal of International Development 24: 467-84. [CrossRef]

Peel, John D. Y. 1990. The pastor and the babalawo: The interaction of religions in nineteenth-century Yorubaland. Africa 60: 338-69. [CrossRef]

Petersen, Marie-Juul. 2015. For Humanity or for the Ummah: Aid and Islam in Transnational Muslim NGOs. London: Hurst.

Pilon, Marc, Alice Degorce, and Katrin Langewiesche. 2019. Les enjeux des chiffres: La démographie des religions au Burkina Faso. In Rencontres Religieuses et Dynamiques Sociales au Burkina Faso. Edited by Kibora Degorce, Ludovic Ouhonyioué Kibora and Katrin Langewiesche. Dakar: Editions Amalion, pp. 165-95.

Poirier, Jean. Simone Clapier-Valladon, and Paul Raybaut. 1983. Les Récits de vie. Théorie et Pratique. Paris: PUF.

Revue de presse. 2018. La Perception du Religieux au Burkina Faso à Travers des Articles de Presse (2010-2017). Programme «État des lieux des Connaissances sur les Religions au Burkina Faso», Document de Travail. Ouagadougou: IRD.

Quiminal, Catherine, and Mahamet Timéra. 2002. 1974-2002, les mutations de l'immigration ouest-africaine. Hommes et Migrations 1239: 19-32. [CrossRef]

Sadouni, Samadia. 2009. Humanisme spiritual et ONG islamiques. Afrique Contemporaine 231: 155-70. [CrossRef]

Salvatore, Armando. 2005. Making Public Space: Opportunities and Limits of Collective Action among Muslims in Europe. Journal of Ethnic and Migration Studies 30: 1013-31. [CrossRef] 
Savadogo, Mathias, Muriel Gomez-Perez, and Marie Nathalie LeBlanc. 2016. Reflections on the Socio-political Roles of Islamic NGOs in West Africa: Senegal, Côte d'Ivoire and Burkina Faso. In Faith and Charity. Religion and Humanitarian Assistance in West Africa. Edited by Marie Nathalie LeBlanc and Louis Audet Gosselin. London: Pluto Press, pp. 27-46.

Schurmans, Marie-Noëlle. 2013. Négociations et transactions: Un fondement socio-anthropologique partagé. Négociations 20: 81-93. [CrossRef]

Setta, El-Houari. 1999. Le Suisse converti à l'islam: émergence d'un nouvel acteur social. Social Compass 46: 337-49. [CrossRef]

Skinner, David E. 2010. Da'wa and Politics in West Africa: Muslim Jama'at and Non-Governmental Organisations in Ghana, Sierra Leone and the Gambia. In Development and Politics from Below: Exploring Religious Spaces in the African State. Edited by Barbara Bompani and Maria Frahm-Arp. London: Palgrave, pp. 99-130.

Snow, David A., and Cynthia L. Phillips. 1980. The Lofland-Stark Conversion Model: A Critical Reassessment. Social Problems 27: 430-47. [CrossRef]

Soares, Benjamin, and Marie Nathalie LeBlanc. 2015. Islam, jeunesse et les trajectoires de mobilisation en Afrique de l'Ouest dans l'ère néolibérale: Regard anthropologique. In Mobilisations Collectives en Afrique. Edited by Kadja Tall. Leiden: Brill, pp. 67-90.

Sounaye, Abdoulaye. 2011. Doing Development the Islamic Way in Contemporary Niger. Bulletin de l'APAD 33: 61-90.

Thelen, Tatjana, Caroline Lautloff-Grandits, and Anja Peleikis. 2009. Social Security in Religious Networks. An Introduction. In Social Security in Religious Networks. Edited by Caroline Lautloff-Grandits, Anja Peleikis and Tatjana Thelen. New York: Berghahn Books, pp. 1-15.

Thuderoz, Christian. 2009. Régimes et registres de négociation. Négociations 2: 107-18. [CrossRef]

Timera, Mahamet. 1997. Les associations de femmes africaines: Un creuset d'intégration. Revue Française des Affaires Sociales 2: 159-65.

Van Der Veer, Peter. 1996. Conversion to Modernities. The Globalisation of Christianity. London: Routledge.

Vitale, Mara. 2019. L'islam confrérique de la tijâniyya et l'hamawiyya. In Rencontres Religieuses et Dynamiques Sociales au Burkina Faso. Edited by Kibora Degorce, Ludovic Ouhonyioué Kibora and Katrin Langewiesche. Dakar: Editions Amalion, pp. 41-55.

Weiss, Holger, ed. 2020. Muslim Faith-Based Organizations and Social Welfare in Africa. New York: Palgrave Macmillan.

Wohlrab-Sahr, Monika. 1999. Konversionen zum Islam in Deutschland und den USA. Frankfurt and New York: Campus Verlag.

(C) 2020 by the author. Licensee MDPI, Basel, Switzerland. This article is an open access article distributed under the terms and conditions of the Creative Commons Attribution (CC BY) license (http://creativecommons.org/licenses/by/4.0/). 

MDPI

St. Alban-Anlage 66

4052 Basel

Switzerland

Tel. +41 616837734

Fax +41 613028918

www.mdpi.com

Religions Editorial Office

E-mail: religions@mdpi.com

www.mdpi.com/journal/religions

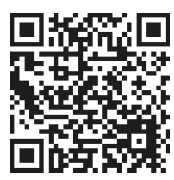



MDPI

St. Alban-Anlage 66

4052 Basel

Switzerland

Tel: +41 616837734

Fax: +41 613028918

www.mdpi.com 